\title{
Kartierung von umhüllungsrelevanten Aminosäureresten auf dem Hepatitis B Virus Kapsid
}

\author{
Dissertation \\ zur Erlangung des Doktorgrades \\ der Mathematisch-Naturwissenschaftlichen Fakultäten \\ der Georg-August-Universität zu Göttingen
}

vorgelegt von

Dirk Ponsel

aus Coburg

Göttingen 2003 
D7

Referent:

Prof. Dr. G. Gottschalk

Korreferent:

PD Dr. H. Kolmar

Tag der mündlichen Prüfung: $\quad$ 05.11.2003 


\section{INHALTSVERZEICHNIS}

1 EINLEITUNG 1

1.1 Überblick 1

1.2 Das Hepatitis-B-Virus-Genom 2

1.3 Genprodukte und Virusstruktur 4

$\begin{array}{lll}1.4 & \text { Virusreplikation } & 7\end{array}$

$1.5 \quad$ Infektionszyklus des Hepatitis-B-Virus 8

$\begin{array}{lll}1.6 & 10\end{array}$

$\begin{array}{lll}1.7 & \text { Ziel der Arbeit } & 14\end{array}$

2 MATERIAL 16

$\begin{array}{lll}2.1 & \text { Bakterienstamm } & 16\end{array}$

2.2 Zelllinien 16

$\begin{array}{ll}2.3 & 17\end{array}$

$\begin{array}{lll}\text { 2.3.1 Medien zur Anzucht von E. coli } & 17\end{array}$

$\begin{array}{lll}\text { 2.3.2 Nährmedien zur Kultivierung von Zellkulturen } & 17\end{array}$

$\begin{array}{lll}2.4 & \text { Enzyme } & 18\end{array}$

$\begin{array}{lll}2.5 & \text { Plasmide } & 19\end{array}$

2.6 Oligonukleotide 26

$2.7 \quad$ Antikörper 28

2.8 DNA-Längenstandards 29

2.9 Radionuklide 30

$2.10 \quad$ Lösungen und Puffer 30

$2.11 \quad$ Laborgeräte und Materialien 33

2.12 Chemikalien 36 
3.1 Molekularbiologische Methoden 37

3.1.1 Vorbereitung von Lösungen und Arbeitsgeräten 37

3.1.2 DNA-Arbeiten mit Enzymen 37

3.1.2.1 Polymerase-Kettenreaktion (SAIKI et al., 1985) 37

3.1.2.2 Spaltung von DNA mit Hilfe von Restriktionsendonukleasen 39

3.1.2.3 Ligation von DNA-Fragmenten 40

3.1.2.4 Auffüllen von überhängenden DNA-Enden 40

3.1.3 DNA-Präparation aus E. coli 41

3.1.3.1 Isolierung von Plasmid-DNA im analytischen Maßstab (alkalische Lyse nach BIRNBOIM und DOLY, 1979 modifiziert)

3.1.3.2 Isolierung von Plasmid-DNA im analytischen Maßstab unter Verwendung des Qiagen-Mini-Spin-Plasmid-Prep-Kit

3.1.3.3 Isolierung von Plasmid-DNA im präparativen Maßstab (alkalische Lyse nach BIRNBOIM und DOLY, 1979 modifiziert)

3.1.3.4 Isolierung von Plasmid-DNA im präparativen Maßstab unter Verwendung des Qiagen-Plasmid-Maxi-Prep-Kit

3.1.4 Reinigung und Konzentrierung von DNA 44

3.1.4.1 Phenol/Chloroform-Extraktion 44

3.1.4.2 Ethanol-Fällung von DNA-Lösungen 44

3.1.4.3 Isopropanol-Fällung von DNA-Lösungen 45

3.1.4.4 Isolierung von DNA aus Agarosegelen mit dem

Qiagen-Gel-Extraction-Kit

3.1.4.5 Konzentrationsbestimmung von DNA-Lösungen 45

3.1.4.6 DNA-Elektrophorese im Agarosegel 46

3.1.5 Automatische DNA-Sequenzierung am ABI 373 DNA-Sequenzer (Applied Biosystems, Weiterstadt) 47

3.1.6 DNA-Nachweismethoden 48

3.1.6.1 Southern-Blot (SOUTHERN, 1975) 48

3.1.6.1.1 DNA-Transfer auf eine Nylonmembran 49

$\begin{array}{ll}\text { 3.1.6.1.2 } & \text { Markierung der Sonde mit alkalischer Phosphatase } \\ \text { und Hybridisierung } & 49\end{array}$

3.1.6.1.3 Nachweis der Sonde 49

3.1.6.2 Nachweis von HBV-ccc-DNA mittels Endogener
Polymerase-Reaktion 
3.1.6.3 Aufreinigung von Nukleokapsiden und Virionen zur viralen DNA-Isolierung

3.1.6.4 HBV-Nachweis mittels PCR 52

3.1.7 Direkte Klonierung von PCR-Produkten mit dem TA-Cloning-Kit (Invitrogen) 53

3.1.8 Arbeiten mit Proteinen $\quad 54$

3.1.8.1 Immunpräzipitation $\quad 54$

3.1.8.2 SDS-Polyacrylamid-Gelelektrophorese 54

3.1.8.3 Comassiefärbung von Polyacrylamidgelen 56

3.1.8.4 PEG-Fällung von HBV Kapsiden 56

3.1.8.5 Western-Blot von Coreprotein unter nativen Bedingungen 57

3.1.8.6 Immunblot 57

3.1.9 Autoradiographie 58

3.1.10 Isolierung von mRNA mittels Oligotex-direct-mRNA-Kit (Qiagen) 59

3.1.11 cDNA-Synthese und PCR-Amplifikation mit dem

ONE-STEP-RT-PCR Kit (Gibco BRL, Eggestein) 59

3.2 Mikrobiologische Methoden 59

3.2.1 Arbeiten und Umgang mit Bakterien $\quad 59$

3.2.1.1 Stammhaltung 59

3.2.1.2 Vermehrung von E. coli-Bakterien $\quad 60$

$\begin{array}{lll}\text { 3.2.1.3 Bestimmung der Zelldichte } & 60\end{array}$

3.2.2 Herstellung kompetenter E. coli-Bakterien 60

3.2.3 Transformation von E. coli-Bakterien durch Hitzeschock 61

3.2.4 Vereinzelung von E. coli-Bakterien $\quad 61$

$3.3 \quad$ Arbeiten mit Zellkulturen $\quad 62$

3.3.1 Kultivierung von Säugerzellen $\quad 62$

3.3.2 Transfektion von HuH7- und HepG2-Zellen mit
Calciumphospatpräzipitaten

3.3.3 Transfektion von COS7-Zellen mit DEAE-Dextran/Chloroquine 63

3.3.4 Einfrieren und Auftauen von Säugerzellen 63

3.3.5 Bestimmung von HBsAg und HBeAg 64

3.3.6 Zelllysatherstellung 64

3.3.7 Fixierung von Zellen für Immunfluoreszenzuntersuchungen 64

3.3.8 Inkubation von Zellkulturen mit HBV-Virionen 66 
3.3.8.1 HBV-Bindungsassay $\quad 66$

3.3.8.2 HBV-Aufnahmeassay 66

3.3.8.3 Aufarbeitung der Proben 66

3.3.9 Metabolische pulse/chase-Markierung in Zellkulturen 67

$\begin{array}{lll}4 & \text { ERGEBNISSE } & 68\end{array}$

4.1 Kartierung umhüllungsrelevanter Aminosäureseitenketten auf der HBV-Kapsidoberfläche 68

4.1.1 Auswahl der Mutationen mit Hilfe der kristallographischen Daten $\begin{array}{ll}\text { des Coreproteins } & 69\end{array}$

4.1.2 Herstellung der Coremutanten 77

4.1.3 Test der Coremutanten auf Umhüllungskompetenz 81

4.1.4 Analyse der Spitze des Spikes - Herstellung und $\begin{array}{ll}\text { Testung von zwei Dreifachmutanten } & 89\end{array}$

4.1.5 Untersuchung der EPR-negativen Coremutanten 92

4.1.5.1 Nachweis assemblierter Kapside durch PEG-Fällung

4.1.5.2 Nachweis DNA-enthaltender Nukleokapside durch Southern-Blot nach Immunpräzipitation $\quad 95$

4.2 Klonierung und Oberflächenpräsentation des monoklonalen Antikörpers MA18/7 97

4.2.1 Klonierung des monoklonalen Antikörpers MA18/7 98

4.2.2 Herstellung des Rezeptorimitats 101

4.2.3 Nachweis der Produktion von MA18/7 in COS7-Zellen 104

4.2.4 Nachweis der Oberflächenpräsentation von MA18/7 106

4.2.5 Nachweis der Bindung von HBsAg an MA18/7-transfizierten Zellen 109

4.2.6 Nachweis der Bindung von HBV-Virionen an MA18/7-transfizierten Zellen 111

$\begin{array}{lll}4.2 .7 & \text { Infektionsversuch } & 113\end{array}$ 
5

DISKUSSION

5.1 Kartierung von Aminosäuren, die an der Umhüllung des Nukleokapsids beteiligt sind

5.1.1 Kristallstrukturanalyse des Coreproteins und Auswahl der Kandidaten 116

5.1.2 An der Umhüllung beteiligte Aminosäuren 118

5.1.3 Die Spitze des Spikes ist nicht an der Umhüllung beteiligt 121

5.1.4 An der Partikelbildung beteiligte Aminosäuren 123

5.1.5 Grenzen der Interpretation 126

5.2 Ansatz zur Infektion etablierter Leberzellkulturen mit HBV 128

5.2.1 Klonierung von MA18/7 und Herstellung des Rezeptorimitats 131

5.2.2 Produktion und Oberflächenpräsentation des Rezeptorimitats 133

5.2.3 Bindung und Aufnahme von HBV-Virionen 135

$\begin{array}{lll}\text { 5.2.4 Infektionsversuch } & 136\end{array}$

$\begin{array}{lll}6 & \text { ZUSAMMENFASSUNG } & 137\end{array}$

$7 \quad$ LITERATURVERZEICHNIS $\quad 138$ 


\section{ABKÜRZUNGEN}

Die in dieser Arbeit verwendeten ein- und dreibuchstabigen Abkürzungen sowie alle physikalischen Größen entsprechen der Konvention der „International Union for Biochemistry (LIÉBECQ, 1978). Grundsätzlich werden die international üblichen chemischen Symbole und Abkürzungen der SI-Einheiten (Systeme International d'Unites) benutzt.

\begin{tabular}{|c|c|}
\hline A & Adenosin \\
\hline Abb. & Abbildung \\
\hline $\mathrm{Ag}$ & Antigen \\
\hline Ak & Antikörper \\
\hline Amp & Ampicillin \\
\hline anti- & Antikörper gegen \\
\hline AP & Alkalische Phosphatase \\
\hline APS & Ammoniumpersulfat \\
\hline AS & Aminosäure \\
\hline ATP & Adenosin-5'-triphosphat \\
\hline bidest. & doppelt destilliert \\
\hline bp & Basenpaare (engl.: base pairs) \\
\hline BSA & Rinderserumalbumin (engl.: bovine serum albumin) \\
\hline $\mathrm{C}$ & Cytosin \\
\hline ca. & circa \\
\hline $\operatorname{ccc}$ & $\begin{array}{l}\text { ringförmig, doppelsträngig geschlossen (engl.: covalently closed } \\
\text { circular) }\end{array}$ \\
\hline $\mathrm{Ci}$ & Curie $\left(1 \mathrm{C}=3,7 \times 10^{10}\right.$ Zerfälle pro Sekunde $)$ \\
\hline cpm & Zerfälle pro Minute (engl.: counts per minute) \\
\hline СТP & Cytosin-5'-triphosphat \\
\hline $\mathrm{Da}$ & Dalton \\
\hline dATP & Desoxyadenosin-5' -triphosphat \\
\hline $\mathrm{dCTP}$ & Desoxycytosin-5' -triphosphat \\
\hline ddNTP & Didesoxynukleotid-5'-trihosphat \\
\hline dGTP & Desoxyguanosin-5'-triphosphat \\
\hline DMSO & Dimethylsulfoxid \\
\hline DNase & Desoxyribonuklease \\
\hline DNA & Desoxyribonukleinsäure (engl.: desoxyribonucleic acid) \\
\hline dNTP & Desoxynukleotid-5'-triphosphat \\
\hline DR & Wiederholungssequenz (engl.: direct repeat) \\
\hline dsDNA & doppelsträngige Desoxyribonukleinsäure \\
\hline DTT & Dithiothreitol \\
\hline E. coli & Escherichia coli \\
\hline EDTA & Ethylendiamintetraacetat \\
\hline
\end{tabular}




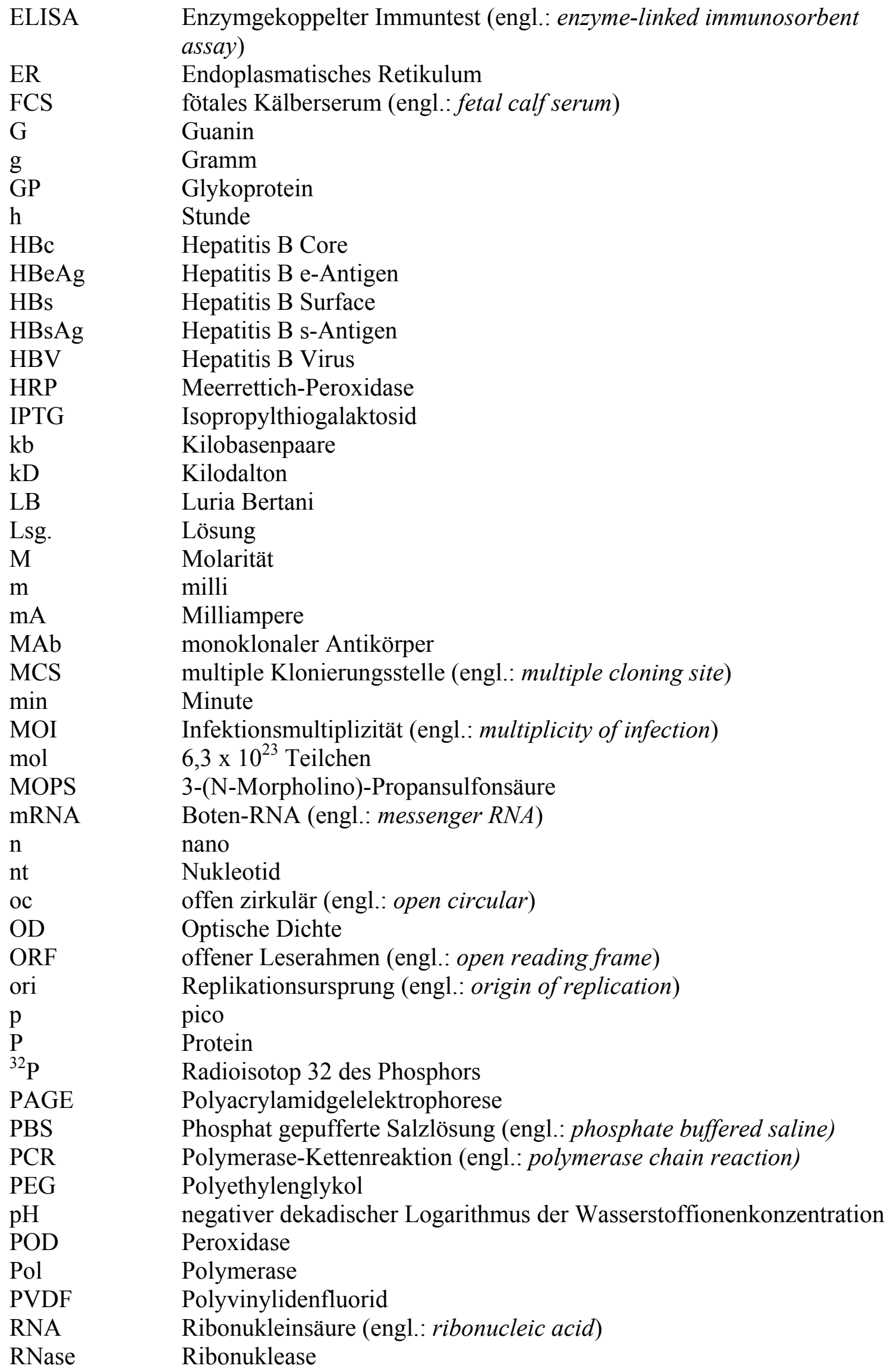




$\begin{array}{ll}\text { rpm } & \text { Umdrehung pro Minute (engl.: rotation per minute) } \\ \text { RT } & \text { Reverse Transkriptase } \\ { }^{35} \text { S } & \text { Radioisotop 35 des Schwefels } \\ \text { SDS } & \text { Natriumdodecylsulfat (engl.: sodiumdodecylsulfat) } \\ \text { sek } & \text { Sekunden } \\ \text { SF } & \text { Spodoptera frugiperda } \\ \text { spez. Akt. } & \text { spezifische Aktivität } \\ \text { ssDNA } & \text { einzelsträngige DNA (engl.: single stranded DNA) } \\ \text { suppl. } & \text { supplementiert } \\ \text { SV40 } & \text { Affenvirus 40 (engl.: simian virus 40) } \\ \text { T } & \text { Thymin } \\ \text { Tab. } & \text { Tabelle } \\ \text { TAE } & \text { Tris-Acetat-EDTA-Puffer } \\ \text { Taq } & \text { Thermus aquaticus } \\ \text { TBE } & \text { Tris-Borat-EDTA-Puffer } \\ \text { TE } & \text { Tris-EDTA-Puffer } \\ \text { TEMED } & \text { N, N, N', N'-Tetraethylendiamin } \\ \text { TP } & \text { Terminales Protein } \\ \text { Tris } & \text { Trishydromethylaminomethan } \\ \text { tRNA } & \text { Transfer-RNA (engl.: transfer RNA) } \\ \text { U } & \text { Einheit (engl.: unit) } \\ \text { UE } & \text { Untereinheiten } \\ \ddot{\text { ü.N. }} & \text { über Nacht } \\ \text { UV } & \text { ultraviolett } \\ \text { V } & \text { Volt } \\ \text { Vol. } & \text { Volumen } \\ \text { v/v } & \text { Volumen pro Volumen } \\ \text { W } & \text { Watt } \\ \text { w/v } & \text { Gewicht (engl.: weight) pro Volumen } \\ \text { X-Gal } & \text { 5-Chlor-4-Brom-3-indolyl-D-Galaktosid } \\ \mu & \text { micro } \\ & \end{array}$

\section{Aminosäuren}

$\begin{array}{llllll}\text { A } & \text { Ala } & \text { Alanin } & \text { M } & \text { Met } & \text { Methionin } \\ \text { C } & \text { Cys } & \text { Cystein } & \text { N } & \text { Asn } & \text { Asparagin } \\ \text { D } & \text { Asp } & \text { Asparaginsäure } & \text { P } & \text { Pro } & \text { Prolin } \\ \text { E } & \text { Glu } & \text { Glutaminsäure } & \text { Q } & \text { Gln } & \text { Glutamin } \\ \text { F } & \text { Phe } & \text { Phenylalanin } & \text { R } & \text { Arg } & \text { Arginin } \\ \text { G } & \text { Gly } & \text { Glycin } & \text { S } & \text { Ser } & \text { Serin } \\ \text { H } & \text { His } & \text { Histidin } & \text { T } & \text { Thr } & \text { Threonin } \\ \text { I } & \text { Ile } & \text { Isoleucin } & \text { V } & \text { Val } & \text { Valin } \\ \text { K } & \text { Lys } & \text { Lysin } & \text { W } & \text { Trp } & \text { Tryptophan } \\ \text { L } & \text { Leu } & \text { Leucin } & \text { Y } & \text { Tyr } & \text { Tyrosin }\end{array}$




\section{Einleitung}

\section{1 Überblick}

Ca. 350 Millionen Menschen weltweit sind mit dem Hepatitis-B-Virus (HBV) chronisch infiziert. Die Infektion kann über kleinste Mengen von Blut oder Blutprodukte, selten durch andere HBV-haltige Körperflüssigkeiten übertragen werden. 80 bis $90 \%$ der Infektionen sind selbstlimitierend mit vollständiger Ausheilung. Das Immunsystem eliminiert das Virus und baut eine Immunität auf. In etwa 0,5 bis $1 \%$ der Fälle kommt es zu einer fulminanten Hepatitis, die meist tödlich verläuft. 5 bis $10 \%$ der Infektionen entwickeln eine persistierende Infektion, die in drei unterschiedliche Formen unterteilt wird: Man unterscheidet zwischen dem gesunden HBV-Träger, der keine klinischen Symptome zeigt, der chronischen Hepatitis mit geringer Leberveränderung und schließlich der chronisch aggressiven Hepatitis, die progredient verläuft. Die als Folge einer HBV-Infektion auftretende Leberzellschädigung ist nicht auf aktive zytopathische Wirkung des Virus zurückzuführen, sondern vielmehr auf die Immunantwort des Wirts. Das Risiko, eine Leberzirrhose oder ein Leberkarzinom $\mathrm{zu}$ entwickeln, ist bei chronischen HBV-Trägern 200 mal höher als bei nicht-infizierten (BEASLEY et al., 1981).

Das HBV wird der Virusfamilie Hepadnaviridae zugeordnet. Der Familienname beinhaltet die Eigenschaften der Hepatozytenspezifität sowie das partiell doppelsträngige DNA-Genom, welches über ein RNA-Intermediat repliziert. Man unterteilt die Familie in zwei Unterfamilien, den Orthohepadnaviridae, zu denen das Hepatitisvirus des Menschen ("human hepatitis B virus", HBV), des Waldmurmeltiers ("woodchuck hepatitis virus", WHV; SUMMERS, et al., 1978), des Erdhörnchens ("ground squirrel hepatitis virus", GSHV; MARION et al., 1980) und des Wollaffens ("wooly monkey hepatitis virus", WMHBV; LANFORD et al., 1998) sowie die Unterfamilie der Avihepadnaviridae, denen das Hepatitis-B-Virus der Pekingente (“duck hepatitis B virus", DHBV; MASON et al., 1980), und des Graureihers ("heron hepatitis B virus" HHBV; SPRENGEL et al., 1988) zugeordnet werden. 
Die Entdeckung des HBV erfolgte in den späten 60er Jahren (BLUMBERG et al., 1965), nachdem schon zuvor beobachtet wurde, dass bestimmte Formen der Hepatitis durch Infektionen verursacht wurden. Inzwischen ist bekannt, dass das in großen Mengen von infizierten Leberzellen produzierte HBsAg Epitope für einen sicheren Impfschutz präsentiert. Das Anfangs aus infizierten Patienten aufgereinigte HBsAg wurde daraufhin erfolgreich als Impfstoff eingesetzt, welches seit 1984 rekombinant durch Hefen hergestellt wird (MC ALEER et al., 1984). Die Standardbehandlung chronisch persistierender HBV-Infektionen basiert auf Kombinationen von Interferon $\alpha$ und Chemotherapeutika, die die virale Polymerase hemmen, wie 3TC oder Adefovir. Eine heilende Therapie ist derzeit noch nicht verfügbar, weshalb Untersuchungen der Morphogenese des Virus zur Entwicklung zusätzlicher antiviraler Strategien führen könnten.

\subsection{Das Hepatitis-B-Virus-Genom}

Mit 3,2 kb besitzt das HBV eines der kleinsten Genome unter den DNA-Viren. Es ist zirkulär, aber nur partiell doppelsträngig und besteht aus einem vollständigen und kodierenden (-)-Strang und einem unvollständigen, nicht kodierenden komplementären $(+)$-Strang. Die Zirkularisierung des Genoms ist nicht kovalent, sondern wird durch Doppelstrangbildung der beiden komplementären 5'-Enden erreicht, die auch als kohäsive Überlappungsregion bezeichnet werden (SATTLER und ROBINSON, 1979). Am 5'-Ende des (-)-Stranges ist kovalent das virale terminale Protein gebunden, während der 5' des (+)-Stranges aus einem kurzen RNA-Stück besteht. Beide 5'-Enden beginnen mit repetitiven Sequenzen von 11 Nukleotiden (DR, engl.: direct repeat). Das 5'-Ende des (-)-Stranges beginnt im Bereich des DR1, während das 5'-Ende des (+)-Stranges mit DR2 beginnt. Beide Sequenzen haben wichtige Rollen bei der Replikation des Genoms.

Das 3'-Ende des (+)-Stranges und somit auch die Länge dieses Stranges ist variabel (HRUSKA et al., 1977) und nicht kovalent mit der viralen Polymerase gebunden. Der 


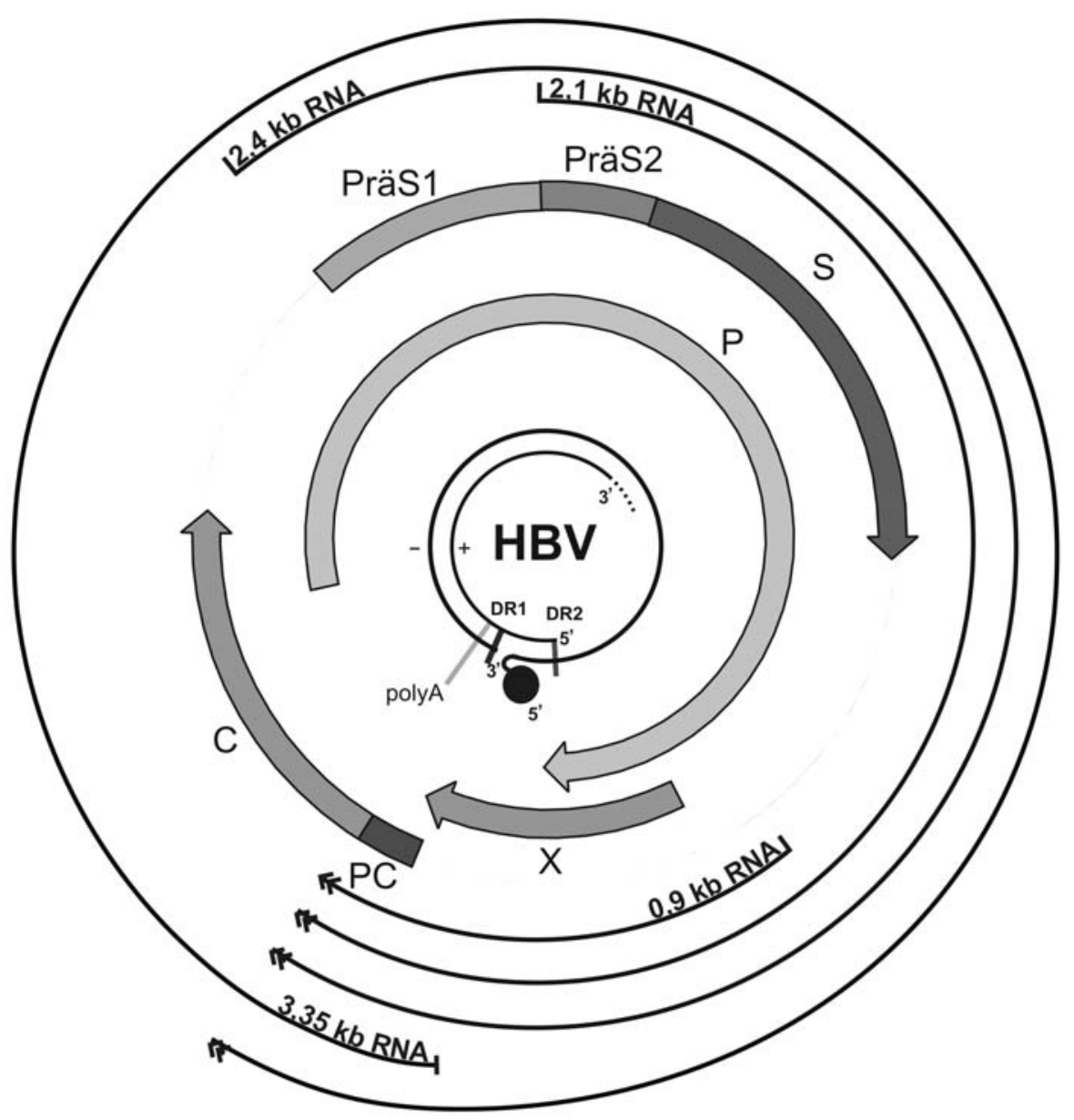

Abb. 1: Darstellung des HBV-Genoms mit offenen Leserahmen und viralen RNAs. S: Leserahmen des kleinen Hüllproteins; PräS2/PräS1: Leserahmen des mittleren und großen Hüllproteins; P: Leserahmen der viralen Polymerase; X: Leserahmen des X-Proteins; C: Leserahmen des Coreproteins; PC: Leserahmen des Präcore-Bereichs; DR1 und DR2: repetitive Sequenzen (direct repeats); polyA: Polyadenylierungssignal

Zustand des (+)-Stranges kann als unterbrochen bezeichnet werden; nach Transport in den Zellkern wird dieser vollständig zur kovalent geschlossenen ringförmigen DNA (ccc-DNA) aufpolymerisiert. Die Organisation des Genoms ist hochkompakt und enthält vier offene Leserahmen (ORF, engl.: open reading frame), die teilweise überlappen (GANEM und VARMUS, 1987). Die ORFs kodieren für die folgenden Virusproteine: Das PräC/C-Gen kodiert für das Coreprotein und das Präcoreprotein. Das PräS/S-Gen kodiert für die drei Formen des Hüllproteins. Hierbei bilden zwei 
alternative Startkodons stromaufwärts die N-terminalen PräS2- und PräS1/2-Domänen des mittleren bzw. großen Hüllproteins. Das P-Gen kodiert für die virale Polymerase und das X-Gen für das X-Protein. Das Genom enthält insgesamt nur ein Polyadenylierungssignal, welches von allen drei viralen RNAs genutzt wird sowie vier Promotoren und zwei Enhancer (SCHALLER und FISCHER, 1991)

\subsection{Genprodukte und Virusstruktur}

Das sphärische Hepatitis-B-Virion besteht aus einem inneren ikosaedrischen Nukleokapsid sowie einer äußeren Virushülle.

Das Nukleokapsid ist ein Homooligomer aus 180 bzw. 240 Coreproteinen mit einem Molekulargewicht von $21 \mathrm{kD}$. Es umschließt das virale partiell doppelsträngige DNAGenom (ROBINSON et al., 1974) sowie die daran gebundene virale Polymerase (KAPLAN et al., 1973) Neben den viralen Komponenten findet man auch eine Proteinkinase zellulären Ursprungs (SCHLICHT und SCHALLER, 1989), die bei der Phosphorylierung des Coreproteins eine Rolle spielt.

Das Nukleokapsid wird von einer äußeren Membran umhüllt, welche transmembran drei Hüllproteine unterschiedlicher Größe und Glykosylierungsform enthält. Das kleine Hüllprotein (SHBs-Protein) ist 226 Aminosäuren groß und besitzt ein Molekulargewicht von $24 \mathrm{kD}$. Es besitzt zwei hydrophobe Signalsequenzen, die eine kotranslationale Translokalisation des Proteins und mehrfache Durchspannung der ER-Membran bewirken. Signalpeptid I befindet sich an Position 4 bis 28 und wird nicht wie üblicherweise posttranslational abgespalten (EBLE et al. 1986). Signalpeptid II befindet sich an Position 80 bis 100, wird von Signalpeptid III durch eine zytoplasmatische Schleife von ca. 50 Aminosäuren getrennt und durchspannt ebenfalls die Membran. Ihr folgen etwa weitere 70 luminal exponierte Aminosäuren des C-Terminus, die die S-spezifischen Epitope sowie eine fakultative N-Glykosylierungsstelle tragen (EBLE et al., 1987). Der C-Terminus besitzt ebenfalls einen hydrophoben Charakter und durchspannt möglicherweise weitere zweimal die ER-Membran (STIRK et al, 1992). Wegen der fakultativen Glykosylierungsstelle liegen ca. 40 \% des kleinen Hüllproteins 
als nichtglykosylierte Form (P24) neben der glykosylierten Form (P27) vor (PETERSON, 1981).

Das mittlere Hüllprotein MHBs ist 281 Aminosäuren lang und entsteht durch Translation von einem alternativen 5'-gelegenen Startkodon aus einer N-terminalen Addition von 55 Aminosäuren der PräS2-Domäne an die C-terminale Sequenz des kleinen Hüllproteins. Es besitzt eine molekulare Masse von $30 \mathrm{kD}$ und kann durch zwei N-Glykosylierungsstellen als Glykoproteine GP33 und GP36 vorliegen (STRIBBE und GERLICH, 1982). Die Membrantopologie des mittleren Hüllproteins ist die gleiche wie die des kleinen. Die N-terminale PräS2-Domäne ist luminal lokalisiert (EBLE et al. 1990)

Das große Hüllprotein (LHBs) besteht aus der PräS1/PräS2-Region und dem S-Protein. Je nach Subtyp variiert die Länge des PräS1/PräS2-Bereichs zwischen 108 und 119 Aminosäuren. Es kann als nicht glykosyliertes Protein mit einem Molekulargewicht von $39 \mathrm{kD}$ oder als glykosylierte Form mit $42 \mathrm{kD}$ vorliegen, wobei lediglich die Glykosylierungsstelle des S-Proteins genutzt wird (HEERMANN et al., 1984). Die Morphologie des großen Hüllproteins unterscheidet sich von den anderen beiden Hüllproteinen. Die N-terminale PräS1-Domäne liegt ursprünglich zytosolisch vor. Diese wird jedoch bei der Hälfte der L-Proteine während der Morphogenese des Virus posttranslational durch die Membran transloziert, so dass die Hälfte der PräS-Domänen des L-Proteins später im Virus nach außen zeigt (BRUSS et al., 1994). Somit werden dem L-Protein zwei Funktionen zugeschrieben: Auf der Innenseite der Membran stellt es während der Umhüllung Kontakt zum Nukleokapsid her und auf der Außenseite etabliert es während der Infektion den Virus-Wirtszellkontakt (BRUSS et al., 1996).

Die virale Polymerase besitzt etwa eine Masse von $90 \mathrm{kD}$ und kann in vier Domänen unterteilt werden. Die N-terminale terminale Proteindomäne (TP), die im Virus kovalent an das 5'-Ende des (-)-Stranges gebunden ist, wird von einer Spacerregion, die ohne bekannte Funktion ist, von der folgenden reversen Transkriptasedomäne (RT) und C-terminaler RNaseH-Domäne separiert. Die TP-Domäne übernimmt später in der Replikation des Genoms Primerfunktion während der (-)-Strangsynthese. Die RT-Domäne hat sowohl reverse Transkriptase als auch DNA-abhängige DNA- 


\section{Das Hepatitis-B-Virion}

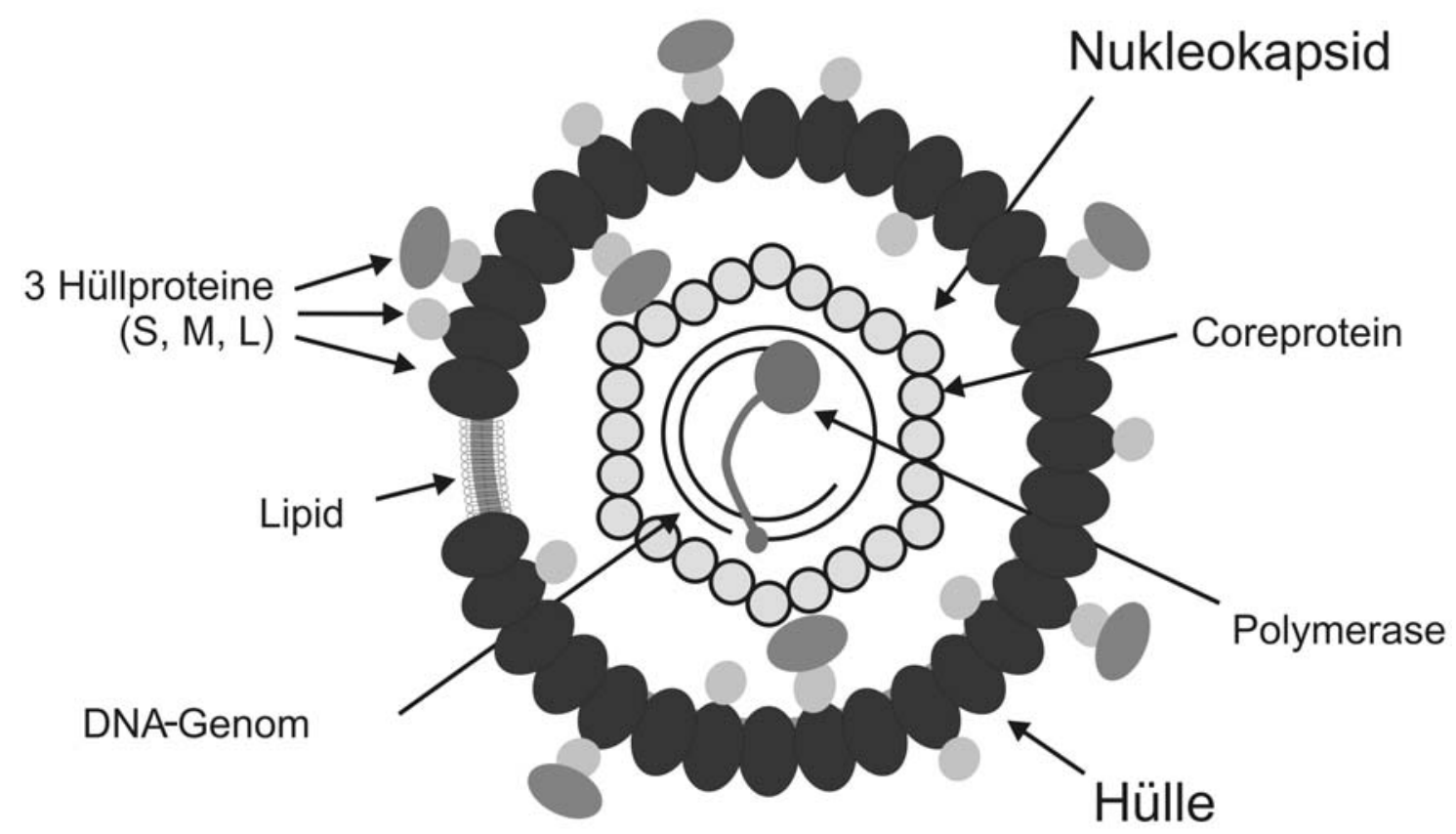

Abb. 2: Aufbau des Hepatitis-B-Virions

Polymeraseaktivität. Die RNaseH-Domäne sorgt für einen gleichzeitigen Abbau der prägenomischen RNA während der Synthese des DNA (-)-Stranges.

Die Funktion des X-Proteins ist derzeit ungeklärt. Es wird die Funktion als Transkriptionsaktivator diskutiert, was durch in vitro Versuche gezeigt werden konnte (Rossner, 1992; KeKUle et al., 1993). Jedoch ist eine Expression des X-Proteins in Zellkultur für eine Virusproduktion nicht essentiell (BLUM et al., 1992) 


\subsection{Virusreplikation}

Die Replikationsstrategie der Hepadnaviren ist unterschiedlich $\mathrm{zu}$ denen anderer Virusfamilien (SUMMERS und MASON, 1982; GANEM und VARMUS, 1987; TIOLLAIS et al., 1981 und 1985). Nach Transport des viralen Genoms in den Zellkern durch das Nukleokapsid wird durch Wirtszellfaktoren das partiell doppelsträngige DNA-Genom aufgefüllt und kovalent geschlossen (KöCK und SCHLicht, 1993). Diese ccc-DNAForm dient dann als Matrize zur Transkription der vier viralen RNAs. Neben zwei kleineren viralen RNAs transkribiert die DNA-Polymerase II der Wirtszelle eine 3,35 $\mathrm{kb}$ große RNA, die auch als prägenomische RNA bezeichnet wird (HUANG und SuMMERS, 1991). Sie unterscheidet sich von einer weiteren 3,35 kb großen RNA, die jedoch am 5'-Ende etwas länger ist und das Startkodon für die Synthese des PräcoreProteins enthält. Nur die kürzere Variante dient als Prägenom, da die Translation des Präcore-Proteins als Konkurrenzreaktion zur Bindung der viralen Polymerase stattfindet (NAssal et al., 1990). Die virale Polymerase bindet an die $\varepsilon$-Sequenz des 5'-Endes der prägenomischen RNA innerhalb der DR1-Region vor dem Startkodon des Coreproteins, die hier eine "stem-loop" Struktur ausbildet. Hierdurch wird die Synthese des Coreproteins verhindert und die Verpackung des prägenomischen RNA-Pol-Komplexes durch Assemblierung des Kapsids initiiert. Erst nach Kapsidassemblierung kommt es zur Generierung des viralen Genoms (BARTENSCHLAGER et al., 1990), wobei die prägenomische RNA als Vorlage für die DNA-Synthese dient (HowE und TYRELL, 1996).

Die reverse Transkription im Inneren des Nukleokapsids beginnt mit der (-)-StrangSynthese (BLuM et al., 1984) durch Synthese eines Tetranukleotids, wobei die TP-Domäne als Primer fungiert (GERLICH und RoBINSON, 1980). Hier findet eine kovalente Verknüpfung der Aminosäure Y96 der TP-Domäne mit dem ersten Nukleotid statt. Nach diesem “(-)-Strang-priming” wird der Pol-Primerkomplex zu der terminalen redundanten Sequenz am 3'-Ende der prägenomischen RNA transloziert. Vom 3'-Ende aus startet daraufhin die (-)-Strang-Synthese bei gleichzeitigem Abbau der prägenomischen RNA durch die RNaseH-Domäne mit Ausnahme eines kurzen Fragments von 15 bis 18 Nukleotiden (LOEB et al., 1991) in der DR1-Region am 5'-Ende der RNA (CHANG et al., 1990; RADZIWILl et al., 1990). Dieses Fragment wird daraufhin ans 5'-Ende des entstandenen DNA-Stranges transloziert, wo es in der DR1- 
Region hybridisiert und als Primer für die (+)-Strang-Synthese fungiert (LIEN et al., 1986 u. 1987). Die (+)-Strang-Synthese findet nach Zirkularisierung des Minusstranges durch die terminalen redundanten Enden statt und bricht nach der Synthese von 1000 - 2000 Basen ab.

\subsection{Infektionszyklus des Hepatitis-B-Virus}

Die Aufnahme des HBV in die Leberzelle ist bislang noch ungeklärt. Diskutiert wird in diesem Zusammenhang eine rezeptorvermittelte Aufnahme, bei der das Virus die Hülle verliert und als Nukleokapsid ins Zytosol gelangt. Studien an primären Entenhepatozyten zeigten, dass das Zelloberflächenprotein Carboxypeptidase D (gp180) zumindest eine Rezeptorkomponente darstellt (BREINER et al., 1998; ENG et al., 1998; IsHIKAWA et al., 1998). Expression dieses Proteins in menschlichen Hepatozyten vermittelt jedoch noch keine Infektion (BREINER et al., 1998).

Das virale Genom wird nach Eintritt des Nukleokapsids in den Zellkern rekrutiert. Das Nukleokapsid versteht sich hierbei mit seinen Kernlokalisationssignalen (NLS) als Transporter. Im Kern wird das partiell doppelsträngige DNA-Genom durch Wirtsfaktoren vollständig aufpolymerisiert und kovalent verschlossen (KÖCK und SCHLICHT, 1993). Diese ccc-DNA-Form dient dann als Matrize zur Transkription der vier viralen RNAs. Es werden insgesamt vier verschiedene virale RNAs über vier Promotoren von der wirtseigenen RNA-Polymerase II synthetisiert, die alle an einem Polyadenylierungssignal enden. Die beiden 3,35 kb großen RNAs unterscheiden sich um ca. 30 Nukleotide am 5'-Ende. Die größere der beiden dient als prägenomische RNA. An ihr bindet die virale Polymerase und initiiert als Komplex die Kapsidassemblierung. Die kleinere der 3,35 kb RNAs dient zur Translation der viralen Polymerase und des Coreproteins, die beide im Zytosol der Zelle synthetisiert werden. Von der 2,4 kb großen RNA wird das große Hüllprotein (L) als transmembranes Protein in die ER-Membran translatiert. Die 2,1 kb große RNA dient zur Synthese des mittleren (M) und kleinen (S) Hüllproteins, die ebenfalls in die ER-Membran inseriert werden. Eine 0,9 kb große mRNA dient zur Synthese des X-Proteins. 
In der frühen Phase der Infektion wird das reife Nukleokapsid zum Zellkern zurücktransportiert, disassembliert und entlässt das Genom in den Zellkern. Nach Überführung in die ccc-Form dient es dort als weitere Matrize für die Synthese viraler RNAs. In der Ente läuft dieser Prozess so lange $a b$, bis etwa 20 bis 50 Moleküle ccc-DNA im Zellkern akkumulieren (TUTTLEMAN et al., 1986) Diese Prozesse der frühen Infektionsphase scheinen in Abhängigkeit mit der L-Proteinkonzentration zu stehen. Im DHBV-Modell wurde ein deutlicher Anstieg nukleärer ccc-DNA nach Ausschalten der L-Proteinsynthese beobachtet (LENHOFF et al., 1994)

In der späten Phase der Infektion kommt es zur Umhüllung des reifen Nukleokapsids an der Membran des ER. Hierbei wird ein direkter Kontakt der transmembranen Hüllproteine mit dem Nukleokapsid vorausgesetzt. Neben dem Phänomen der unabhängigen Bildung subviraler Partikel ist für die Bildung von Virionen lediglich das große (L) und das kleine (S) Hüllprotein notwendig (BRUSS und GANEM, 1991). Der N-terminale Bereich des L-Proteins befindet sich auf der cytosolischen Seite der ER-Membran. Zwei Regionen in Endodomänen der Hüllproteine wurden mittels Mutationsanalysen als Interaktionskandidaten des Umhüllungsprozesses identifiziert: Mutationen eines linearen Bereichs von 22 Aminosäuren zwischen Position 103 und 124 mit alleiniger Präsenz im L-Protein (BRUSS, 1997; LE SEYEC et al., 1999) sowie einer zweiten Region zwischen Position 35 und 46 im Bereich des S-Proteins (LÖFFLERMARY et al., 2000) führten zum spezifischen Block der Umhüllung reifer Nukleokapside, jedoch weiterhin zur Sekretion subviraler Partikel. Es besteht die Vorstellung, dass die N-terminale Schleife des großen Hüllproteins als Kontaktpartner einer ProteinProteininteraktion mit dem Nukleokapsid in Verbindung tritt, um dieses zum Zweck der Umhüllungsreaktion näher an die Membran des ER zu rekrutieren.

Die Knospung des Nukleokapsids findet letztendlich in das Lumen des ER statt. Von dort wird es durch den Exportweg aus der Zelle transportiert. 


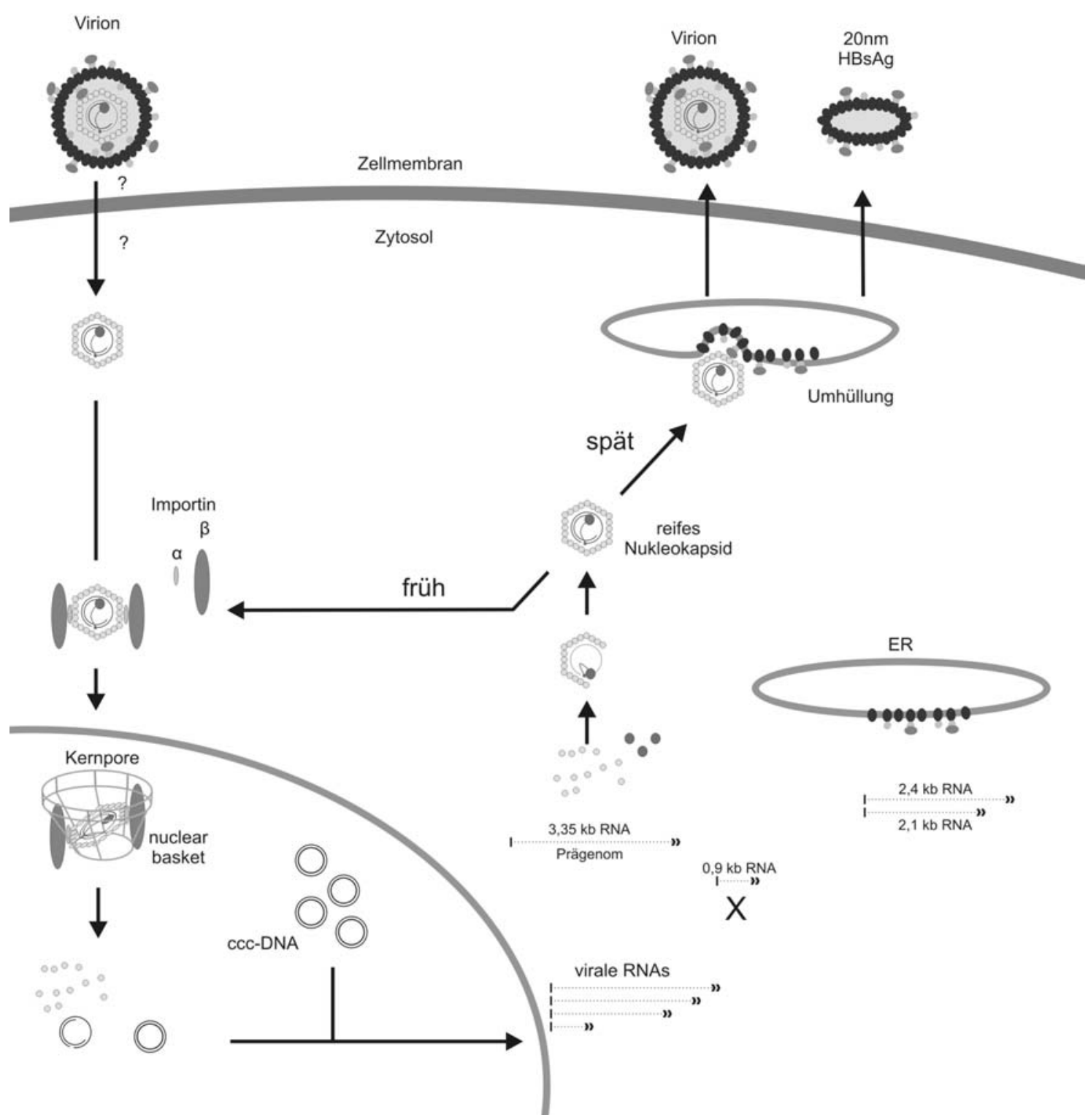

Abb. 3: Graphische Darstellung des Infektionszyklus des Hepatitis-B-Virus

\subsection{Das HBV-Kapsid}

Das HBV-Kapsid besteht je nach Symmetrie aus $180(\mathrm{~T}=3)$ oder $240 \quad(\mathrm{~T}=4)$ Coreproteinen, welche vom Coregen codiert werden. Je nach Subtyp hat das Coreprotein eine Größe von 185 Aminosäuren (Subtyp $a d w$ ) oder 183 Aminosäuren 
(Subtyp ayw) und eine molekulare Masse von $21 \mathrm{kD}$. Die in dieser Arbeit zugrunde gelegten Daten beziehen sich auf den Subtyp adw2.

Das Coreprotein kann in zwei verschiedene Domänen unterteilt werden. Die N-terminale Domäne umfasst die ersten überwiegend hydrophoben 144 Aminosäuren und wird Assemblierungsdomäne genannt (GALlinA et al., 1989; BIRNBAUM und NASSAL, 1990). Die rekombinante Expression einer C-terminal verkürzten Variante 1-149 zeigt morphologisch keine Beeinträchtigung bezüglich der Partikelbildung (ZlotNIK et al., 1997). Der C-terminale Bereich des Proteins umfasst 36 Aminosäuren und ähnelt der Sequenz des Protamin. Er ist basisch, positiv geladen und stark hydrophil. Die überaus argininreiche Region enthält drei SPRRR(R)-Motive, die die Fähigkeit besitzen, DNA zu binden (PETIT und PILOT, 1985). Der C-terminale Bereich des Coreproteins kann an verschiedenen Serinresten phosphoryliert werden, was eventuell in der Regulation der Virusmorphogenese eine Rolle einnimmt. Phosphorylierung des C-Terminus durch eine kapsidassoziierte Proteinkinase $\mathrm{C}$ aus der Wirtszelle (KANN und GERLICH, 1994) unterbindet die DNA-Bindefähigkeit. Während intrazelluläre Kapside am C-Terminus heterogen phosphoryliert sind, findet man bei extrazellulär aus Virionen isolierten Kapsiden überwiegend unphosphoryliertes Coreprotein (YU und SuMMERS, 1994). Des weiteren enthält der C-Terminus ein Kernlokalisationssignal (NLS) (YEH et al., 1990), welches im phosphorylierten Zustand im Kapsid nach außen gerichtet eine Rekrutierung des Proteins in den Zellkern vermittelt (KANN et al., 1999).

Kryoelektronenmikroskopie (BÖTTCHER et al., 1997) und Kristallstrukturdaten (WYNNE et al., 1999) trugen erheblich zur Aufklärung der Faltung des Coreproteins und der Struktur des Kapsids bei.

Das Coreproteinmonomer ist dominiert durch eine lange $\alpha$-helikale Haarnadelstruktur der Helix $\alpha 3$ (As 50 - As 73) und Helix $\alpha 4$ (As 79 - As 110), wobei die Helix $\alpha 4$ an Position 90-92 abgeknickt wird und in den oberen Bereich a4a und den unteren Bereich $\alpha 4 b$ eingeteilt wird. Die N-terminale Region des Coreproteins umschließt diese Haarnadelstruktur, die im Multimer die Hälfte eines Spikes bildet, mit einer Schleife. Auch sie enthält zwei helikale Bereiche $\alpha 1$ (As 13 - As 27) sowie $\alpha 2$ (As 27 - As 43), die an Position 37 geknickt in $\alpha 2 \mathrm{a}$ und $\alpha 2 \mathrm{~b}$ unterteilt wird. Die C-terminale Region 
besteht aus einer weiteren Helix $\alpha 5$ (As 112 - As 127), gefolgt von einer prolinreichen Schleife (As 128 - As 136) und einen erweiterten Strang (ab As 137) (WYNNE et al., 1999).

Zwei Monomere bilden ein kompaktes Dimer, wobei die beiden helikalen Haarnadelschleifen ein kompaktes 4-Helixbündel bilden (CONWAY et al., 1997), die den charakteristischen Spike auf der Oberfläche des Kapsids formt. Beide Monomere liegen sich antiparallel gegenüber und bilden eine fast exakte 2-fach-Symmetrie. Das Coreproteindimer ähnelt der Form einer Spitzhacke, mit dem Spike als Griff und der basalen Region als Kopf. Die Oberfläche der Haarnadelstruktur $\alpha 3-\alpha 4$ Spikes besteht aus einem Großteil amphipatischen hydrophoben Aminosäuren, die zur Dimerstabilisierung beitragen. Eine Disulfidbrücke fixiert beide Haarnadelstrukturen innerhalb des Spikes an Position C61, die allerdings nicht essentiell für Dimer- und Kapsidbildung ist (NASSAL et al., 1992b; ZHENG et al., 1992; ZLOTNICK et al., 1997) sowie zwei Wasserstoffbrückenbindungen zwischen den Aminosäuren E64 1 und K962 und $\mathrm{D} 78_{1}$ und $\mathrm{E} 77_{2}$.

Die Kapsidassemblierung in infizierten Leberzellen wird durch Bildung eines Polymerase-Prägenomkomplexes initiiert. Die virale Polymerase bindet an der $\varepsilon$-Sequenz des Prägenoms und initiiert hierdurch die Assemblierung der Coreproteine unter gleichzeitigem Einschluss des Komplexes (JUNKER-NIEPMANN et al., 1990). Die Assemblierung zum Kapsid ist abhängig von der Konzentration an Coreproteinen (SEIFER et al., 1993). Eine autarke Kapsidassemblierung ohne weitere Viruskomponenten kann jedoch in rekombinaten Expressionssystemen wie in Bakterien (COHEN und Richmond, 1982), Xenopus-Oozyten (ZHOU und StANDERING, 1991) oder Insektenzellen (LANFORD und NOTVALL, 1990) beobachtet werden. Die Kapsidassemblierung findet durch Interdimerkontakte der C-terminalen Domänen statt. Primär sind Seitenketten der Helix $\alpha 5$, der prolinreichen Schleife und des erweiterten Stranges beteiligt. Durch Anlagerungen der C-Termini bilden sich 5-fache und 6-fache Symmetrien, die vor allem in der Mitte von 6-fachen Symmetrien Poren im Durchmesser von etwa $14 \AA ̊$ bilden (WYNNE et al., 1999). Diese Poren sind groß genug, um das Kapsidlumen mit kleinen Molekülen, wie Desoxyribonukleotiden zu versorgen. 
HBV-Kapside besitzen eine hohe Immunogenität und verursachen eine starke B-Zell-, T-Helfer- und zytotoxische T-Zell-Antwort. Das konformationelle Hauptepitop HBc befindet sich im Bereich um Aminosäure 80, auf der Spitze des Spikes. Zwei weitere Epitope $\mathrm{HBe} 1$ und $\mathrm{HBe} 2$ sind durch die Kapsidstruktur maskiert und können nur in Coreproteindimeren oder denaturierten Kapsiden nachgewiesen werden (SALFELD et al., 1989). HBel ist ein sequentielles Epitop und befindet sich ebenfalls um Position 80 im Coreprotein. $\mathrm{HBe} 2$ ist ein weiteres konformationelles Epitop und befindet sich um Position As 130.

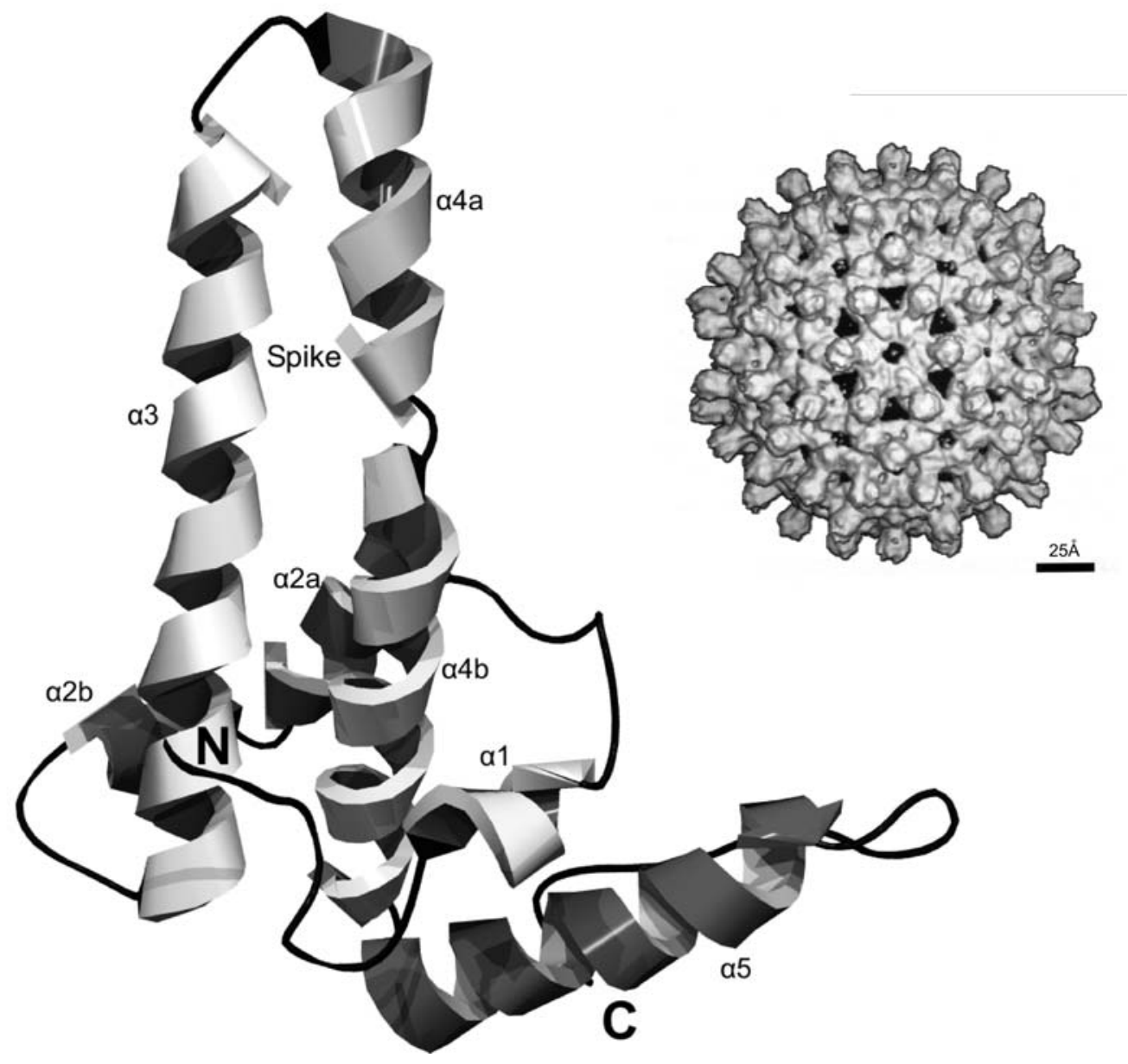

Abb. 4.: Links: Darstellung der Coreproteinfaltung als Monomer (Daten aus der Kristallstrukturanalyse WyNNE et al., 1999). Rechts: Cryo-EM-Bild eines Kapsids mit T=4 Symmetrie, $9 \AA ̊$ Auflösung (CONWAY et al., 1997, modifiziert) 


\subsection{Ziel der Arbeit}

Dem Nukleokapsid stehen nach der Reifung im Zytosol zwei verschiedene Wege zur Verfügung: Vor allem in der frühen Phase der Infektion findet eine Amplifikation nukleärer Genomkopien statt. Das Nukleokapsid wird daher zum Zellkern rekrutiert, das Genom importiert und in die ccc-DNA überführt. In der späten Phase der Infektion kommt es zur Sekretion von Virionen. Hierfür wird das reife Nukleokapsid an der ERMembran umhüllt, erscheint im ER-Lumen und wird durch zelluläre Exportmechanismen aus der Zelle geschleust.

Bei beiden Prozessen werden Kontaktaufnahmen viraler und zellulärer Komponenten mit der Oberfläche des Nukleokapsids postuliert. Der Import des Nukleokapsids in den Zellkern findet über den Importin $\alpha /$ Importin $\beta$ vermittelten zellulären Kerntransport statt, der an Kernlokalisationssignalen (NLS) nach außen exponierter CoreproteinC-Termini bindet (PANTÉ und KANN, 2002). Die nachfolgende Kapsiddisassemblierung ist allerdings vom Reifegrad des Nukleokapsids abhängig (PANTÉ und KANN, 2002) und setzt sicherlich auch Kontaktpunkte mit dem Nukleokapsid voraus.

Für die Umhüllung des reifen Nukleokapsids sind das große (L) und das kleine (S) Hüllprotein notwendig (BRUSS und GANEM, 1991). Zwei Regionen in Endodomänen der Hüllproteine, ein linearer Bereich von 22 Aminosäuren zwischen Position 103 und 124 mit alleiniger Präsenz im L-Protein (BRUSS, 1997; LE SEYEC et al., 1999) sowie eine zweite Region zwischen Position 35 und 46 im Bereich des S-Proteins (LÖFFLER-MARY et al., 2000), führten zum spezifischen Block der Umhüllung reifer Nukleokapside, jedoch weiterhin zur Sekretion subviraler Partikel. Es existiert die Vorstellung, dass die Hüllproteine als Kontaktpartner einer Protein-Proteininteraktion mit dem Nukleokapsid in Verbindung treten, um dieses zum Zweck der Umhüllungsreaktion näher an die Membran des ER zu rekrutieren.

Primäres Ziel dieser Arbeit war die Kartierung von Aminosäureseitenketten auf der Oberfläche des Kapsids, die während der Umhüllung an einer Protein-Proteininteraktion mit den Hüllproteinen teilnehmen. Hierfür sollten Coremutanten hergestellt werden, bei denen oberflächenexponierte Aminosäurereste ausgetauscht und auf ihre Umhüllungskompetenz hin getestet werden sollten. 
Um die gleichen Mutanten bezüglich ihrer Kernimportfähigkeit testen zu können, wurde versucht, ein Modell zum Studium der frühen Phase der Infektion zu entwickeln. Durch Zelloberflächenpräsentation des monoklonalen anti-PräS1-Antikörpers MA18/7 sollte versucht werden, etablierte Zellkulturen wie HuH7 oder HepG2 mit HBV zu infizieren. 


\section{MATerial}

\subsection{Bakterienstamm}

DH5a

(HANAHAN et al., 1983)

\subsection{Zelllinien}

\section{$\operatorname{Cos} 7$}

(GLUZMANN, 1981)

\section{HuH7}

(NAKABAYASHI et al., 1982)

\section{HepG2}

(ADEN et al., 1979)
supE44D, lacU169 (Ф80lacZLM15), hscR17, recA, endA1, gyrA96, thi-1, relA1
Durch Transformation mit Deletionsmutanten des Simian-Virus 40 (SV40) immortalisierten Affennierenzellen. Sie bilden konstitutiv das große TAntigen des Virus und replizieren deshalb mit hoher Effizienz transfizierte Plasmide, die den SV40-origin of replication enthalten.

Humane Hepatomzelllinie, die stabil oder transient mit der Kalziumphosphat-Methode transfizierbar ist.

Zelllinie, die aus Biopsiegewebe eines primären, humanen Leberkarzinoms stammt. Morphologisch handelt es sich um Parenchymzellen, die sich durch adhärentes Wachstum auszeichnen. 


\subsection{Nährmedien}

\subsubsection{Nährmedien zur Anzucht von $E$. coli}

\section{LB-Medium}

5 g Hefeextrakt, 10 g Trypton, $10 \mathrm{~g} \mathrm{NaCl}, \mathrm{H}_{2} \mathrm{O}_{\text {bidest. }}$ ad $1000 \mathrm{ml}$

\section{TB-Medium}

Lösung A: 24 g Hefeextrakt, 12 g Trypton, 6 g NaCl, $\mathrm{H}_{2} \mathrm{O}$ bidest. ad $900 \mathrm{ml}$

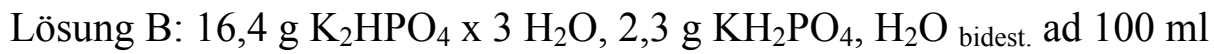

Beide Lösungen werden getrennt hergestellt und autoklaviert. Vor Verwendung wird Lösung A mit Lösung B im Verhältnis $9+1$ supplimiert.

\section{dYT-Medium}

$10 \mathrm{~g}$ Hefeextrakt, $16 \mathrm{~g}$ Trypton, $5 \mathrm{~g} \mathrm{NaCl}, \mathrm{H}_{2} \mathrm{O}_{\text {bidest. }}$ ad $1000 \mathrm{ml}$

Zur Sterilisation wurden die Nährmedien für $20 \mathrm{~min}$. bei $180{ }^{\circ} \mathrm{C}$ autoklaviert. Für feste Nährböden wurden vor dem Autoklavieren 1,5 \% (w/v) Bacto-Agar zugegeben. Zur Herstellung von Selektivnährmedium (-boden) wurde Ampicillin aus einer Stocklösung bis zu einer Endkonzentration von 100 mg/l hinzugegeben.

\subsubsection{Nährmedien zur Kultivierung von Zellkulturen}

DMEM suppl. (COS7, $\mathrm{HuH} 7)$

DMEM, 10 \% fötales Kälberserum (FCS), 1 \% Antibiotikum-Antimykotikum 


\section{DMEM/Met ${ }^{-} / \mathrm{Cys}^{-}$suppl. (COS7)}

DMEM, ohne Methionin, ohne Cystein, 4 mM Glutamin

\section{HepG2 Medium suppl. (HepG2)}

67 \% (v/v) MEM, 22 \% (v/v) Medium 199, 5 mg/1 Insulin, 0,175 mg/l Hydrocortison, $10 \%$ fötales Kälberserum (FCS), $1 \%$ Antibiotikum-Antimykotikum

\subsection{Enzyme}

DNase I

Proteinase-K

Restriktionsendonukleasen

RNase A

T4 DNA-Ligase

Taq DNA-Polymerase

Pfu DNA-Polymerase

Trypsin
Roche, Mannheim

Amrexco, Ohio, USA

New England Biolabs, Schwalbach

Roche, Mannheim

Invitrogen, Groningen, Niederlande

Roche, Mannheim

Stratagene, Heidelberg

Sigma, Steinheim 


\subsection{Plasmide}

pCR2.1 (Invitrogen)

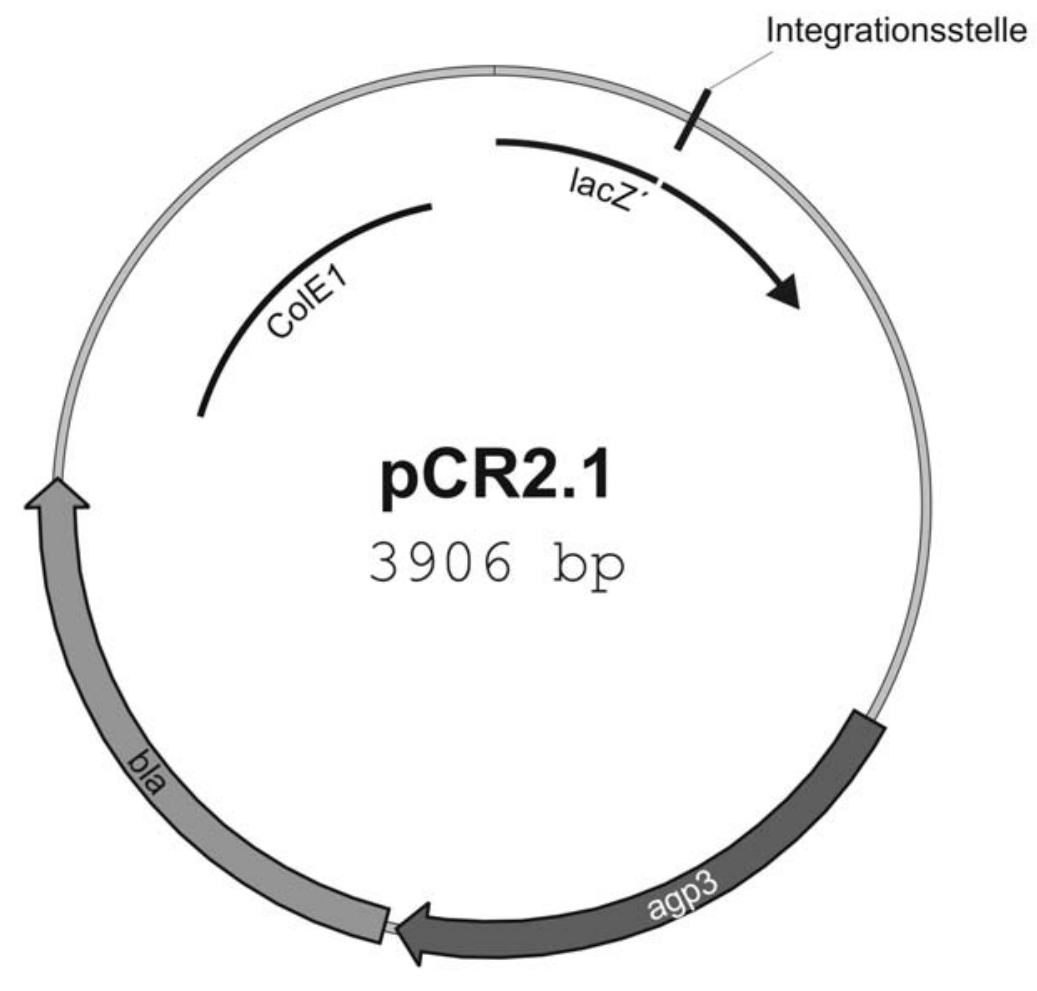

Abb. 5: Graphische Darstellung des Plasmids pCR2.1 (Invitrogen).

bla: Gen für die $\beta$-Lactamase (vermittelt Ampicillinresistenz), agp3: Kanamycinresistenzmarker, ColE1: prokaryotischer Replikationsursprung, lacZ: $\beta$-Galaktosidase

Das Plasmid pCR2.1 entstammte dem Klonierungs-Kit der Fa. Invitrogen und wurde zur direkten Klonierung von PCR-Produkten eingesetzt. Das Plasmid liegt in linearer Form vor. Beide Enden des linearen Plasmids tragen 3'-T-Überhänge, so dass durch TAQ-Polymerase amplifizierte DNA entweder direkt durch Ligation (3.1.2.3) (TACloning Kit) oder durch kovalent an diese Enden gebundene Topoisomerase (Topo-TACloning Kit) in das Plasmid integriert wird. 
pSVcore (KoscheL et al., 2000)

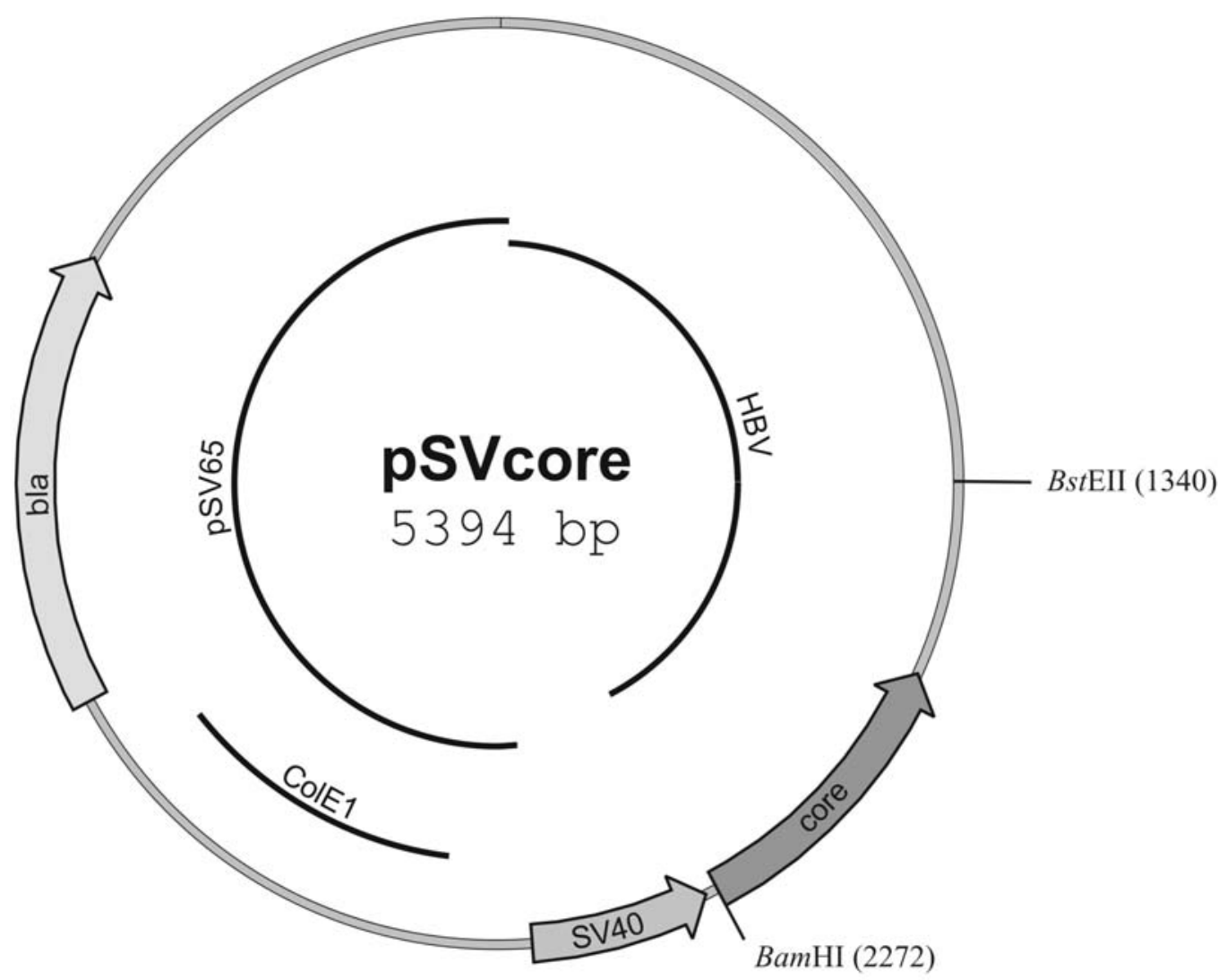

Abb. 6: Graphische Darstellung des Plasmids pSVcore.

SV40: SV40-early-Promotor, core: Leserahmen des Coreproteins, bla: Gen für die $\beta$-Lactamase (vermittelt Ampicillinresistenz), ColE1: prokaryotischer Replikationsursprung, lacZ: $\beta$-Galaktosidase

Dieses eukaryotische Expressionsplasmid diente zur transienten Expression des Coreproteins sowie aller in dieser Arbeit hergestellten Coremutanten. $\mathrm{Zu}$ seiner Herstellung wurde ein 930 bp großes HBV-Fragment, welches das Coreprotein trägt, aus dem Plasmid pMKVIII (Koschel et al., 2000) über die Restriktionsschnittstellen BamHI und BstEII in das Plasmid pSVBX24H (BRUSS und GANEM, 1991) eingesetzt. 
pSVHBV1.5core ${ }^{-}$(KOSCHEL et al., 2000)

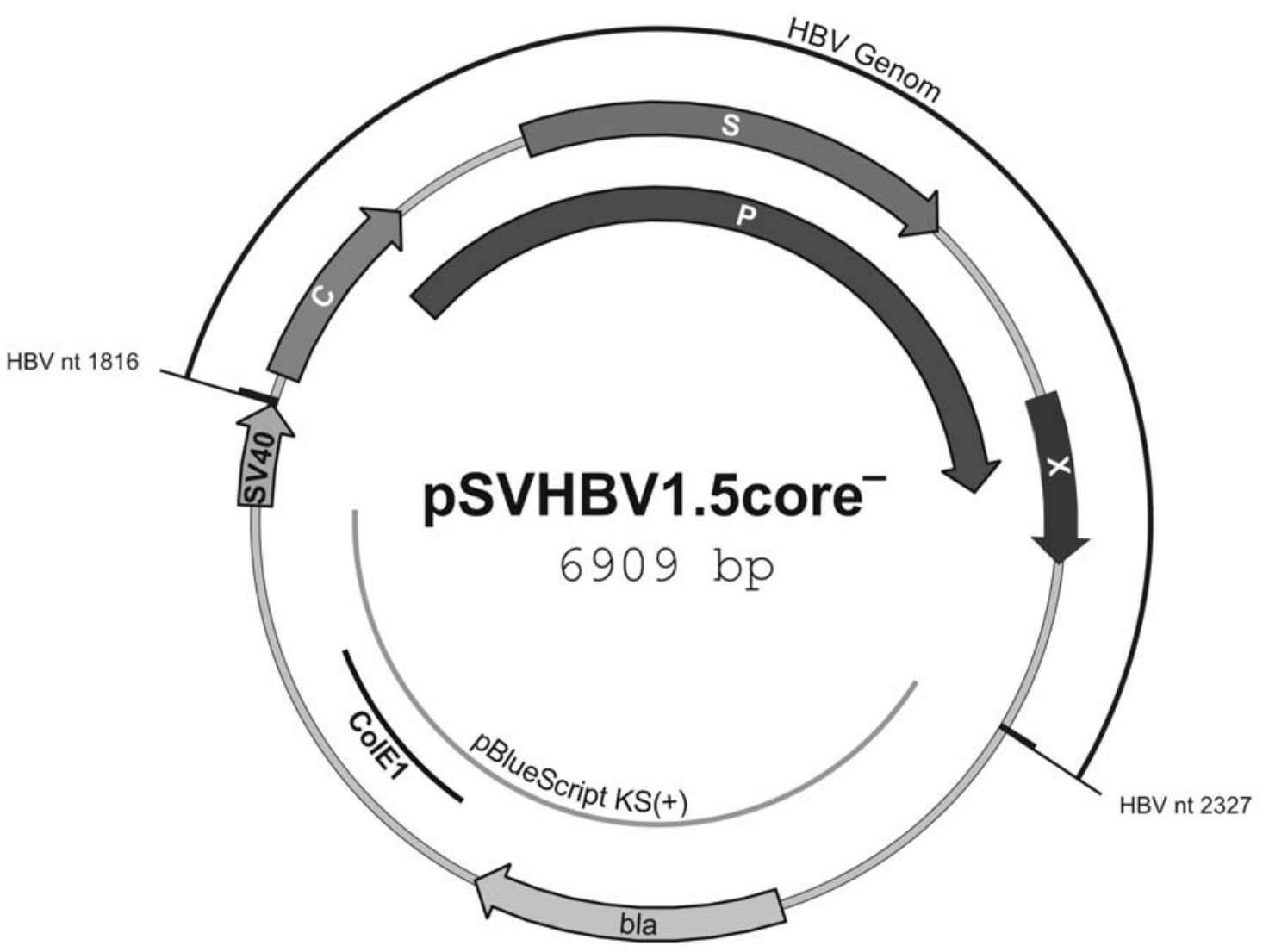

Abb. 7: Graphische Darstellung des Plasmids pSVHBV1.5core-

SV40: SV40-early-Promotor, C: Leserahmen des Coreproteins, S: Leserahmen der Hüllproteine, P: Leserahmen des P-Proteins, X: Leserahmen des X-Proteins, bla: Gen für die $\beta$-Lactamase (vermittelt Ampicillinresistenz), ColE1: prokaryotischer Replikationsursprung

Die 1,5-fache Kopie des HBV-Genoms (Subtyp adw2, VALENZUELA et al., 1980) mit einer Länge von 4,5 kb wurde über die Restriktionsschnittstellen EcoRV und BspEI in den Vektor pBluescript KS(+) (Stratagene, Heidelberg) inseriert. Der Core-Promotor der HBV-DNA wurde durch einen SV40-early-Promotor ersetzt. Das Kodon der Aminosäure Tyr38 wurde von TAT zu einem TAG Stop-Kodon mutiert, so dass von diesem Plasmid alle Virusproteine mit Ausnahme des Coreproteins exprimiert werden. 
pSVBX24H (BRUSS et al., 1991)

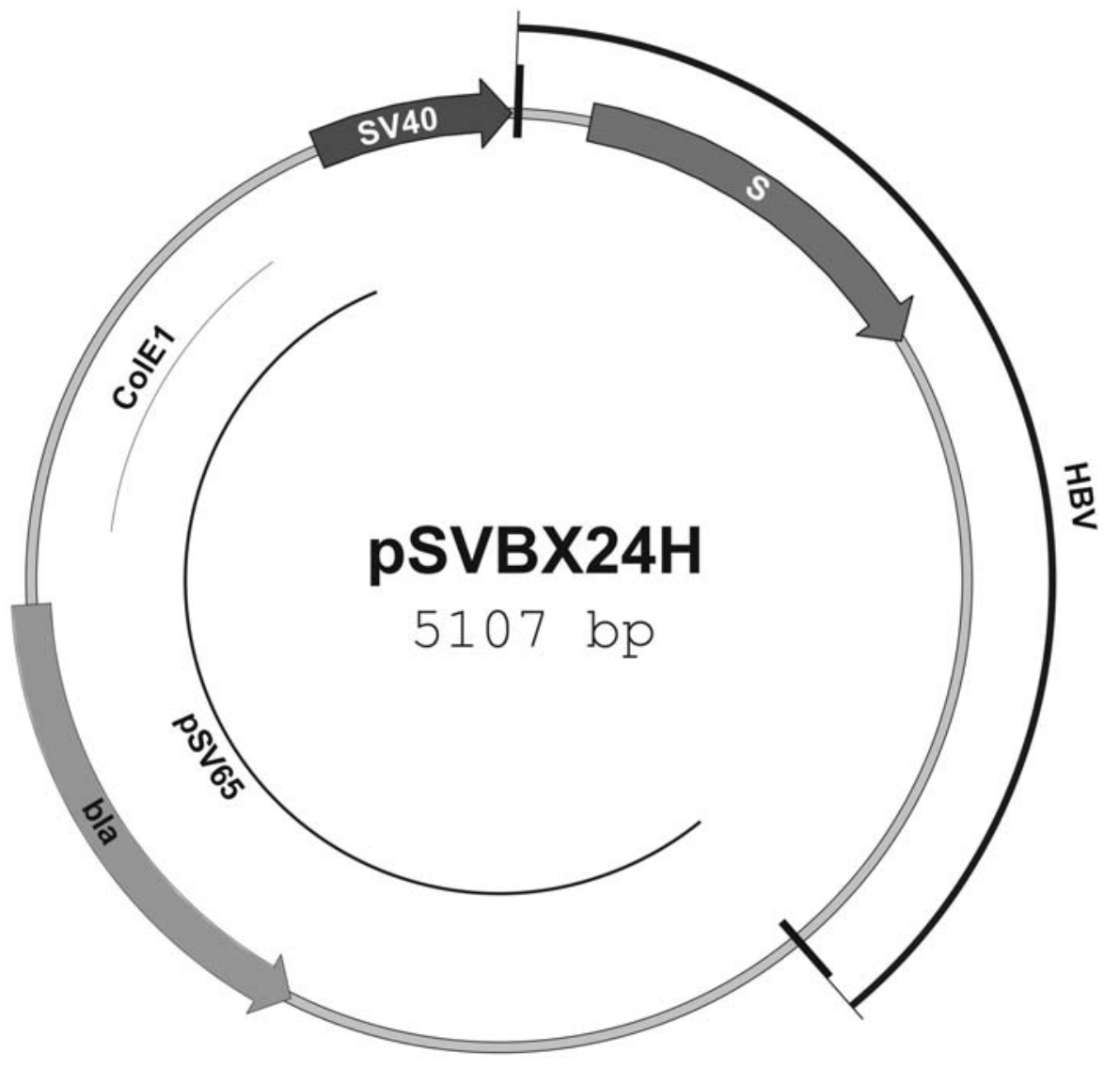

Abb. 8: Graphische Darstellung des Plasmids pSVBX24H.

SV40: SV40-early-Promotor, S: Leserahmen der Hüllproteine, bla: Gen für die $\beta$-Lactamase (vermittelt Ampicillinresistenz), ColE1: prokaryotischer Replikationsursprung

Das Plasmid pSVBX24H wurde durch Insertion eines 1,9 kb großen HBV-Fragments in den Expressionsvektor pSV65 hergestellt. Das HBV-Fragment trägt die Information des kleinen Hüllproteins (S) sowie das Polyadenylierungssignal. Als Promotor dient der SV40-early-Promotor. pSVBX24H fungierte als Kontrollplasmid zur Expression des kleinen Hüllproteins. 
pSV-LIgGHC9IgDTM (diese Arbeit)

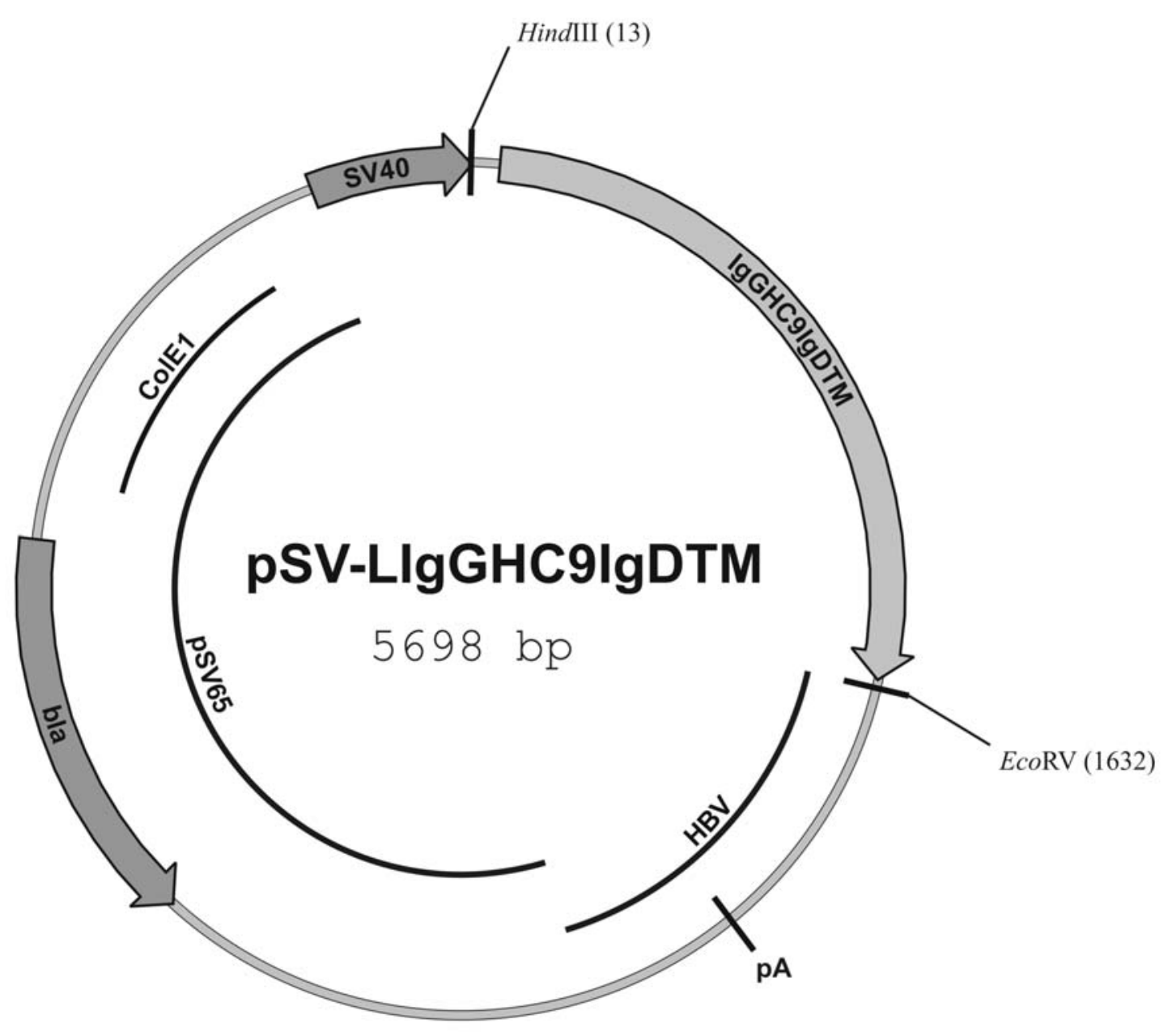

Abb. 9: Graphische Darstellung des Plasmids pSV-LIgGHC9IgDTM.

SV40: SV40-early-Promotor, IgGHC9IgDTM: Leserahmen des Fusionsproteins der schweren Kette des MA18/7-Antikörpers mit der IgD-Transmembrandomäne, pA: HBVPolyadenylierungssignal, bla: Gen für die $\beta$-Lactamase (vermittelt Ampicillinresistenz), ColE1: prokaryotischer Replikationsursprung.

Das Plasmid pSV-LIgGHC9IgDTM diente als eukaryotisches Expressionsplasmid für die schwere Kette des MA18/7-Antikörpers. Das PCR-Produkt des Fusionsgens der schweren Kette mit der Transmembrandomäne LIgGHC9IgDTM wurde über die Restriktionsschnittstellen HindIII und EcoRV unter Austausch des S-Gens in das Plasmid pSVBX24H kloniert. 
pSV-LIgGHC9* (diese Arbeit)

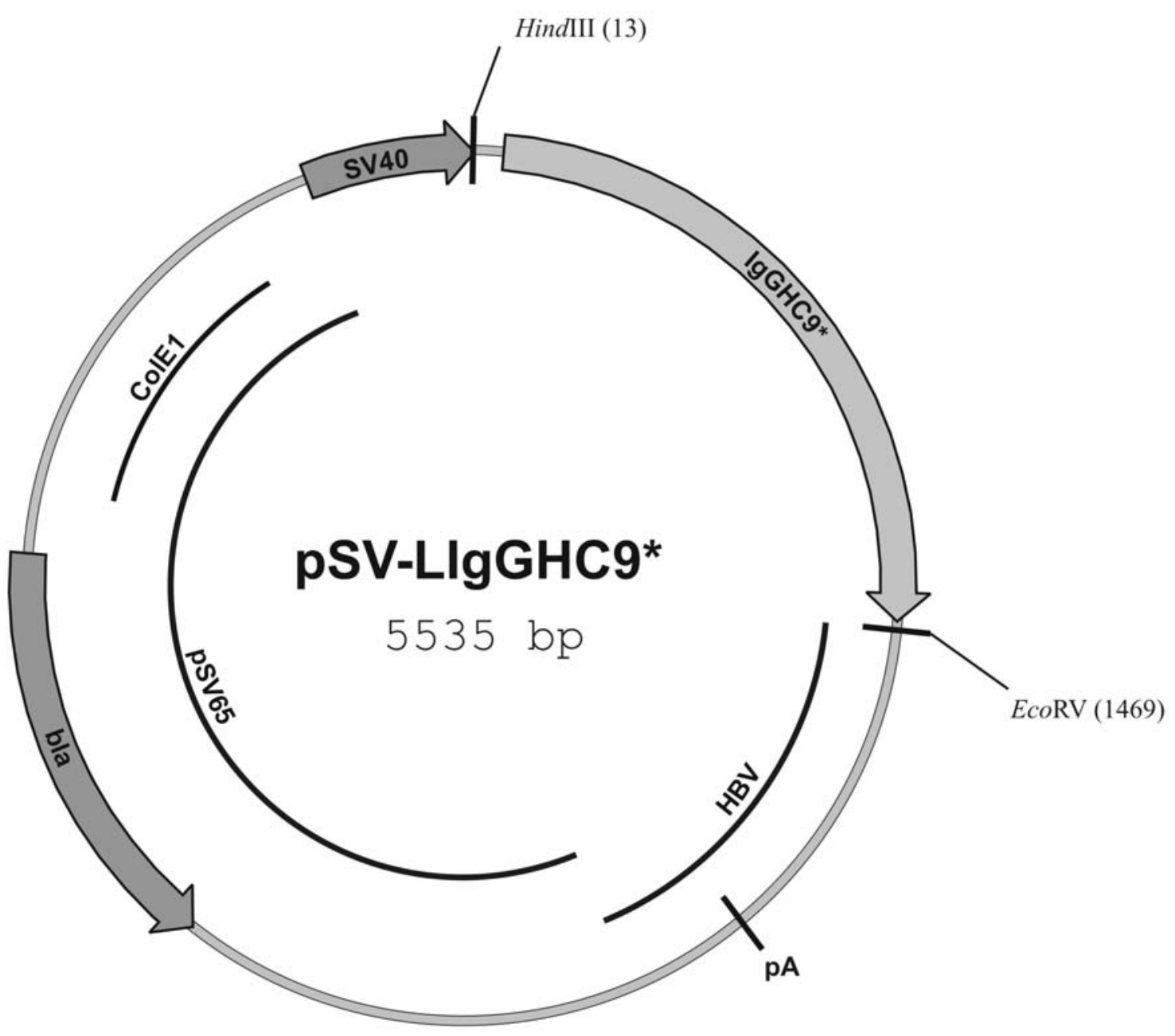

Abb. 10: Graphische Darstellung des Plasmids pSV-LIgGHC9*.

SV40: SV40-early-Promotor, IgGHC9*: Leserahmen der sekretorischen Variante der schweren Kette des MA18/7-Antikörpers, pA: HBV-Polyadenylierungssignal, bla: Gen für die $\beta$-Lactamase (vermittelt Ampicillinresistenz), ColE1: prokaryotischer Replikationsursprung.

Das Plasmid pSV-LIgGHC9* diente als eukaryotisches Expressionsplasmid für die sekretorische Variante der schweren Kette des MA18/7-Antikörpers. Die Klonierung erfolgte wie bei pSV-LIgGHC9IgDTM. 
pSV-KappaLC8d (diese Arbeit)

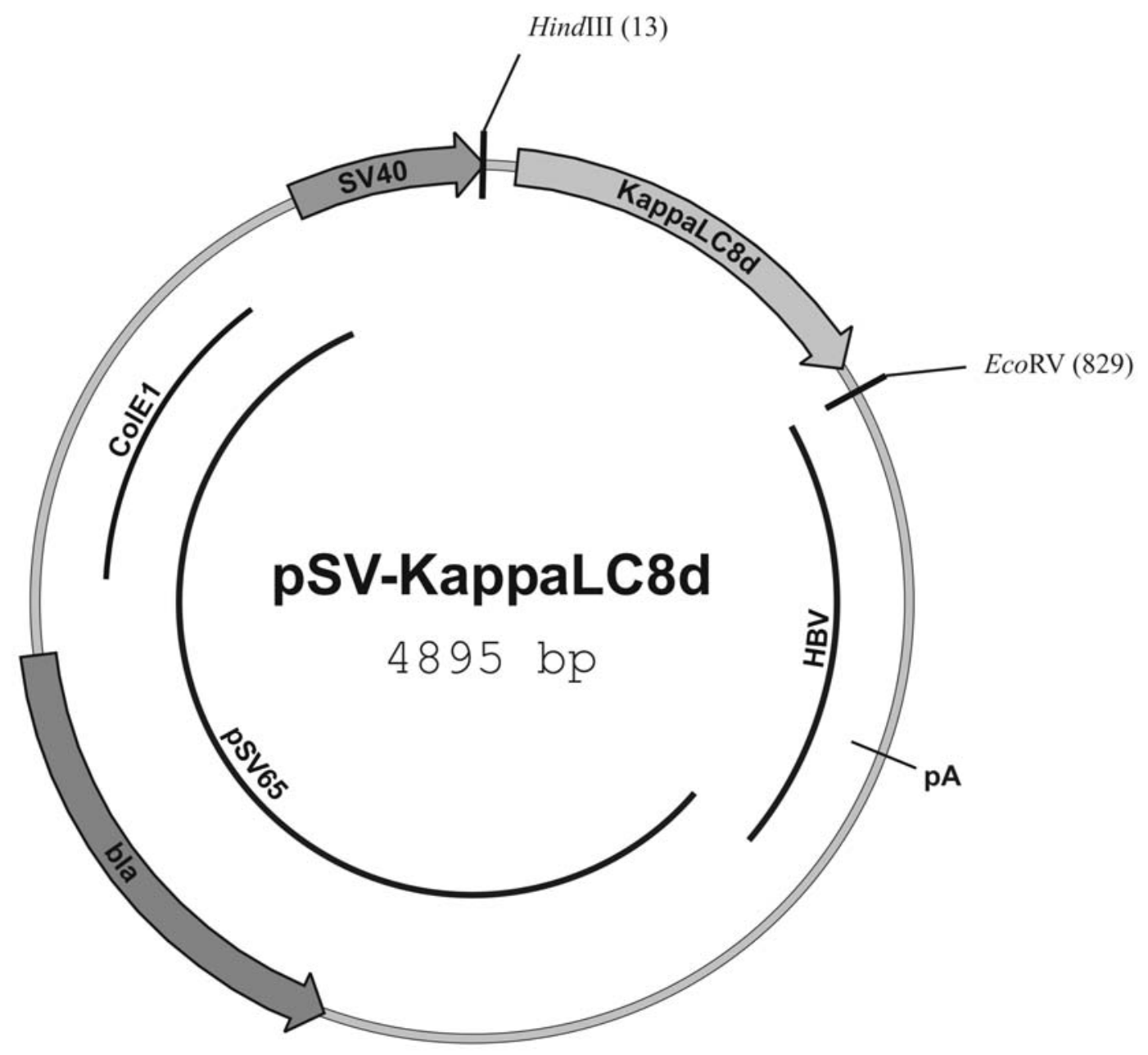

Abb. 11: Graphische Darstellung des Plasmids pSV-KappaLC8d.

SV40: SV40-early-Promotor, KappaLC8d: Leserahmen der leichten Kette des MA18/7Antikörpers, pA: HBV-Polyadenylierungssignal, bla: Gen für die $\beta$-Lactamase (vermittelt Ampicillinresistenz), ColE1: prokaryotischer Replikationsursprung.

Das Plasmid pSV-KappaLC8d diente als eukaryotisches Expressionsplasmid für die leichte Kette des MA18/7-Antikörpers. Die Klonierung erfolgte wie bei pSV-LIgGHC9IgDTM. 


\subsection{Oligonukleotide}

Nr. Bezeichnung Sequenz 5'-3'

\begin{tabular}{|c|c|}
\hline \#0162 PolyT & GGC CGA TCG GGC CGG CGC GCC TTT TTT TTT TTT TTT \\
\hline & TT \\
\hline \#0165 n74a_up & GGA TCT TCC AAA TTA GCA CCC ACC CAG G \\
\hline \#0167 n92a_lo & GTT AAT ACT GCC ATG GGT TTA AAG ATC AGG \\
\hline \#0168 i126a_lo & CGG AGT GTG GGC TCG CAC TCC TCC \\
\hline \#0169 HC9leader & ACC ATG AGA GTG CTG ATT CTT TTG TGG CTG TTC \\
\hline & ACA GGC TTT CCT GGT ATC \\
\hline \#0170 IgGHC9* & CCA GGA GAG TGG GAG AGG \\
\hline \#0171 HC9-TM & GAG AAG AGC CTC TCC CAC TCT CCT GGA GGC ATA \\
\hline & GTC AAC ACC ATC \\
\hline \#0172 IgDTMend & CTA CTT CAC CTT GAT GAA GGT GAC G \\
\hline \#0173 s21a_up & GAC GGA AGG AAA GAA GTC AGC AGG CAA AAA GC \\
\hline \#0177 sv40out & TCG GCC TCT GAG CTA TTC CA \\
\hline \#0178 core_lo & GAT TAA AGA TAG GTA CTG \\
\hline \#0179 HC9endK* & TCA TTA CCA GGA GAG TGG GAG AGG \\
\hline \#0196 e14a_up & TAG TAA CGC CAC AGT AGC \\
\hline \#0197 v27a_up & AGG AGA TCT CTG GCG GAA GGA AAG \\
\hline \#0198 i59a_up & CCC CCC AGC AGA GAG CGG CTT GCC TTA AGG \\
\hline \#0199 m66a_up & AGC TAG AGT CGC CAA TTC CCC C \\
\hline \#0200 g73a_up & CCA AAT TAT TAG CCA CCC AGG T \\
\hline \#0201 d83a_up & GAC TAC TAG AGC CCT GGA TGC \\
\hline \#0202 n90a_lo & CAA TTA TGT TGC TAC TAA CAT GG \\
\hline \#0204 f122a_lo & ATT TGG TCT CTG CCG GAG TGT GG \\
\hline \#0205 r127a_lo & GGA GTG TGG ATT GCC ACT CCT CCA GC \\
\hline \#0218 LC8dleader & ATG GAA TCA CAG ACT CTG GTC TTC ATA TCC ATA \\
\hline & TTG CTC TGG TTA TAT GGT \\
\hline \#0219 LC8Kozak & ACC ATG GAA TCA CAG ACT \\
\hline \#0226 f18a_up & CAG AAG GCA AAG CGC TTA GTA ACT CC \\
\hline
\end{tabular}




\begin{tabular}{|c|c|}
\hline$\# 0227$ d22s_up & GAC GGA AGG AAA GAA GGC AGA AGG CAA AAA GC \\
\hline \#0228 n75a_up & GGA TCT TCC AAA TCA TTA CCC ACC C \\
\hline \#0229 q77a_up & GGA TGC TGG ATC TGC CAA ATT ATT ACC \\
\hline \#0236 i140a_lo & GCC CCT ATC GCA TCA ACA CTT CC \\
\hline \#0245 k96a_lo & AAC ATG GGT TTA GCG ATC AGG CAA TTG \\
\hline \#0246 y118a_lo & GTA CTT GAA GCT TTG GTC TCT TTC G \\
\hline \#0247 1119a_lo & ACT TGA ATA TGC GGT CTC TTT CG \\
\hline \#0248 w125a_lo & CTT TCG GAG TGG CGA TTC GCA CTC C \\
\hline \#0249 r133a_lo & CCT CCA GCC TAT GCA CCA CCA AAT GC \\
\hline \#0250 a137g_lo & AGA CCA CCA AAT GGC CCT ATC TTA TC \\
\hline \#0251 i139a_lo & AGA CCA CCA AAT GCC CCT GCC TTA TCA ACA C \\
\hline \#0252 d22a_up & GAC GGA AGG AAA GAA GGC AGA AGG CAA AAA GC \\
\hline \#0253 n75a_up & GGA TCT TCC AAA TCA TTA CCC ACC C \\
\hline \#0254 q77a_up & GGA TGC TGG ATC TGC CAA ATT ATT ACC \\
\hline \#0255 s17a_up & CAG AAG GCA AAA AGG CTA GTA ACT CC \\
\hline \#0256 131a_up & GAG GCG GTG TCT GCG AGA TCT CTG \\
\hline \#0257 w62a_up & CAA TTC CCC CGC GCA GAG AAT G \\
\hline \#0258 t70a_up & ACC CAC CCA GGC AGC TAG AGT C \\
\hline \#0259 d78a_lo & AAT TTG GAA GCT CCA GCA TCC \\
\hline \#0260 p79a_lo & TTG GAA GAT GCA GCA TCC AGG \\
\hline \#0261 r82a_lo & CCA GCA TCC GCG GAT CTA GTA G \\
\hline \#0262 n87a_lo & CTA GTA GTC GCT TAT GTT AAT AC \\
\hline \#0263 t91a_lo & CAA TTA TGT TTA TGC TAA CAT GGG \\
\hline \#0264 196a_lo & ACT AAC ATG GGT GCA AAG ATC AGG \\
\hline \#0265 r98a_lo & GGG TTT AAA GAT CGC GCA ATT GTT G \\
\hline \#0266 v13a_up & TAG TAA CTC CGC AGT AGC TCC \\
\hline \#0267 s26a_up & CTC TGA CGG CAG GAA AGA AG \\
\hline \#0268 r28a_up & CTA GGA GAT CTG CGA CGG AAG GAA AG \\
\hline \#0269 d32a_up & GAG CGG TGG CTA GGA GAT C \\
\hline \#0270 160a_up & CCC CCC AGC AGG CAA TGG CTT GCC \\
\hline \#0271 t67a_lo & AGC TAG AGC CAT CAA TTC CCC \\
\hline \$0272 176a_lo & GCT GGA TCT TCC GCA TTA TTA CCC \\
\hline
\end{tabular}




\begin{tabular}{|c|c|}
\hline \#0273 a80g_up & AGA TCC CTG GAT CCT GGA TCT TCC \\
\hline \#0274 p129a_lo & GGA TTC GCA CTG CTC CAG CCT ATA G \\
\hline \#0275 p130a_lo & TCG CAC TCC TGC AGC CTA TAG ACC \\
\hline \multirow[t]{2}{*}{ \#0276 nne_up } & GGA TGC TGG ATC TGC CAA AGC AGC ACC CAC CCA \\
\hline & GG \\
\hline \multirow[t]{2}{*}{ \#0277 nep_up } & CCC TGG ATG CTG CAT CTG CCA AAT TAG CAC CCA \\
\hline & CCC AGG \\
\hline \#0282 184a_up & AAT TGA CTA CTG CAT CCC TGG ATG C \\
\hline \#0284 core_lo & GAA GGA GTT TGC CAT TCA GG \\
\hline \#0290 d2a_up & AAG GGT CAA TGG CCA TGC CCC GG \\
\hline \#0291 d4a_up & CTT TAT AAG GGG CAA TGT CCA TGC \\
\hline \#0292 p20a_up & GAA GTC AGA AGC CAA AAA GCT TAG \\
\hline \#0293 d29a_up & GTC TAG GAG AGC TCT GAC GGA AGG \\
\hline \#0294 a131g_lo & CGC ACT CCT CCA GGC TAT AGA CCA CC \\
\hline \#0295 p135a_lo & CCA GCC TAT AGA CCA GCA AAT GCC CC \\
\hline \#0296 n136a_lo & ATA GAC CAC CAG CTG CCC CTA TC \\
\hline
\end{tabular}

\subsection{Antikörper}

anti-HBc (DAKO, Hamburg)

anti-HBc, polyklonales Kaninchen-Serum

anti-HBs (DAKO, Hamburg)

anti-HBs, polyklonales Ziegen-Serum

F1451 (Abt. Virologie, Universität Göttingen)

antiHBc/e, polyklonales Serum, Mensch

anti-Maus Ig (DAKO, Hamburg)

anti-Ig Maus, polyklonales Kaninchen-Serum 
anti-Maus, Peroxydase-konjugiert (DAKO Hamburg)

anti-Ig Maus, polyklonales Kaninchen-Serum, Peroxydase konjugiert

anti-HBc-konjugiert (Abt. Virologie, Universität Göttingen)

POD-Konjugat, Schaf

anti-Maus, Cy2-konjugiert (Dianova, Hamburg)

anti-Maus $\operatorname{IgG}(\mathrm{H}+\mathrm{L})$, Cy2-markiertes $\mathrm{F}(\mathrm{ab})_{2}$-Fragment, Esel

anti-stat1 (Transduction Laboratories, Hamburg)

Maus anti-stat1

anti-Ziege Ig, Cy3-konjugiert (Dianova, Hamburg)

\subsection{DNA-Längenstandards}

$\lambda$-DNA BstEII-verdaut (New England Biolabs, Schwalbach):

$8454 b p-7242 b p-6369 b p-5686 b p-4822 b p-4324 b p-3675 b p-2323 b p-$ $1929 b p-1371 b p-1264 b p-701 b p-244 b p-117 b p$

100bp DNA Ladder Plus (MBI Fermentas, Vilnius, Litauen)

$3000 b p-2000 b p-1500 b p-1200 b p-1031 b p-900 b p-800 b p-700 b p-600 b p-$ $500 b p-400 b p-300 b p-200 b p-100 b p$ 


\subsection{Radionuklide}

$\alpha^{32}$ P-dCTP (NEN, Bad Homburg), spez. Aktivität 3000 Ci/mmol

${ }^{35}$ S Protein labeling Mix (NEN, Bad Homburg), spez. Aktivität $1200 \mathrm{Ci} / \mathrm{mmol}$

${ }^{14}$ C-methylierter Rainbow Protein-Marker (Amersham Pharmacia Biotech, Freiburg)

\subsection{Lösungen und Puffer}

\section{Blotpuffer für Western-Blot}

0,192 M Glycin, 25 mM Tris, 15 \% (v/v) Methanol

\section{Coating-Puffer}

15,5 mM Na-Phosphat $\mathrm{pH} 7,6$

\section{Coomassie Entfärbelösung}

$10 \%(\mathrm{v} / \mathrm{v})$ Methanol, $5 \%(\mathrm{v} / \mathrm{v})$ Acetat

\section{Coomassie Färbelösung}

$50 \%(\mathrm{v} / \mathrm{v})$ Methanol, $10 \%$ (v/v) Acetat, 0,1\% (w/v) Coomassie Brillant Blau

\section{COS-Lysispuffer}

$150 \mathrm{mM} \mathrm{NaCl}, 50 \mathrm{mM}$ Tris/Cl pH 7,5, $5 \mathrm{mM} \mathrm{MgCl}$, 0,2 \% (v/v) NP40

\section{DEAE-Dextran/Chloroquin}

$10 \mathrm{mg} / \mathrm{ml}$ DEAE-Dextran, 2,5 mM Chloroquin

\section{Denaturierungslösung für Southern-Blot}

$0,5 \mathrm{M} \mathrm{NaOH}, 1,5 \mathrm{~m} \mathrm{NaCl}$ 


\section{HEPES-Puffer ( $2 x)$}

$50 \mathrm{mM}$ Hepes, $280 \mathrm{mM} \mathrm{NaCl}, 1,5 \mathrm{mM} \mathrm{NAH}_{2} \mathrm{PO}_{4}$ mit NaOH auf $\mathrm{pH}$ 7,1 eingestellt

\section{Laufpuffer (10 x) für SDS-PAGE}

0,25 M Tris, 1,92 M Glycin, $1 \%$ (v/v) SDS

\section{Lösung I (Plasmidpräparation)}

$50 \mathrm{mM}$ Glucose, $25 \mathrm{mM}$ Tris/Cl pH 8,0, $10 \mathrm{mM}$ EDTA

\section{Lösung II (Plasmidpräparation)}

$0,2 \mathrm{~N} \mathrm{NaOH}, 1 \%(\mathrm{w} / \mathrm{v}) \mathrm{SDS}$

\section{Lösung III (Plasmidpräparation)}

$3 \mathrm{M} \mathrm{K}^{+}, 5 \mathrm{M} \mathrm{Acetat}^{-}$, mit Eisessig auf $\mathrm{pH}$ 5,5 eingestellt

\section{Lösung IV (Plasmidpräparation)}

$13 \%$ (w/v) Polyethylenglykol 6000, 1,6 M NaCl

\section{Lysispuffer zur ccc-DNA-Isolierung aus Zellkulturen}

$50 \mathrm{mM}$ Tris/Cl pH 8,0, $10 \mathrm{mM}$ EDTA, $150 \mathrm{mM} \mathrm{NaCl}, 1$ \% (w/v) SDS

\section{Milch-Puffer}

$5 \%(\mathrm{w} / \mathrm{v})$ Magermilchpulver, 0,2 \% (v/v) Tween20 in PBS

\section{Mowiol Eindeckelmedium}

$1 \%(\mathrm{w} / \mathrm{w})$ Mowiol 4-88, 19,5 \% (v/v) Glycerin, 0,1 M Tris/Cl pH 8,5

\section{Neutralisierungspuffer für Southern-Blot}

1,5 M NaCl, 0,5 M Tris/Cl $\mathrm{pH} 7,5$

\section{PBS inkomplett}

$180 \mathrm{mM} \mathrm{NaCl}, 8,5 \mathrm{mM} \mathrm{Na}_{2} \mathrm{HPO}_{4}, 2,2 \mathrm{mM} \mathrm{KH}_{2} \mathrm{PO}_{4}$ 
Probenauftragspuffer (4 x) für SDS-PAGE

$12 \%(\mathrm{w} / \mathrm{v})$ SDS, $20 \%$ (v/v) Glycerin, 0,06 \% (w/v) Bromphenolblau, 0,25 M Tris/Cl $\mathrm{pH}$ 6,8, $20 \%(\mathrm{w} / \mathrm{v})$ DTT (frisch zugegeben)

\section{Probenpuffer (6 x) für Agarosegelelektrophorese (Sucrosefarbmarker)}

$6 \times$ TAE, $0,04 \%$ (w/v) Bromphenolblau, 0,04 \% (w/v) Xylencyanol FF, $30 \%$ (v/v)

Glycerol

Proteinase-K-Puffer ( 2 x)

$2 \%(\mathrm{w} / \mathrm{v}) \mathrm{SDS}, 20 \mathrm{mM}$ Tris/Cl pH 7,5, $20 \mathrm{mM}$ EDTA

\section{Sammelgelpuffer (4 x) für SDS-PAGE}

$0,4 \%(\mathrm{w} / \mathrm{v}) \mathrm{SDS}, 0,5 \mathrm{M}$ Tris/Cl pH 6,8

\section{Substratmix für ELISA}

$100 \mathrm{mM}$ Citrat, $200 \mathrm{mM} \mathrm{Na}_{2} \mathrm{HPO}_{4}, 0,4 \mathrm{mM}$ Orthophenyldiamin

\section{TAE-Puffer (50 x)}

2 M Tris-Acetat $\mathrm{pH}$ 7,8, $50 \mathrm{mM}$ EDTA,

\section{TBE-Puffer (10 x)}

0,9 M Tris, 0,9 Borat, 20 mM EDTA pH 8,0

\section{TE-Puffer}

$10 \mathrm{mM}$ Tris/Cl pH 8,0, $1 \mathrm{mM}$ EDTA

\section{TE/RNase-Puffer}

10 mM Tris/Cl pH 8,0, 1 mM EDTA, $50 \mu \mathrm{g} / \mathrm{ml}$ RNaseA

\section{TNE-Puffer}

$100 \mathrm{mM} \mathrm{NaCl}$, 0,1 mM EDTA, $10 \mathrm{mM}$ Tris/Cl pH 8,0 


\section{Transformationspuffer I (TFB I)}

$30 \mathrm{mM}$ Kaliumacetat, $15 \%$ (w/v) Glycerin, $100 \mathrm{mM} \mathrm{KCl,} 10 \mathrm{mM} \mathrm{CaCl}_{2}, 50 \mathrm{mM}$ $\mathrm{MnCl}_{2}$ mit Essigsäure auf $\mathrm{pH}$ 5,8 eingestellt

\section{Transformationspuffer II (TFB II)}

$10 \mathrm{mM}$ 3-(N-Morpholino)propansulfonsäure (MOPS), $75 \mathrm{mM} \mathrm{CaCl}_{2}, 10 \mathrm{mM} \mathrm{KCl}$, $15 \%(\mathrm{v} / \mathrm{v})$ Glycerin

\section{Tenngelpuffer (4 $\mathrm{x})$ für SDS-PAGE}

1,5 M Tris/Cl pH 8,8, 0,1 \% (w/v) SDS

\section{Waschpuffer A für Southern-Blot}

$2 \mathrm{M}$ Harnstoff, 0,1\% (w/v) SDS, $50 \mathrm{mM} \mathrm{NaH}_{2} \mathrm{PO}_{4} \mathrm{pH}$ 7,0, $150 \mathrm{mM} \mathrm{NaCl}, 10 \mathrm{mM}$ $\mathrm{MgCl}_{2}$

\section{Waschpuffer B für Southern-Blot}

$50 \mathrm{mM}$ Tris/Cl pH 10,0, $100 \mathrm{mM} \mathrm{NaCl}, 2 \mathrm{mM} \mathrm{MgCl} 2$

\subsection{Laborgeräte und Materialien}

Autoradiographie-Film BIOMAX MR, Kodak, New Haven, USA

Brutschrank $\mathrm{CO}_{2}$-Auto-Zero, Hera Cell 240, Heraeus, Hanau

Elektroblot-Kammer, Biorad, München

ELISA-Plattenwaschgerät, Dynatech, Deckendorf

Feinwaage Handy, Sartorius, Göttingen

Geldokumentation

analog: Sofortbildphotographie

Orangefilter Hoya G, Polaroid, Herts, GB

Polaroid-Filme Typ 667, Polaroid, Herts, GB 
Polaroid-Sofortbildkamera-System, Polaroid, Herts, GB

Ultraviolett-Schirm, Kodak, Rochester, USA

Chroma $41(254 \mathrm{~nm})$

digital: Geldokumentation

Gel Jet Imager 2000, INTAS, Göttingen

Gelkassette, Biorad, München

Geltrockner, Biotec Fischer, Reiskirchen

Grobwaage Universal, Sartorius, Göttingen

Hochvakuumpumpe, Leybold Heraeus, Osterode

Kühlfalle, Leybold Heraeus, Osterode

Hybridisierungsbeutel, GIBCO BRL, Eggenstein

Hybridisierungsofen „Mini 10“, Hybaid, Heidelberg

Laufkammer für Agarosegelelektrophoresen, Eigenbau

Laufkammer für Polyacrylamidgelelektrophoresen, Eigenbau

Vertikalelektrophorese-System, Hofer Sci, Ins., Heidelberg

mighty small tall SE 280T, Hofer Sci, Ins., Heidelberg

K-Screen, Biorad, München

Magnetrührer, IKA Schütt, Göttingen

Mikroskop „Telaval 31“, Zeiss, Jena

Mikroskop „Leica DMR“, Leica, Wetzlar

Neubauer-Zählkammer, Zeiss, Jena

pH-Meter Mettler Toledo MP225, Merck Labor, Dietikon, CH

Phosphoimager Molecular Imager FX, Biorad, München

Probenmischer (Vortexgerät), Bender und Hobein, $\mathrm{CH}$

Refraktometer, Zeiss, Jena 
Schüttler Lab-Shaker, Braun, Melsungen

Sequenziergerät ABI 373 A DNA-Sequencer, Applied Biosystems, Weiterstadt Spannungsgerät E883, Peqlab, Erlangen

Spektralphotometer DU70, Beckmann, München

Sterilbank „HERAsafe“, Heraeus, Hanau

Tischinkubator, Eppendorf, Hamburg

Transblot-Zelle TE mighty small Transphor, Hofer Sci, Ins., Heidelberg

Thermo-Cycler „GeneAmp PCR System 9600“, Perkin Elmer, Norwalk, USA

Überkopfroller, Test-Tube Rotator, Snijders, Tilburg, NL

Wasserbad, GFL Burgwedel

Zentrifugen

Eppendorf Tischzentrifuge C5415, Eppendorf, Hamburg

Kühlzentrifuge 5402, Eppendorf, Hamburg

Kühlzentrifuge RC 26 plus, Sorvall, Bad Homburg

Rotor SLA-3000, Sorvall, Bad Homburg

Rotor SA 300, Sorvall, Bad Homburg

Kühlzentrifuge Universal 30RF, Hettich, Tuttlingen 


\subsection{Chemikalien}

Soweit nicht anders vermerkt, wurden alle Chemikalien von den Firmen Merck (Darmstadt), Peasel \& Lorei (Frankfurt), Serva (Heidelberg) und Sigma (Steinheim) bezogen.

Acrylamid-Lösung, Applichem, Darmstadt

Adenosintriphosphat, Roche, Mannheim

Agarose, Peqlab, Erlangen

Bacto-Hefeextrakt, Becton-Dickinson, Franklin Lakes, USA

Bacto-Trypton, Becton-Dickinson, Franklin Lakes, USA

Biodyne B Nylon Membran, Pall, Portsmouth, GB

Desoxynukleotide, Roche, Mannheim

Entwickler, Kodak, New Haven, USA

Fixierer, Kodak, New Haven, USA

Immobilon-Membran PVDF, Milliopore, Bedford, USA

Milchpulver, Glücksklee

Mowiol 4-88, Calbiochem, La Jolla, USA

Prism Ready Reaction DyeDeoxy Terminator Cycle Sequencing Kit, Applied Biosystems, Weiterstadt 


\section{METHODEN}

\subsection{Molekularbiologische Methoden}

\subsubsection{Vorbereitung von Lösungen und Arbeitsgeräten}

Hitzestabile Geräte und Lösungen wurden durch Erhitzen für 20 Minuten auf $121^{\circ} \mathrm{C}$ autoklaviert. In der Hitze nicht beständige Geräte wurden mit $70 \%$ (v/v) Ethanol gereinigt und getrocknet. Hitzelabile Bestandteile von Lösungen wurden als konzentrierte Stammlösungen hergestellt und vor der Zugabe zu bereits sterilen Lösungen durch einen Membranfilter der Porengröße von 0,2 $\mu \mathrm{m}$ sterilfiltriert.

\subsubsection{DNA-Arbeiten mit Enzymen}

\subsubsection{Polymerase-Kettenreaktion (SAIKI et al., 1985)}

Die Polymerase-Kettenreaktion (PCR) erlaubt es, in vitro Sequenzbereiche, die flankierend durch zwei definierte Oligonukleotide eingegrenzt werden, selektiv aus einem Sequenzgemisch von Ausgangs-DNA zu amplifizieren. Der Anspruch an die als Matrize verwendete DNA ist dabei sehr gering. So könnte sowohl aufgereinigte Plasmid-DNA als auch genomische DNA lysierter Zellen als Vorlage für eine PCR dienen.

Bei der Durchführung einer PCR werden gezielt durch Einstellen verschiedener Temperaturen spezifische biochemische Prozesse herbeigeführt. Grundvoraussetzung für die Polymerase-Kettenreaktion ist eine thermostabile DNA-Polymerase, wie die in E. coli rekombinant hergestellte Taq-Polymerase aus Thermus aquaticus, einem hyperthermophilen marinen Prokaryonten. Taq-Polymerase besitzt als hochthermostabiles Enzym ein Aktivitätsoptimum von $72{ }^{\circ} \mathrm{C}$. 
Das Endvolumen eines PCR-Ansatzes fasste $50 \mu 1$, wobei meist mehrere Ansätze parallel durchgeführt wurden, was gleichzeitig die Pipettiergenauigkeit erhöhte. Für den Einsatz von Taq-Polymerase enthielt ein PCR-Ansatz jeweils 5-10 ng DNA als Matrize, 0,2 $\mu \mathrm{M}$ eines jeden Oligonukleotids, $200 \mu \mathrm{M}$ dNTP Mix, sowie TaqPolymerase-Puffer mit $\mathrm{MgCl}_{2}$-Konzentrationen zwischen $1 \mu \mathrm{M}$ und $5 \mu \mathrm{M}$ und $1 u$ TaqPolymerase. Der Rest des Ansatzes wurde mit Wasser aufgefüllt. Alternativ wurden PCR-Ansätze mit Tfl-Polymerase durchgeführt, die ein eigenes Puffersystem benötigten.

Für das Einstellen der nachfolgend aufgeführten Zyklen an Temperaturen wurde der Thermocycler GeneAmp PCR System 9600 der Firma Perkin Elmer benutzt.

Im ersten Schritt eines fertigen PCR-Ansatzes wird durch Denaturierung bei $96{ }^{\circ} \mathrm{C}$ die doppelsträngige Matrizen-DNA aufgetrennt und Einzelstränge produziert. Durch Herabsetzen der Temperatur wird im nächsten Schritt neben der Renaturierung beider DNA-Stränge eine Anlagerung der Oligonukleotide als Konkurrenzreaktion erreicht. Die annealing-Temperatur der Oligonukleotide ist hierbei spezifisch von der Länge und den Bindungskräften der Wasserstoffbrückenbindungen der Basenpaarungen (GCGehalt) abhängig und berechnet sich wie folgt unter Berücksichtigung der Schmelztemperatur:

$$
\mathrm{T}_{\mathrm{M}}\left[{ }^{\circ} \mathrm{C}\right]=69,3+0,41 \cdot(\% \mathrm{G} / \mathrm{C})-\frac{650}{\mathrm{n}}
$$

Aus (1) berechnet sich die Schmelztemperatur der Oligonukleotide, die in der Regel zwischen $45^{\circ} \mathrm{C}$ und $60{ }^{\circ} \mathrm{C}$ gelegen haben. Aus der Schmelztemperatur beider Oligonukleotide errechnet sich die annealing-Temperatur wie folgt:

$$
\mathrm{T}_{A}\left[{ }^{\circ} \mathrm{C}\right]=\frac{\left(\mathrm{T}_{\mathrm{M} 1}+\mathrm{T}_{\mathrm{M} 2}\right)}{2}-3^{\circ} \mathrm{C}
$$

wobei $\mathrm{T}_{\mathrm{M} 1}$ und $\mathrm{T}_{\mathrm{M} 2}$ die Schmelztemperaturen der zwei eingesetzten Oligonukleotide sind. Nach Anlagerung der Oligonukleotide kommt es zum PolymeraseOligonukleotidkomplex, so dass trotz Anheben der Temperatur auf $72{ }^{\circ} \mathrm{C}$ für die nachfolgende Elongationsphase die Oligonukleotide auf dem Matrizenstrang stabilisiert 
bleiben. Die Dauer der Elongationsphase orientiert sich an der Länge des zu amplifizierenden DNA-Abschnittes. Als Richtwert werden bei Verwendung der TaqPolymerase 60 Sekunden pro 1000 Basenpaare veranschlagt. Zum Starten eines neuen Zyklus wird der Ansatz erneut zur Denaturierung auf $96^{\circ} \mathrm{C}$ erhitzt. Die Anzahl der amplifizierten Sequenzabschnitte nimmt exponentiell mit jedem Zyklus zu. Nach 25 Zyklen sollte ausreichend PCR-Produkt amplifiziert worden sein, wobei sich ein Ende der Reaktion mit der Erschöpfung der eingesetzten Desoxynukleotide meist schon früher einstellt.

\subsubsection{Spaltung von DNA mit Hilfe von Restriktionsendonukleasen}

Die Spaltung von DNA durch Restriktionsendonukleasen (Restriktionsenzymen) dient sowohl als präparatives Hilfsmittel für Klonierungszwecke als auch analytischen Zwecken zur Identifikation von Restriktionsschnittstellen, beispielsweise zur Identifikation von Plasmiden und zur Kontrolle nach Klonierungen. Endonukleolytische Spaltungen von Restriktionsenzymen sind äußerst sequenzspezifisch und unterliegen individuellen Reaktionsbedingungen. So hat jedes Restriktionsenzym eine eigene, meist palindromische Erkennungssequenz, die unter optimalen Pufferbedingungen und Inkubationstemperatur geschnitten wird. Die Inkubationsdauer richtet sich nach der Temperatur, der Menge an eingesetzter DNA und der Menge eingesetzten Enzyms. Bei optimalen Bedingungen spaltet eine Einheit $\left[\begin{array}{ll}1 & u\end{array}\right]$ Restriktionsenzym $1 \mu \mathrm{g}$ DNA in einer Stunde.

Meist zeigte ein Restriktionsenzym in mehreren der vier vom Hersteller gelieferten Puffersystemen Aktivität, die jedoch häufig im Vergleich zum optimalen Puffer geringer war. Insbesondere analytische Spaltungen konnten so zeitsparend mit zwei verschiedenen Restriktionsendonukleasen gleichzeitig stattfinden, sofern beide Enzyme befriedigende Kompatibilität für einen Puffer zeigten. Für präparative Zwecke empfahl es sich, mit dem Ziel einer nahezu vollständigen Spaltung, einzeln und nacheinander zu spalten, um so auch den Erfolg jeder einzelnen Spaltung verifizieren zu können. Zwischen den Spaltungen wurde die DNA durch Phenol/Chloroform-Extraktion (3.1.4.1) aufgereinigt und ethanolgefällt (3.1.4.2). 
Für analytische Spaltungen wurden $2-3 \mu 1$ der DNA mit $2 \mu 110$ x Puffer und ca. 0,5 Einheiten Enzym gemischt. Das Endvolumen betrug $20 \mu 1$ und wurde mit Wasser aufgefüllt. Bei präparativen Spaltungen wurden zwischen $1 \mu \mathrm{g}$ und $10 \mu \mathrm{g}$ DNA eingesetzt, wobei pro Mikrogramm DNA drei Einheiten Enzym eingesetzt wurden. Optimale Aktivität einiger Enzyme erforderte zusätzliche Sublimierung von BSA. Das Ergebnis einer Spaltung ließ sich auf einem Agarosegel analysieren (3.1.4.6).

\subsubsection{Ligation von DNA-Fragmenten}

Zur Ligation von einem PCR-amplifizierten Gen mit Plasmid-DNA wurde mit kompatiblen Restriktionsendonukleasen geschnittene DNA eingesetzt, wobei die geschnittene Insert-DNA gegenüber dem geschnittenen Plasmid in einem mehrfachen Überschuss vorhanden sein sollte. Das Endvolumen eines Ligationsansatzes betrug meist $20 \mu \mathrm{l}$ und beinhaltete neben der DNA $2 \mu 1$ T4-Ligasepuffer $(10 \mathrm{x}), 2 \mu 1$ BSA $(10 \mathrm{x})$ sowie 2 Einheiten T4-DNA-Ligase. Die Ligation erfolgte optimalerweise über Nacht bei $14{ }^{\circ} \mathrm{C}$ im Kühlbad. Alternativ wurde der Ansatz für 3 Stunden bei $30^{\circ} \mathrm{C}$ inkubiert. Nach Phenol/Chloroform-Extraktion (3.1.4.1) und Ethanolfällung (3.1.4.2) konnte das Ligationsprodukt direkt zur Transformation (3.2.3) in kompetente E. coliZellen verwendet werden.

\subsubsection{Auffüllen von überhängenden DNA-Enden}

Zum Auffüllen von überhängenden DNA-Enden nach Spaltung mit Restriktionsendonukleasen wurde T4-DNA-Polymerase verwendet. Die bei Raumtemperatur und unter Anwesenheit von $250 \mu \mathrm{M}$ dNTPs stattfindende Polymerisation wurde nach 30 Minuten durch Entfernung der T4-Polymerase mittels Phenol/Chloroform-Extraktion (3.1.4.1) beendet. 


\subsubsection{DNA-Präparation aus $E$. coli}

\subsubsection{Isolierung von Plasmid-DNA im analytischen Maßstab (alkalische Lyse nach BIRNBOIM und DOLY, 1979 modifiziert)}

$1,5 \mathrm{ml}$ der plasmidtragenden E. coli-Übernachtkultur wurden in einem 1,5 ml Eppendorf-Reaktionsgefäß 1 Minute abzentrifugiert, der Überstand wurde verworfen. Das Zellpellet wurde anschließend in $100 \mu 1$ Lysispuffer (50 mM Glucose; 25 mM Tris$\mathrm{HCl}$ pH 8,0; 10 mM EDTA) resuspendiert und zur alkalischen Lyse mit $200 \mu 1$ MiniLösung II (0,2 N NaOH; 1 \% (w/v) SDS) versetzt.

Nach 5 Minuten Inkubation bei Raumtemperatur wurde der Ansatz durch $150 \mu 1$ MiniLösung III ( $3 \mathrm{M} \mathrm{K}^{+} ; 5 \mathrm{M}$ Acetat $\mathrm{pH}$ 5,5) neutralisiert und zur Fällung der Proteine und chromosomaler DNA für 10 Minuten auf Eis inkubiert. Nach Zentrifugation für 10 Minuten in der Tischzentrifuge wurde der Plasmid enthaltende wässrige Überstand durch Phenol/Chloroform-Extraktion (3.1.4.1) gereinigt und die DNA mit 2 Volumen Ethanol gefällt (3.1.4.2).

\subsubsection{Isolierung von Plasmid-DNA im analytischen Maßstab unter Verwendung des Qiagen-Mini-Spin-Plasmid-Prep-Kit}

Auch diese Aufreinigung basiert auf dem Prinzip der alkalischen Lyse, jedoch wird die DNA-enthaltende Lösung über eine Anionenaustausch-Matrix aufgereinigt, ist wesentlich reiner und überwiegend zur Aufreinigung von DNA verwendet worden, die anschließend sequenziert werden sollte.

1,5-2 ml plasmidtragende E. coli-Übernachtkultur wurden in Eppendorf-Reaktionsgefäßen eine Minute in einer Tischzentrifuge abzentrifugiert und der Überstand verworfen. Das Zellpellet wurde in $150 \mu 1$ Lösung I resuspendiert und zur alkalischen Lyse mit $150 \mu$ l Lösung II versetzt. Nach 5 Minuten Inkubation bei Raumtemperatur neutralisierte man den Ansatz mit $300 \mu$ Lösung III. Nach Zentrifugation der Lösung gab man den klaren Überstand auf eine Mini-Spin-Säule, wobei die Lösungen durch Zentrifugation (1 min, $14000 \mathrm{rpm}$, RT) die Säule passierten. Anschließend wurde die Säule mit $700 \mu 1$ TB-Puffer gewaschen. Die an der Säule gebundene Plasmid-DNA 
wurde anschließend mit $50 \mu \mathrm{l}$ Wasser eluiert und in einem neuen EppendorfReaktionsgefäß aufgefangen.

\subsubsection{Isolierung von Plasmid-DNA im präparativen Maßstab (alkalische Lyse nach BIRNBOIM und DOLY, 1979 modifiziert)}

Die nachfolgend beschriebene Methode eignete sich, um bis zu 3 mg Plasmid-DNA aus einer $30 \mathrm{ml}$ E. coli-Kultur hochrein für Zellkulturexperimente zu gewinnen.

Hierfür wurde $30 \mathrm{ml}$ ampicillinversetztes TB-Medium von einer Platte oder aus einer Übernachtkultur angeimpft und für 12 Stunden bei $37^{\circ} \mathrm{C}$ und $110 \mathrm{rpm}$ auf dem Schüttler inkubiert.

Nach Zentrifugation der Kultur in einem Falcon-Röhrchen für 15 Minuten bei 5000 rpm und $4{ }^{\circ} \mathrm{C}$ (Hettich 30RF, Tuttlingen) wurde der Überstand verworfen und das Zellpellet in $5 \mathrm{ml}$ Lysispuffer resuspendiert (50 mM Glucose; $25 \mathrm{mM}$ Tris- $\mathrm{HCl} \mathrm{pH} \mathrm{8,0;10} \mathrm{mM}$ EDTA). Es folgte eine alkalische Lyse durch Zugabe von $10 \mathrm{ml}$ frisch angesetzter Lösung II (0,2 N NaOH; 1 \% (w/v) SDS) und Inkubation des Ansatzes für 5 Minuten bei Raumtemperatur. Nach Zugabe von 7,5 ml Lösung III (3 $\mathrm{M} \mathrm{K}^{+} ; 5 \mathrm{M}$ Acetat pH 5,5), kräftigem Schütteln und anschließender Inkubation für 5 Minuten auf Eis kommt es zum Ausfällen genomischer DNA und zur Renaturierung episomaler DNA. Der Ansatz wurde dann für 15 Minuten bei $5000 \mathrm{rpm}$ und $4{ }^{\circ} \mathrm{C}$ abzentrifugiert. Es folgte die erste DNA-Fällung des klaren Überstandes durch Zugabe von 13,5 ml Isopropanol, Inkubation für 5 Minuten auf Eis und Zentrifugation für 15 Minuten bei $5000 \mathrm{rpm}$ bei $4{ }^{\circ} \mathrm{C}$. Das resultierende Pellet wurde in $3 \mathrm{ml}$ TE-Puffer resuspendiert, für eine RNAFällung mit $3 \mathrm{ml} 5 \mathrm{M} \mathrm{LiCl},-20^{\circ} \mathrm{C}$ versetzt und anschließend für 15 Minuten bei 5000 rpm und Raumtemperatur abzentrifugiert. Der DNA-enthaltende Überstand wurde nachfolgend durch Hinzugabe des gleichen Volumens Isopropanol für 15 Minuten bei Raumtemperatur gefällt und für 15 Minuten bei 5000 rpm und Raumtemperatur zentrifugiert. Nach Trocknen des so gewonnenen DNA-Pellets wurde dieses anschließend in $1 \mathrm{ml}$ TE-Puffer resuspendiert. Die Zugabe von $1 \mu \mathrm{TE} / \mathrm{RNaseA}$ und Inkubation für eine Stunde bei Raumtemperatur sorgte für einen Verdau restlicher RNA. Eine letzte DNA-Fällung folgte durch Zugabe von $1 \mathrm{ml}$ Lösung IV (13\% PEG; 1,6 M $\mathrm{NaCl}$ ) und Zentrifugation für 5 Minuten bei $14000 \mathrm{rpm}$ in einer Tischzentrifuge. Das 
DNA-Pellet wurde anschließend in $400 \mu 1$ TE-Puffer resuspendiert. Als letztes folgte eine dreimalige Phenol/Chloroform-Extraktion und eine Ethanolfällung. Die DNA wurde dann auf Menge und Reinheit bei $260 \mathrm{~nm}$ und $280 \mathrm{~nm}$ im Photometer (Beckmann DU70 Spektralphotometer) vermessen.

\subsubsection{Isolierung von Plasmid-DNA im präparativen Maßstab unter Verwendung des Qiagen-Plasmid-Maxi-Prep-Kit}

Die hier beschriebene Methode diente als Alternative zur in 3.1.3.3 beschriebenen Plasmidaufreinigungsmethode.

Es wurde $100 \mathrm{ml}$ ampicillinversetztes LB-Medium von einer Platte oder aus einer Übernachtkultur angeimpft und für 12 Stunden bei $37^{\circ} \mathrm{C}$ und $110 \mathrm{rpm}$ auf dem Schüttler inkubiert. Die Kultur wurde in zwei $50 \mathrm{ml}$ Sarstedt-Röhrchen überführt und für 15 Minuten bei $5000 \mathrm{rpm}$ und $4{ }^{\circ} \mathrm{C}$ abzentrifugiert. Die Pellets wurden in je $5 \mathrm{ml}$ Qiagen-Puffer-P1 des Kits resuspendiert und daraufhin in einem Gefäß vereinigt. Zugabe von $10 \mathrm{ml}$ Puffer-P2 und vorsichtiges Schwenken führte zur Lyse der Zellen. Durch anschließende Hinzugabe von $10 \mathrm{ml}$ Puffer-P3 wurden zelluläre Proteine und genomische DNA ausgefällt. Es folgte ein Inkubationsschritt über 5 Minuten auf Eis mit anschließender Zentrifugation über 15 Minuten bei $5000 \mathrm{rpm}$ und $4{ }^{\circ} \mathrm{C}$.

Der klare Überstand des Zentrifugats wurde auf eine mit $10 \mathrm{ml}$ Puffer-QBT äquibrillierte Qiagensäule gegeben, wo er ohne zusätzliche Zentrifugationskräfte die Säulenmatrix passierte. Plasmid-DNA sollte spezifisch an der Säulenmatrix binden. Unspezifisch gebundene Zelllysatkomponenten wurden anschließend durch zweimaliges Waschen mit $30 \mathrm{ml}$ Puffer-QC entfernt. Die spezifisch an der Säule gebundene Plasmid-DNA wurde nachfolgend mit 15 ml Puffer-QF von der Säule gewaschen und anschließend mit 10,5 ml Isopropanol gefällt (3.1.4.3). Die DNA wurde anschließend auf Menge und Reinheit bei $260 \mathrm{~nm}$ und $280 \mathrm{~nm}$ im Photometer (Beckmann DU70 Spektralphotometer) vermessen (3.1.4.5). 


\subsubsection{Reinigung und Konzentrierung von DNA}

\subsubsection{Phenol/Chloroform-Extraktion}

Phenol/Chloroform-Extraktion stellt eine einfache DNA-Aufreinigungsmethode dar, bei der vor allem zelluläre Proteine und proteinkomplexierte genomische DNA von Plasmid-DNA abgetrennt werden. Sie wird nach Spaltungen zum Entfernen von Restriktionsenzymen, nach Ligationen zum Entfernen der Ligase und nach Plasmidpräparationen zum Entfernen restlicher zellulärer Proteine angewandt. Zur Inaktivierung restlicher Enzymaktivität empfiehlt es sich, vorher einen Denaturierungsschritt durch Inkubation für 20 Minuten bei $80{ }^{\circ} \mathrm{C}$ durchzuführen.

Die zu extrahierende DNA-Lösung wurde zunächst mit einem Volumen Phenol/Chloroform (1:1) versetzt. Kleine Volumina wurden zunächst auf mindestens $100 \mu \mathrm{l}$ mit $\mathrm{H}_{2} \mathrm{O}$ aufgefüllt. Nach intensivem Vermischen durch Vortexen wurde anschließend durch Zentrifugation (14000 rpm, 2 min, RT) wieder eine Phasentrennung erreicht. Die obere wässrige Phase enthielt die gereinigte DNA-Lösung und konnte in ein neues Reaktionsgefäß überführt werden. Die untere Phase wurde verworfen. Meistens wurde diese Prozedur dreimal wiederholt. Zum restlosen Entfernen des Phenols konnte der Ansatz anschließend nochmals mit einem größeren Volumen Chloroform extrahiert werden. Es folgte meist eine Ethanol-Fällung zum Einkonzentrieren der DNA (3.1.4.2).

\subsubsection{Ethanol-Fällung von DNA-Lösungen}

Zur Einkonzentrierung von DNA sowie zum Wechsel von Inkubationspuffer wurde die DNA-enthaltende Lösung mit 1/10 Volumen 7 M Ammoniumacetat oder 3 M Kalium $5 \mathrm{M}$ Acetat und 3 Volumen $96 \%$ Ethanol versetzt. Durch 20 minütige Inkubation bei $-20{ }^{\circ} \mathrm{C}$ und anschließender Zentrifugation für 15 bis 30 min bei $4^{\circ} \mathrm{C}$ und $14000 \mathrm{rpm}$ in der Kühlzentrifuge wurde die gefällte DNA pelletiert. Zum Entfernen des Ammoniumacetats wurde das DNA-Pellet anschließend mit $70 \%$ Ethanol gewaschen. Die Solvatisierung des Pellets erfolgte je nach DNA-Menge in 20 - $200 \mu$ l Wasser oder TE-Puffer. 


\subsubsection{Isopropanol-Fällung von DNA-Lösungen}

DNA lässt sich auch mit Isopropanol aus wässrigen Lösungen fällen. Bei dieser Methode werden vergleichsweise weniger Salze präzipitiert als bei der Ethanolfällung. Es wurde nach gleichem Protokoll verfahren wie in Abschnitt 3.1.4.2, wobei lediglich 0,7 bis 1 Volumen Isopropanol eingesetzt wurden.

\subsubsection{Isolierung von DNA aus Agarosegelen mit dem Qiagen-Gel-Extraction-Kit}

Zur Isolierung von DNA-Fragmenten bot das Qiagen-Gel-Extraction-Kit die Möglichkeit, DNA-Fragmente nach Auftrennung und Isolierung aus Agarosegelen aufzureinigen. Vorab wurde die Gesamtmenge eines präparativen DNA-Spaltansatzes auf ein $1 \%$ Agarosegel mit großen Taschen bei geringer Stromstärke aufgetrennt (3.1.4.6). Um Schäden durch UV-Strahlung zu vermeiden, wurde die zu isolierende Bande anschließend unter Vermeidung von Exposition im UV-Durchlicht mit einem sauberen Skalpell ausgeschnitten. Zu jeweils $100 \mathrm{mg}$ ausgewogener DNA-enthaltende Agarose wurden $100 \mu \mathrm{l}$ QG-Puffer zugegeben. Nach 10 minütiger Inkubation bei $50{ }^{\circ} \mathrm{C}$ sollte das Gelstück vollständig im Puffer aufgelöst sein. DNA-Fragmente, die kleiner als $500 \mathrm{bp}$ oder größer als $4 \mathrm{~kb}$ gewesen sind, erforderten eine Zugabe von einen Volumen Isopropanol. Die Lösung wurde nun auf eine QIAquick-Säule pipettiert und durch Zentrifugation für eine Minute und $14000 \mathrm{rpm}$ bei Raumtemperatur über die Säulenmatrix geschleust. Die Lösung wurde in ein Auffangröhrchen aufgefangen, die DNA sollte an der Säulenmatrix haften bleiben. Zweimaliges Waschen mit $700 \mu 1 \mathrm{PE}-$ Puffer reinigte die Säulenmatrix von unspezifisch gebundenen Substanzen. Die extrahierte DNA wurde anschließend mit $50 \mu 1 \mathrm{H}_{2} \mathrm{O}$ oder TE-Puffer von der Säule eluiert.

\subsubsection{Konzentrationsbestimmung von DNA-Lösungen}

Zur Konzentrationsbestimmung von DNA-Lösungen, insbesondere nach PlasmidPräparationen, bediente man sich der UV-Spektrophotometrie (Beckmann DU70 Spektralphotometer). Nukleinsäuren besitzen ein Absorptionsmaximum im Bereich von 
$260 \mathrm{~nm}$ Wellenlänge. Eine optische Dichte $\left(\mathrm{OD}_{260}\right)$ von 1 entspricht einer Konzentration von $50 \mu \mathrm{g}$ dsDNA/ml, $35 \mu \mathrm{g} \mathrm{RNA} / \mathrm{ml}$ oder $33 \mu \mathrm{g}$ ssDNA/ml. Es wurde in der Regel eine 200 fache Verdünnung der Lösung in einem Endvolumen von $200 \mu 1$ hergestellt und photometrisch in einer Quarzküvette gegen Wasser vermessen. Die Reinheit der DNA-Lösung konnte durch das Erstellen eines Absorptionsspektrums beurteilt werden, das bei $260 \mathrm{~nm}$ ein Absorptionsmaximum aufweisen sollte. Verunreinigung mit Protein ließ sich durch hohe Absorption bei $280 \mathrm{~nm}$ identifizieren. Charakteristisch für eine saubere DNA-Lösung war ein Wert des Quotienten $260 \mathrm{~nm} / 280 \mathrm{~nm}$ nahe 2 .

\subsubsection{DNA-Elektrophorese im Agarosegel}

Zum Auftrennen von doppelsträngigen DNA-Fragmenten nach Restriktionsverdau sowie zur Beurteilung der Produktgrößen von PCR-Reaktionen, wurde eine geringe Menge an DNA durch Gelelektrophorese auf einem Agarosegel aufgetrennt. Je nach Größe der zu erwartenden Fragmente wurden Konzentrationen zwischen 0,8 \% (w/v) und $2 \%(\mathrm{w} / \mathrm{v})$, meist $1 \%(\mathrm{w} / \mathrm{v})$ Agarose in TBE- bzw. TAE-Puffer gewählt. Für analytische Gele wurden Gelschalen der Größe $100 \times 7 \times 0,5 \mathrm{~mm}$ mit schmalen Gelkämmen, für präparative Gele hingegen Gelschalen der Größe 125 x 80 x 7,5 mm und Kämmen mit höherem Geltaschenvolumen benutzt. Zum Herstellen der Gellösung wurde entsprechend der Konzentration Agarose und Puffer eingewogen und in einer Mikrowelle bis zur vollständigen Lösung der Agarose aufgekocht. Zum Anfärben der DNA wurde nach Abkühlen auf ca. $60^{\circ} \mathrm{C}$ Ethidiumbromid $(0,5 \mu \mathrm{g} / \mathrm{ml})$ zugesetzt. Die Gellösung wurde in die Gelkammer gegossen, entsprechende Kämme sorgten für Taschenaussparungen zur Befüllung mit DNA-Lösung. Nach Erkalten des Gels wurde der Kamm gezogen und die Gelkammer zur Elektrophorese in einer Pufferkammer arretiert. Die zu elektrophoretisierenden DNA-Proben wurden vor Auftrag mit 1/6 Volumen Sucrosefarbmarker $(6 \mathrm{x})$ versetzt und daraufhin in die Geltaschen gefüllt. Die Elektrophorese fand bei einer konstanten Spannung zwischen $90 \mathrm{~V}$ und $200 \mathrm{~V}$ für 30 bis 60 min statt. Anschließend konnten die aufgetrennten DNA-Fragmente durch Fluoreszenz im UV-Durchlicht bei $302 \mathrm{~nm}$ Wellenlänge sichtbar gemacht und fotografisch dokumentiert werden. Eine Längenbestimmung von DNA-Fragmenten 
wurde durch gleichzeitiges Auftragen von DNA-Markern mit bekannten Fragmentgrößen ermöglicht (2.8).

\subsubsection{Automatische DNA-Sequenzierung am ABI 373 DNA-Sequenzer (Applied Biosystems, Weiterstadt)}

Für die durchgeführten Sequenzierungsexperimente wurde mit dem "Prism Ready Reaction DyeDeoxy Terminator Cycle Sequencing Kit" (Applied Biosystems, Weiterstadt) gearbeitet. Die als Matrize verwendete Plasmid-DNA wurde mit dem Qiagen-Plasmid-Mini-Spin-Kit (3.1.3.2) aufgereinigt.

Das Prinzip dieser Methode basiert auf der Kettenabbruchmethode (SANGER et al. 1977). In einer modifizierten PCR wird ein DNA-Einzelstrang durch Verwendung von fluoreszenzmarkierten Didesoxynukleotiden statistisch nach jeder Base abgebrochen. Die so entstandenen unterschiedlich langen DNA-Einzelstränge werden anschließend in einem Polyacrylamidgel aufgetrennt und passieren größenabhängig unterschiedlich schnell die Detektionseinheit des Sequenzautomaten. Anhand der Art des jeweils eingebauten Didesoxynukleotids ergibt sich die DNA-Sequenz.

Die Sequenzreaktion stellte sich wie folgt zusammen:

$\begin{array}{ll}\text { DNA-Template (Plasmid-DNA) } & 500 \mathrm{ng} \\ \text { Oligonukleotid } & 5 \mathrm{pmol} \\ \text { Terminationsmix } & 6 \mu \mathrm{l} \\ \mathrm{H}_{2} \mathrm{O} \text { bidest } & \text { ad } 17 \mu \mathrm{l}\end{array}$

Die Sequenzreaktion wurde in einem Thermocycler (TC 9600, Perkin Elmer, Norwalk, USA) unter folgenden Bedingungen durchgeführt:

$$
\begin{aligned}
& 20 \sec 94^{\circ} \mathrm{C} \\
& 20 \sec 50{ }^{\circ} \mathrm{C}-60{ }^{\circ} \mathrm{C} \\
& 4 \min 60^{\circ} \mathrm{C}
\end{aligned}
$$

für 25 Zyklen. 
Nach Abschluss der Sequenzreaktion wurden die Proben mit $2 \mu 13$ M Natriumacetat und $50 \mu \mathrm{l}$ Ethanol 15 Minuten bei $-20^{\circ} \mathrm{C}$ gefällt und anschließend 20 Minuten bei $14000 \mathrm{rpm}$ und $4{ }^{\circ} \mathrm{C}$ zentrifugiert. Es folgte ein Waschschritt mit $70 \%$ (v/v) Ethanol. Nach vollständigem Trocknen des DNA-Pellets wurde es in $5 \mu 1$ Formamid/EDTA resuspendiert. Vor dem Auftrag folgte eine Denaturierung der DNA-Einzelstränge für 2 Minuten bei $90{ }^{\circ} \mathrm{C}$ mit anschließender Inkubation der Proben bis zum Auftrag auf Eis.

Die gelelektrophoretische Auftrennung der fluoreszenzmarkierten DNA-Abbruchfragmente erfolgte im ABI 373 Sequenzer über ein $6 \%$ iges Polyacrylamidgel. Das Gel bestand aus $30 \mathrm{~g}$ Harnstoff, $9 \mathrm{ml}$ Acrylamid-Stammlösung (40\% (w/v) AcrylamidBisacrylamid 38:2), $6 \mathrm{ml} 10 \times \mathrm{TBE}$ und 23,5 $\mathrm{ml} \mathrm{H}_{2}$. Die Polymerisation des Gels wurde durch Zugabe von $180 \mu 1 \quad 10 \%$ (w/v) APS und $24 \mu 1$ TEMED gestartet, woraufhin das Gel luftblasenfrei zwischen die beiden Glasplatten gegossen wurde. Nach ca. 1,5 Stunden Polymerisationszeit konnte das Gel in die Pufferkammern des Sequenzautomaten eingespannt werden und nach einer Vorlaufzeit von 20 Minuten mit den denaturierten Sequenzproben beladen werden. Der Sequenzlauf erfolgte meist über Nacht für 10 Stunden.

\subsubsection{DNA-Nachweismethoden}

\subsubsection{Southern-Blot (SOUTHERN, 1975)}

Mit Hilfe des Southern-Blots konnte virale HBV-DNA aus Nukleokapsiden oder Virionen nachgewiesen werden.

Hierzu wurden Nukleokapside aus Zelllysaten bzw. Virionen aus Kulturüberständen immunpräzipitiert (3.1.7.1) und anschließend aufgereinigt (3.1.6.3). Das getrocknete DNA-Pellet wurde in $12 \mu 11 \mathrm{x}$ Probenauftragspuffer wiederaufgenommen und auf einem 1\% TAE-Gel elektrophoretisiert. Als Kontrolle wurden 50-100 pg eines linearen 3,2 kb EcoRV-Fragments des Vektors pRVHBV1.5 mit aufgetragen. Nach der Elektrophorese wurde das Gel zweimal für 15 Minuten in Denaturierungslösung $(0,5 \mathrm{M}$ $\mathrm{NaOH}, 1,5 \mathrm{M} \mathrm{NaCl})$ denaturiert. 


\subsection{DNA-Transfer auf eine Nylonmembran}

Der Blot erfolgte über Nacht mittels Kapillarblot auf eine Biodyne-B-Nylon-Membran, indem ein Flüssigkeitsstrom von Denaturierungspuffer durch das Gel auf die Membran aufgebaut wurde. Nach dem Blot wurde die Membran am nächsten Tag zunächst zweimal 15 Minuten in Neutralisierungspuffer $(0,5 \mathrm{M}$ Tris/ $\mathrm{HCl} \mathrm{pH} 7,5 ; 1,5 \mathrm{M} \mathrm{NaCl})$ neutralisiert und anschließend durch UV-Licht (2,5 Minuten $120 \mathrm{~mJ})$ fixiert.

\subsection{Markierung der Sonde mit alkalischer Phosphatase und Hybridisierung}

Es folgte dann die Hybridisierung der Membran mit einer markierten Sonde. In seltenen Fällen wurde die Membran z. T. auch über mehrere Tage sauber in Vliespapier verpackt bis zur Weiterverarbeitung zwischengelagert.

Für die Hybridisierung wurde das "Alk Phos Direct Kit" (Amersham Pharmacia Biotech, Freiburg) benutzt. Zunächst wurde die Membran in einem Volumen von ca. 12 $\mathrm{ml}$ in $4 \%$ Blockingreagenz, $0,5 \mathrm{M} \mathrm{NaCl}$ bei $60{ }^{\circ} \mathrm{C}$ in einem Hybridisierungsröhrchen im Hybridisierungsofen für 30 Minuten präinkubiert. Währenddessen wurde die Sonde mit alkalischer Phosphatase markiert. Als Sonde kam ebenfalls das 3,2 kb EcoRVFragment des Vektors pRVHBV1.5 zum Einsatz. 100 ng DNA wurden hierfür zunächst in $10 \mu \mathrm{l}$ Volumen für 5 Minuten bei $100{ }^{\circ} \mathrm{C}$ denaturiert und anschließend für 5 Minuten auf Eis abgekühlt. Die DNA wurde dann mit den folgenden Bestandteilen aus dem Kit versetzt: $10 \mu \mathrm{l}$ Reaktionspuffer, $2 \mu \mathrm{l}$ Labeling Reagenz und $10 \mu 1$ Crosslinker (1:5 verdünnt). Die Inkubationsbedingung für die Markierung betrug $37^{\circ} \mathrm{C}$ für 30 Minuten. Nach Vollendung der Markierungsreaktion wurde der Ansatz zum Hybridisierungsansatz hinzupipettiert und über Nacht bei $60^{\circ} \mathrm{C}$ im Hybridisierungsofen weiter inkubiert.

\subsection{Nachweis der Sonde}

Nach der Hybridisierung der Sonde auf der Membran folgten am nächsten Tag zwei Waschschritte und die Detektion. Es wurde zunächst zweimal 10 Minuten mit dem auf $60{ }^{\circ} \mathrm{C}$ vorgewärmten Waschpuffer 1 (2 M Harnstoff; 0,1 \% SDS; 50 mM Na-P, pH 7,0; 
$150 \mathrm{mM} \mathrm{NaCl} ; 10 \mathrm{mM} \mathrm{MgCl} 2 ; 0,2 \%$ Blocking Reagenz) gewaschen. Nach dem zweiten Waschschritt wurde die Membran aus dem Hybridisierungsröhrchen in eine Waschschale transferiert. Es folgten Waschschritte über zweimal 5 Minuten in Waschpuffer 2 (50 mM Tris, $\mathrm{pH} 10 ; 100 \mathrm{mM} \mathrm{NaCl} ; 2 \mathrm{mM} \mathrm{MgCl}$ ) bei Raumtemperatur unter leichtem Schütteln.

Zur Detektion der mit alkalischer Phosphatase gekoppelten Sonde auf der Membran wurde das CDP-Star-Kit (Amersham Pharmacia Biotech, Freiburg) eingesetzt. Es wurden $30-40 \mu 1 / \mathrm{cm}^{2}$ des Reagenz mit der zuvor getrockneten Membran für 3 bis 5 Minuten inkubiert. Nach Abtropfen der Membran wurde sie in einen Hybridisierungsbeutel eingeschweißt. Die Chemilumineszenz der Reaktion wurde auf einem Röntgenfilm (Biomax MR, Kodak, New Haven, USA) für 30 Minuten bis 2 Tage detektiert.

\subsubsection{Nachweis von HBV-ccc-DNA mittels endogener Polymerase-Reaktion}

Die endogene Polymerase-Reaktion erlaubt es, spezifisch HBV-ccc-DNA von Nukleokapsiden aus Zelllysaten und Virionen aus Zellkulturüberständen nachzuweisen. Bietet man Nukleokapsiden oder Virionen unter Gabe von Detergenz radioaktiv markierte Nukleotide an, so werden diese durch die endogene virale Polymerase in das partiell doppelsträngige DNA-Genom eingebaut, wodurch es gleichzeitig zur Markierung kommt.

Für den endogenen Polymerase-Nachweis wurden Nukleokapside aus Zelllysaten und Virionen aus Zellkulturüberständen HBV-transfizierter HuH7-Zellen immunpräzipitiert (3.1.7.1) und mit einer ausgezogenen Pasteurpipette restlos vom PBS befreit. Zur Markierung des Genoms diente radioaktiv markiertes $\alpha^{32} \mathrm{P}-\mathrm{dCTP}$, welches in äquimolarer Menge zu den anderen Nukleotiden dGTP, dATP und dTTP dem Reaktionsansatz zugegeben wurde. Pro Ansatz wurden folgende Bestandteile pipettiert:

$$
\begin{array}{lr}
2 \mathrm{x} \text { inc. Pol. Puffer } & 25 \mu \mathrm{l} \\
1 \mathrm{M} \mathrm{MgCl}_{2} & 1 \mu \mathrm{l} \\
10 \% ß \text {-Mercapto-Ethanol } & 0,5 \mu \mathrm{l} \\
10 \%(\mathrm{v} / \mathrm{v}) \mathrm{NP}_{40} & 2,5 \mu \mathrm{l}
\end{array}
$$




$\begin{array}{lr}30 \mathrm{mM} \text { dGAT } & 2 \mu \mathrm{l} \\ \alpha^{32} \text { PdCTP }(10 \mu \mathrm{Ci}) & 1 \mu \mathrm{l} \\ \mathrm{H}_{2} \mathrm{O} & 18 \mu \mathrm{l}\end{array}$

Die Inkubation fand über Nacht bei $37^{\circ} \mathrm{C}$ im Brutschrank des Isotopenlabors statt. Am nächsten Tag wurden die Proben aufgereinigt (3.1.6.3), bevor sie auf einem Agarosegel aufgetrennt, getrocknet und autoradiographiert wurden.

Nach der Aufreinigung der Nukleokapside und Virionen (3.1.6.3) erfolgte eine $1 \%$ Agarosegelelektrophorese (3.1.4.6) in TBE-Puffer. Die getrockneten DNA-Proben wurden hierfür zunächst in $12 \mu 11 \mathrm{x}$ Probenpuffer wieder aufgenommen und anschließend auf ein TBE-Gel aufgetragen, welches kein Etidiumbromid enthielt. Nach der Elektrophorese wurde das Gel auf ein Whatmann-Vliespapier gelegt und im Geltrockner (Biotec Fischer, Reiskirchen) unter Vakuum und Hitze getrocknet, bevor die Signale auf einem Kodak-Screen (Biorad, München, 3.1.8) aufgezeichnet und mittels Phosphoimager (Biorad, München, 3.1.8) analysiert wurden.

\subsubsection{Aufreinigung von Nukleokapsiden und Virionen zur viralen DNA-Isolierung}

Die Aufreinigung von Nukleokapsiden und Virionen erfolgte meistens nach Immunpräzipitation mit entsprechenden Antikörpern wie anti-HBc bzw. anti-HBs. Das Ausgangsvolumen betrug $50 \mu \mathrm{l}$ aus einem EPR-Ansatz (3.1.6.2) oder wurde auf $50 \mu 1$ mit PBS aufgefüllt. Die ersten Schritte der Aufreinigung umfassten zwei enzymatische Verdaue mit DNAseI und Proteinase-K. Der DNAseI-Verdau diente dazu, unspezifische extrakapsidale DNA zu degradieren. Es wurden hierfür pro Ansatz folgende Komponenten vorgemischt und anschließend als Totalvolumen von $20 \mu \mathrm{zu}$ den Proben pipettiert:

$$
\begin{array}{lr}
\text { DNAse I }(10 \mathrm{mg} / \mathrm{ml}) & 0,5 \mu \mathrm{l} \\
2 \mathrm{x} \text { inc. pol. Puffer } & 10 \mu \mathrm{l} \\
\mathrm{H}_{2} \mathrm{O} & 9,5 \mu \mathrm{l}
\end{array}
$$

Die Inkubation des DNAseI-Verdaus betrug 30 Minuten bei Raumtemperatur.

Ein anschließender Proteinase-K-Verdau sorgte für ein enzymatisches Aufspalten der Nukleokapside, um nachfolgend die virale DNA isolieren zu können. Es wurden hierfür 
pro Ansatz folgende Komponenten vorgemischt und als Totalvolumen von $70 \mu \mathrm{zu}$ den Ansätzen pipettiert:

$$
\begin{array}{lr}
2 \text { x Proteinase-K-Puffer } & 65,1 \mu l \\
\text { Proteinase-K }(10 \mathrm{mg} / \mathrm{ml}) & 4,2 \mu 1 \\
\text { tRNA }(10 \mathrm{mg} / \mathrm{ml}) & 0,7 \mu \mathrm{l}
\end{array}
$$

Die Inkubation des Proteinase-K-Verdaus betrug 30 Minuten bei Raumtemperatur.

Zur Aufreinigung wurden nachfolgend die Proben zunächst einmal mit Phenol/Chloroform extrahiert. Hierfür wurde das Probenvolumen an Phenol/Chloroform zu den Proben gegeben, 15 Sekunden durchmischt und abzentrifugiert. Die Überstände wurden in neue Eppendorf-Reaktionsgefäße überführt und zweimal mit Ethanol/Acetat gefällt. Die erste Ethanol/Acetatfällung erfolgte nach Zugabe von $35 \mu 110 \mathrm{M} \mathrm{NH}_{4} \mathrm{Ac}$ und 350 $\mu 1$ Ethanol für 15 Minuten bei Raumtemperatur. Die Proben wurden anschließend für 15 Minuten abzentrifugiert, die Überstände verworfen und das DNA-Pellet in $100 \mu 1$ TE-Puffer resuspendiert. Die zweite Ethanol/Acetatfällung erfolgte nach Zugabe von $25 \mu 110 \mathrm{M} \mathrm{NH}_{4} \mathrm{Ac}$ und $250 \mu \mathrm{l}$ Ethanol für ebenfalls 15 Minuten bei Raumtemperatur. Die Proben wurden anschließend für 15 Minuten abzentrifugiert, der Überstand verworfen und das DNA-Pellet im Heizblock bei $37^{\circ} \mathrm{C}$ getrocknet.

\subsubsection{HBV-Nachweis mittels PCR}

Der HBV-Nachweis mittels PCR ermöglichte es, eine Aussage über eine erfolgreiche Bindung von HBV-Virionen an MA18/7 transfizierte Zellen zu treffen. Hierzu wurde die aufgereinigte DNA aus Virionbindungs- (3.3.8.1) und Virionaufnahmeassays (3.3.8.2) in Verdünnungsstufen $10^{-2}, 10^{-3}, 10^{-4}$ und $10^{-5}$ verdünnt und als Template für eine PCR-Reaktion verwendet. Hierbei wurde in einer ersten Touchdown-PCR aus einem Gesamtpool von DNA das spezifisch zu amplifizierende HBV-DNA-Produkt amplifiziert, indem die Primeranlagerungstemperatur an ihre spezifische Temperatur herangeführt wurde. Ein zweites, nachfolgendes Programm diente zur spezifischen Amplifikation des zu erzielenden HBV-Genomfragments. Es herrschten Standard-PCR-

Bedingungen unter Verwendung der Primerpaare \#0152 und \#0285 sowie einer Substitution von $4 \mathrm{mM} \mathrm{MgCl}_{2}$. 
Das PCR-Programm wurde wie folgt gewählt:

$\begin{array}{lll}14 \text { Zyklen } & 30 \mathrm{sek} & 96^{\circ} \mathrm{C} \\ \text { (“touch down”) } & 15 \mathrm{sek} & 60-53^{\circ} \mathrm{C}\left(-0,5^{\circ} \mathrm{C} / \text { Zyklus }\right) \\ & 45 \mathrm{sek} & 72^{\circ} \mathrm{C} \\ & & \\ 15 \text { Zyklen } & 30 \mathrm{sek} & 96^{\circ} \mathrm{C} \\ & 15 \mathrm{sek} & 53^{\circ} \mathrm{C} \\ & 45 \mathrm{sek} & 72^{\circ} \mathrm{C} \\ & & 72^{\circ} \mathrm{C}\end{array}$

\subsubsection{Direkte Klonierung von PCR-Produkten mit dem TA-Cloning-Kit (Invitrogen)}

PCR-Produkte, die mit Taq-Polymerase amplifiziert wurden, konnten direkt für eine Ligation in das linear vorliegende Plasmid pCR2.1 eingesetzt werden.

Taq-Polymerase finalisiert bei der Amplifikation von DNA-Molekülen am 3'-Ende die Elongation mit dem Anhängen einer zusätzlichen Adeninbase. Das heisst, beide Enden eines Amplifikats besitzen am 3'-Ende eine Adeninbase, welche für eine spezifische Ligation verwendet werden kann. Diese Eigenschaft macht sich das TA-Cloning-Kit zunutze, indem es für eine Ligation einen Vektor anbietet, der jeweils 5'-überhängende komplementäre Tyminbasen enthält (pCR2.1, 2.5).

Die Ligation erfolgte nach Herstellerprotokoll. Anschließend wurden die Ligationsansätze in E. coli DH5 $\alpha$ transformiert. 


\subsubsection{Arbeiten mit Proteinen}

\subsubsection{Immunpräzipitation}

Nukleokapside aus Zelllysaten und Virionen aus Zellkulturüberständen HBVtransfizierter Zellkulturen konnten mittels spezifischer Antikörper an Protein-ASepharosebeats spezifisch gebunden und präzipitiert werden.

Hierfür wurde einen Tag vor Ernte der Zellkultur pro 10-cm-Schale 2,5 mg Protein-ASepharosebeats eingewogen und in PBS gequollen. Nach dreimaligem Waschen der Beats mit PBS wurden diese in 50-70 $\mu$ PBS pro Ansatz wiederaufgenommen, mit $1 \mu 1$ Antikörper versetzt und über Nacht bei $4{ }^{\circ} \mathrm{C}$ auf dem Probenroller präinkubiert. Zur Immunpräzipitation von Nukleokapsiden wurde ein polyklonaler Kaninchen-anti-HBcAntikörper (2.7), zur Immunpräzipitation von Virionen ein polyklonaler Ziege-antiHBs-Antikörper (2.7) verwendet.

Nach Ernte der Zellen wurden sowohl die Zellkulturüberstände als auch die Zelllysate vor der Immunpräzipitation abzentrifugiert (10 Minuten bei $14000 \mathrm{rpm}$ und RT) um unspezifische Proteine zu pelletieren. Die Präinkubation der Protein-A-Sepharosebeats wurde einmal mit PBS gewaschen und zu ca. $1 \mathrm{ml}$ Zelllysat bzw. Zellkulturüberstand hinzupipettiert. Die Inkubation der Immunpräzipitation erfolgte über Nacht bei $4{ }^{\circ} \mathrm{C}$ auf dem Probenroller. Vor Weiterverwendung der Immunpräzipitate am nächsten Tag wurden diese zuvor einmal mit PBS gewaschen, um unspezifisch gebundene Proteine zu entfernen.

\subsubsection{SDS-Polyacrylamid-Gelelektrophorese}

Die Auftrennung von Proteinen erfolgte in vertikalen Gelkammern unter denaturierenden Bedingungen. Es wurde überwiegend das Studier-ElektrophoreseKammersystem (STUDIER, 1973) mit einer Lauflänge von ca. $20 \mathrm{~cm}$ im Trenngel und ca. $5 \mathrm{~cm}$ im Sammelgel verwendet.

Die Gele wurden jeweils zwischen zwei Glasplatten der Größe 18 x 27 cm gegossen. Die Vorderplatte trug eine Aussparung, in der später der Kamm eingeschoben wurde, der die Geltaschen produzierte. Die Spacer zwischen den Glasplatten, die die Dicke des 
Gels festlegten, wurden mit einer Schicht Vaseline abgedichtet. Die denaturierten Proteine wurden im diskontinuierlichen Polyacrylamid unter reduzierenden Bedingungen analysiert (LAEMMLI, 1970). Es wurden hierzu die Proteine zunächst in einem 5\%igen Sammelgel konzentriert und anschließend in einem 13 - 15 \%igen Polyacrylamidgel ihrer Größe entsprechend aufgetrennt. Nach dem Zusammenbau der Gelform wurde dementsprechend zunächst das Trenngel pipettiert und bis ca. $5 \mathrm{~cm}$ unter den Glasplattenrand gegossen. Zur Sicherstellung einer blasenfreien geraden Gellinie wurde das Gel mit $20 \%$ Methanol überschichtet und für ca. 30 Minuten auspolymerisieren lassen. Nach vollständiger Polymerisisation des Trenngels konnte das Methanol abgegossen und das Sammelgel eingefüllt werden. Anschließend wurde der Kamm eingesetzt und das Sammelgel erneut für 30 Minuten polymerisieren lassen.

Für die verschiedenen Gele wurden folgende Bestandteile pipettiert:

\begin{tabular}{|c|c|c|c|c|}
\hline & $5 \%$ Sammelgel & $13 \%$ & Trenngel & $15 \%$ \\
\hline $\mathrm{H}_{2} \mathrm{O}$ & $7,4 \mathrm{ml}$ & $12,0 \mathrm{ml}$ & & $10,5 \mathrm{ml}$ \\
\hline 4 x Puffer & $3,0 \mathrm{ml}$ & $7,5 \mathrm{ml}$ & & $7,5 \mathrm{ml}$ \\
\hline Acrylamid & $1,6 \mathrm{ml}$ & $10,3 \mathrm{ml}$ & & $11,8 \mathrm{ml}$ \\
\hline Temed & $20 \mu l$ & $50 \mu 1$ & & $50 \mu 1$ \\
\hline APS & $80 \mu 1$ & $200 \mu 1$ & & $200 \mu 1$ \\
\hline
\end{tabular}

Als Puffer wurde entsprechend Trenngelpuffer oder Sammelgelpuffer eingesetzt. Die Acrylamid-Stammlösung bestand aus $39 \%$ (w/v) Acrylamid und $1 \%$ bis-Acrylamid.

Nach Polymerisation des Gels wurde der untere Spacer entfernt und das Gel an der Stelle mit SDS-Lösung von der Vaseline gereinigt. Anschließend wurde das Gel in die Elektrophoresekammer eingespannt und mit Laufpuffer versorgt.

Die aufzutrennende Proteinlösung wurde dann mit gleichem Volumen 2 x Probenauftragspuffer und $10 \%$ (w/v) DTT vermischt und zur Spaltung der Disulfidbrücken für 5 Minuten bei $95^{\circ} \mathrm{C}$ aufgekocht. Nach Befüllen der Taschen wurde das Gel über Nacht bei $5 \mathrm{~mA}$ oder für 4 Stunden bei $30 \mathrm{~mA}$ elektrophoretisiert. 
Zur Darstellung der aufgetrennten Proteine konnte das Gel anschließend mit Comassie gefärbt und wieder entfärbt werden (3.1.8.3). Die Darstellung radioaktiv markierter Proteine beispielsweise nach Puls-Chaise-Experimenten (3.3.9) erfolgte nach Trocknen des Gels auf dem Geltrockner (Biotec Fischer, Reiskirchen) unter Vakuum und Hitze und Auflegen eines Kodak K-Screens (Biorad, München) sowie nachfolgender Analyse der Signale mittels Phosphoimager (Biorad, München 3.1.9).

\subsubsection{Comassiefärbung von Polyacrylamidgelen}

Die in einem Polyacrylamidgel separierten Proteine konnten mittels Comassie-BrillantBlau angefärbt werden. Hierbei wurden im Färbeschritt zunächst das gesamte Gel angefärbt und in den nachfolgenden Entfärbeschritten die Bereiche des Gels wieder entfärbt, die kein Protein enthielten.

Hierfür wurde das Polyacrylamidgel für 30 Minuten in Comassie-Färbelösung unter leichtem Schwenken inkubiert. Die Visualisierung spezifischer Proteinbanden erfolgte nach Entfärben. Das Entfärben geschah entweder durch Inkubation für 45 Minuten in Comassie-Entfärbelösung oder durch mehrmaliges Aufkochen des Gels in $\mathrm{H}_{2} \mathrm{O}$ mittels Mikrowellenofen. Das entfärbte Gel konnte nachfolgend im Geltrockner (Biotec Fischer, Reiskirchen) unter Vakuum und Hitze getrocknet werden.

\subsubsection{PEG-Fällung von HBV-Kapsiden}

Eine einfache Methode zur Einkonzentrierung von HBV-Kapsiden beruht auf der Fällung des Proteins durch PEG 8000.

Eine HBV-transfizierte Zellkultur $\mathrm{HuH7}$ wurde lysiert (3.3.6) und abzentrifugiert. $800 \mu \mathrm{l}$ des klaren Überstands wurden mit $10 \%$ (w/v) festem PEG 8000 und $2 \%$ (w/v) $\mathrm{NaCl}$ versetzt und über Nacht bei $4{ }^{\circ} \mathrm{C}$ auf dem Überkopfroller (Snijders, Tilburg, NL) inkubiert. Es folgte am nächsten Tag zunächst ein Zentrifugationsschritt für 60 Minuten bei $4000 \mathrm{rpm}$ und $4{ }^{\circ} \mathrm{C}$ in der Kühlzentrifuge. Der Überstand wurde verworfen und das Pellet in $25 \mu 1$ TNE-Puffer mittels Thermoheizblock (Eppendorf, Hamburg) bei 1400 rpm 15 Minuten resuspendiert. Das Resuspensat wurde schließlich für 15 Minuten bei 
$4000 \mathrm{rpm}$ und $4{ }^{\circ} \mathrm{C}$ in der Kühlzentrifuge kurz anzentrifugiert. Der kapsidenthaltende Überstand wurde dann bis zur nativen Agarosegelelektrophorese und Western-Blot bei $4{ }^{\circ} \mathrm{C}$ im Kühlschrank oder auf Eis gelagert.

\subsubsection{Western-Blot von Coreprotein unter nativen Bedingungen (Burette, 1981)}

Beim Western-Blot kommt es zur Immobilisierung eines im Gel separierten Proteins durch Transfer auf eine Trägermembran. Der Nachweis des Zielproteins erfolgt anschließend im Immunoblot (3.1.7.8) mit einem spezifischen ersten Antikörper und durch einen konjugierten zweiten Antikörper, der in einer Indikatorfarbreaktion nachgewiesen werden kann.

Der Western-Blot von Coreproteinen wurde unter nativen Bedingungen durchgeführt, so dass anhand des Laufverhaltens im nativen Agarosegel angeschätzt werden konnte, inwiefern getestete Coremutanten noch in der Lage gewesen waren, vollständig zu Kapsiden zu assemblieren.

Die aus der PEG-Fällung (3.1.7.6) einkonzentrierten Kapside eines Zelllysats (3.3.6) einer transfizierten HuH7-Zellkultur (3.3.3) wurden auf ein $1 \%$ Agarosegel mit großem Geltaschenvolumen in TAE-Puffer aufgetragen. Der Auftrag erfolgte in 1/5 Volumen Probenauftragspuffer, der kein EDTA enthalten durfte. Nach der Agarosegelelektrophorese wurden die separierten Proteine des Gels mittels Kapillarblot auf eine Nitrozellulosemembran $(0,2 \mu \mathrm{m}$, Schleicher und Schuell, Dassel) transferiert, indem ein Flüssigkeitsstrom von $10 \mathrm{x}$ SSC Puffersystem durch das Gel auf die Membran aufgebaut wurde. Der Kapillarblot erfolgte über Nacht bei Raumtemperatur.

\subsubsection{Immunblot}

Für den Nachweis des durch den Western-Blot (3.1.7.7) auf die Nitrozellulosemembran transferierten Antigens wurde die Membran zunächst für eine Stunde mit $10 \%$ (w/v) Sucofin in 0,1\% (v/v) Tween 20/PBS bei Raumtemperatur zum Blocken unspezifischer Bindungen auf dem Schüttler inkubiert. Es folgte ein dreimaliger Waschschritt für 15 Minuten mit 0,1\%(v/v) Tween 20/PBS bei Raum-temperatur auf dem Schüttler. Als 
erster Antikörper diente ein anti-HBc-polyklonales Serum aus dem Kaninchen, welches anschließend in einer 1:2000 Verdünnung in 10\% (w/v) Sucofin 0,1\%(v/v) Tween 20/PBS für zwei Stunden bei Raumtemperatur oder über Nacht bei $4{ }^{\circ} \mathrm{C}$ inkubiert wurde. Vor Inkubation des zweiten Antikörperkonjugats wurde die Membran wiederum dreimal mit 0,1\%(v/v) Tween 20/PBS gewaschen. Als zweiter Antikörper diente ein anti-Kaninchen IgG Peroxydase-Konjugat, der in einer Verdünnung von 1:500 000 in $10 \%(w / v)$ Sucofin 0,1\% (v/v) Tween 20/PBS für 90 Minuten auf dem Schüttler inkubiert wurde. Es folgten wiederum drei Waschschritte mit $0,1 \%(\mathrm{v} / \mathrm{v})$ Tween 20/PBS und zwei Waschschritte mit PBS.

Die Detektion des peroxydasekonjugierten Antikörpers erfolgte über das Chemilumineszenzsystem ECL (Amersham Pharmacia Biotech, Freiburg). Jeweils $2 \mathrm{ml}$ der Lösungen „Super-Signal West Pico Luminol/Enhancer“ und „Super-Signal West Pico Stable Peroxide“" wurden vorgemischt und für fünf Minuten auf die Membran gegeben. Nach der Inkubation wurde die Membran in einen Hybridisierungsbeutel eingeschweißt und auf einen Röntgenfilm (Biomax MR, Kodak, New Haven, USA) für eine Minute bis eine Stunde inkubiert.

\subsubsection{Autoradiographie}

Alternativ zur Exponierung auf einem Röntgenfilm (Biomax MR, Kodak, New Haven, USA) wurden radioaktiv markierte Proben nach Anschaffung des Phosphoimagers (Molecular Imager FX, Biorad München) für drei Stunden bis einen Tag auf einem K-Screen (Biorad, München) exponiert und konnten nachfolgend mittels Quantity One Software quantitativ ausgewertet werden. 


\subsubsection{Isolierung von mRNA mittels Oligotex-direct-mRNA-Kit (Qiagen)}

Die Isolierung von mRNA basiert bei dieser Methode auf einem an eine Matrix gebundenen Oligo-T-Nukleotid, das in der Lage ist, aus eukaryontischen Zelllysaten polyadenylierte mRNAs zu binden. Anschließend kann die Matrix abzentrifugiert und durch Waschschritte aufgereinigt werden.

Die Durchführung erfolgte nach Herstellerprotokoll.

\subsubsection{1 cDNA-Synthese und PCR-Amplifikation mit dem ONE-STEP-RT-PCR-Kit (Gibco BRL, Eggenstein)}

cDNA-Synthese und PCR erfolgten hierbei in einem Ansatz. In einem ersten Schritt werden durch ein unspezifisches Oligo-dT-Oligonukleotid (\#0162) alle isolierten mRNAs in cDNA umgeschrieben. Die spezifische Amplifikation des gesuchten Gens erfolgt in der nachfolgenden PCR durch spezifische Oligonukleotide.

Die Durchführung erfolgte nach Herstellerangaben.

\subsection{Mikrobiologische Methoden}

\subsubsection{Arbeiten und Umgang mit Bakterien}

\subsubsection{Stammhaltung}

Die Lagerung der verwendeten Escherichia coli-Bakterienstämme (E. coli) erfolgte zur längerfristigen Aufbewahrung als Glycerinkulturen bei $-22^{\circ} \mathrm{C}$. Hierfür wurde $1 \mathrm{ml}$ Übernachtkultur mit $2 \mathrm{ml}$ autoklaviertem Glycerin vermischt. Bakterienstämme, die häufiger verwendet wurden, konnten auf LB-Vollmediumplatten mehrere Wochen bei $4{ }^{\circ} \mathrm{C}$ im Kühlschrank gelagert werden. 


\subsubsection{Vermehrung von E. coli-Bakterien}

Alle E. coli-Kulturen wurden, soweit nicht anders vermerkt, bei $37^{\circ} \mathrm{C}$ unter Gewährleistung von ausreichender Belüftung angezogen. Als Medien dienten sowohl LB-Vollmedium als auch TB-Vollmedium oder dYT-Vollmedium. Im Falle von plasmidkodierter Resistenz wurden die Medien mit entsprechenden Antibiotika, meist Ampicillin in der Endkonzentration von $100 \mu \mathrm{g} / \mathrm{ml}$ komplettiert. Als Anzuchtgefäße dienten für Kulturen unter $5 \mathrm{ml}$ Glasröhrchen, die durch Rollen oder Schütteln inkubiert wurden. Kulturvolumina von $20 \mathrm{ml}$ bis $50 \mathrm{ml}$ wurden in Erlenmeyerkolben durch Schütteln bei $150 \mathrm{rpm}$ inkubiert. Das Beimpfen der Medien erfolgte durch Einzelkolonien oder Plattenabstrichen aus Glycerin- oder Mediumkulturen.

\subsubsection{Bestimmung der Zelldichte}

Die Zelldichte der Kulturen wurde durch Vermessen der optischen Dichte bei $600 \mathrm{~nm}$ Wellenlänge am Photometer (Beckmann DU70 Spektralphotometer) bestimmt. Die Kultur wurde vorher bis $\mathrm{zu}$ einer maximalen Zelldichte von $\mathrm{OD}_{600}=1 \mathrm{mit}$ Flüssigmedium verdünnt.

\subsubsection{Herstellung kompetenter $E$. coli-Bakterien}

Transformationen von Plasmid-DNA sowie ligierter Plasmid-DNA nach Klonierungen wurden durch Hitzeschocktransformation durchgeführt. Hierfür mussten die E. coliZellen in einen besonderen kompetenten Zustand versetzt werden, der ihnen eine effektive Aufnahme von DNA ermöglichte (nach HANAHAN et al., 1983).

Aus einer Übernachtkultur E. coli wurden $100 \mathrm{ml}$ TYM-Medium angeimpft und bei $37^{\circ} \mathrm{C}$ und $110 \mathrm{rpm}$ auf dem Schüttler (Lab-Shaker, Braun, Melsungen) inkubiert. Nach wenigen Stunden erreichte die Kultur eine optische Dichte $\mathrm{OD}_{600}$ von 0,4 und konnte geerntet werden. Die Kultur wurde kurz auf Eis runtergekühlt und es folgte eine Zentrifugation in zwei $50 \mathrm{ml}$ Sarstedt-Röhrchen für 5 Minuten bei $3000 \mathrm{rpm}$ und $4{ }^{\circ} \mathrm{C}$. Der Überstand wurde verworfen, die Wiederaufnahme des Zellpellets erfolgte in $40 \mathrm{ml}$ sterilem eiskalten Transformationspuffer I, woraufhin sich eine Inkubationszeit von 
40 Minuten auf Eis anschloss. Nach erneuter Zentrifugation der Bakterienkultur unter gleichen Bedingungen wurde das Zellpellet in $4 \mathrm{ml}$ sterilen eiskalten Transformationspuffer II resuspendiert. Die Zellen konnten nun in vorgekühlte 1,5 ml EppendorfReaktionsgefäße portioniert und in flüssigem Stickstoff schockgefroren werden, bevor sie bei $-70{ }^{\circ} \mathrm{C}$ bis zur Transformation aufbewahrt wurden.

\subsubsection{Transformation von $E$. coli-Bakterien durch Hitzeschock}

Für eine Transformation von E. coli wurden pro Ansatz 35 bis $70 \mu 1$ Zellen langsam auf Eis aufgetaut. Die Menge transformierter DNA variierte bei Plasmid-DNA zwischen $10 \mathrm{pg}$ und $1 \mathrm{ng}$ und bei Ligationen zwischen $5 \mu \mathrm{l}$ und $20 \mu \mathrm{l}$ Ansätzen. Vor dem Hitzeschock wurde die DNA zu den Zellen hinzupipettiert und für ca. 30 Minuten präinkubiert. Der nachfolgende Hitzeschock erstreckte sich über 90 Sekunden bei $42{ }^{\circ} \mathrm{C}$, wobei unmittelbar danach die Zellen wiederum 2 Minuten auf Eis inkubiert wurden, bevor sie mit $200 \mu \mathrm{l}$ Medium versehen und 45 Minuten bei $37^{\circ} \mathrm{C}$ inkubiert wurden. Anschließend konnte eine Verdünnungsreihe von $200 \mu 1,20 \mu 1$ und $2 \mu 1$ auf LB-Amp-Platten ausplattiert werden.

\subsubsection{Vereinzelung von $E$. coli-Bakterien}

Die Vereinzelung einer Kultur von E. coli gestaltete sich nach der Dreistrich-Methode. Aus einer hochgewachsenen Flüssigkultur wurde ein steriler Glasstab benetzt und mit drei Strichen eine Agarplatte beimpft. Ein zweiter steriler Glasstab führte drei weitere Striche auf der Agarplatte durch, die die ersten Striche kreuzten. Nach einer dritten Prozedur sollten nach Anwachsen der Kultur über Nacht bei $37{ }^{\circ} \mathrm{C}$ im Brutschrank im Bereich der dritten Strichführungen Einzelkolonien angewachsen sein. 


\subsection{Arbeiten mit Zellkulturen}

\subsubsection{Kultivierung von Säugerzellen}

Die Kultivierung der adhärenten Zellkulturen HuH7, HepG2 und COS7 erfolgte im Brutschrank (Hera Cell 240) bei $37^{\circ} \mathrm{C}, 5 \% \mathrm{CO}_{2}$ und wasserdampfgesättigter Atmosphäre in 10-cm-Schalen (Corning Costar, USA) oder zu Versuchen in $2 \mathrm{~cm}$ 6-well-Schalen. Die Nährmedien wurden in Kapitel 2.3.2 aufgezählt.

Alle zwei bis drei Tage nach vollständigem Hochwachsen der Zellkulturen wurden sie gesplittet. Hierzu wurde das Medium einer Schale verworfen und die Zellen mit $10 \mathrm{ml}$ auf $37^{\circ} \mathrm{C}$ vorgewärmten PBS gewaschen. Zum Ablösen wurden die Zellen anschließend mit Trypsin/EDTA (Biochrom, Berlin) bei $37^{\circ} \mathrm{C}$ inkubiert und danach in frischem, vorgewärmten Medium rekultiviert. Das Umsetzungs-verhältnis bei HuH7und COS7-Zellen variierte je nach Zelldichte zwischen 1:6 bis 1:8 und bei HepG2Zellen bei 1:2 bis 1:3.

\subsubsection{Transfektion von HuH7- und HepG2- Zellen mit Calciumphosphatpräzipitaten}

Ähnlich wie Bakterienzellen sind auch Säugetierzellen unter bestimmten Bedingungen in der Lage, DNA aufzunehmen. HuH7- und HepG2-Zellen tun dies vor allem durch Koaufnahme mit Calciumphosphatpräzipitaten oder aber auch als Einschlusskörper in lipidhaltigen Micellen, wie sie als Kit verschiedener Hersteller angeboten werden.

Einen Tag vor der Transfektion wurden die Zellen entweder in 10-cm-Schalen oder in $2 \mathrm{~cm}$ 6-well-Schalen in einem Verhältnis gesplittet, dass die Zellen am Tag der Transfektion mindestens $60 \%$ konfluent gewachsen waren. Die Calciumphosphatpräzipitate für eine 10-cm-Schale wurden folgendermaßen hergestellt: $10 \mu \mathrm{g}$ Plasmid-

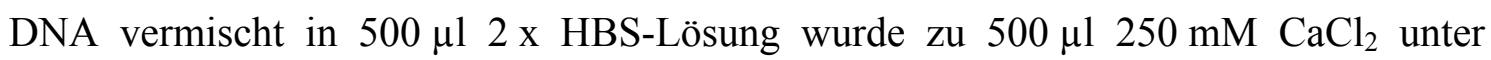
leichtem Rühren hinzugetropft. Für kleinere Kulturschalen wurde entsprechend weniger genommen ( $2 \mathrm{~cm}$ 6-well: $2 \mu \mathrm{g}$ Plasmid in $200 \mu \mathrm{l} ; 5$-cm-Schale: $5 \mu \mathrm{g}$ Plasmid in $500 \mu \mathrm{l}$ Transfektionslösung). Die Präzipitate bildeten sich innerhalb der nächsten 30 Minuten 
aus und wurden anschließend auf das Zellkulturmedium getropft. Nach acht Stunden Inkubation wurde das präzipitathaltige Medium entfernt, die Zellen mit PBS gewaschen und mit frischem Medium versetzt.

\subsubsection{Transfektion von COS7-Zellen mit DEAE-Dextran/Chloroquine}

COS7-Zellen ließen sich durch DEAE-Dextran/Chloroquine transfizieren. Die Zellen wurden in gleicher Weise einen Tag zuvor vorbereitet und waren am Tag der Transfektion mindestens $60 \%$ konfluent gewachsen. Die Transfektion einer 10-cm-Schale erfolgte durch hinzupipettieren von $10 \mu \mathrm{g}$ Plasmid-DNA und $40 \mu \mathrm{l}$ DEAE-Dextran/Chloroquine. Nach 3-4 Stunden wurde das Transfektionsmedium entfernt und die Zellen eine Minute in $1 \mathrm{ml} 10 \%$ (v/v) DMSO in PBS inkubiert. Nach Waschen mit PBS wurden die Zellen mit frischem Medium versetzt.

\subsubsection{Einfrieren und Auftauen von Säugerzellen}

Zur längeren Lagerung von Zellkulturen wurden diese in flüssigem Stickstoff aufbewahrt. Hierzu wurden 1 x $10^{6}$ Zellen in Medium resuspendiert, welches $10 \%$ (v/v) DMSO enthielt und in Einfrierröhrchen aliquotiert. Die Röhrchen wurden daraufhin schrittweise erst auf Eis, dann zwei Stunden bei $-20^{\circ} \mathrm{C}$ und über Nacht bei $-70{ }^{\circ} \mathrm{C}$ runtergekühlt, bevor sie in katalogisierter Position in den Stickstofftank überführt wurden.

Zur Inkulturnahme wurden die Zellen auf Eis aufgetaut und langsam mit $10 \mathrm{ml}$ vorgewärmtem Medium ausverdünnt. Einmaliges Abzentrifugieren der Zellen für 2 Minuten bei $1000 \mathrm{rpm}$ entfernte das restliche DMSO und tote Zellbestandteile. Nach Wiederaufnahme des Zellpellets mit $12 \mathrm{ml}$ Medium wurde das gesamte Volumen in eine 10-cm-Schale ausgesät und unter oben beschriebenen Zellkulturbedingungen inkubiert. 


\subsubsection{Bestimmung von HBsAg und HBeAg}

Als sichere Einschätzung der Transfektionseffizienz nach Transfektion HBV-DNAtragender Plasmide konnte in den meisten Fällen eine HBsAg bzw. HBeAgBestimmung durchgeführt werden, sofern diese Antigene plasmidvermittelt wurden. Der Test wurde freundlicherweise von der Hepatitis-Diagnostik im Haus durchgeführt. (HBsAg- und HBeAg-Test der Firma Sorin Biomedica, Saluggia, Italien)

Der Zellkulturüberstand wurde in $500 \mu 1$ Endvolumen in einer 1:50 Verdünnung zur Vermessung gegeben. Anhand Standardverdünnungen konnte die Konzentration an Antigen abgeschätzt werden.

\subsubsection{Zelllysatherstellung}

Drei bis fünf Tage nach Transfektion von HuH7-, HepG2- oder COS7-Zellen wurde der Zellkulturüberstand abgenommen, für weitere Versuche bei $4{ }^{\circ} \mathrm{C}$ gelagert oder verworfen. Der Zellkulturrasen wurde einmal mit $10 \mathrm{ml}$ PBS/10-cm-Schale, $5 \mathrm{ml}$ PBS/5-cm-Schale bzw. $2 \mathrm{ml}$ PBS/6-well-Napf gewaschen und nachfolgend durch Schrägstellen der Zellkulturplatte restlos vom PBS wieder befreit. Die Zelllysatherstellung erfolgte durch Zugabe von $1 \mathrm{ml}$ COS-Lysispuffer/10-cm-Schale bzw. $500 \mu 1$ COS-Lysispuffer/5 cm-Schale oder pro 6-well-Napf und anschließender Inkubation für 5 Minuten bei Raumtemperatur auf dem Schüttler. Die so hergestellten Zelllysate wurden vor Weiterverwendung für 10 Minuten bei $14000 \mathrm{rpm}$ in der Tischzentrifuge abzentrifugiert, um die Lysate von Zelltrümmern und groben Zellbestandteilen zu trennen. Bis zur Weiterverwendung wurden die Zelllysate auf Eis bei $4{ }^{\circ} \mathrm{C}$ oder $-20{ }^{\circ} \mathrm{C}$ gelagert.

\subsubsection{Fixierung von Zellen für Immunfluoreszenzuntersuchungen}

Zur Fixierung von Zellkulturen für Immunfluoreszenzuntersuchungen wurden die Zellen zunächst transfiziert (3.3.3) und zwei Tage nach der Transfektion auf sterile 
1-cm-Deckgläschen umgesetzt. Die Zellen wurden mit einer Zelldichte von $10^{5}$ Zellen/Deckgläschen zur Fixierung eingesetzt. Für die Untersuchung des membranassoziierten MA18/7-Antikörpers wurden zwei verschiedene Protokolle verwendet. Das eine Protokoll sah eine Permeabilisierung der Zellen mit Saponin vor, um spezifisch Komponenten in der Zelle anfärben zu können, während hingegen auch von Interesse war, die Zytoplasmamembran nichtpermeabilisierter Zellen von außen zu untersuchen. Zum Nachweis von MA18/7 in transfizierten Zellkulturen mittels Immunfluoreszenzuntersuchung konnte auf einen ersten Antikörper verzichtet werden, da MA18/7 ja bereits als Antikörper in den Zellen vorliegt. MA18/7 konnte somit direkt mit einem fluoreszenzmarkierten Konjugat nachgewiesen werden.

Die transfizierten, auf Deckgläschen gewachsenen Zellen wurden zunächst zweimal mit $2 \mathrm{ml}$ PBS gewaschen. Die Fixierung erfolgte durch Inkubation mit 0,5 $\mathrm{ml} 4 \%(\mathrm{v} / \mathrm{v})$ Paraformaldehyd in PBS für 40 Minuten. Anschließend wurden die Zellen wiederum zweimal mit $2 \mathrm{ml}$ PBS gewaschen und für 10 Minuten in $50 \mathrm{mM} \mathrm{NH} \mathrm{NH}_{4}$ in $\mathrm{PBS}$ inkubiert. Es folgte erneutes Waschen mit PBS, bevor die Zellen zur Permeabilisierung dreimal für 5 Minuten mit $2 \mathrm{ml} 0,5 \%(\mathrm{w} / \mathrm{v})$ Saponin in PBS inkubiert wurden. Alternativ wurden die nicht $\mathrm{zu}$ permeabilisierenden Zellen in $2 \mathrm{ml}$ PBS inkubiert. Nach der Inkubationszeit wurden die Lösungen abgenommen und mit dem zweiten Antikörperkonjugat inkubiert: Es wurden $40 \mu 1$ Antikörperlösung eines Cy2konjugierten Esel-Anti-Maus $\operatorname{IgG}(\mathrm{H}+\mathrm{L})$-Antikörpers (Dianova, Hamburg) in der Verdünnung $1: 400$ in PBS bzw. 0,5 \% Saponin/PBS eingesetzt und für eine Stunde bei Raumtemperatur in Dunkelheit inkubiert. Als Schutz vor dem Eintrocknen wurden die Zellkulturplatten in feuchte Tücher eingewickelt. Anschließend folgte ein dreimaliger Waschschritt mit PBS bzw. 0,5\% Saponin/PBS für jeweils 5 Minuten gefolgt von zwei Waschschritten mit $\mathrm{H}_{2} \mathrm{O}$ bidest. Zuletzt wurden die Deckgläschen mit $15 \mu 1$ Moviol versehen auf Objektträger eingedeckelt und für ein paar Stunden getrocknet. Bis zur fluoreszenz-mikroskopischen Untersuchung (Fluoreszenzmikroskop Leica DMR, Jena) wurden die Objektträger dunkel bei $4{ }^{\circ} \mathrm{C}$ gelagert. 


\subsubsection{Inkubation von Zellkulturen mit HBV-Virionen}

\subsubsection{HBV-Bindungsassay}

HuH7- und COS7-Zellen wurden in 6-well-Schalen mit schwerer und leichter Kette des MA18/7-Antikörpers transfiziert (3.3.3). Als Kontrolle wurden Zellen mocktransfiziert. 3 Tage nach Transfektion wurden alle Zellen mit $2 \mu 1$ Patientenserum $\left(\sim 2 \times 10^{6}\right.$ Virionen) für drei Stunden bei $37^{\circ} \mathrm{C}$ und leichtem Schwenken inkubiert. Anschließend wurden die Proben aufgearbeitet (3.3.8.3).

\subsubsection{HBV-Aufnahmeassay}

HuH7- und COS7-Zellen wurden in 6-well-Schalen mit schwerer und leichter Kette des MA18/7-Antikörpers transfiziert (3.3.3). Als Kontrolle wurden Zellen mocktransfiziert. 3 Tage nach Transfektion wurden alle Zellen mit $2 \mu$ l Patientenserum $\left(\sim 2 \times 10^{6}\right.$ Virionen) für drei Stunden bei $37^{\circ} \mathrm{C}$ und leichtem Schwenken inkubiert. Parallel wurde ein gleicher Ansatz zuvor 30 Minuten bei $4{ }^{\circ} \mathrm{C}$ präinkubiert und mit $2 \mu 1$ Patientenserum bei $4{ }^{\circ} \mathrm{C}$ und leichtem Schwenken inkubiert. Die Inkubation bei Kälte sollte hierbei jegliche zellulären Aufnahmemechanismen unterbunden haben. MA18/7transfizierte und mock-transfizierte Zellen wurden anschließend aufgearbeitet. Eine weitere MA18/7-transfizierte, mit Virionen inkubierte Kultur der $37{ }^{\circ} \mathrm{C}$ - und $4{ }^{\circ} \mathrm{C}$ Inkubationen wurden nach fünfmaligem Waschen mit PBS für eine Stunde bei $37^{\circ} \mathrm{C}$ mit $1 \mathrm{ml}$ Trypsin behandelt. Hierbei sollten jegliche in die Zellmembran eingelagerte Proteine entfernt werden. Anschließend wurden die Proben aufgearbeitet (3.3.8.3).

\subsubsection{Aufarbeitung der Proben}

Nach Bindungs- bzw. Aufnahmeassay wurden die Zellen fünfmal mit $2 \mathrm{ml}$ PBS gewaschen und mit $500 \mu 1$ COS-Lysispuffer lysiert. $250 \mu 1$ der Zelllysate wurden dann mit $20 \mathrm{mg}$ Proteinase-K in Proteinase-K-Puffer über Nacht bei $56{ }^{\circ} \mathrm{C}$ verdaut und am nächsten Tag dreimal mit Phenol/Chloroform extrahiert (3.1.4.1) sowie mit Ethanol/Acetat gefällt (3.1.4.2). Die in $250 \mu 1$ TE-Puffer wiederaufgenommene DNA wurde nachfolgend als Template zum PCR-Nachweis (3.1.6.4) eingesetzt. 


\subsubsection{Metabolische pulse/chase-Markierung in Zellkulturen}

Die erfolgreiche Produktion des MA18/7-Antikörpers konnte durch radioaktive metabolische pulse/chase-Markierung in COS7-Zellen gemessen werden. MA18/7transfizierte Zellen wurden 2 Tage nach Transfektion in 6-well-Schalen (3.3.3) zweimal mit $2 \mathrm{ml}$ PBS gewaschen und anschließend mit $0,6 \mathrm{ml} /$ well methionin- und cysteinarmen Medium für 40 Minuten im Brutschrank des Isotopenlabors inkubiert. Zur Substitution und Markierung wurde anschließend $8 \mu 1 /$ well ${ }^{35} \mathrm{~S}$-Methionin/Cystein (Easytag $11 \mu \mathrm{Ci} / \mu 1, \mathrm{NEN}$, Bad Homburg) hinzupipettiert und für 30 Minuten inkubiert. Hiernach wurde das Medium verworfen und durch $1 \mathrm{ml}$ frischen Mediums ersetzt. Es folgte eine erneute Inkubation über Nacht. Am nächsten Tag wurden die Zellen durch Zelllyse geerntet (3.3.6) und sowohl die Medien als auch die Zelllysate mit einem Kaninchen-anti-Maus-Antikörper immunpräzipitiert (3.1.8.1). Die Immunpräzipitate wurden nach drei Stunden dreimal mit PBS gewaschen und daraufhin auf einem 11 \%igen denaturierenden Polyacrylamidgel (3.1.8.2) aufgetrennt. Das Gel wurde dann unter Hitze auf einem Vakuumtrockner getrocknet und durch Auflegen eines Röntgenfilms (Biomax MR, Kodak, New Haven, USA) autoradiographiert. 


\section{ERGEBNISSE}

\subsection{Kartierung umhüllungsrelevanter Aminosäureseitenketten auf der HBV-Kapsidoberfläche}

Einer der letzten Schritte der HBV-Morphogenese in der späten Replikationsphase ist die Umhüllung des reifen Nukleokapsids am Endoplasmatischen Retikulum (ER). Für diesen Schritt wird eine Protein-Protein-Interaktion des Nukleokapsids mit den transmembran eingelagerten Hüllproteinen postuliert. Seitens der Hüllproteine ist bekannt, dass lediglich das kleine (S) und das große (L), nicht aber das mittlere (M) Hüllprotein für eine erfolgreiche Umhüllung benötigt werden (BRUSS und GANEM, 1991). Es besteht die Vorstellung, dass bei der Umhüllung ein linearer Bereich von ca. 22 Aminosäuren (AS 103-124) des großen Hüllproteins direkten Kontakt zum Nukleokapsid aufbaut.

Die Analyse ungerichteter Mutationen des Coreproteins zeigte bereits, dass kurze Deletionen und Insertionen im Coreprotein zum Verlust der Umhüllungskompetenz führen konnten, ohne die Kapsidbildung und die virale DNA-Synthese zu behindern. (Koschel et al., 2000). Es stellte sich heraus, dass vor allem Mutationen im Bereich der C-terminal gelegenen Schleife des Coreproteins einen solchen Phänotyp hervorriefen, während hingegen eine Mutation an der Spitze der spikeartigen Struktur des Coreproteins offenbar nicht zum Verlust der Umhüllung führte.

Ziel dieser Arbeit war eine genaue Analyse des Kapsids hinsichtlich Kontaktstellen, die an der Umhüllung beteiligt sein könnten. Es sollte versucht werden, diejenigen Bereiche des Kapsids zu kartieren, die für eine Interaktion mit den Hüllproteinen während der Umhüllung verantwortlich sind. Bei einer dreidimensionalen Visualisierung des Coreproteins wurden zunächst Aminosäureseitenketten ausgewählt, die außen auf dem Kapsid exponiert sind und somit für einen möglichen Kontakt zu den Hüllproteinen in Frage kamen. Es wurden anschließend 55 einzelne Alaninaustauschmutationen hergestellt und in Zellkultur auf ihre Umhüllungskompetenz getestet. 


\subsubsection{Auswahl der Mutationen mit Hilfe der kristallographischen Daten des Coreproteins}

Das HBV-Kapsid assembliert in infizierten Leberzellen, initiiert durch Bindung des viralen P-Proteins an das terminal redundante $3,5 \mathrm{~kb}$ große virale Prägenom aus Coreproteinhomodimeren (ZHOU und STANDERING, 1992). Zwei verschiedene Partikelformen sind hierbei $\mathrm{zu}$ beobachten. Zum einen $32 \mathrm{~nm}$ Partikel mit $\mathrm{T}=3$ Symmetrie, zusammengesetzt aus 90 Coreproteindimeren und zum anderen Partikel mit $36 \mathrm{~nm}$ Durchmesser und $\mathrm{T}=4$ Symmetrie, zusammengesetzt aus 120 Coreproteindimeren (CROWTHER et al., 1994; WingField et al., 1995; ZlotNiK et al., 1996). Welche der beiden Kapsidspezies tatsächlich in Patientenseren vorkommen ist bisher unklar (KENNEY et al., 1995). Neben der Bildung von Kapsiden in Leberzellen können Kapside auch durch rekombinante Expressionen des Coreproteins hergestellt werden. Spontane Bildung von Kapsiden ohne die Anwesenheit anderer Virusproteine wurde in Bakterien (COHEN und RichmOND, 1982), in Xenopus Oozyten (ZHOU und STANDERING, 1991) und in Insektenzellen beobachtet (LANFORD und NOTVAL, 1990).

Ein erstes Strukturmodell des Nukleokapsids entstand 1994 aus cryoelektronenmikroskopischen Daten von Kapsiden, die in E. coli rekombinant durch eine C-terminal um 39 Aminosäuren verkürzten Coreproteinvariante hergestellt wurden (CROWTHER et al., 1994). Es folgten ebenfalls auf cryomikroskopischer Technik basierend Strukturanalysen zur Faltung des Coreproteins mit einer Auflösung von 7,4 $\AA$ (BÖTTCHER et al., 1997), Analysen zur Anordnung des 4-Helixbündels, das als spikeartige Struktur aus dem Kapsid herausragt (CONWAY et al., 1997) sowie Untersuchungen zur Multimerisierung der Coreproteindimere (KöNIG et al., 1998). 1999 erschien die Veröffentlichung einer Kristallstruktur des HBV-Kapsids in einer Auflösung von $3.3 \AA$ (WYNNE et al., 1999). Hier wurde ebenfalls eine in E. coli rekombinant exprimierte C-terminal verkürzte Coreproteinvariante (aa $1-149)$ verwendet. Diese Kristallstrukturdaten dienten als Grundlage der Strukturanalyse dieser Arbeit. Unter dem Gesichtspunkt oberflächenexponierter, von der Außenseite des Kapsids zugänglicher Aminosäureseitenketten sollten zunächst Kandidaten für eine Mutagenese ausgewählt werden. Es wurde hierfür der Kristallstrukturdatenfile „1qgt.pdb“ im pdbFormat aus der „ProteinDataBank“-Datenbank (http://www.rcsb.org/pdb/) bezogen 
und mit der 3D-Visualisierungssoftware Swiss-PdbViewer (GalaxoSmithKline R\&D, http://us.expasy.org/spdbv/mainpage.html) näher analysiert. Die Software erlaubte es, sowohl das Peptidgrundgerüst als auch die Aminosäureseitenketten in verschiedener Weise, z.B. als raumfüllendes Kugelmodell oder Strichmodell, darzustellen sowie beliebig ausgewählte Aminosäuren des Peptids anzuzeigen oder auszublenden. Der Kristallstrukturdatenfile enthielt die Werte für zwei benachbarte Coreproteinhomodimere. So konnten sowohl die Kontaktpunkte der Monomere als auch der Interdimerkontakt zweier Dimere dreidimensional im Raum betrachtet werden. Es wurde zunächst jede der 149 Aminosäuren für sich einzeln hinsichtlich der Exposition der Seitenkette nach außen sowie ihre Position im Monomer und Dimer begutachtet. Strenges Kriterium waren hierbei eine von außerhalb des Kapsids gut zugängliche Position der Aminosäure sowie die freie Exposition der Seitenkette nach außen. Ausschlusskriterien stellten zunächst u.a. Eigenschaften wie Beteiligungen an Sekundär- und Tertiärstrukturen oder intra- und intermolekulare Bindungen dar. Aminosäurepositionen, deren Wasserstoffbrückenbindungen offenbar zum Strukturerhalt beitrugen, wurden in Einzelfällen nur bedingt als Kandidaten für eine Punktmutagenese ausgewählt. Ziel sollte es zunächst sein, einen möglichst ohne größeren strukturellen Eingriff in den Aufbau des Dimers punktuellen Austausch zu Alanin zu erlangen. Weitere Schritte hatten eine genauere Charakterisierung dieser Alaninsubstitutionen hinsichtlich Kapsidassemblierung, Prägenomverpackung, DNASynthese und Umhüllungskompetenz zum Ziel.

Abb. 12 zeigt das Vorgehen der Positionsanalyse aller 149 Aminosäureseitenketten anhand eines Beispiels (Aminosäure Arginin 133). Im Teilbild a ist Arginin 133 als einzeln markierte Aminosäure in der prolinreichen Schleife nahe des C-Terminus dargestellt. Die Seitenkette weist nach oben in Richtung Spitze des Spikes, das Lumen des Kapsids befindet sich jeweils unterhalb der Strukturen. Teilbild b zeigt Arginin 133 im Kontext benachbarter Aminosäuren innerhalb des Coredimers. Der Rest wird durch keine anderen Strukturen nach außen hin verdeckt. Die Kontaktstellen zweier Dimere verdecken teilweise großflächig Strukturen der C-Termini. Hier musste anschließend überprüft werden, ob Seitenketten, die im Dimer frei zugänglich schienen, nicht durch Interdimerkontakte verdeckt würden und damit ausgeschlossen werden mussten. Die Teilbilder c und d zeigen jeweils das räumliche Verhältnis von Arginin 133 zum 
benachbarten Dimer. Auch durch das benachbarte Dimer (links) wird Arginin 133 nicht nennenswert verdeckt.

54 der insgesamt 149 Aminosäuren wurden nach Analyse der Coreproteinkristallstruktur mit den oben aufgeführten Kriterien für eine Mutagenese selektioniert. Sie sind nachfolgend in Tabelle 1 aufgelistet sowie graphisch in Abbildung 13 dargestellt. In den Abbildungen 13 ist deutlich zu erkennen, dass der überwiegende Teil aller nach außen ragenden Aminosäureseitenketten als Kandidaten für eine Alaninsubstitution ausgewählt wurden: Praktisch die gesamte äußere Oberfläche des Coreproteins in der Zwei-Dimeransicht der Teilabbildungen $\mathrm{c}$ und $\mathrm{d}$ ist durch die für die Mutagenese ausgewählten Kandidaten abgedeckt. 

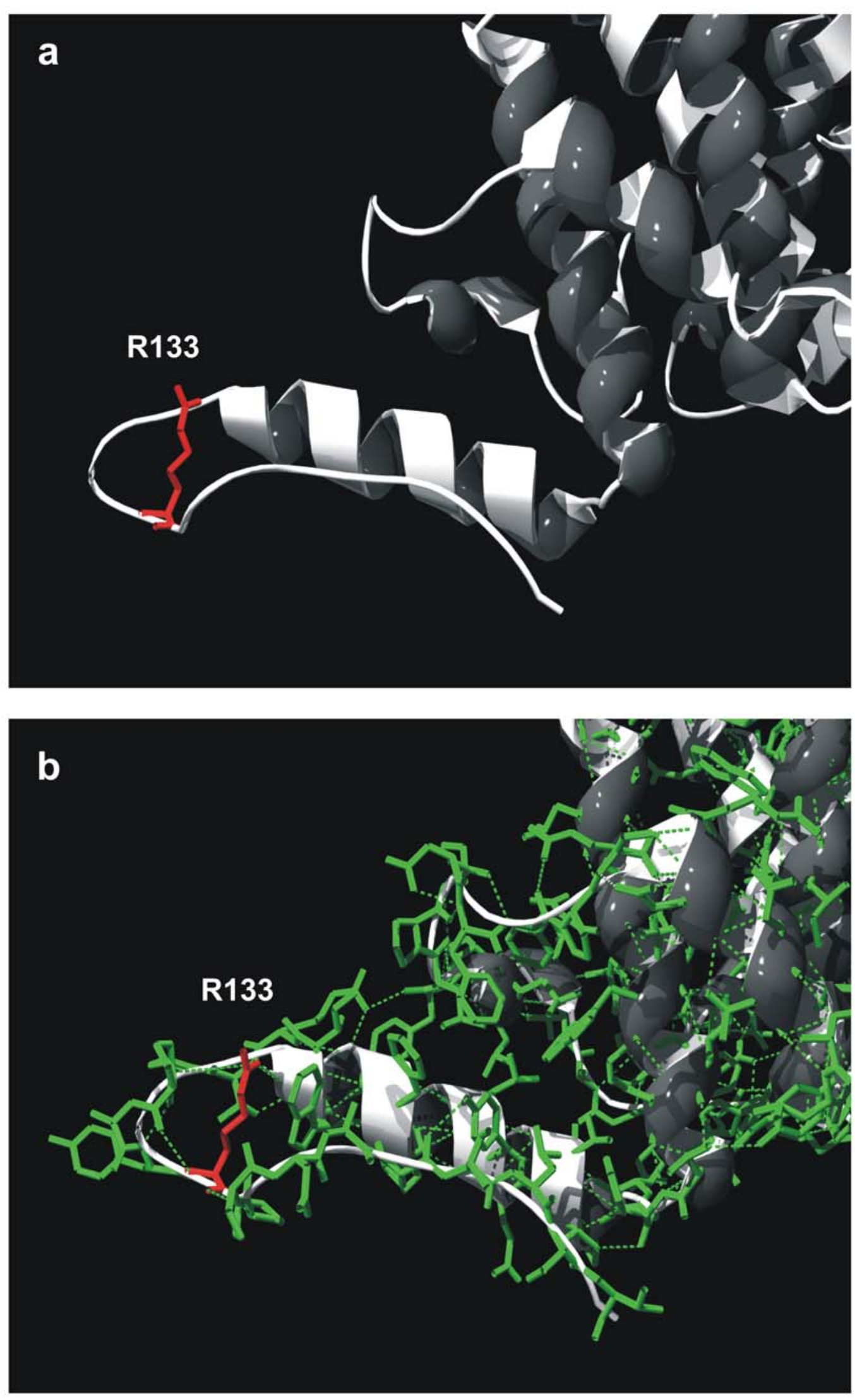

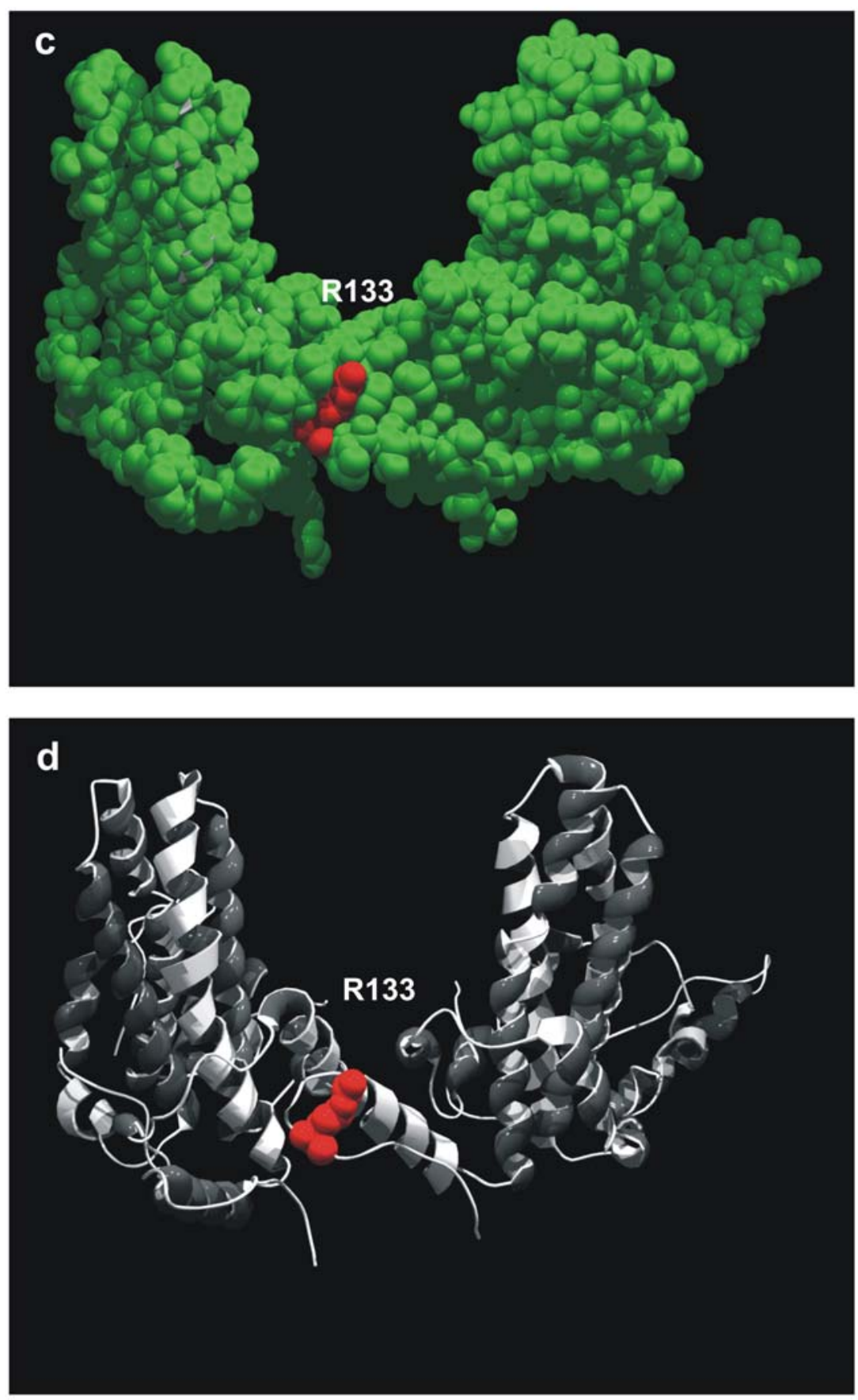

Abb. 12: Darstellung des Vorgehens bei der Positionsanalyse aller 149 Aminosäuren unter Verwendung kristallographischer Daten anhand des Kandidaten Arginin 133. Arginin 133 ist als Kugel- und Stiftdarstellung in Rot eingezeichnet. Alle anderen Aminosäuren sind mit ihren Seitenketten in Grün dargestellt. Alle Abbildungen stellen Seitenansichten der C-terminalen Schleife des Monomers (a und b) oder zweier Dimere (c und d) dar. Teilabbildung a zeigt die Orientierung von R133 nach außen. Teilabbildung b zeigt den Verbund der Aminosäure im Coredimer. Die Teilabbildungen c und d zeigen, dass R133 auch durch Interdimerkontakt nicht verdeckt wird. 
Tab. 1: Auflistung der 54 aus 149 Aminosäuren ausgewählten Kandidaten für einzelne Alaninsubstitutionen und ihre Positionen im Coreprotein.

\begin{tabular}{|c|c|c|c|}
\hline \multicolumn{2}{|c|}{ Aminosäure } & \multicolumn{2}{|r|}{ Position } \\
\hline 2 & $\mathrm{D}$ & & lateral basaler \\
\hline 4 & $\mathrm{D}$ & & Loop \\
\hline 13 & $\mathrm{~V}$ & $\alpha 1$ & \\
\hline 14 & $\mathrm{E}$ & $\alpha 1$ & \\
\hline 17 & $\mathrm{~S}$ & $\alpha 1$ & \\
\hline 18 & $\mathrm{~F}$ & & \\
\hline 20 & $\mathrm{P}$ & & \\
\hline 21 & $\mathrm{~S}$ & & \\
\hline 22 & $\mathrm{D}$ & & \\
\hline 26 & $\mathrm{~S}$ & & \\
\hline 27 & $\mathrm{~V}$ & $\alpha 2 a$ & laterale Helix \\
\hline 28 & $\mathrm{R}$ & $\alpha 2 a$ & \\
\hline 29 & $\mathrm{D}$ & $\alpha 2 a$ & \\
\hline 31 & $\mathrm{~L}$ & $\alpha 2 a$ & \\
\hline 32 & $\mathrm{D}$ & $\alpha 2 a$ & \\
\hline 59 & I & $\alpha 3$ & Spike \\
\hline 60 & $\mathrm{~L}$ & $\alpha 3$ & aufwärts \\
\hline 62 & $\mathrm{~W}$ & $\alpha 3$ & \\
\hline 66 & $\mathrm{M}$ & $\alpha 3$ & \\
\hline 67 & $\mathrm{~T}$ & $\alpha 3$ & \\
\hline 70 & $\mathrm{~T}$ & $\alpha 3$ & \\
\hline 73 & $\mathrm{G}$ & $\alpha 3$ & \\
\hline 74 & $\mathrm{~N}$ & & Spitze des \\
\hline 75 & $\mathrm{~N}$ & & Spikes \\
\hline 76 & $\mathrm{~L}$ & & \\
\hline 77 & $\mathrm{E}$ & & \\
\hline 78 & $\mathrm{D}$ & & \\
\hline
\end{tabular}

\begin{tabular}{|c|c|c|c|}
\hline \multicolumn{2}{|c|}{ Aminosäure } & \multicolumn{2}{|c|}{ Position } \\
\hline 79 & $\mathrm{P}$ & $\alpha 4 \mathrm{a}$ & Spike \\
\hline 82 & $\mathrm{D}$ & $\alpha 4 \mathrm{a}$ & aufwärts \\
\hline 83 & $\mathrm{D}$ & $\alpha 4 a$ & \\
\hline 84 & $\mathrm{~L}$ & $\alpha 4 \mathrm{a}$ & \\
\hline 87 & $\mathrm{~N}$ & $\alpha 4 \mathrm{a}$ & \\
\hline 90 & $\mathrm{~N}$ & & \\
\hline 91 & $\mathrm{~T}$ & & \\
\hline 92 & $\mathrm{~N}$ & $\alpha 4 b$ & \\
\hline 95 & $\mathrm{~L}$ & $\alpha 4 b$ & \\
\hline 96 & $\mathrm{~K}$ & $\alpha 4 b$ & \\
\hline 98 & $\mathrm{R}$ & $\alpha 4 b$ & \\
\hline 118 & $\mathrm{Y}$ & $\alpha 5$ & vorstehende \\
\hline 119 & $\mathrm{~L}$ & $\alpha 5$ & Helix \\
\hline 122 & $\mathrm{~F}$ & $\alpha 5$ & \\
\hline 125 & $\mathrm{~W}$ & $\alpha 5$ & \\
\hline 126 & $\mathrm{I}$ & $\alpha 5$ & \\
\hline 127 & $\mathrm{R}$ & $\alpha 5$ & \\
\hline 129 & $\mathrm{P}$ & & Schleife \\
\hline 130 & $\mathrm{P}$ & & \\
\hline 131 & $\mathrm{~A}$ & & \\
\hline 132 & $\mathrm{Y}$ & & \\
\hline 133 & $\mathrm{R}$ & & \\
\hline 135 & $\mathrm{P}$ & & \\
\hline 136 & $\mathrm{~N}$ & & \\
\hline 137 & A & & C-terminale \\
\hline 139 & I & & Schleife \\
\hline 140 & $\mathrm{~L}$ & & \\
\hline
\end{tabular}



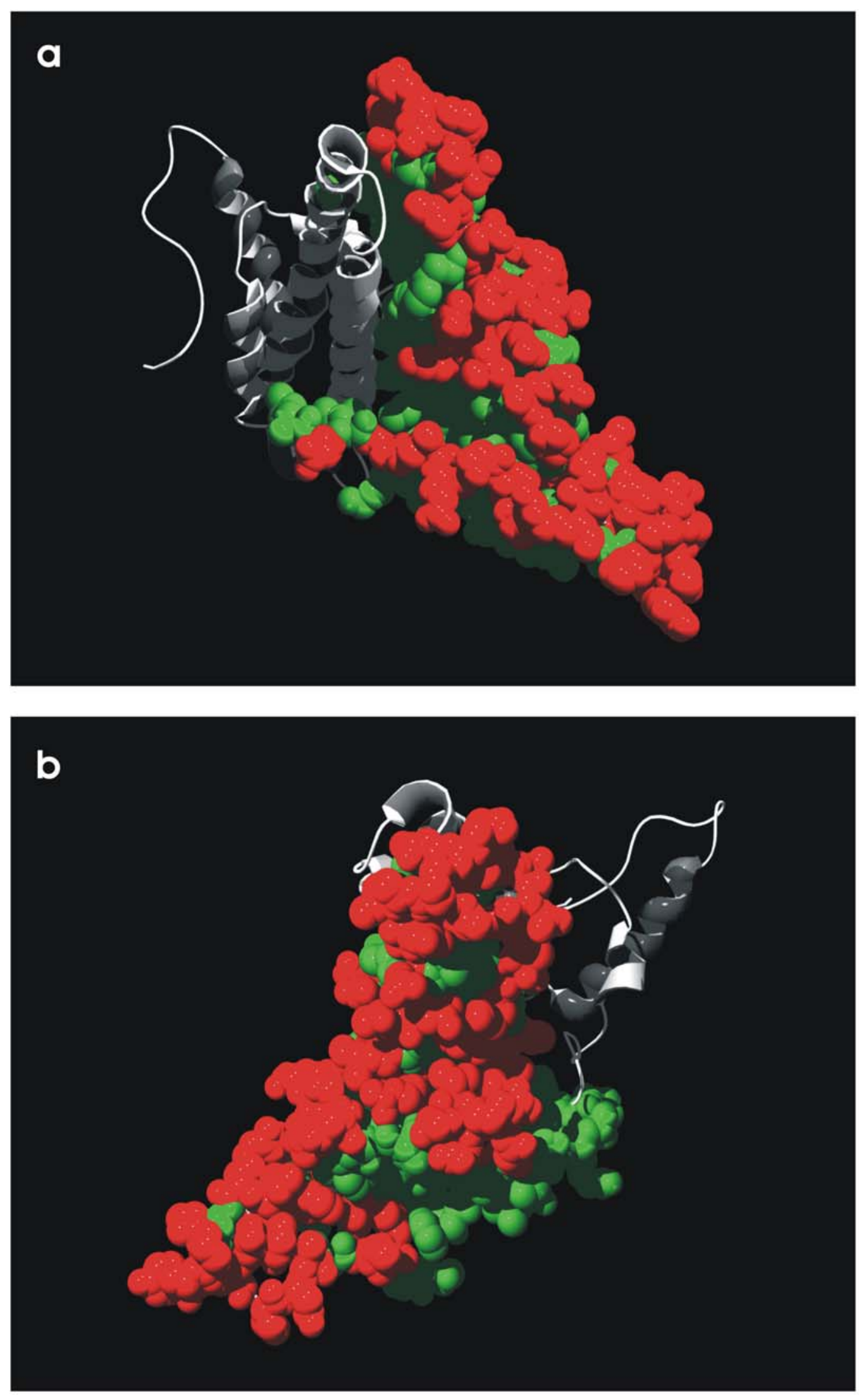

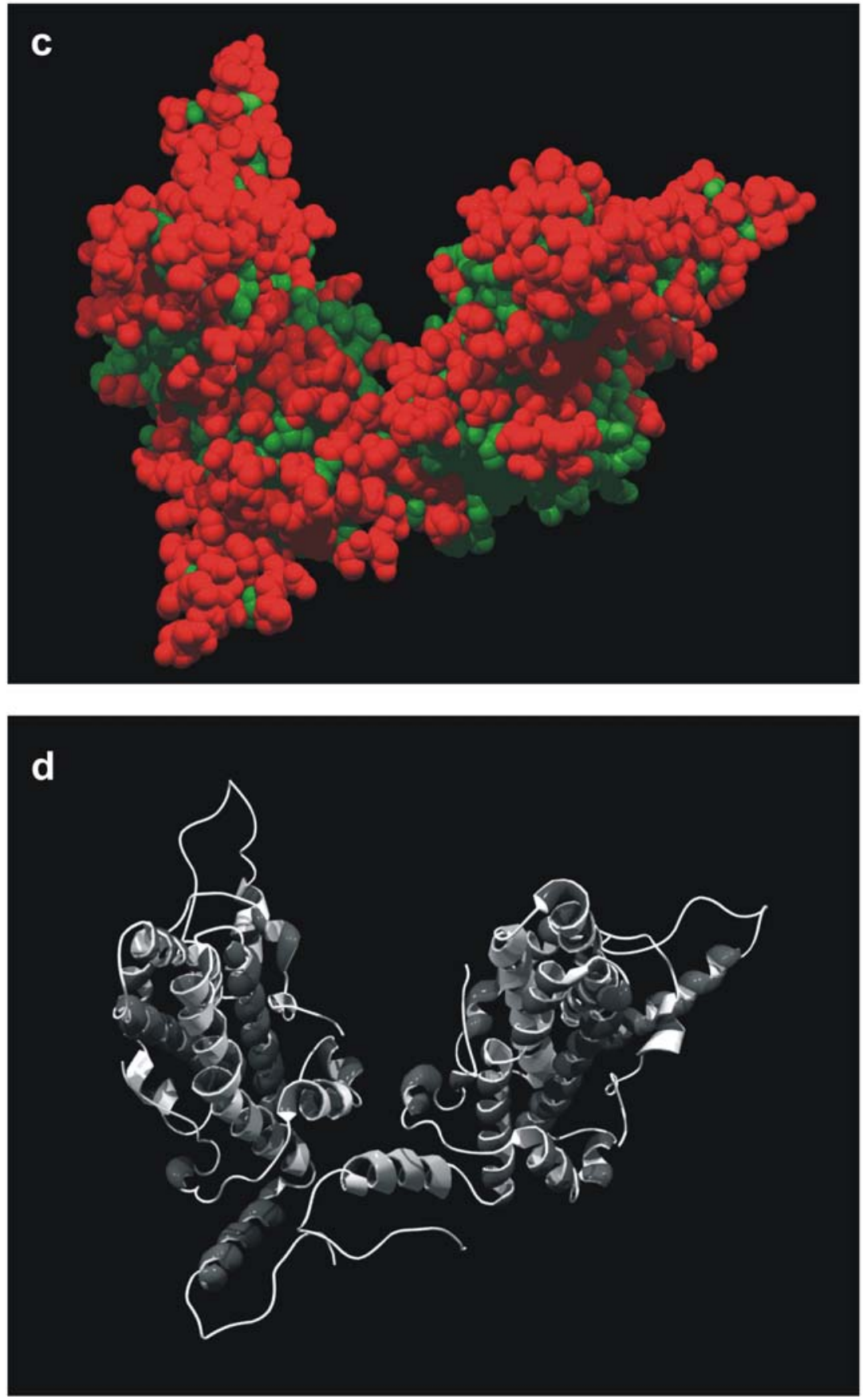

Abb. 13: Darstellung der Position aller 54 ausgewählten Kandidaten für eine Alaninsubstitution im Coreprotein. Die ausgewählten Aminosäuren sind mit ihren Seitenketten als rote Kugelmodelle eingezeichnet, alle anderen Aminosäuren sind in Grün dargestellt. Teilabbildungen a und $\mathrm{b}$ zeigen jeweils die Vorder- und Rückansichten auf ein Coreproteindimer aus einem ca. $45^{\circ}$ Winkel. Teilabbildungen $\mathrm{c}$ und d stellen Aufsichten von der Außenseite zweier Coreproteindimere dar. Man kann deutlich erkennen, dass der überwiegende Teil der die Oberfläche des Kapsids bildenden Aminosäuren als Kandidaten für eine Alaninsubstitution ausgewählt wurden. 


\subsubsection{Herstellung der Coremutanten}

Die im vorangegangenen Abschnitt ausgewählten Aminosäuren des Coreproteins sollten nun einzeln verändert werden, dass ein Funktionsausfall jeder einzelnen Aminosäureseitenkette erreicht wird, um anschließend ihre Umhüllungskompetenz in Zellkultur zu testen. Ein Ausfall der Umhüllungskompetenz nach Substitution einer Seitenkette der oben definierten Kandidaten würde eine Beteiligung dieser Position auf dem Kapsid am Umhüllungsprozess rückschließen lassen, wenn gleichzeitig alle anderen an der Bildung des Nukleokapsids beteiligten Prozesse, wie z.B. die virale DNA-Synthese, unbeeinträchtigt wären. Als Aminosäure zur Substitution ist Alanin gewählt worden, da diese Aminosäure mit einer Methylgruppe als Seitenkette eine größtmögliche neutrale Position hinsichtlich Bindungen zu anderen Aminosäuren über die Seitenkette einnimmt. Die Kandidaten Alanin 131 und Alanin 137 sollten zu Glycin substituiert werden.

Als Expressionssystem für die später in der eukaryotischen Zellkultur vorgesehene Charakterisierung der Mutanten wurde folgendes Komplementationssystem verwendet: Da die prägenomische RNA größer als das HBV-Genom ist und bei der Transkription über den Startpunkt hinaus zieht, diente das Plasmid pSVHBV1.5core mit einer $^{-}$ 1,5-fachen Kopie des HBV-Genoms als Expressionsplasmid aller viralen Proteine sowie des viralen Prägenoms mit Ausnahme des Coreproteins, welches mit einem Stopkodon an Position 38 versehen war. Mutationen im Coregen dieses Plasmids können durch funktionelle Doppelbelegung der Basenpaare mit dem Polyadenylierungssignal, der DRI-Region und dem 5'-Bereich des Polymerasegens zu sekundären Beschädigungen dieser viralen Komponenten führen. Es wurde deshalb ein zweites Plasmid (pSVcore) für die Expression des Coregens zur Komplementation der Coremutation von pSVHBV1.5 core $^{-}$in trans verwendet. In dieses Plasmid wurden die Mutationen eingeführt.

Alle Coremutanten wurden in vitro durch PCR hergestellt (3.1.2.1). Als Matrize diente das Plasmid pSVcore (2.5). Für jeden Aminosäureaustausch wurde ein eigenes Oligonukleotid benutzt und je nach Orientierung mit den flankierenden Oligonukleotiden \#0150, welches 5' vom Coregen hybridisiert bzw. \#0244, das 3' vom Coregen hybridisiert, zur Amplifikation verwendet. Abb. 14 zeigt ein Schema der 
Herstellung der Coremutanten. In Abb. 15 sind exemplarisch PCR-Produkte dargestellt. In einer ersten PCR-Reaktion wurde hierbei der sog. Megaprimer hergestellt, der somit bereits die Mutation trug. Um die Oligonukleotide abzureinigen, wurde der DNAMegaprimer anschließend auf einem präparativen Agarosegel aufgetrennt (3.1.4.6) und mittels Qiagen-Gel-Extraction-Kit aufgereinigt (3.1.4.4). Für die zweite PCR-Reaktion zum Auffüllen des 5' vom Mutageneseoligonukleotid gelegenen Sequenzbereichs kam zur bereits beschriebenen Matrize pSVcore der aufgereinigte Megaprimer sowie das zweite 5 ' flankierende Oligonukleotid zum Einsatz. Das so entstandene zweite PCRProdukt musste nachfolgend vor der Klonierung von dem als Matrize eingesetzten Plasmid pSVcore abgereinigt werden, um Verunreinigungen mit wt-Coresequenz zu vermeiden. Dies geschah wiederum durch präparative Agarosegelelektrophorese (3.1.4.6) mit anschließender Gelextraktion (3.1.4.4). Im Bedarfsfall wurde bei zu geringer Produktausbeute eine dritte PCR zur Amplifikation des zweiten PCR-Produkts unter Einsatz des zweiten PCR-Produkts als Matrize und beider flankierender Oligonukleotide \#0150 und \#0244 durchgeführt.

Die nachfolgende Klonierung des mittels PCR mutagenisierten Coregens in das Plasmid pSVcore erfolgte über die Restriktionsschnittstellen BamHI und BstEII, die sich jeweils innerhalb der flankierenden Oligonukleotide befanden. Es wurde somit der 932 bp große Sequenzbereich zwischen Position 2272 bp und 1340 bp in pSVcore durch das bis auf die Mutation identische DNA-Fragment ausgetauscht (dargestellt als core*). Der Sequenzbereich von 2333 bp bis 1640 bp in pSVcore*, der das gesamte Coregen jeder hergestellten Coremutante enthielt, wurde anschließend durch Sequenzanalyse (3.1.5) hinsichtlich der eingefügten Mutation und der Richtigkeit der Gesamtsequenz mit den Oligonukleotiden \#0177 und \#0178 überprüft (3.1.5). Die Plasmid-DNA der durch Sequenzierung als fehlerfrei bestätigten Coremutanten wurde daraufhin im präparativen Maßstab für Zellkulturexperimente hergestellt (3.1.3.3; 3.1.3.4).

\footnotetext{
Abb. 14 (nächste Seite): Vorgehen bei der Herstellung der Coremutanten. In einer ersten PCR wurde mit einem Mutageneseoligonukleotid sowie einem flankierenden Oligonukleotid die Mutation in das Coregen eingefügt. Das so entstandene Teilstück wurde durch eine zweite PCR bis zu einem zweiten flankierenden Oligonukleotid aufgefüllt und über die Restriktionsschnittstellen BamHI und BstEII in den Vektor pSVcore* rekloniert. Das Coregen aller Mutanten wurde anschließend unter Verwendung der Oligonukleotide \#0177 und \#0178 durchsequenziert.
} 

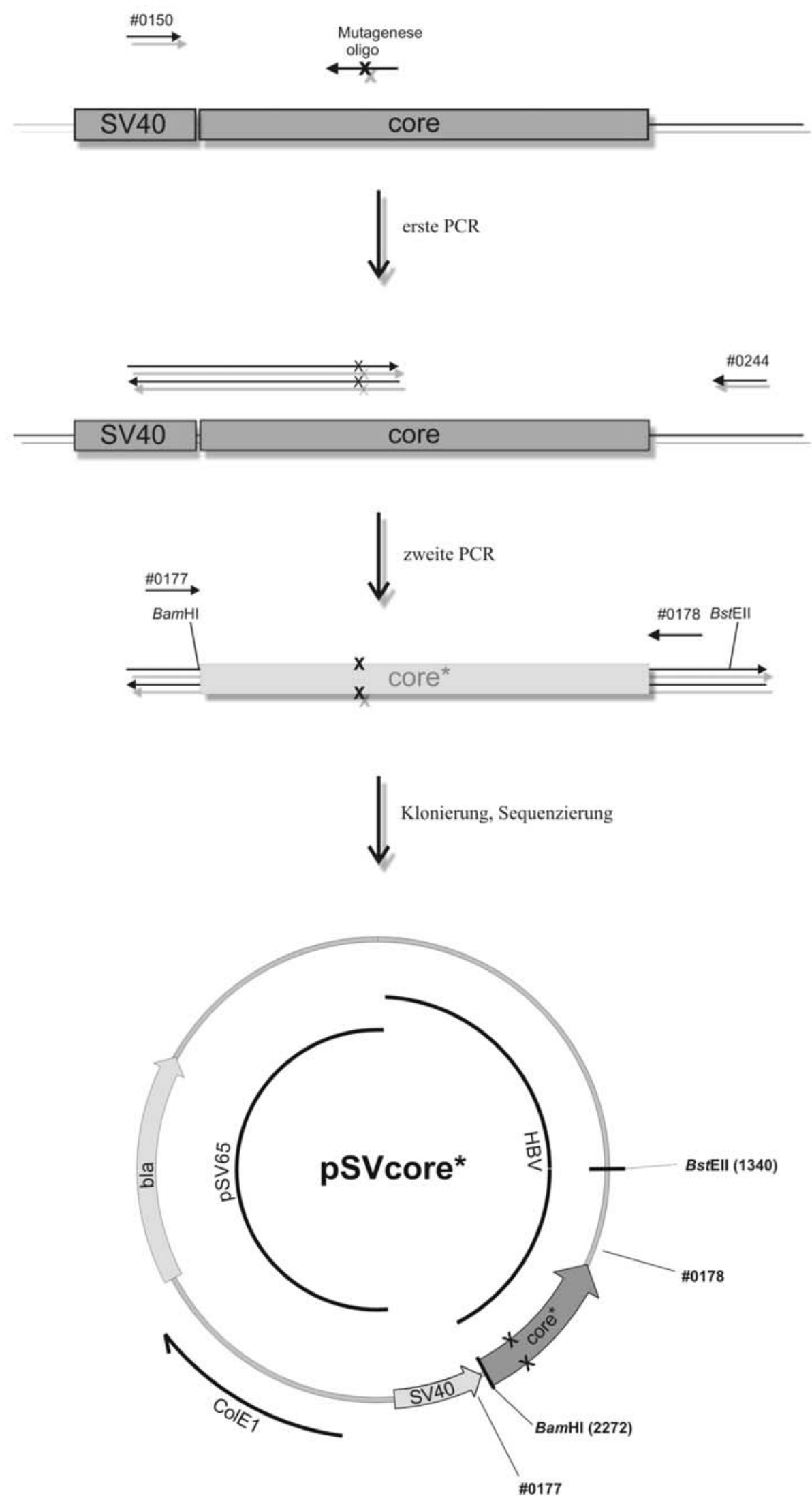
a)

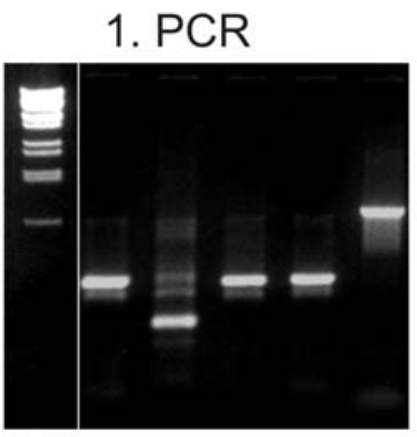

L60 D4 W62 M66 R28

b)

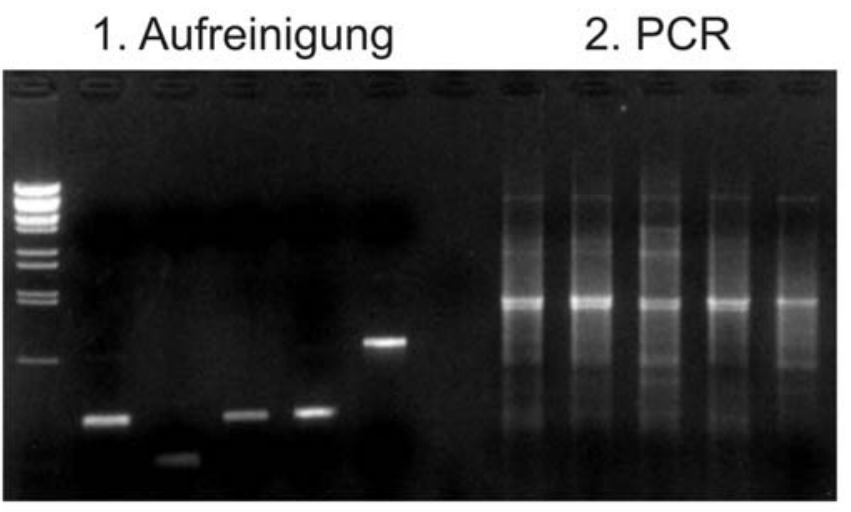

L60 D4 W62 M66 R28

L60 D4 W62 M66 R28

c)

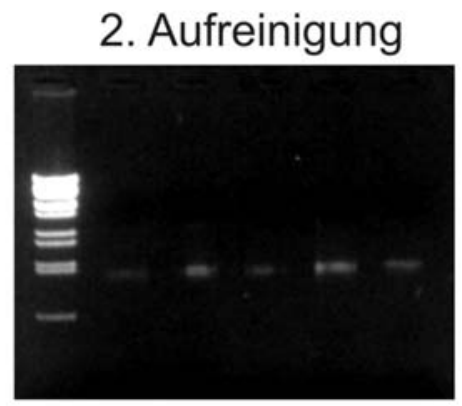

$\begin{array}{lllll}\text { L60 D4 W62 M66 R28 } & \text { W6 }\end{array}$

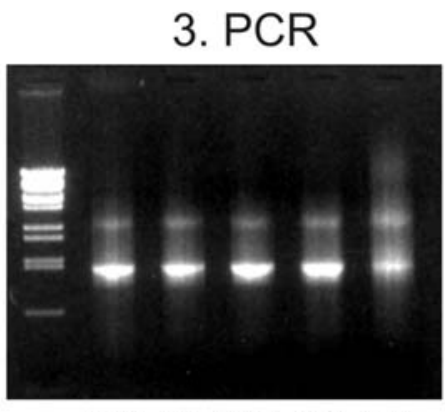

L60 D4 W62 M66 R28

Abb. 15: PCR-Produkte während der Herstellung von Coremutanten, beispielhaft anhand der Mutanten L60A, D4A, W62A, M66A und R28A dargestellt. Teilabbildung a) zeigt die Produkte der ersten PCR (Megaprimer). Die ersten vier Mutanten wurden mit \#0150, R28 mit \#0248 als erstes flankierendes Oligonukleotid hergestellt. Die Teilabbildung b) zeigt auf der linken Seite die Megaprimer nach Aufreinigung sowie auf der rechten Seite die Produkte nach Auffüllen durch die zweite PCR. In der Teilabbildung c) sind auf der linken Seite die Produkte der 2. PCR nach Aufreinigung dargestellt. Aufgrund der geringen Produktausbeute wurde eine weitere dritte PCR-Runde durchgeführt, deren Ergebnis auf der rechten Seite gezeigt ist. Alle PCR-Produkte wurden anschließend über die Restriktionsschnittstellen BamHI und BstEII in das Plasmid pSVcore* kloniert. 


\subsubsection{Test der Coremutanten auf Umhüllungskompetenz}

Ein einfacher und aussagekräftiger Test der im vorherigen Abschnitt beschriebenen Coremutanten auf ihre Umhüllungskompetenz ist der Nachweis von viraler HBV-DNA im Medium transfizierter Zellen mittels endogener Polymerase-Reaktion (EPR) (3.1.6.2). Die endogene Polymerase-Reaktion erlaubt es, spezifisch HBV-ccc-DNA von Nukleokapsiden aus Zelllysaten und Virionen aus Zellkulturüberständen nachzuweisen. Bietet man Nukleokapsiden oder Virionen unter Gabe von Detergenz radioaktiv markierte Nukleotide an, so werden diese durch die endogene virale Polymerase in das partiell doppelsträngige DNA-Genom eingebaut, wodurch es zur Markierung kommt.

Von besonderem Interesse für das Projekt waren Coremutanten, die EPR-positive Nukleokapside im Zelllysat hervorbringen konnten, jedoch nicht mehr in der Lage waren, Virionen in den Kulturüberstand zu entlassen. Dieser Phänotyp würde auf einen spezifischen Block der Umhüllungsreaktion nach Veränderung der Kapsidoberfläche hindeuten.

Alle coremutantentragenden Plasmide pSVcore* wurden mit dem Plasmid pSVHBV1.5 core $^{-}$kotransfiziert, welches eine überlange Kopie des HBV-Genoms trug. Codon 38 des Coregens war $\mathrm{zu}$ einem Stopcodon verändert, so dass nur eine Komplementation dieses Defekts zur Bildung von Kapsiden führen konnte. Die 1,5-fache Kopie des HBV-Genoms befindet sich hierbei unter SV40-Promotorkontrolle, das 5'-Ende des Transkripts entspricht dem natürlichen 5'-Ende der prägenomischen RNA, wie sie natürlicherweise vom endogenen Promotor transkribiert wird. Damit eine gleiche Gendosis auf Transkriptionsebene erreicht werden konnte, wurde in gleicher Weise die Transkription des Coregens in pSVcore unter SV40-Promotorkontrolle verwendet.

Drei bis fünf Tage nach Kotransfektion von HuH7-Zellen mit den Plasmiden pSVHBV1.5 core $^{-}$und den coremutantenexprimierenden Plasmiden pSVcore* wurden die Zellen geerntet und Zelllysate hergestellt (3.3.6). Es folgten Immunpräzipitationen von Virionen aus den Zellkulturüberständen mit anti-HBs-Antiserum $(\alpha S)$ und Nukleokapsiden aus den Zelllysaten mit anti-HBc-Antiserum $(\alpha \mathrm{C})$ (3.1.8.1). Beide Antiseren waren polyklonal. Das anti-HBc-Antiserum aus dem Kaninchen (Dako, Hamburg) enthielt hierbei Antikörper, die gegen zwei verschiedene Epitope gerichtet waren. So 
sollten Coremutanten, die ihre Mutation innerhalb eines Epitops trugen, trotzdem erfolgreich über das zweite Epitop immunpräzipitiert werden können. Die Immunpräzipitate wurden anschließend für die EPR eingesetzt (3.1.6.2). Nach Aufreinigung der radioaktiv markierten viralen DNA (3.1.6.3) wurden die Proben auf einem Agarosegel elektrophoretisiert, unter Hitze und Vakuum getrocknet und autoradiographiert. Alle Daten wurden mindestens zweimal reproduziert.

In Abb. 16 sind die Autoradiogramme dargestellt. Auf der rechten Seite in den unteren Spuren der Abbildung befinden sich die Ergebnisse von Kontrollexperimenten. Als Positivkontrolle ist $1 \mu \mathrm{l}$ eines Serums eines hochtitrigen HBV-Patienten mit etwa $10^{6}$ Virionen in die EPR zum Einsatz gekommen. Transfektion des corenegativen Genoms pSVHBV1.5 core ${ }^{-}$allein hat zu keinem Signal geführt, ist aber erfolgreich in trans durch Transfektion von pSVcore komplementiert worden, wie Spur WT deutlich macht. Mit $\mathrm{LE}^{-}$ist die Spur bezeichnet worden, in der eine Mutante eingesetzt worden ist, die aufgrund einer Mutation im großen Hüllprotein umhüllungsinkompetent gewesen ist. Diese Kontrolle zeigt, dass das Signal im Medium nicht durch aus den Zellen freigesetzte nackte Kapside verursacht wird.

Die Charakterisierung der Phänotypen ließ sich in drei verschiedene Klassen einteilen. Der überwiegende Anteil (30 Mutanten) verhielt sich wie die Komplementation durch pSVcore-Wildtyp. Die Mutanten zeigten sowohl Signale von Nukleokapsiden aus den Zelllysaten als auch deutliche Signale von Virionen aus den Zellkulturüberständen $(\mathrm{K}+\mathrm{V}+)$. Die Signalverhältnisse Virionen/Nukleokapside variierten nach Quantifizierung zwischen 0,07 (R28) und 1,5 (D83). Signalverhältnisse über 0,02 wurden noch als nicht vollständiger Umhüllungsblock interpretiert. Bei 13 Mutanten führte die Mutation offenbar zu einem Verlust der Bildung reifer Nukleokapside. Sie zeigten weder in den Zelllysaten noch in den Kulturüberständen Signale markierter viraler DNA $(\mathrm{K}-\mathrm{V}-)$. Hier musste davon ausgegangen werden, dass die eingefügten Mutationen in einem der früheren Prozesse der Kapsidbildung bzw. der Genomreifung Defekte hervorgerufen hatten. Die dritte und für diese Aussage interessanteste Klasse beinhaltete den gesuchten Phänotyp. Elf Mutanten zeigten ein deutliches Signal viraler DNA nach Immunpräzipi-tation von Nukleokapsiden aus Zelllysaten bei fehlendem Signal nach Immunpräzipi-tation von Virionen aus Zellkulturüberständen. Das Signalverhältnis Virionen/ Nukleokapside nach Quantifizierung lag in dieser Klasse unter 0,02. 

굿ำ

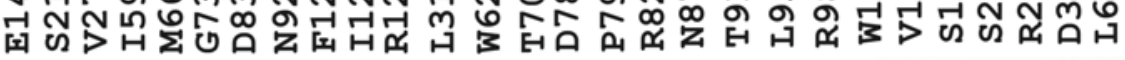
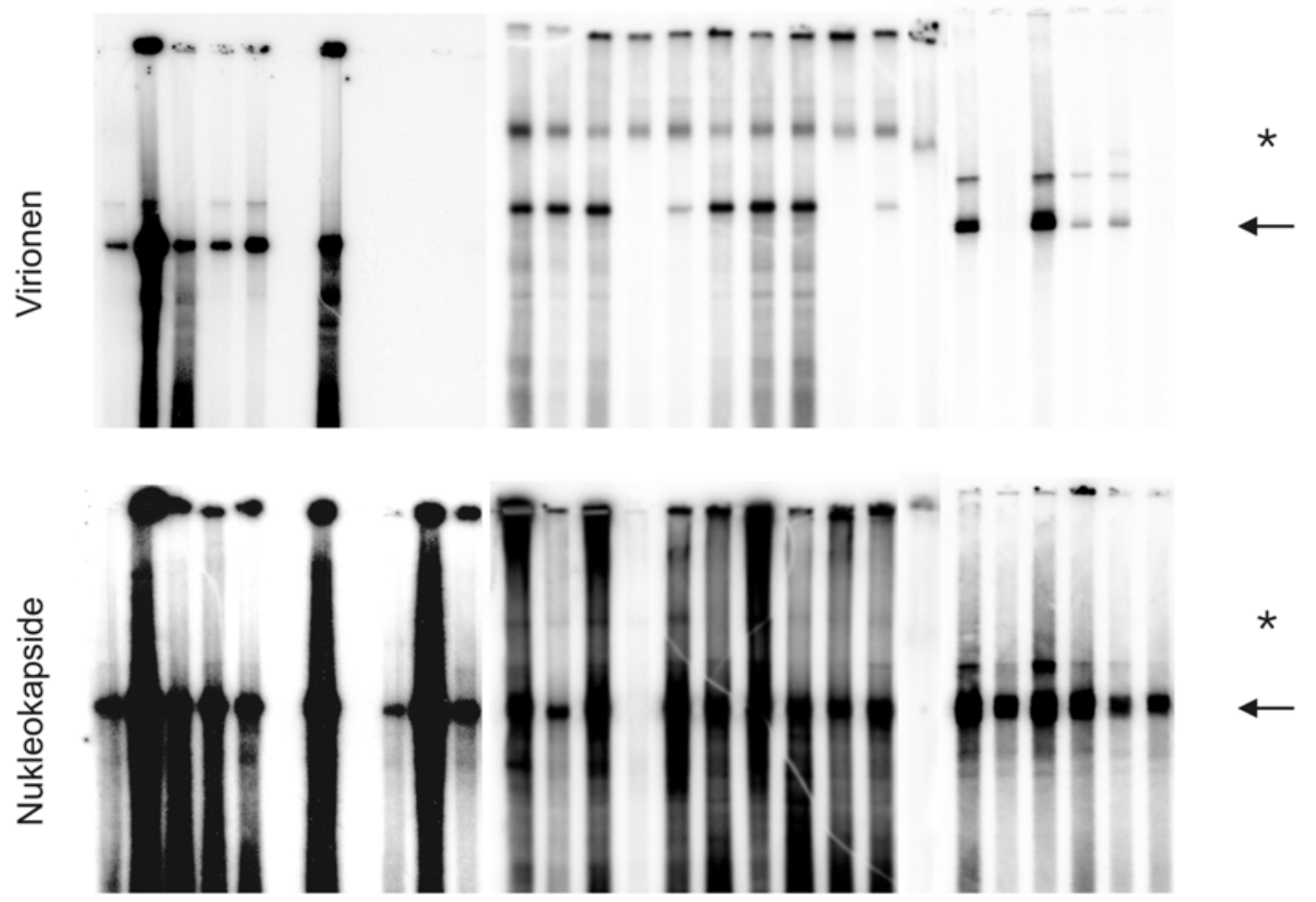

*

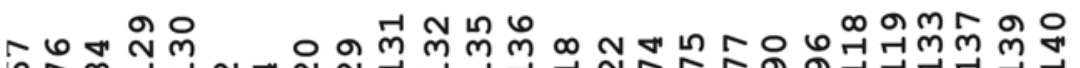

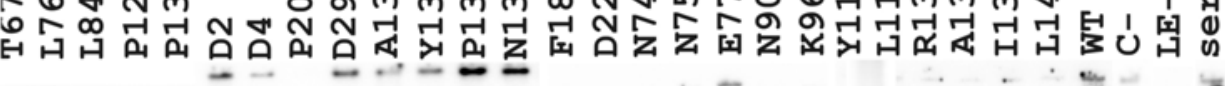
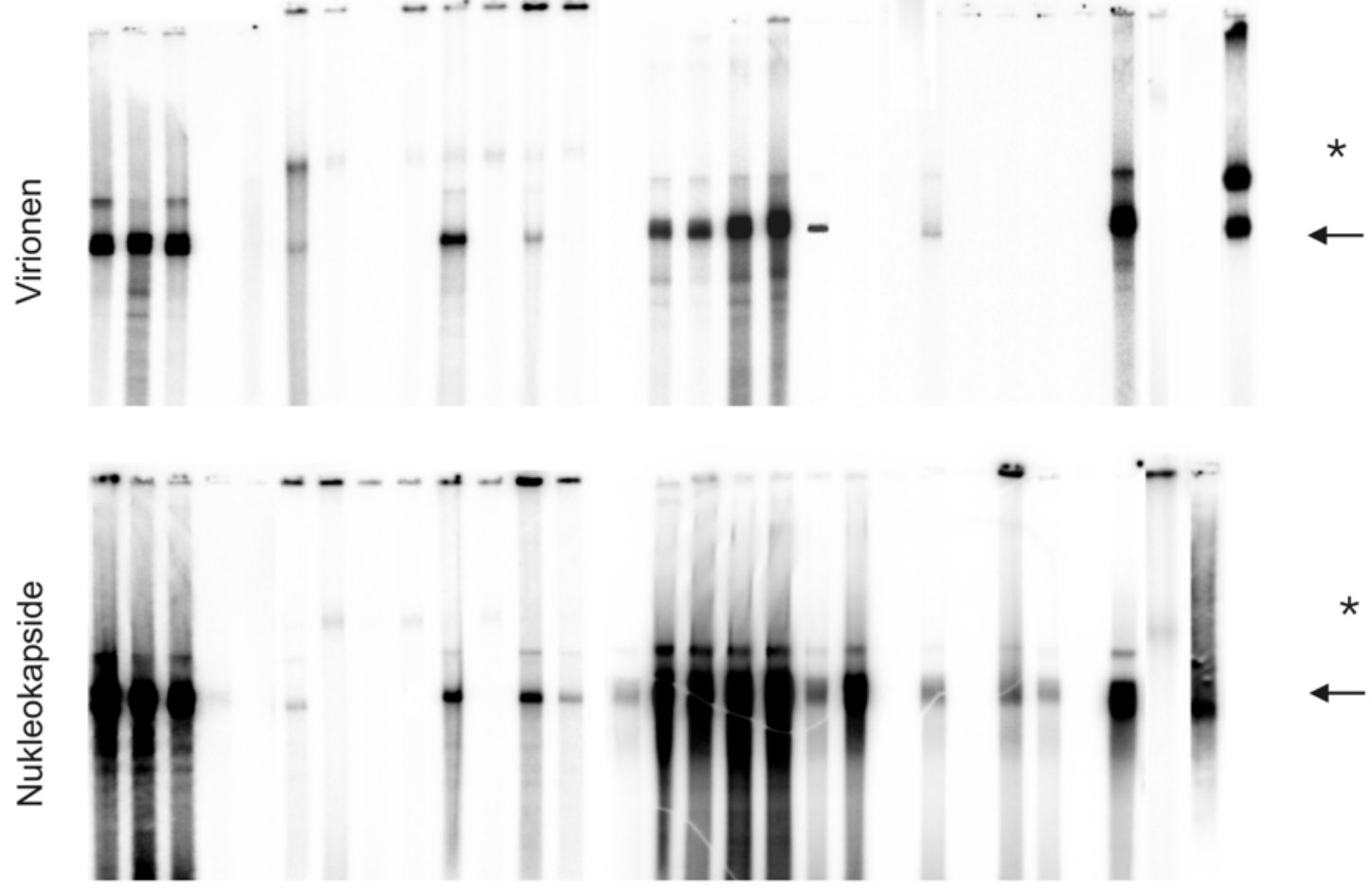


\begin{abstract}
Abb. 16 (vorherige Seite): Repräsentatives Ergebnis der Phänotypisierung von 54 Corepunktmutationen durch den endogenen Polymerase-Nachweis. In der jeweils oberen Spur einer Coremutante ist das Signal der Virionen nach Immunpräzipitation mit $\alpha \mathrm{S}$ aus dem Kulturüberstand aufgetragen. Die mit „Nukleokapside“ bezeichnete untere Spur repräsentiert jeweils das Signal der Nukleokapside nach Immunpräzipitation mit $\alpha \mathrm{C}$ aus den Zelllysaten. Die Pfeile weisen jeweils auf die spezifischen Signale hin. Mit einem Sternchen gekennzeichnete Signale sind als unspezifische Artefakte zu deuten.

$\mathrm{WT}=$ Komplementation des corenegativen HBV-Genoms durch pSVcore; $\mathrm{C}-=$ Ohne Komplementation des corenegativen HBV-Genoms durch pSVcore; LE- = Umhüllungsdefiziente Mutante; serum $=10^{6}$ Virionen aus einem HBV-positiven Patientenserum.
\end{abstract}

Mittels der 3D-Visualisierungssoftware Swiss-PdbViewer konnte nach der phänotypischen Charakterisierung der Coremutanten eine genaue Analyse der Positionen aller Phänotypen zueinander durchgeführt werden. Durch individuelle farbliche Markierung der drei verschiedenen Phänotypen ließen sich die Positionen der einzelnen Phänotypen sowie ihre räumliche Distanzen zueinander genau darstellen.

Abbildung 17 zeigt in drei Teilabbildungen Ansichten eines Coreproteindimers aus einem ca. $45^{\circ}$ Winkel seitlich zum Protein, bei denen jeweils beide Monomere als Kugelmodell dargestellt worden sind. Teilabbildung $\mathrm{c}$ zeigt die Positionen der Phänotypen im Kontext einer Kontaktstelle zweier Dimere. Für alle Abbildungen ist folgender Farbcode verwendet worden: Alle bearbeiteten Aminosäuren sind farbig dargestellt, die nicht mutierten Aminosäuren sind grau. In Grün dargestellte Aminosäuren repräsentieren den Wildtyp-Phänotyp $(\mathrm{K}+\mathrm{V}+)$, und in blauer Farbe sind die Seitenketten dargestellt, deren Alaninsubstitution bewirkte, dass weder Virionen noch Nukleokapside nachweisbar waren $(\mathrm{K}-\mathrm{V}-)$. In Gelb sind die elf Aminosäurepositionen hervorgehoben, die nach Alaninsubstitution zwar noch intrazelluläre Kapside aber keine Umhüllungskompetenz mehr zeigen ( $\mathrm{K}+\mathrm{V}-)$.

Betrachtet man die Abbildung genauer, so kann man zwei Kluster des umhüllungsrelevanten Phänotyps $(\mathrm{K}+\mathrm{V}-)$ erkennen, in denen sich Aminosäuren mit diesem Phänotyp räumlich konzentrieren. Ein Kluster befindet sich auf der C-terminal gelegenen Schleife und betrifft die sechs dort lokalisierten Positionen F122, I126, R127, N136, A137 und I139. Unmittelbar hierzu können zwei weitere Mutanten S17 und F18 mit in dieses Kluster einbezogen werden, die zwar in der Primärsequenz des Proteins weit $a b$, in der Tertiärsequenz jedoch unmittelbar benachbart lokalisiert sind. Ein 

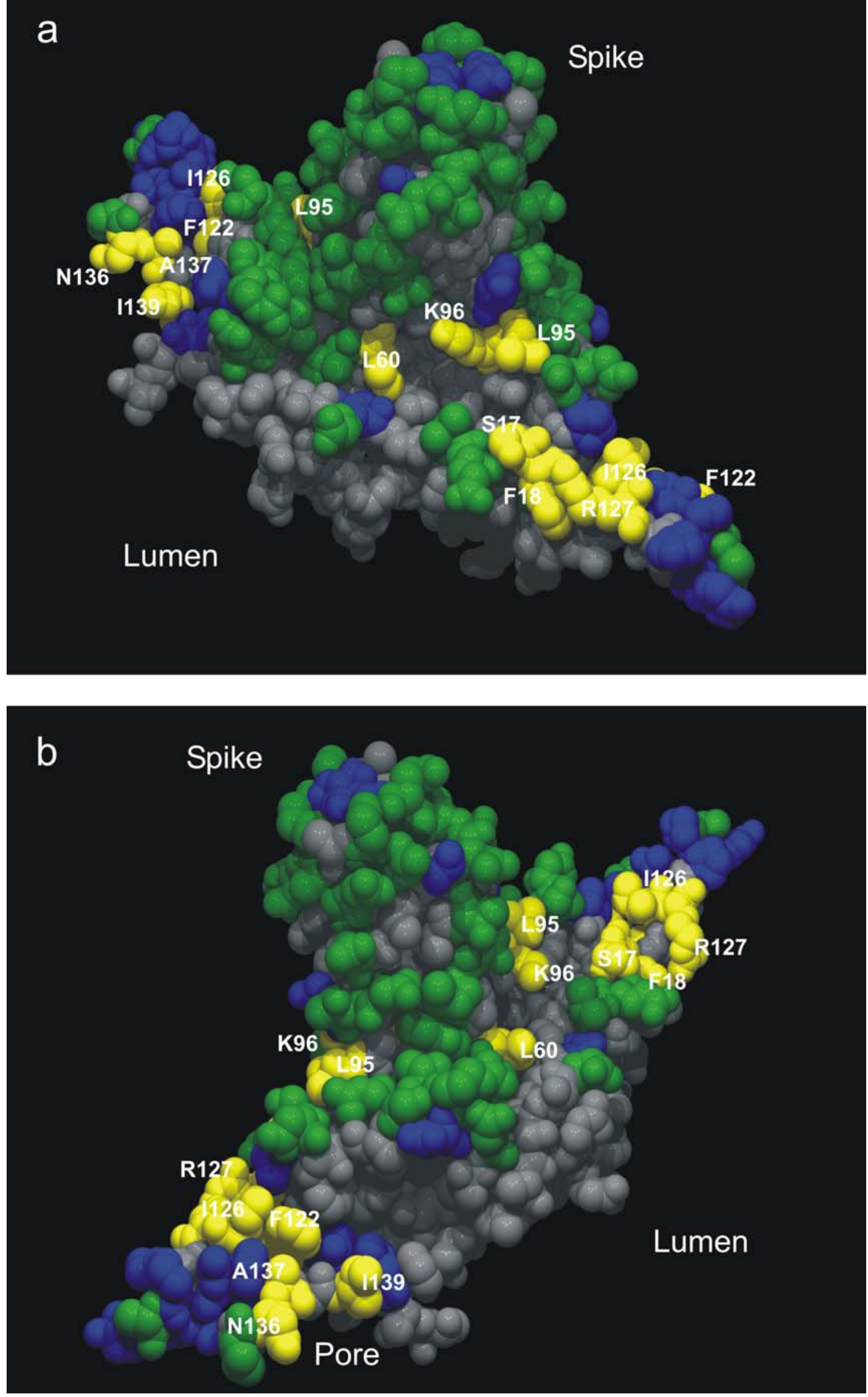


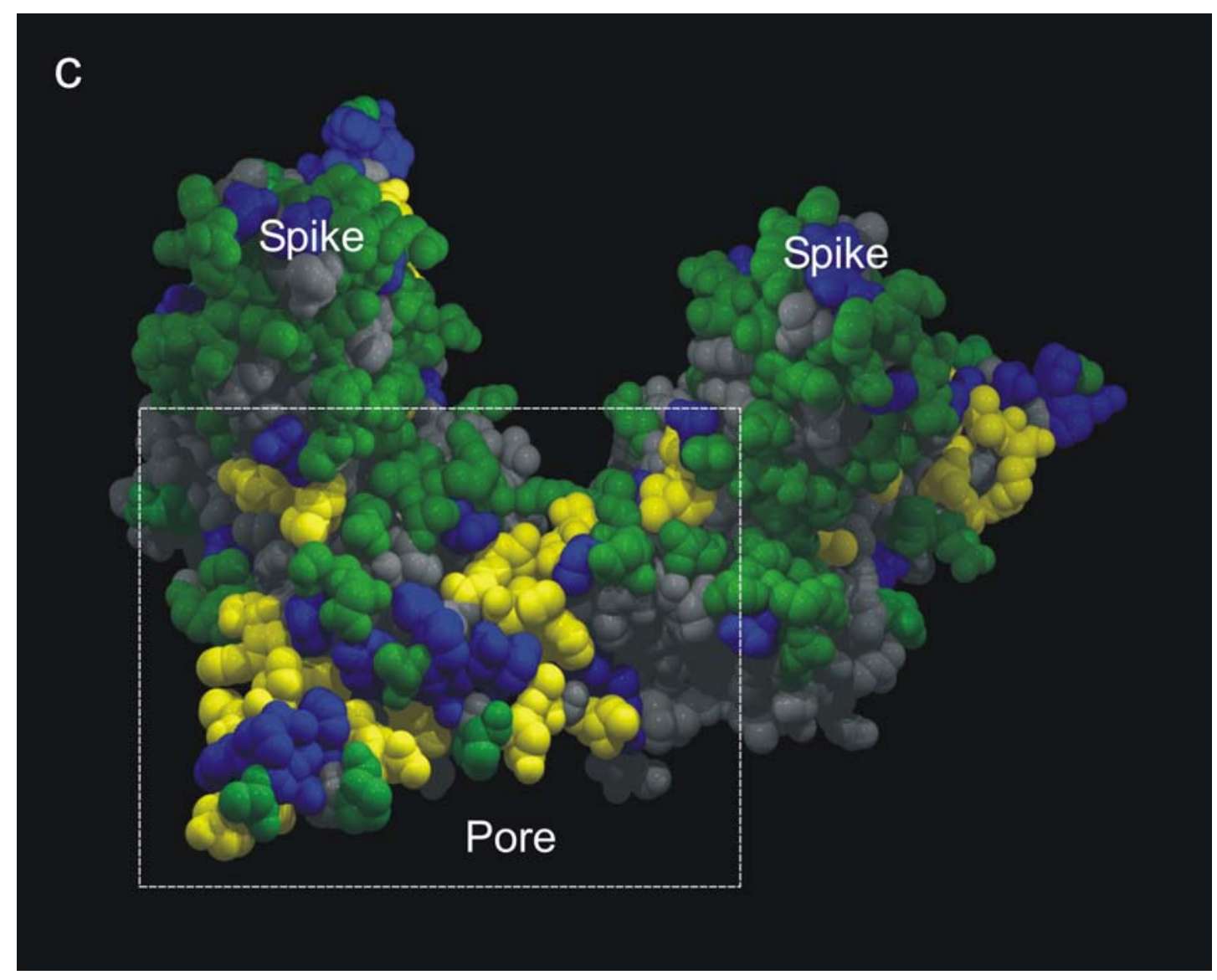

Abb. 17: Lokalisationen der mutierten Aminosäuren und Darstellung des jeweiligen Phänotyps. Die Phänotypen Wildtyp $(\mathrm{K}+\mathrm{V}+)$ sind in Grün, umhüllungsdefizient $(\mathrm{K}+\mathrm{V}-)$ in Gelb und EPR-negativ (K-V-) in Blau angefärbt. Grau angefärbte Aminosäuren wurden nicht bearbeitet.

Die Teilabbildungen $\mathrm{a}$ und $\mathrm{b}$ zeigen jeweils die Vorder- und Rückansicht eines Coreproteindimers. In Weiß nummeriert sind die Positionen der umhüllungsrelevanten Aminosäuren $(\mathrm{K}+\mathrm{V}-)$. Man kann deutlich zwei Kluster vermehrten Auftretens dieses Phänotyps erkennen. Zum einen konzentrieren sich Aminosäuren mit diesem Phänotyp an den C-Termini des Dimers, und zum anderen ist eine ringförmige Anordnung der Aminosäuren L60, L95 und K96 um den Spike herum zu erkennen.

Teilabbildung c zeigt die Lokalisation der umhüllungsrelevanten Stellen im Kontext zweier Coreproteindimere. Im gestrichelten Kästchen ist der Bereich der C-terminalen Kontaktstelle eingegrenzt. Die umhüllungsrelevanten Aminosäuren erscheinen bei dieser Betrachtung im Tal zweier Furchen. Die eine Furche zieht sich über die Kontaktstelle von hinten in Richtung Pore. Der Ring um den Spike bildet ebenfalls eine Furche.

zweites Kluster ist als ringförmige Furche um den Spike zu erkennen und wird durch die im Dimer doppelt auftretenden Aminosäuren L60, L95 und K96 gebildet.

In Teilabbildung $17 \mathrm{c}$ sind die Positionen und Phänotypen im Kontext zweier Dimere dargestellt. Betrachtet man die Kontaktstelle beider Dimere, so erkennt man das C-terminale Kluster am Grund einer Furche, die in Richtung Kapsidpore zieht. 
Tab. 2: Genotyp und Phänotyp der 54 einzelnen Alaninsubstitutionen des HBV-Coregens. $\mathrm{a}=$ Bestimmung des radioaktiven Signals mit einem Röntgenfilm, die Intensität wurde abgeschätzt; $b=$ Angabe nicht sinnvoll.

\begin{tabular}{|c|c|c|c|c|c|c|c|}
\hline \multicolumn{2}{|c|}{ Aminosäure } & \multicolumn{2}{|c|}{ Phänotyp } & \multirow{2}{*}{\multicolumn{2}{|c|}{$\begin{array}{l}\text { Signalintensität } \\
\text { Virionen/Nukleo- } \\
\text { kapside }\end{array}$}} & \multirow{3}{*}{\multicolumn{2}{|c|}{ Position }} \\
\hline & & \multirow{2}{*}{$\begin{array}{l}\text { Nukleo- } \\
\text { kapside }\end{array}$} & \multirow[t]{2}{*}{ Virionen } & & & & \\
\hline & & & & Exp1 & Exp2 & & \\
\hline 2 & $\mathrm{D}$ & + & + & 0,27 & 0,25 & & lateraler \\
\hline 4 & $\mathrm{D}$ & - & - & $-^{b}$ & $-^{b}$ & & basaler \\
\hline 13 & $\mathrm{~V}$ & + & + & 0,35 & 0,26 & $\alpha 1$ & Loop \\
\hline 14 & $\mathrm{E}$ & + & + & $0,3^{a}$ & $1,2^{a}$ & $\alpha 1$ & \\
\hline 17 & $\mathrm{~S}$ & + & - & $<0,02$ & $<0,02$ & $\alpha 1$ & \\
\hline 18 & $\mathrm{~F}$ & + & - & $<0,02$ & $<0,02$ & & \\
\hline 20 & $\mathrm{P}$ & - & - & $-^{b}$ & $-^{b}$ & & \\
\hline 21 & $\mathrm{~S}$ & + & + & $0,6^{a}$ & $1,0^{a}$ & & \\
\hline 22 & $\mathrm{D}$ & + & + & 0,30 & 0,34 & & \\
\hline 26 & $\mathrm{~S}$ & + & + & 0,43 & 0,53 & & \\
\hline 27 & $\mathrm{~V}$ & + & + & $0,3^{a}$ & $1,0^{a}$ & $\alpha 2 \mathrm{a}$ & laterale Helix \\
\hline 28 & $\mathrm{R}$ & + & + & 0,07 & 0,08 & $\alpha 2 a$ & \\
\hline 29 & $\mathrm{D}$ & - & - & & & $\alpha 2 \mathrm{a}$ & \\
\hline 31 & $\mathrm{~L}$ & + & + & 0,14 & 0,33 & $\alpha 2 \mathrm{a}$ & \\
\hline 32 & $\mathrm{D}$ & + & + & 0,24 & 0,25 & $\alpha 2 a$ & \\
\hline 59 & I & + & + & $0,3^{a}$ & $1,0^{a}$ & $\alpha 3$ & Spike \\
\hline 60 & $\mathrm{~L}$ & + & - & $<0,02$ & $<0,02$ & $\alpha 3$ & aufwärts \\
\hline 62 & $\mathrm{~W}$ & + & + & 0,43 & 0,24 & $\alpha 3$ & \\
\hline 66 & $\mathrm{M}$ & + & + & $0,4^{a}$ & $1,2^{a}$ & $\alpha 3$ & \\
\hline 67 & $\mathrm{~T}$ & + & + & 0,61 & 0,55 & $\alpha 3$ & \\
\hline 70 & $\mathrm{~T}$ & + & + & 0,37 & 0,60 & $\alpha 3$ & \\
\hline 73 & G & - & - & $-^{b}$ & $-^{b}$ & $\alpha 3$ & \\
\hline 74 & $\mathrm{~N}$ & + & + & 0,59 & 0,73 & & Spitze des \\
\hline 75 & $\mathrm{~N}$ & + & + & 0,66 & 0,79 & & Spikes \\
\hline 76 & $\mathrm{~L}$ & + & + & 0,64 & 0,82 & & \\
\hline 77 & $\mathrm{E}$ & + & + & 0,55 & 0,79 & & \\
\hline 78 & D & - & - & $-^{b}$ & $-^{b}$ & & \\
\hline
\end{tabular}




\begin{tabular}{|c|c|c|c|c|c|c|c|}
\hline \multirow{3}{*}{\multicolumn{2}{|c|}{ Aminosäure }} & \multicolumn{2}{|c|}{ Phänotyp } & \multirow{2}{*}{\multicolumn{2}{|c|}{$\begin{array}{c}\text { Signalintensität } \\
\text { Virionen/Nukleo- } \\
\text { kapside }\end{array}$}} & \multirow{3}{*}{\multicolumn{2}{|c|}{ Position }} \\
\hline & & \multirow{2}{*}{$\begin{array}{l}\text { Nukleo- } \\
\text { kapside }\end{array}$} & \multirow[t]{2}{*}{ Virionen } & & & & \\
\hline & & & & Exp1 & Exp2 & & \\
\hline 79 & $\mathrm{P}$ & + & + & 0,09 & 0,06 & $\alpha 4 a$ & Spike \\
\hline 82 & $\mathrm{R}$ & + & + & 0,49 & 0,55 & $\alpha 4 a$ & abwärts \\
\hline 83 & $\mathrm{D}$ & + & + & $0,3^{a}$ & $1,5^{a}$ & $\alpha 4 a$ & \\
\hline 84 & $\mathrm{~L}$ & + & + & 0,32 & 0,56 & $\alpha 4 a$ & \\
\hline 87 & $\mathrm{~N}$ & + & + & 0,47 & 0,36 & $\alpha 4 a$ & \\
\hline 90 & $\mathrm{~N}$ & + & + & 0,33 & 0,21 & & \\
\hline 91 & $\mathrm{~T}$ & + & + & 0,15 & 0,46 & & \\
\hline 92 & $\mathrm{~N}$ & - & - & $-^{b}$ & $-^{b}$ & $\alpha 4 b$ & \\
\hline 95 & $\mathrm{~L}$ & + & - & $<0,02$ & $<0,02$ & $\alpha 4 b$ & \\
\hline 96 & $\mathrm{~K}$ & + & - & $<0,02$ & $<0,02$ & $\alpha 4 b$ & \\
\hline 98 & $\mathrm{R}$ & + & + & 0,05 & 0,11 & $\alpha 4 b$ & \\
\hline 118 & $\mathrm{Y}$ & - & - & $-^{b}$ & $-^{b}$ & $\alpha 5$ & vorstehende \\
\hline 119 & $\mathrm{~L}$ & + & + & 0,11 & 0,09 & $\alpha 5$ & Helix \\
\hline 122 & $\mathrm{~F}$ & + & - & $<0,02$ & $<0,02$ & $\alpha 5$ & \\
\hline 125 & $\mathrm{~W}$ & - & - & & & $\alpha 5$ & \\
\hline 126 & I & + & - & $<0,02$ & $<0,02$ & $\alpha 5$ & \\
\hline 127 & $\mathrm{R}$ & + & - & $<0,02$ & $<0,02$ & $\alpha 5$ & \\
\hline 129 & $\mathrm{P}$ & - & - & $-^{b}$ & $-^{b}$ & & Schleife \\
\hline 130 & $\mathrm{P}$ & - & - & $-^{b}$ & $-^{b}$ & & \\
\hline 131 & $\mathrm{~A}$ & + & + & 0,74 & 0,39 & & \\
\hline 132 & $\mathrm{Y}$ & - & - & $-^{b}$ & $-^{b}$ & & \\
\hline 133 & $\mathrm{R}$ & - & - & $-^{b}$ & $-^{b}$ & & \\
\hline 135 & $\mathrm{P}$ & + & + & 0,22 & 0,22 & & \\
\hline 136 & $\mathrm{~N}$ & + & - & $<0,02$ & $<0,02$ & & \\
\hline 137 & A & + & - & $<0,02$ & $<0,02$ & & C-terminale \\
\hline 139 & I & + & - & $<0,02$ & $<0,02$ & & Schleife \\
\hline 140 & $\mathrm{~L}$ & - & - & $-^{b}$ & $-^{b}$ & & \\
\hline WT & & + & + & 0,80 & 0,64 & & \\
\hline
\end{tabular}




\subsubsection{Analyse der Spitze des Spikes - Herstellung und Testung von zwei Dreifachmutanten}

Bei den Alanin-Mutationen an der Spitze des Spikes fällt auf, dass alle den WildtypPhänotyp aufweisen $(\mathrm{K}+\mathrm{V}+)$ mit Ausnahme der Mutante D78, die nicht mehr in der Lage gewesen ist, Nukleokapside zu bilden (K-V-) (siehe Abb. 18). Im Widerspruch zu diesem Ergebnis zeigten in vitro Bindungsversuche, dass kurze aus den Hüllproteinen sich ableitende Peptide an der Spitze des Spikes binden (BÖTTCHER et al., 1998) und die Umhüllung verhindern (DYSON und MURAY, 1995). Aus diesen Experimenten war geschlossen worden, dass die Spitze des Spikes an der Umhüllung beteiligt ist.

Da es möglich erscheint, dass einzelne Punktmutationen in dieser Region keinen Defekt erzeugen, wurden zwei nachfolgend beschriebene Dreifachmutanten hergestellt, die auf den Ergebnissen der einzelnen Punktmutationenanalysen (Abschnitt 4.1.3) basieren. Beide Mutanten trugen dreifache Alaninsubstitutionen an den Stellen N74-N75-E77 bzw. N74-E77-P79. In den Versuchen zuvor zeigten die Positionen bereits als einzelne Alaninsubstitutionen einen Wildtyp-Phänotyp $(\mathrm{K}+\mathrm{V}+)$. Es sollte nunmehr getestet werden, wie sich beide Dreifachmutanten hinsichtlich ihrer Umhüllungskompetenz verhalten.

Die Herstellung der Mutanten erfolgte in vitro durch PCR wie bereits beschrieben (4.1.2). Beide Mutanten wurden nach Herstellung und Überprüfung durch Sequenzierung (3.1.5) im zuvor verwendeten Expressionssystem (pSVHBV1.5core ${ }^{-}$ komplementiert durch pSVcore) in Zellkultur exprimiert. Anschließend wurden sie hinsichtlich ihrer Umhüllungskompetenz durch einen EPR-Nachweis nach Immunpräzipitation von Virionen aus den Zellkulturüberständen und Nukleokapsiden aus den Zelllysaten untersucht.

Abb. 19 zeigt die Ergebnisse der Autoradiogramme. Als Kontrolle diente wiederum eine Transfektion mit dem Plasmid pSVHBV1.5core ${ }^{-}$(Spur $\mathrm{C}^{-}$), die durch pSVcore erfolgreich komplementiert werden konnte (Spur WT). Eine Transfektion mit der umhüllungsdefizienten Mutante pSVHBV1.5 LE ${ }^{-}$zeigte erwartungsgemäß kein Signal im Zellkulturüberstand. Wie deutlich zu erkennen ist, waren beide Dreifachmutanten 
(Spur NNE für N74-N75-E77 und Spur NEP für N74-E77-P79) in der Lage, Virionen im Zellkulturüberstand zu bilden.

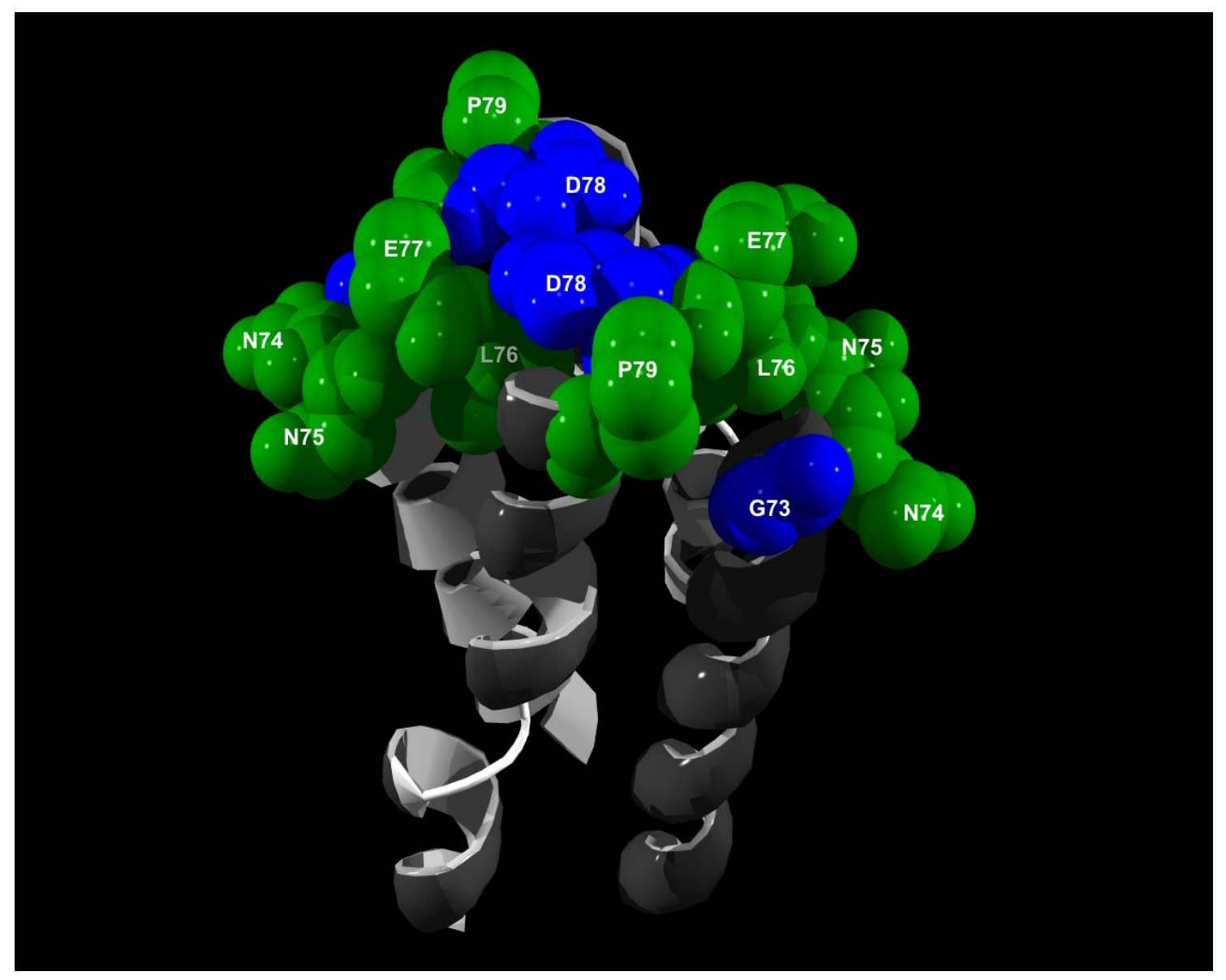

Abb. 18: Graphische Darstellung der Spitze des Spikes eines Coreproteindimers. Es sind jeweils die Aminosäuren G73, N74, N75, L76, E77, D78 und P79 als Kugelmodell in dem zuvor bereits verwendeten Farbcode dargestellt. Die Aufnahme wurde aus einem ca. $60^{\circ}$ Blickwinkel über der seitlichen Spitze des Spikes gemacht. Alaninaustausche der Positionen N74, N75, L76, E77 und P79 führen sowohl als einzelne Mutationen als auch als Dreifachmutationen in den Kombinationen N74-N75-E77 und N75-E77-P79 beim Test auf Umhüllungskompetenz zum Wildtyp-Phänotyp. Sie decken die gesamte Oberfläche der Spitze des Spikes ab. 

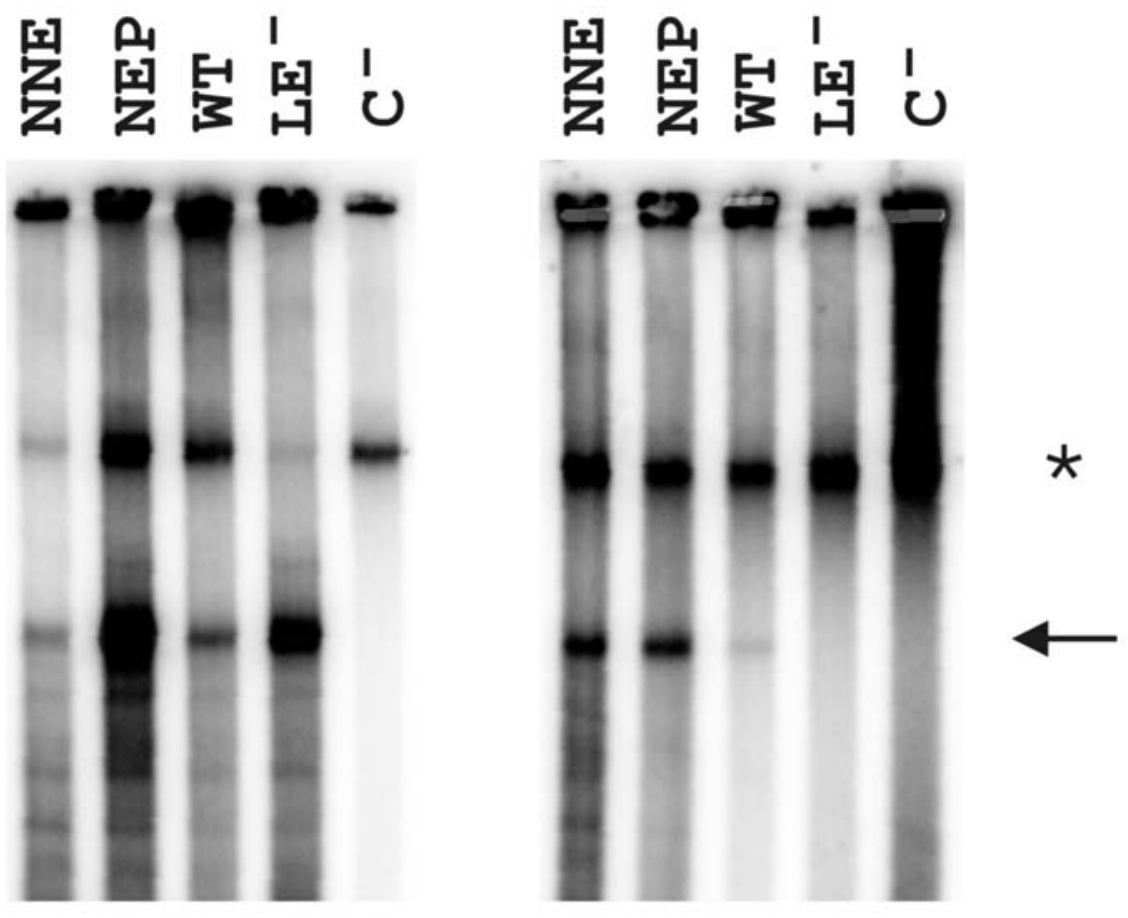

\title{
Nukleokapside
}

\section{Virionen}

\begin{abstract}
Abb. 19: Repräsentatives Ergebnis der Phänotypisierung der beiden Dreifachmutanten N74-N75-E77 (NNE) und N75-E77-P79 (NEP) durch den EPR-Nachweis nach Immunpräzipitation von Nukleokapsiden aus Zelllysaten (linke Teilabbildung) und Virionen aus Zellkulturüberständen (rechte Teilabbildung). Beide Dreifachmutanten sind in der Lage, sowohl Nukleokapside als auch Virionen zu bilden.

Die Pfeile weisen jeweils auf spezifische Signale. Mit einem Sternchen gekennzeichnete Signale sind unspezifische Artefakte.

$\mathrm{WT}=$ Komplementation des corenegativen HBV-Genoms durch pSVcore; $\mathrm{C}^{-}=$Ohne Komplementation des corenegativen HBV-Genoms durch pSVcore; LE ${ }^{-}=$Umhüllungsdefiziente Mutante.
\end{abstract}




\subsubsection{Untersuchung der EPR-negativen Coremutanten}

Alle in dieser Arbeit hergestellten Coremutanten tragen eine Mutation pro Monomer auf der Oberfläche des Kapsids. Bei einem T $=4$ symmetrischen HBV-Kapsid, welches aus 120 Coreproteindimeren zusammengesetzt ist, vervielfältigt sich dieser Wert auf insgesamt 240 Mutationen pro Kapsid.

Eines der ersten Stadien der Nukleokapsidbildung stellt die Assemblierung des Kapsids zum Homomultimer dar. Die Assemblierung findet spontan nach Bindung der viralen Polymerase und deren Verpackung aus zuvor gebildeten Coreproteindimerbausteinen statt (ZHOU und STANDERING, 1992). Es ist naheliegend, dass bereits die Assemblierung des Kapsids durch das Einfügen von nur einer Mutation erheblich gestört werden könnte.

Aber auch andere Defekte während der Morphogenese des Nukleokapsids sind denkbar. Wichtige Punkte sind vor allem die Verpackung der prägenomischen RNA, die aufwändige reverse Transkription des Prägenoms im Inneren des Kapsids und die Generierung eines strukturellen Reifungssignals, welches die Kompetenz zur Umhüllung verleiht. An allen Prozessen ist das Kapsid direkt oder indirekt beteiligt. Vor allem dem argininreichen C-Terminus des Coreproteins wird eine hohe Affinität zu viralen Nukleinsäuren zugeschrieben. So könnten auch indirekt Mutationen, die zu konformationellen Änderungen in der Struktur der Kapsidhülle und vor allem der räumlichen Anordnung funktioneller Seitengruppen führen, die Reifung des Nukleokapsids beeinträchtigen.

In den nachfolgenden Experimenten sollte versucht werden, die Mutanten, die keine mit der EPR detektierbaren Kapside bilden (K-V-) näher zu charakterisieren. Die Versuche basierten hierbei auf dem Nachweis einzelner Stadien des Kapsids, die es während der Bildung durchläuft. Es wurden zunächst der Nachweis assemblierter Kapside durch Western-Blot-Analyse nach PEG-Fällung als frühestes Stadium der Kapsidmorphogenese sowie Southern-Blot-Analyse nach Immunpräzipitation als Nachweis eines späten Stadiums durchgeführt. Für Mutanten, die zwar Kapside assemblieren können, jedoch keine DNA-haltigen Nukleokapside mehr nachweisen, waren weitere Versuche wie der Nachweis des verpackten RNA-Prägenoms geplant. 
Die folgenden beiden Versuche, Western-Blot-Analyse nach PEG-Fällung (4.1.5.1) und Southern-Blot-Analyse nach Immunpräzipitation von Nukleokapsiden (4.1.5.2) wurden parallel nach Ernte eines Transfektionsansatzes durchgeführt, um den Nachweis beider Stadien direkter vergleichen zu können.

\subsubsection{Nachweis assemblierter Kapside durch PEG-Fällung und anschließendem nativen Western-Blot}

Eine Möglichkeit des Nachweises assemblierter Kapside ist der native Western-Blot nach Fällung assemblierter Kapside aus dem Zelllysat durch PEG 8000 und Agarosegelelektrophorese .

Jeweils zwei Schalen HuH7-Zellen wurden mit den 13 EPR-negativen Coremutanten D4, P20, D29, G73, D78, N92, Y118, P129, P130, Y132, R133, L140 und W125 sowie jeweils mit pSVHBV1.5 core $^{-}$kotransfiziert. Drei Tage nach Transfektion wurden die Zellen geerntet und Zelllysate hergestellt (3.3.6). Die Zelllysate von zwei Schalen wurden vereinigt und dienten als Ausgangsmaterial für diesen und den nächsten Versuch (4.1.5.2). Eine Hälfte der Zelllysate wurde mit $10 \%$ (w/v) PEG 8000 und $2 \%(\mathrm{w} / \mathrm{v}) \mathrm{NaCl}$ versetzt und über $\mathrm{Nacht}$ bei $4^{\circ} \mathrm{C}$ gefällt. Nach Isolierung der Präzipitate wurden diese durch ein Agarosegel elektrophoretisiert (3.1.4.6) und auf eine Nitrozellulosemembran geblottet (3.1.8.5). Der Nachweis der geblotteten Kapside erfolgte anschließend mit einem polyklonalen anti-HBc-Kaninchenserum sowie einem anti-Kaninchen-IgG-Peroxydasekonjugat (3.1.8.6).

Abbildung 20 zeigt exemplarisch ein Ergebnis eines Immunblots nach Detektion des Konjugats durch das Chemilumineszens-System ECL. Die stärksten Signale wurden durch die drei Aspartat-zu-Alanin-Austausche D78, D29 und D4 generiert, wobei auch deutlich zu erkennen ist, dass vor allem die Mutanten D78 und D29 im Gel langsamer liefen als vergleichsweise Wildtyp-Kapside. P20, P129 und Y132 zeigten deutlich 

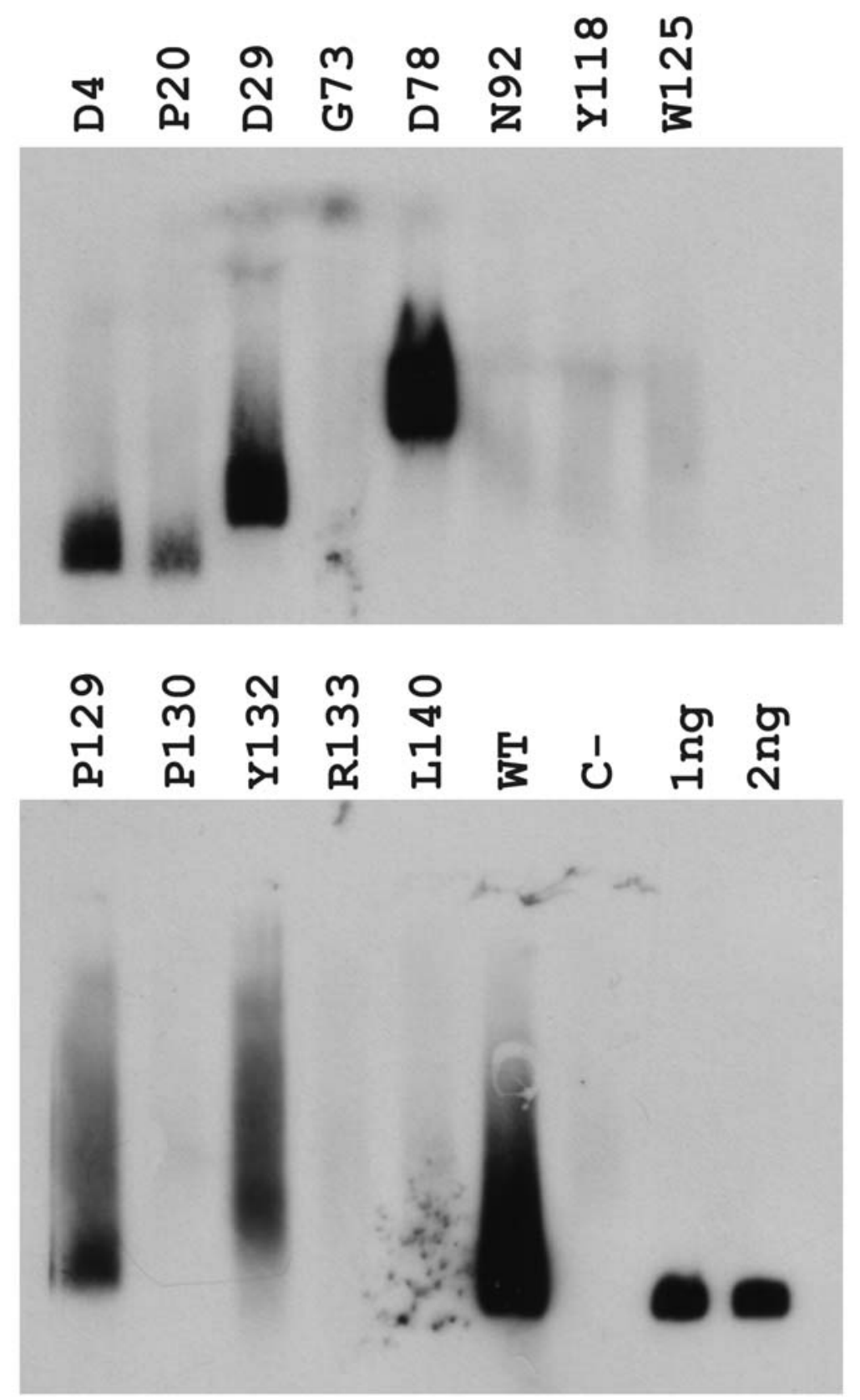

Abb. 20: Nachweis assemblierter Kapside durch Western-Blot nach PEG-Fällung. HuH7Zellen wurden mit EPR-negativen Coremutanten D4, P20, D29, G73, D78, N92, Y118,

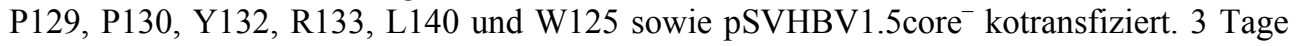
nach Transfektion wurden die Zelllysate hergestellt und cytosolische Kapside durch PEG 8000 gefällt. Die präzipitierten Kapside wurden nativ auf Nitrozellulose geblottet und im Immunblot nachgewiesen. Die Mutanten D78, D29, D4 zeigen die stärksten Signale. 
schwächere, aber dennoch klar detektierbare Signale. G73, N92, Y118, W125, P130, R133 und L140 zeigten keine Signale mehr. Als Positivkontrollen wurden 1 ng und 2 ng von in E. coli rekombinant hergestelltem aufgereinigten Coreprotein aufgetragen. Anhand der Bandenstärken der Kontrollen ließ sich abschätzen, dass bei den Coremutanten zwischen $0,1 \mathrm{ng}$ und etwa $5 \mathrm{ng}$ Coreprotein aufgetragen worden war.

\subsubsection{Nachweis DNA-enthaltender Nukleokapside durch Southern-Blot nach Immunpräzipitation}

Ein spezifischer Nachweis DNA-haltiger Kapside beruht auf Southern-Blot-Analyse immunpräzipitierter HBV-Kapside aus Zelllysaten transfizierter Zellen. Anders als beim EPR-Nachweis (3.1.6.2) trifft dieser Test eine Aussage über die Reife der Nukleokapside. Während in der EPR der Nachweis über den Einbau radioaktiv markierter Nukleotide in das partiell doppelsträngige DNA-Genom verläuft, findet bei dieser Methode ein genereller Nachweis jeglicher HBV-DNA aus Nukleokapsiden statt. Jeweils zwei Schalen HuH7-Zellen wurden mit den EPR-negativen Coremutanten D4, P20, D29, G73, D78, N92, Y118, P129, P130, Y132, R133, L140 und W125 sowie jeweils mit pSVHBV1.5 core $^{-}$kotransfiziert. Drei Tage nach Transfektion wurden die Zellen geerntet und Zelllysate hergestellt (3.3.6). Die Zelllysate der jeweils zwei parallel transfizierten Ansätze wurden vereinigt und dienten als Ausgangsmaterial für diesen und den vorhergehenden Versuch (4.1.5.1). Die Hälfte der Zelllysate wurden über Nacht mit einem an Protein-A-Sepharose gekoppelten polyklonalen anti-HBcAntikörper immunpräzipitiert (3.1.8.1). Am nächsten Tag wurde die DNA der Immunpräzipitate aufgereinigt (3.1.6.3) auf einem Agarosegel aufgetragen (3.1.6.1) und mittels Kapillarblot auf eine Nylonmembran transferiert. Der Nachweis der isolierten HBV-DNA erfolgte durch eine an alkalischer Phosphatase gekoppelten HBV-Sonde.

In Abbildung 21 sind die Signale nach Southern-Blot-Analyse dargestellt. Schwache Signale sind lediglich bei den Mutanten D4, D29 und D78 zu erkennen. 


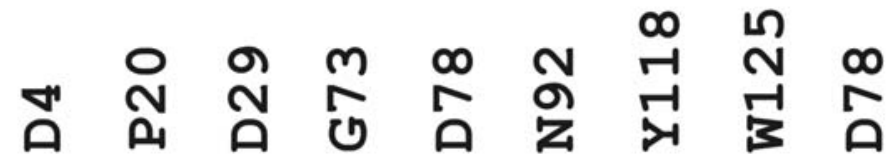

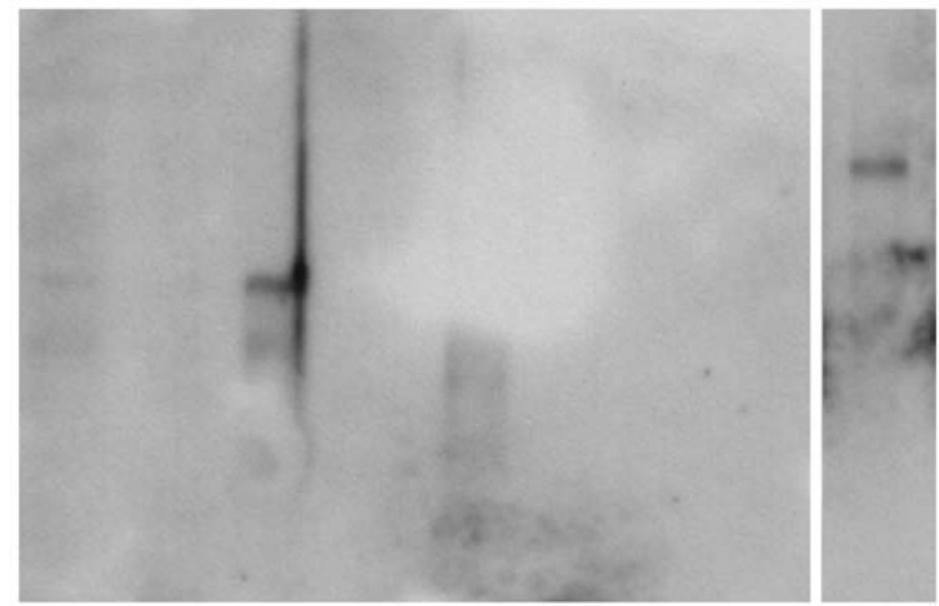

\section{$3,2 \mathrm{~kb}$}

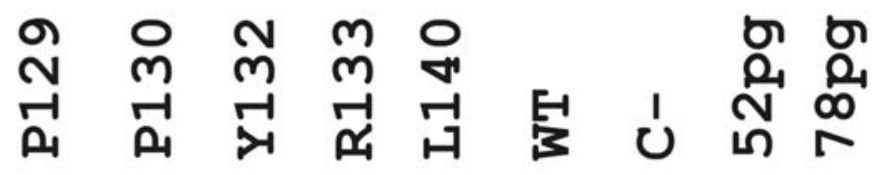

\section{$3,2 \mathrm{~kb}$}

Abb. 21.: Nachweis DNA-haltiger Nukleokapside durch Immunpräzipitation und SouthernBlot. HuH7-Zellen wurden mit EPR-negativen Coremutanten D4, P20, D29, G73, D78, N92, Y118, P129, P130, Y132, R133, L140 und W125 sowie pSVHBV1.5 core $^{-}$ kotransfiziert. 3 Tage nach Transfektion wurden die Zelllysate hergestellt und Nukleokapside mit Protein-A-Sepharose gekoppeltem anti-HBc-Antikörper immunpräzipitiert. Die DNA der Immunpräzipitate wurde aufgereinigt, auf Nitrozellulose geblottet und mit einer peroxydasegekoppelten HBV-Sonde im Southern-Blot nachgewiesen. Lediglich die Mutanten D78, D29, D4 zeigen schwache Signale im Bereich von 10 bis 150 pg DNA, verglichen mit den Positivkontrollen. 


\subsection{Klonierung und Oberflächenpräsentation des monoklonalen Antikörpers MA18/7}

Alle Viren der Familie Hepadnaviridae besitzen eine hohe Spezies- und Wirtszellspezifität. Neben der natürlichen Infektion der Leber ist das menschliche HBV in der Lage, primäre Hepatozytenkulturen des Menschen und einigen humanoiden Primaten, wie z.B. den Schimpansen, zu infizieren (Acs et al. 1987). Die Infizierbarkeit dieser Zellen verliert sich allerdings wenige Tage nach Inkulturnahme der Zellen (TUTTLEMAN et al., 1986). Es wird vermutet, dass die Zellen das Protein verlieren, welches dem Virus als Rezeptor dient. Menschliche Hepatoblastomzelllinien, wie HepG2- oder HuH7Zellen, die aufgrund ihrer einfachen Kultivierung überwiegend in der Erforschung zellulärer Prozesse der HBV-Morphogenese verwendet werden, lassen sich nicht mehr mit dem Virus infizieren. Der größte Anteil der bisher veröffentlichten Arbeiten zur Biologie des HBV basiert auf Techniken der Transfektion und Transduktion von VirusDNA enthaltenden Vektoren. Diese Techniken sind jedoch meist so effizient, dass aufgrund der großen Menge der eingebrachten Virus-DNA nach kurzer Zeit die Produktion von HBV-Virionen beginnt. Das Studium der frühen Stadien der HBVMorphogenese, die in Abhängigkeit von einer geringen Anzahl nukleärer HBVGenomkopien steht, würde jedoch eine Methode erfordern, die es erlaubt, solch einfach zu kultivierende Zellkulturen effizient zu infizieren oder in einem infektionsähnlichen Prozess mit wenigen Virionen zu transfizieren.

Neben der Produktion von Virionen durch Umhüllung des reifen Nukleokapsids am ER kann das reife Nukleokapsid auch zum Zellkern rekrutiert werden, wo es den Gehalt an viralen Genomen erhöht. Aufgrund einer Halbwertszeit der ccc-DNA von 30 bis 50 Tagen (ADDISON et al., 2002) muss dieser Prozess während der gesamten Infektion einer Zelle stattfinden, vor allem aber in der frühen Phase, wenn nur sehr wenige Genomkopien im Zellkern vorliegen. Das Nukleokapsid tritt hierbei in Kontakt mit Komponenten der Kernpore, kann sie passieren (PANTÉ und KANN, 2002) und bleibt im nuclear basket hängen. Nur reife Nukleokapside sind dann in der Lage zu disassemblieren und entlassen Genom und Coreproteine in das Karyoplasma (PANTÉ und KANN, 2002). Voraussetzung für diesen Prozess wird ähnlich wie bei der Umhüllungsreaktion eine Protein-Proteininteraktion zwischen der Kapsidoberfläche und 
Komponenten des Kerntransports bzw. der Kernpore sein. Für eine Untersuchung dieser Interaktion würden sich die bereits hergestellten Coremutanten bestens eignen, da sie mit der Fragestellung einer von außen stattfindenden Protein-Proteininteraktion ausgewählt wurden.

Somit war ein weiteres Ziel dieser Arbeit, ein Infektionsmodell zu etablieren, welches erlaubt, in den etablierten Zellkultursystemen die frühe Phase der Virusmorphogenese zu untersuchen. So könnten später die in dieser Arbeit bereits beschriebenen Coremutanten auch zur Charakterisierung der frühen Funktionen des Nukleokapsids, z.B. beim Zellkerntransport, herangezogen werden.

Grundidee dieses Projekts war die Generierung eines künstlichen HBV-Rezeptors zur Herstellung einer infizierbaren Leberzellkultur, wie HepG2 oder HuH7. Der monoklonale Antikörper MA18/7, der gegen das große Hüllprotein gerichtet ist, sollte aus einer Hybridomzelllinie kloniert und rekombinant exprimiert werden. Durch C-terminale Fusion einer geeigneten Transmembrandomäne sollte eine Oberflächenpräsentation dieses Antikörpers erreicht werden, so dass nach Expression in HuH7- oder HepG2-Zellen Virionen auf der Zellmembran binden können. Möglicherweise könnte schon die Bindung von Virionen auf der Zelloberfläche die Infizierbarkeit der Zellen wiederherstellen.

\subsubsection{Klonierung des monoklonalen Antikörpers MA18/7}

Der monoklonale Antikörper MA18/7 wird von einer Maus-Hybridomzelllinie exprimiert, die 1984 von der Arbeitsgruppe Gerlich durch eine Immunisierung von fünf Mäusen mit HBV-Partikeln hergestellt wurde (HEERMAN et al., 1984). Der Antikörper wird der Klasse der $\operatorname{IgG}_{1}$-Kappa zugeordnet. Die Spezifität ist auf das N-terminale DPAF-Epitop (AS 31 - 34) im präS1-Bereich des großen Hüllproteins des HBV gerichtet (SOMINSKAYA et al., 1992).

Die Klonierung des Antikörpers sollte durch reverse Transkription zellulärer mRNA erfolgen. Hierfür wurde die Hybridomzelllinie in Kultur genommen und mittels Oligotex-direct-mRNA-Kit (Qiagen, Hilden) zelluläre mRNA isoliert (3.1.10). Diese 
diente anschließend als Template für eine reverse Transkription (RT) zur Herstellung der cDNAs. Zur spezifischen Isolierung der mRNA für die leichte und schwere Kette von MA18/7 aus dem Gesamtpool zellulärer mRNAs wurde ein degeneriertes Primerset verwendet, das eigens zur Isolierung solcher Antikörper mittels RT-PCR entwickelt wurde (freundlich zur Verfügung gestellt von Christoph Dietrich, Abt. Immunologie, Universität Göttingen). Insgesamt 14 Oligonukleotide für die schwere und 15 Oligonukleotide für die leichte Kette trugen Konsensussequenzen der 5'-lokalisierten Signalpeptide aus einer Datenbank für $\mathrm{IgG}_{1}$-Antikörper und wurden zur cDNASynthese eingesetzt. Da zelluläre mRNAs polyadenyliert werden, konnte als 3'-Oligonukleotid für die nachfolgende PCR ein unspezifisches oligo-dT-Nukleotid verwendet werden. Die nach der cDNA-Synthese folgende PCR-Amplifikation wurde in einem Schritt mit dem ONE STEP RT-PCR-Kit (Gibco BRL, Eggenstein) durchgeführt (3.1.11). Die erhaltenen PCR-Produkte wurden anschließend auf einem $1 \%$ analytischen Agarosegel aufgetrennt und ihrer Größe nach beurteilt.

In Abbildung 22 ist das Ergebnis einer RT-PCR dargestellt. Für die schwere Kette wurde ein Produkt von etwa 1000 bp erwartet, die leichte Kette sollte ca. 700 bp lang sein. Die PCR-Produkte der 5'-Oligonukleotide HC4a, HC5a und HC9 der schweren Kette sowie LC4, LC6, LC8b, LC8d, LC8e und LC10 der leichten Kette wiesen die erwarteten Größen auf. Sie wurden daraufhin direkt in den pCR2.1-Vektor kloniert (3.1.7) und sequenziert (3.1.5). Für die leichte Kette ergaben die Sequenzen der Klone LC6 und LC8d eine Übereinstimmung mit der in der NCBI-Datenbank registrierten cDNA-Sequenzen leichter Ketten verschiedenster Antikörper aus der Maus. Hier stellte sich allerdings später heraus, dass der Klon LC6 eine aberrante Kette repräsentierte, die an Position 105 ein Stopkodon trägt (CARROLL et al., 1988), woraufhin der Klon verworfen wurde. Die aberrante Kette wird von der für die Herstellung der Hybridomzelllinie genutzten Zelllinie P3-X63-Ag8.653 exprimiert. Für die weiteren Versuche kam der Klon LC8d als leichte Kette zum Einsatz. Die Sequenz stimmte mit der publizierten variablen Region des MA18/7-Antikörpers überein (NCBI-Datenbank Nr. AJ002099). Bei den drei Kandidaten für die schwere Kette zeigte lediglich der Klon HC9 eine Übereinstimmung mit Antikörpersequenzen aus der Maus und der variablen Region von MA18/7 (NCBI-Datenbank Nr. AJ002098). 


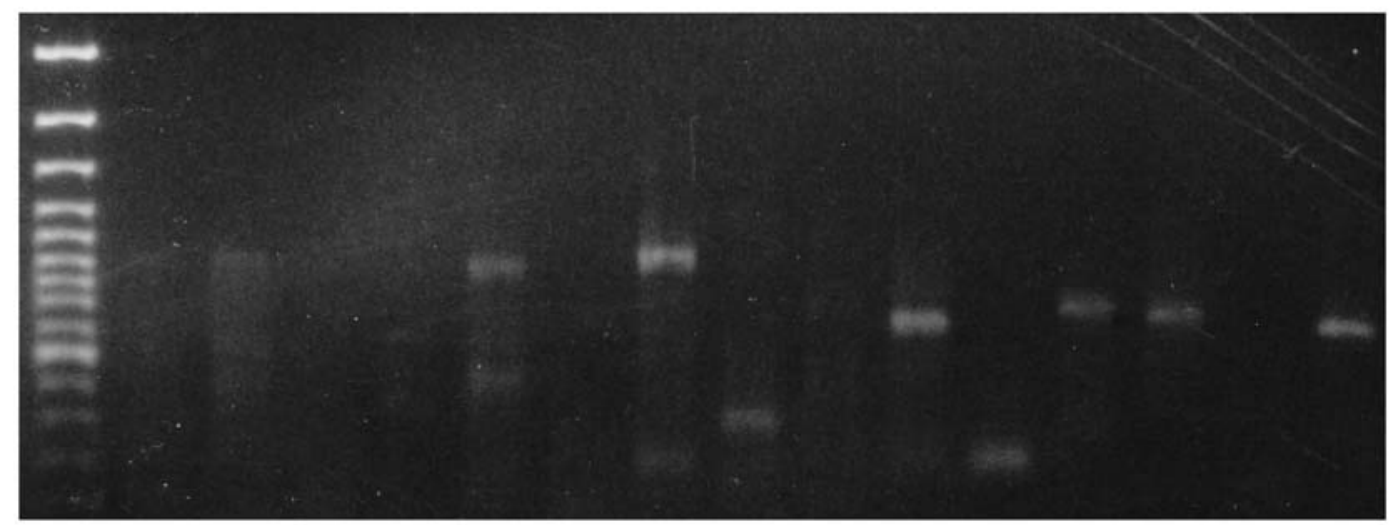

\section{离}
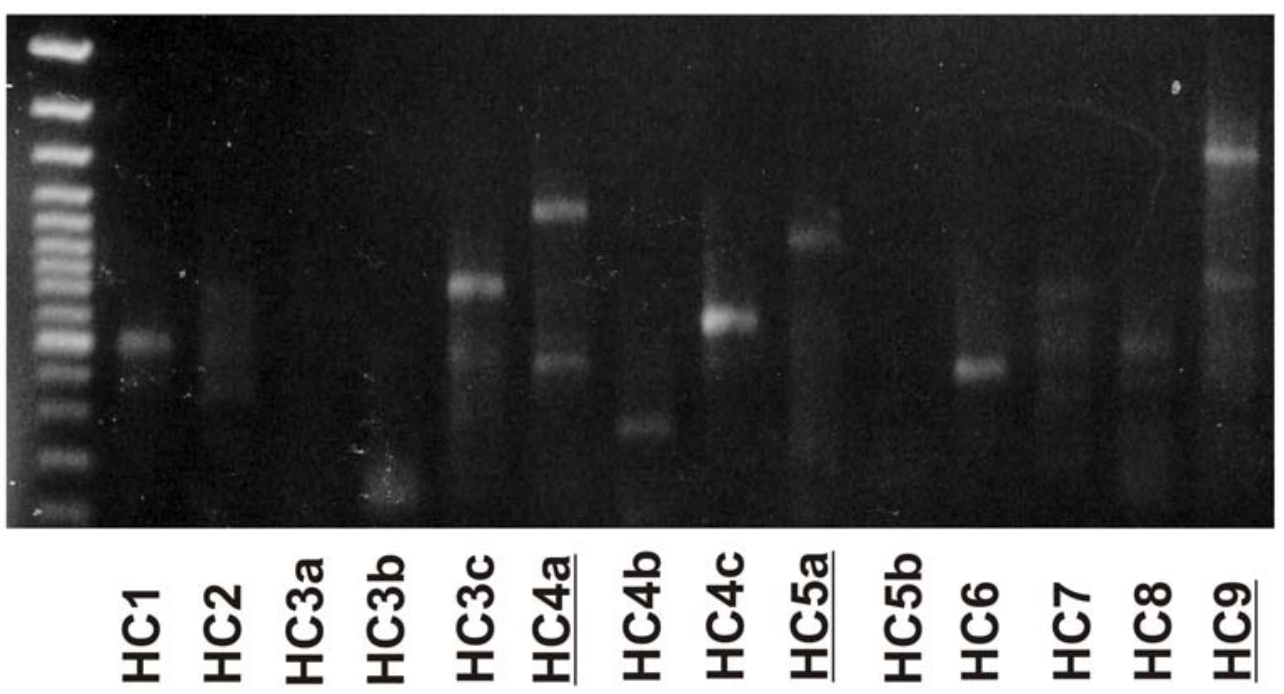

Abb. 22: Darstellung der Amplifikationsprodukte nach cDNA-Synthese und PCR. Mit LC wurden die Produkte beschriftet, die mit den degenerierten Primern für die leichte Kette amplifiziert wurden, mit HC die für die schwere Kette. Die Produkte LC4, LC6, LC8b, LC8d, LC8e und LC10, sowie HC4a, HC5a und HC9 wurden anschließend in einen PCR2.1-Vektor kloniert und sequenziert. LC8d und HC9 zeigten nach Vergleich mit Sequenzen der Genbank NCBI die identischen Sequenzen und wurden für die weiteren Versuche verwendet. 


\subsubsection{Herstellung des Rezeptorimitats}

Durch die für die cDNA-Synthese eingesetzten degenerierten Oligonukleotide, die mit der Sequenz des Signalpeptids auf der mRNA hybridisierten, kam es bei beiden Ketten zum Verlust der ersten Nukleotide. Durch Datenbankabgleiche konnte der Aminosäurecode der 5'-gelegenen fehlenden Sequenzen identifiziert werden. Für die schwere Kette fehlten die Nukleotide für die Aminosäuren MRVLILLWLFT, in der leichten Kette fehlte die DNA-Sequenz für MESQTLVFISI. Durch Einsatz von Oligonukleotiden wurden die fehlenden Nukleotide in einer PCR wieder hergestellt sowie eine Kozak-Sequenz (ACC ATG) als Startkodon an beide Ketten 5' anfusioniert (KOZAK, 1986).

Für die schwere Kette waren zwei Varianten geplant: Eine Variante sollte mit einer Transmembrandomäne versehen und somit oberflächenexponiert werden. Eine zweite Variante sollte für Kontrollversuche als sekretorische Variante fungieren. Die Immunglobuline (Ig) aller fünf Isotypen können durch alternatives Splicen als sekretorischer Antikörper oder als membranständiger B-Zell-Antigenrezeptor exprimiert werden (WALL und KUEHL, 1983). Als bester Kandidat für eine Transmembrandomäne erwies sich $\operatorname{IgD}$, da sich die membrangebundenen Formen der IgDs als einzige ohne weitere Kofaktoren zelloberflächenpräsentieren lassen (WIENANDS und RETH, 1992). Für die Klonierung der IgD-Transmembrandomäne konnten anhand der Sequenzveröffentlichungen der NCBI-Datenbank Oligonukleotide erstellt werden. Das 5'-Oligonukleotid wurde mit einem Überlappungsbereich zur bereits klonierten schweren Kette des MA18/7-Antikörpers IgGHC9 versehen, so dass die Transmembrandomäne durch eine weitere PCR an die schwere Kette fusioniert werden konnte. Das Polyadenylierungssignal wurde vom Expressionsplasmid zur Verfügung gestellt.

Die nachfolgend beschriebenen Klonierungsschritte sind in Abb. 23 dargestellt. In einem ersten Schritt wurden durch PCR die 5' fehlenden Nukleotide sowie die KozakSequenz an die schwere Kette HC9 anfusioniert. Als Template diente der Vektor pCR2.1HC9. Das 5'-Oligonukleotid \#0169 enthielt die Kozak-Sequenz und 33 Nukleotide, die für die N-terminal fehlenden Aminosäuren MRVLILLWLFT des Signalpeptids codieren sowie einen Hybridisierungsbereich mit HC9 von 
15 Nukleotiden. Das 3'-Oligonukleotid \#0170 wurde so gewählt, dass das terminale Lysin und das Stopkodon, welches beim alternativen Splicen eliminiert wird, nicht mitamplifiziert wurde. Das $1371 \mathrm{bp}$ große PCR-Produkt wurde anschließend direkt zur Fusion der IgD-Transmembrandomäne eingesetzt.

Als Template zur Amplifikation der IgD-Transmembrandomäne (IgDTM) diente chromosomale DNA aus Mausfibroblasten. Die Zellen wurden für 5 Minuten bei $96{ }^{\circ} \mathrm{C}$ inkubiert und direkt für eine Standard-PCR mit den Oligonukleotiden \#0171 und \#0172 eingesetzt. Oligonukleotid \#0171 bestand aus 27 Nukleotiden der 3'-Sequenz aus HC9 und 18 Nukleotiden der 3'-Sequenz aus IgDTM. Das erhaltene 200 bp große Produkt der Transmembrandomäne IgD wurde anschließend in einer zweiten PCR an das 3'-Ende der schweren Kette HC9 fusioniert. Für die Fusion der schweren Kette mit der Transmembrandomäne wurden in einer finalen PCR zunächst beide Produkte ohne Oligonukleotide für 15 Zyklen inkubiert. Die Fusion beider Produkte erfolgte über die zuvor eingefügten 27 Nukleotide im Überlappungsbereich zwischen HC9-3' und 5'-IgDTM. Durch Zugabe der beiden flankierenden Oligonukleotide \#0169 und \#0172 und Durchführung weiterer 15 Zyklen konnte eine größere Produktausbeute erzielt werden. Die Komplettierung der sekretorischen Variante beschränkte sich auf das Anfügen der fehlenden 3'-Nukleotide sowie dem Kozak-Startkodon. Die beiden Oligonukleotide \#0169 und \#0179 amplifizierten ein 1377 bp großes PCR-Produkt, welches im Vergleich zur transmembranen Variante das C-terminale Lysin mit nachfolgendem Stopkodon enthielt.

Gleiches Verfahren galt für die leichte Kette LC8d des MA18/7-Antikörpers. Das Signalpeptid und Kozak-Startkodon wurden in einer PCR durch die Oligonukleotide \#0218 und \#0214 (Signalpeptid) bzw. \#0219 und \#0214 (Kozak-Startkodon) wiederhergestellt. Hierbei wurden auch 33 zusätzliche Nukleotide 5' an das Gen fusioniert, welche die fehlenden Aminosäuren MESQTLVFISI- des Signalpeptids einfügten. Als Template diente das Plasmid pCR2.1KappaLC8d.Die anschließende Klonierung beider Varianten der schweren Kette (IgGHC9* und IgGHC9TM) sowie der leichten Kette (KappaLC8d) erfolgte direkt in den Vektor pCR2.1 über die durch die PCR angefügten A-Überhänge (3.1.7). Die Konstruktionen wurden daraufhin durch Sequenzierung auf ihre Richtigkeit und auf Mutationen hin überprüft (3.1.5). Für die Versuche in Zellkultur wurden die Konstrukte aus den pCR2.1-Plasmiden über die Restriktions- 
a)

\#0169
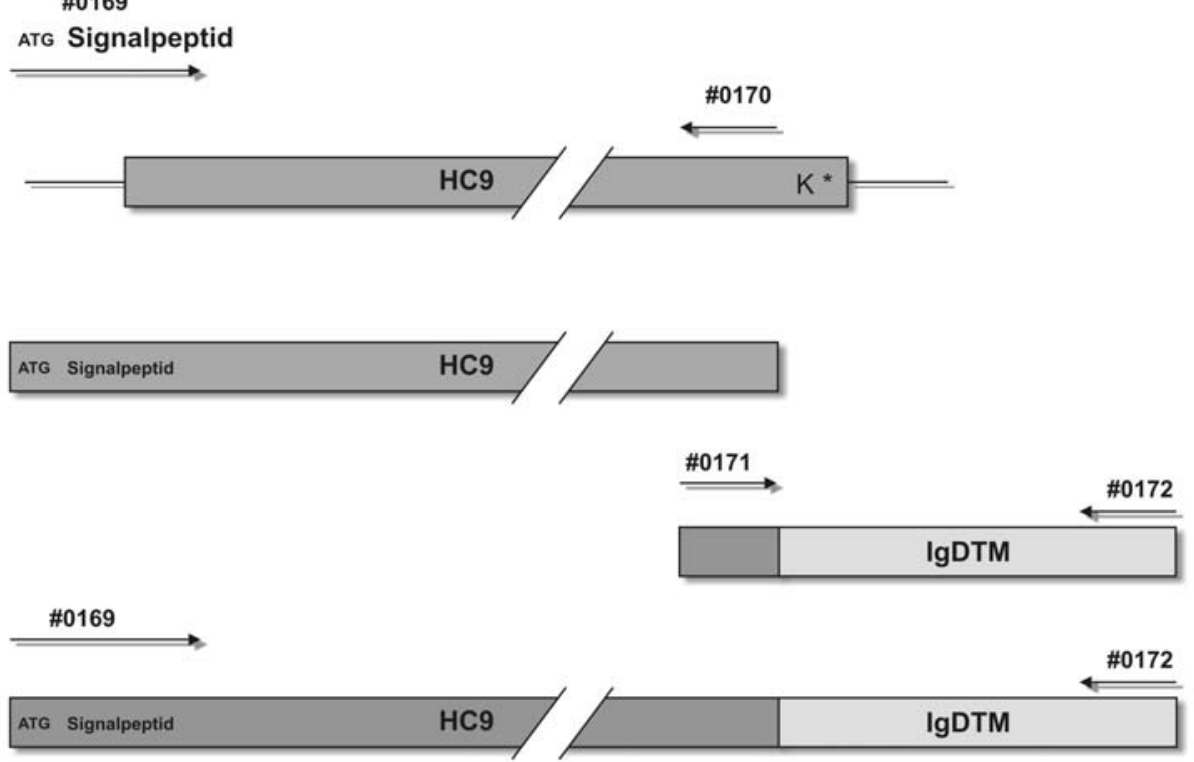

b)

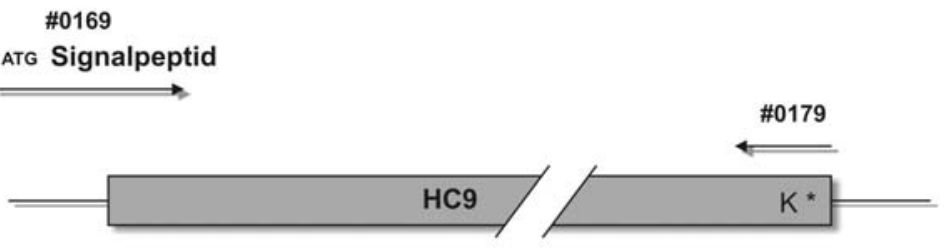

ATG Signalpeptid $\mathrm{HC9} \mathrm{K}^{*}$

c)

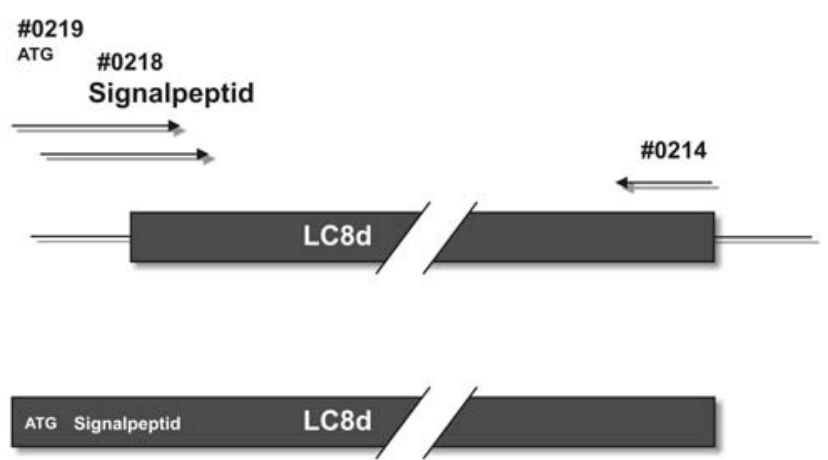

Abb. 23: Graphische Darstellung der Herstellung a) der transmembranen Variante sowie b) der sekretorischen Variante der schweren Kette IgGHC9 und c) der leichten Kette KappaLC8d mittels PCR. 
schnittstellen HindIII und EcoRV in das eukaryotische Expressionsplasmid pSVBX24H (2.5) unter Austausch des S-Gens umkloniert.

\subsubsection{Nachweis der Produktion von MA18/7 in COS7-Zellen}

Zunächst sollte die Expression der MA18/7-Konstrukte in Zellkultur gezeigt werden. Hierfür wurden COS7-Zellen mit den zwei Konstrukten der schweren Ketten pSVLIgGHC9* (2.5), pSV-LIgGHC9IgDTM (2.5) und der leichten Kette pSV-KappaLC8d (2.5) einzeln transfiziert (3.3.3). In zwei weiteren Ansätzen wurde die transmembrane Variante der schweren Kette pSV-LIgGHC9IgDTM mit der leichten Kette pSV-KappaLC8d und die sekretorische Variante der schweren Kette pSV-LIgGHC9* in Kombination mit der leichten Kette pSV-KappaLC8d kotransfiziert. Drei Tage nach Transfektion wurden die exprimierten MA18/7-Konstrukte durch radioaktive pulse/chase-Markierung analysiert (3.3.9). Die Immunpräzipitation erfolgte mit einem an Protein-A-Sepharose gebundenen anti-Maus-Antikörper aus dem Kaninchen (3.1.8.1). Die Immunpräzipitate wurden nachfolgend in einem $11 \%$ igen Polyacrylamidgel aufgetrennt (3.1.8.2) und autoradiographiert (3.1.9).

Abbildung 24 zeigt ein Autoradiogramm des beschriebenen Experiments. Wie deutlich zu erkennen ist, werden die transmembrane Variante der schweren Kette HC9TM sowie die leichte Kette LC8d gebildet, nicht aber die sekretorische Variante HC9*. Die transmembrane Variante der schweren Kette zeigt erwartungsgemäß lediglich im Zelllysat ein Signal bei etwa 50 bis $55 \mathrm{kD}$, was auf eine funktionelle Transmembrandomäne rückschließen lässt. Der Nachweis der sekretierten leichten Kette im Zellkulturüberstand zeigt eine erfolgreiche Wiederherstellung der Signalpeptidsequenz. Während die leichte Kette im Zelllysat und im Kulturüberstand nachgewiesen werden konnte, beschränkte sich der Nachweis der transmembranen schweren Kette ausschließlich auf die Zelllysate. Für beide Ketten kann etwa das gleiche Expressionslevel verzeichnet werden. Ein Vergleich der Expression der leichten Kette mit der Koexpression der leichten und schweren transmembranständigen Kette zeigt, dass die leichte Kette koexprimiert mit der schweren Kette offenbar in oder auf den 
Zellen zurückgehalten wird, während die leichte Kette alleine exprimiert überwiegend ins Medium sezerniert wird. Die Gesamtexpression zellulärer und sezernierter MA18/7Konstrukte ist etwa gleich.

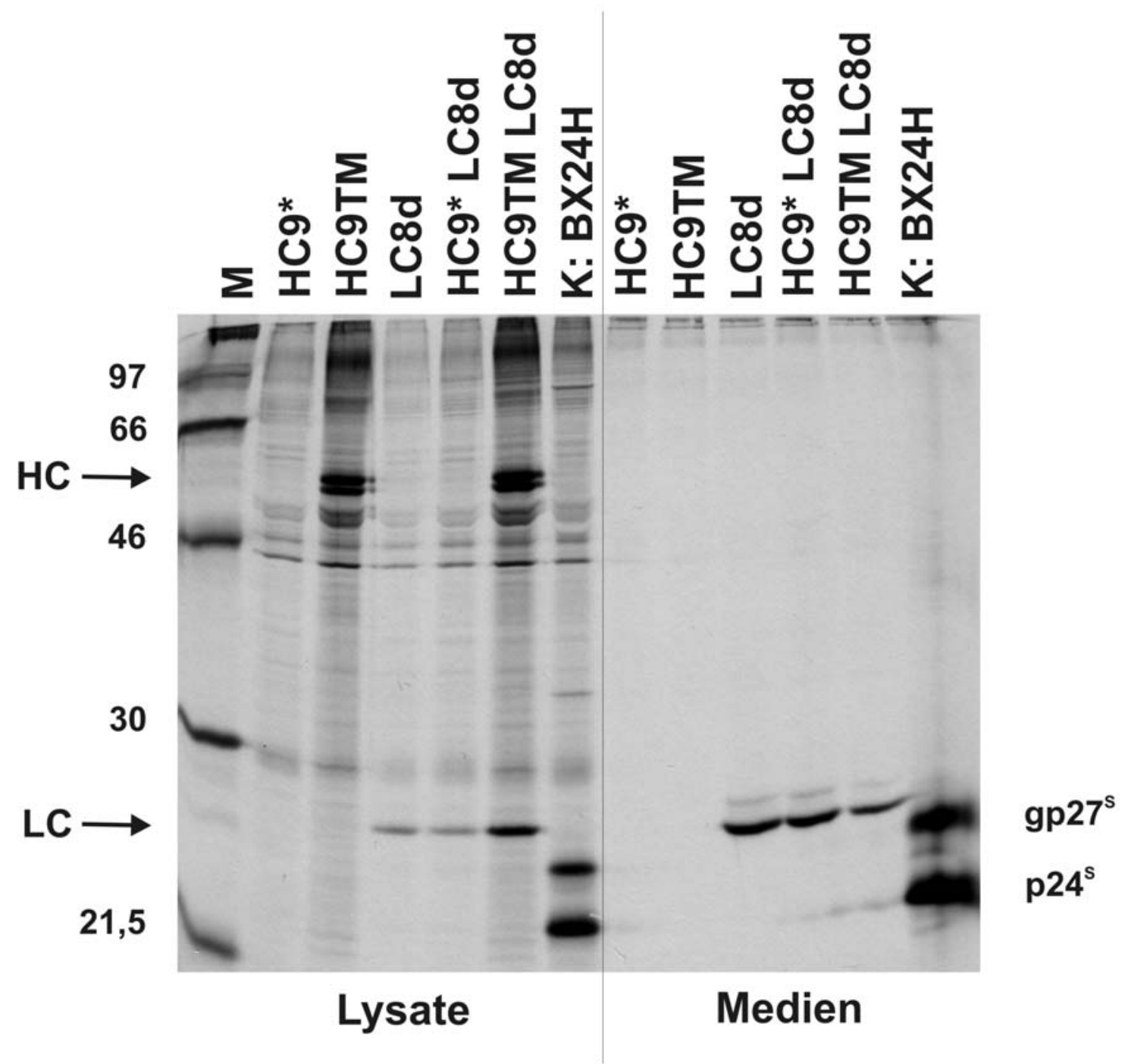

Abb. 24: Autoradiographische Darstellung der durch pulse/chase-markierten und immunpräzipitierten MA18/7-Konstrukte nach Transfektion in COS7-Zellen. Auf der linken Seite sind die Immunpräzipitate der Zelllysate, auf der rechten Seite die der Medien aufgetragen. Die Pfeile markieren die Höhe der Banden der schweren Kette (oberer Pfeil) und der leichten Kette (unterer Pfeil). Als Kontrolle (K) diente eine Transfektion des Plasmids pSVBX24H. Das exprimierte HBsAg wurde mit einem anti-HBs-Antikörper immunpräzipitiert und parallel mitbehandelt.

Es ist deutlich zu erkennen, dass sowohl die transmembrane Variante der schweren Kette HC9TM als auch die leichte Kette LC8d in den Zellen exprimiert wurde. Die Sekretion der leichten Kette LC8d lässt auf eine erfolgreiche Wiederherstellung des Signalpeptids schließen. 


\subsubsection{Nachweis der Oberflächenpräsentation von MA18/7}

Durch den zuvor beschriebenen Versuch 4.1.3 konnte bereits gezeigt werden, dass die leichte Kette LC8d bei Koexpression mit der transmembranen schweren Kette in bzw. auf den Zellen zurückgehalten wird. Nachfolgend sollte versucht werden, die Lokalisation des MA18/7-Antikörpers mittels Immunfluoreszenz mit einem konfokalen Mikroskop optisch darzustellen. Die Möglichkeit dieses mikroskopischen Verfahrens erlaubt eine räumliche Lokalisation der Signale in der Zelle. So sollte es möglich sein, eine Assoziation des MA18/7-Antikörpers auf der Zellmembran nachweisen zu können. Hierbei kam ein fluoreszenzmarkierter Antikörper zum Einsatz, der gegen die konstante Region der schweren und leichten Kette des IgG aus der Maus gerichtet war. Das Testen nichtpermeabilisierter MA18/7-transfizierter Zellen mit intakter Zellmembran erlaubt sogar eine Aussage über eine Orientierung des Antikörpers nach außen.

COS7- und HuH7-Zellen wurden mit den Plasmiden transfiziert, die die leichte Kette pSV-KappaLC8d und die transmembrane Version der schweren Kette pSV-LIgGHC9IgDTM des MA18/7-Antikörpers exprimieren (3.3.2; 3.3.3). Drei Tage später wurden die Zellen mit $4 \%$ Paraformaldehyd fixiert (3.3.7) und mit einem Cy2-konjugierten Ziege-anti-Maus-IgG(H+L)-Antikörper (Dianova, Hamburg) markiert (3.3.7). Permeabilisierung der Zellen mit 0,5 \% Saponin sollte ein zelluläres Signal zum Nachweis der Produktion von MA18/7 generieren. Die Markierung nichtpermeabilisierter Zellen sollte dazu führen, dass das Konjugat die fixierten Zellen lediglich von außen erreicht, so dass ein Signal auf die Präsenz des MA18/7Antikörpers in der Zellmembran mit einer nach außen gerichteten Orientierung rückgeführt werden konnte. Als Kontrollexperimente für den das Konjugat betreffenden Passageblock nichtpermeabilisierter Zellen wurden Zellen mit einem Antikörper markiert, der gegen den zytosolisch lokalisierten Transkriptionsfaktor statl gerichtet war. Die Markierung mit einem Konjugat, das spezifisch für diesen Marker ist, sollte

nur bei permeabilisierten Zellen ein Signal erzeugen. Andernfalls stellte die Zellmembran keine Barriere für das verwendete Konjugat dar, was zu einer falschen Interpretation bezüglich der Orientierung von MA18/7 führen könnte.

In Abbildung 25 sind die Ergebnisse der konfokalen Fluoreszenzmikroskopie dargestellt. Teilabbildungen e) und f) zeigen, dass der konstitutiv exprimierte zelluläre 
Faktor stat1 lediglich in den mit Saponin permeabilisierten Zellen nachgewiesen werden konnte. Eine Passage des Konjugats durch die Zellmembran in das Zytosol kann somit nur auf die mit Saponin behandelten Zellen beschränkt werden. Teilabbildungen a) und b) zeigen Bilder von transfizierten COS7-Zellen. In den Teilabbildungen c) und d) sind Transfektionen von HuH7-Zellen dargestellt. Es konnte für beide Zelllinien das gleiche Ergebnis beobachtet werden: Bei den Saponin behandelten Zellen war für MA18/7-transfizierte Zellen ein über das Zytosol homogen verteiltes Signal zu erkennen, was auf eine erfolgreiche Produktion des MA18/7-Antikörpers schließen ließ. Die nichtpermeabilisierten Zellen zeigten für transfizierte Zellen Signale, die auf die Zellmembran beschränkt werden konnten. Dies erlaubt folglich die Aussage, dass MA18/7 tatsächlich membranassoziiert sein muss und nur nach außen gerichtet vom Konjugat markiert werden konnte.

Abb. 25: (nächste Seite): Immunfluoreszenzmikroskopie MA18/7-transfizierter COS7Zellen a), b) und HuH7-Zellen c), d) jeweils mit transmembraner Variante der schweren Kette HC9TM und der leichten Kette LC8d. a), c) und e) repräsentieren die Bilder der Zellen, die bei der Fixierung permeabilisiert wurden (+Saponin). In den Teilabbildungen b), d) und f) sind die Immunfluoreszenzen der nichtpermeabilisierten Zellen (-Saponin) dargestellt. Die Zellen wurden unspezifisch mit Propidiumjodid (rot) gefärbt. Das verwendete Cy2-markierte Konjugat verursacht bei spezifischer Bindung ein grünes Signal. Kolokalisationen erscheinen in Gelb.

Der Kontrollversuch e) und f) zeigt, dass der konstitutiv exprimierte Faktor stat1 lediglich nach Permeabilisierung durch Saponin in Teilabbildung e) nachweisbar ist. Beide Zellkulturen zeigen nach Transfektion der MA18/7-Konstrukte membranassoziierte Signale der nichtpermeabilisierten Zellen (-Saponin), welche sich deutlich von den breiten zytosolischen Signalen der permeabilisierten Zellen (+Saponin) unterscheiden. 

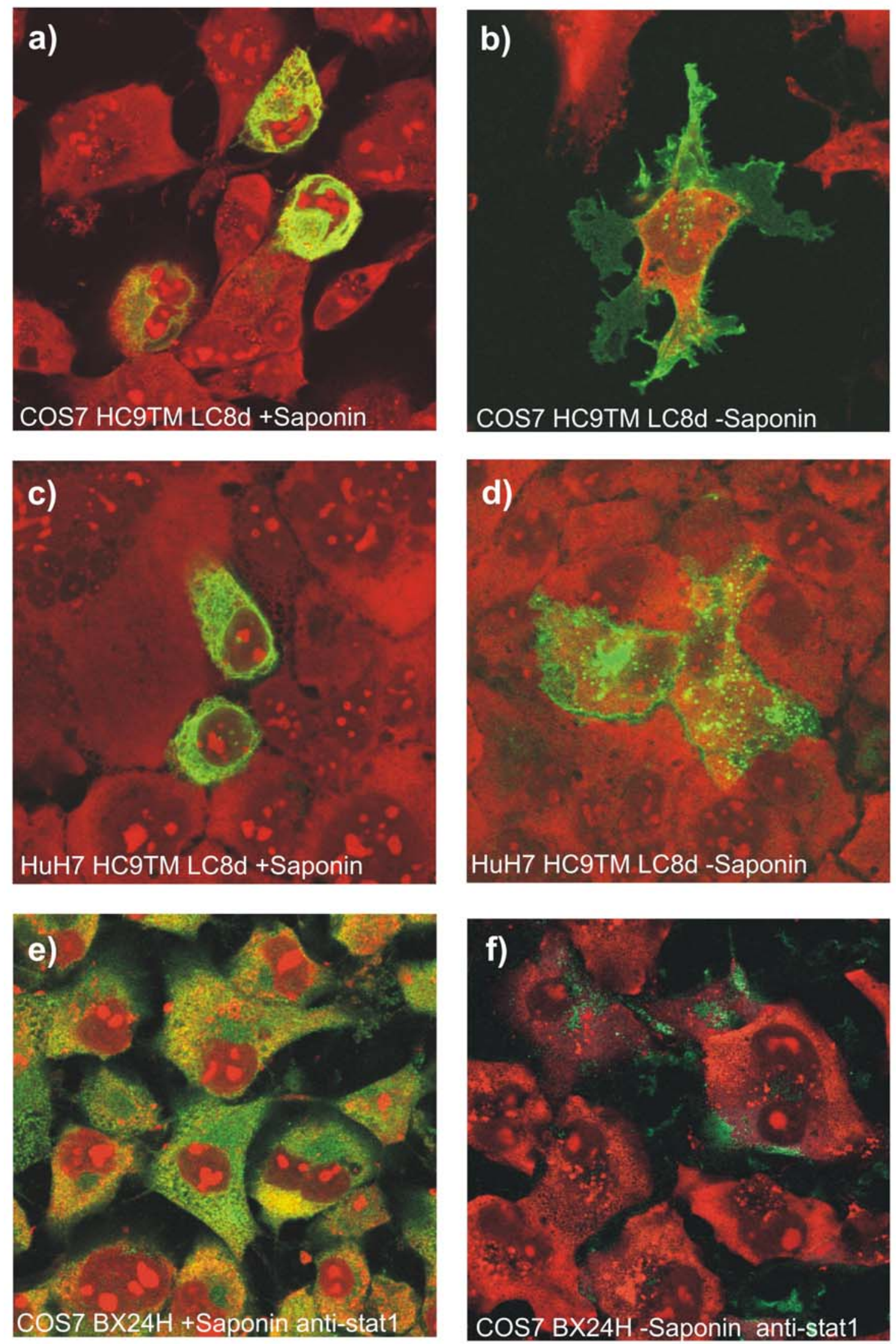


\subsubsection{Nachweis der Bindung von HBsAg an MA18/7-transfizierten Zellen}

Nachdem die Lokalisation des MA18/7-Antikörpers mit richtiger Orientierung nach außen in der Zellmembran aufgezeigt wurde, sollte nachfolgend versucht werden, die Bindung von HBV-Filamenten an MA18/7-transfizierten Zellen mittels Immunfluoreszenzmikroskopie nachzuweisen.

COS7-Zellen wurden mit den Plasmiden pSV-KappaLC8d und pSV-LIgGHC9IgDTM, die die leichte Kette und die transmembrane Version der schweren Kette des MA18/7Antikörpers exprimieren, transfiziert (3.3.2). Drei Tage nach Transfektion wurden die Zellen mit $4 \%$ Paraformaldehyd fixiert (3.3.7) und mit $4 \mu$ eines hochtitrigen HBVPatientenserums inkubiert $\left(\sim 10^{6}\right.$ Virionen/ $\left.\mu l\right)$. Bei den Proben zur Inkubation mit Virusfilamenten wurde während der Fixierung auf eine Permeabilisierung durch Saponin verzichtet. Der Nachweis von Virusfilamenten erfolgte mit einem anti-HBsAntikörper aus der Ziege, der wiederum mit einem Cy3-markierten anti-Ziege-Konjugat nachgewiesen wurde, welcher ein Signal im Rotkanal erzeugte.

Abbildung 26 zeigt die Ergebnisse nach konfokaler Fluoreszenzmikroskopie. Die Teilabbildungen a) und c) zeigen jeweils einen Overlay des Phasenkontrast- und Rotkanals. In Teilabbildungen b) und d) sind jeweils nur die Rotkanäle dargestellt. Die Teilabbildungen a) und b) zeigen den Nachweis von Filamentbindung an MA18/7transfizierten COS7-Zellen. Die in Teilabbildung b) zu sehenden spotartigen Signale, die einen Teil der Zellen umranden, deuten auf einen Nachweis gebundener HBVFilamente hin. Vergleiche mit der in Teilabbildung c) dargestellten Negativkontrolle nichttransfizierter markierter Zellen lassen jedoch keine eindeutige Aussage zu. Auch hier sind teilweise Signale zu erkennen, die als unspezifisch gedeutet werden müssen. Teilabbildung d) zeigt als Positivkontrolle HBsAg-produzierende COS7-Zellen nach Transfektion von pSVBX24H, die permeabilisiert mit dem gleichen Konjugat markiert wurden.

Eine eindeutige Aussage über die Fähigkeit MA18/7-transfizierter Zellen HBVFilamente zu binden, konnte mit diesem Versuch nicht getroffen werden. 

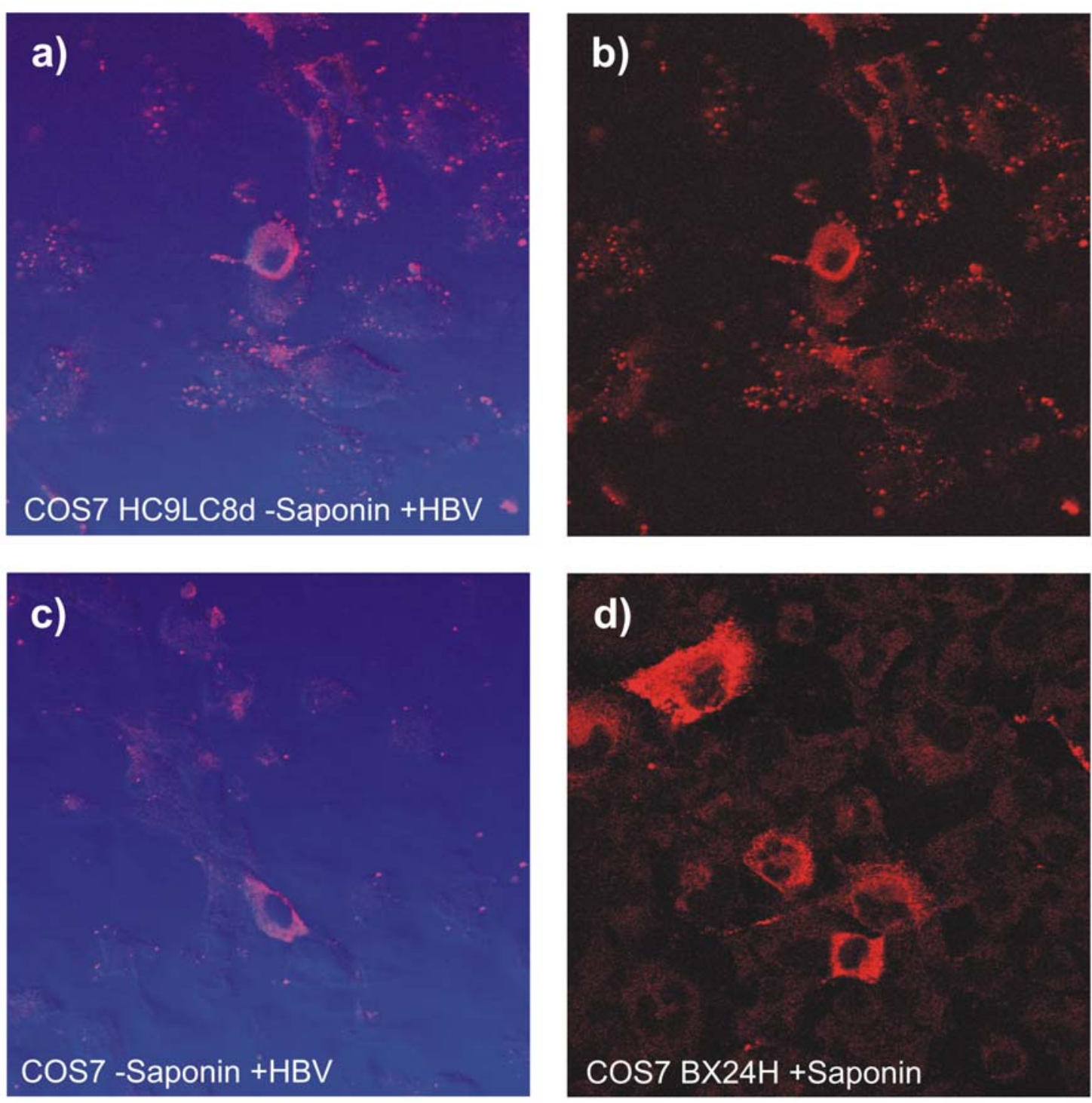

Abb. 26: Immunfluoreszenzmikroskopie von COS7-Zellen in a) und b) transfiziert mit transmembraner schwerer Kette pSV-LIgGHC9IgDTM und leichter Kette pSV-LKappaLC8d, d) Positivkontrolle transfiziert mit pSVBX24H und c) nichttransfizierte COS7-Zellen. Die Zellen der Teilabbildungen a) b) und c) wurden nichtpermeabilisiert mit HBV-Filamenten inkubiert, die anschließend über einen anti-HBs-Antikörper mit einem Cy3-markierten Konjugat nachgewiesen wurden. Als Positivkontrolle zeigt die Teilabbildung d) HBsAg-exprimierende COS7-Zellen, die permeabilisiert mit dem Cy3markierten Konjugat inkubiert wurde.

Die Interpretation spezifischer spotartiger Signale in den Teilabbildungen a) und d) relativieren sich im Vergleich $\mathrm{zu}$ den als Hintergrund $\mathrm{zu}$ deutenden Signalen in Teilabbildung c). 


\subsubsection{Nachweis der Bindung von HBV-Virionen an MA18/7-transfizierten Zellen}

Im nachfolgend beschriebenen Experiment sollte die Bindung von HBV-Virionen an MA18/7-transfizierten Zellen durch Nachweis mittels PCR (3.1.2.1) erfolgen. Die PCR erlaubt einen hochempfindlichen Nachweis von nur wenigen Genomen pro Reaktion.

COS7- und HuH7-Zellen wurden mit den Plasmiden pSV-KappaLC8d und pSV-LIgGHC9IgDTM, die die leichte Kette und die transmembrane Version der schweren Kette des MA18/7-Antikörpers exprimieren, transfiziert (3.3.2; 3.3.3). Drei Tage nach Transfektion wurden die Zellen mit $2 \times 10^{6}$ Virionen pro 3-cm-Schale für drei Stunden bei $37^{\circ} \mathrm{C}$ inkubiert (3.3.8.1). Anschließend wurden die Zellen fünfmal mit PBS gewaschen und lysiert (3.3.6). Nach Aufarbeitung der Zelllysate und Isolierung der Gesamt-DNA (3.3.8.3) wurden die Proben in einer Verdünnungsreihe bis $10^{-5}$ verdünnt. In einer HBV-Nachweis-PCR (3.1.6.4) mit den Oligonukleotiden \#0285 und \#0152 sollte das erwartete Amplifikat eine Größe von 631 bp haben.

Es war zu erwarten, dass sowohl transfizierte als auch nichttransfizierte Zellen positive Signale in der Nachweis-PCR generieren würden. Auch intensives Waschen der Zellen nach Inkubation mit Virionen würde zu Signalen bei nichttransfizierten Zellen führen, die durch unspezifische Bindungsereignisse von Virionen auf der Zelloberfläche zu Stande kommen. Für eine Interpretation des Ergebnisses ist vor allem das Signalverhältnis transfizierter zu nichttransfizierten Zellen von Bedeutung.

Abbildung 27 zeigt das Ergebnis der Nachweis-PCR nach Auftrag auf einem Agarosegel (3.1.4.6). Die Signale der $10^{-2}$-Verdünnungen sind im Vergleich zu den übrigen Signalen schwächer, da hier offenbar zu viel zelluläre DNA die PCR-Reaktion hemmte. Die linken Spuren der MA18/7-transfizierten Zellen zeigen ein deutliches Signal erwarteter Größe in allen Verdünnungsstufen und für beide Zelllinien. Parallel dazu konnte gleichzeitig für die nichttransfizierten Zellen deutlich weniger Virus-DNA nachgewiesen werden, welche mit den transfizierten Zellen stets gleich behandelt wurden. Eine spezifische Bande ist hier lediglich schwach in den Verdünnungen $10^{-2}$ und $10^{-3} \mathrm{zu}$ erkennen. Das Signalverhältnis transfizierter Zellen zu nichttransfizierten zeigt, dass die MA18/7-transfizierten Zellen in der Lage sind, mindestens 100-fach mehr Virionen zu binden als vergleichsweise nichttransfizierte Zellen. 
Es konnte hiermit gezeigt werden, dass das transfizierte MA18/7-Konstrukt Virionenbindung vermittelt.

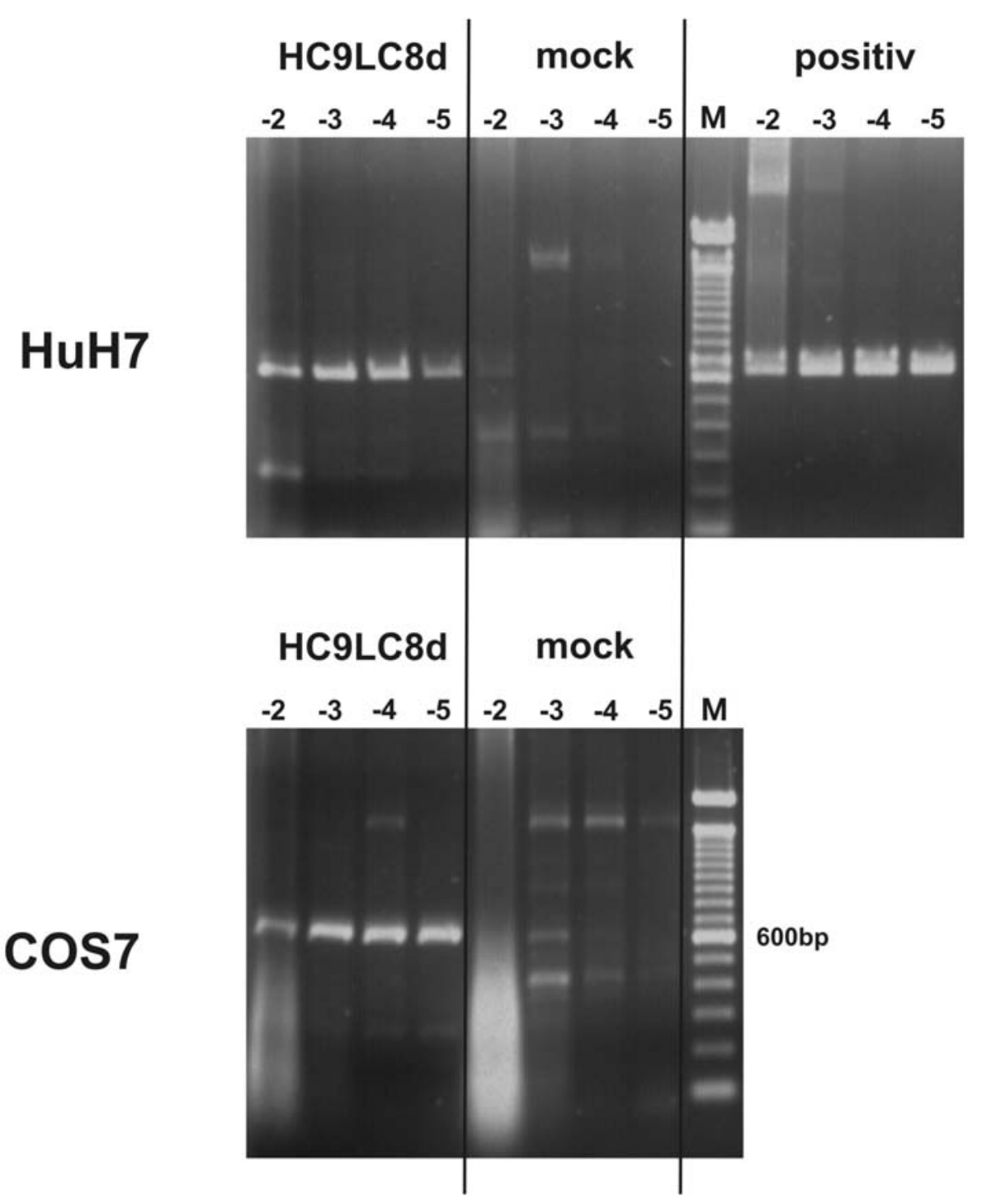

Abb. 27: HBV-Nachweis-PCR nach Virionenbindung an MA18/7-transfizierten (HC9LC8d) und nichttransfizierten (mock) HuH7- und COS7-Zellen. Beide Zelllinien zeigen nach Transfektion des MA18/7-Konstrukts deutliche PCR-Signale, die auf eine Bindung von HBV-Virionen bis zu einer Verdünnungsstufe von $10^{-5}$ hinweisen. Im Vergleich dazu sind bei den nichttransfizierten Zellen, die das gleiche Protokoll durchliefen, nur leichte Signale bis zur Verdünnungsstufe $10^{-3}$ zu erkennen. 


\subsubsection{Infektionsversuch}

Als abschließender Teil dieses Projekts galt der Versuch der Infektion MA18/7transfizierter Hepatoblastomzellen wie HuH7- oder HepG2-Zellen mit HBV-Virionen.

Hierfür wurden jeweils eine 10-cm-Schale HuH7- oder HepG2-Zellen mit den Plasmiden pSV-KappaLC8d und pSV-LIgGHC9IgDTM, die die leichte Kette und die transmembrane Version der schweren Kette des MA18/7-Antikörpers exprimieren, transfiziert (3.3.2). Als Negativkontrolle wurde eine weitere Schale HuH7-Zellen mit dem Plasmid pSV65 (leerer Vektor) transfiziert. Drei Tage nach Transfektion wurden die Zellen für mindestens drei Stunden mit $2 \times 10^{7}$ Virionen unter gelegentlichem Schwenken inkubiert. Anschließend wurden die Schalen fünfmal mit PBS gewaschen und mit frischem Medium versehen.

Das gleiche Protokoll wurde unter verschiedenen Mediumbedingungen durchgeführt. Die Arbeitsgruppe Gripon beschrieb bereits, dass die Infektionsraten primärer Hepatozyten durch Substitution der Kulturmedien mit Polyethylenglycol (PEG) und 1,5-2 \% Dimethylsulfoxid (DMSO) deutlich steigerbar sind (GRIPON et al., 1988; GRIPON et al., 1993). Auch das oben benannte Protokoll wurde unter Substitution von $2 \%$ DMSO und 1,5\% PEG durchgeführt.

Eine weitere Modifikation des obigen Protokolls bestand darin, die Zellen nach der Virusinkubation kurzzeitig einem sauren $\mathrm{pH}$ zu unterziehen. Nach Inkubation der transfizierten Zellen für drei Stunden mit $2 \times 10^{7}$ Virionen wurden die Zellen für 15 Minuten in PBS pH 4,5 inkubiert. Anschließend wurden die Zellen, wie bereits beschrieben, gewaschen und mit frischem Medium versorgt.

Während aller Infektionsversuche wurden für die folgenden 10 Tage nach der Virusinkubation täglich Mediumproben genommen und sowohl HBsAg- als auch HBeAg-Gehalt durch die Virusdiagnostik bestimmt, die als klassische Marker einer HBV-Infektion gelten. Bei keinem der Infektionsversuche konnte während der 10 Tage ein Anstieg einer der beiden Werte beobachtet werden. Eine erfolgreiche Infektion konnte somit nicht nachgewiesen werden. 


\section{DISKUSSION}

\subsection{Kartierung von Aminosäuren, die an der Umhüllung des Nukleokapsids beteiligt sind}

Vergleicht man das Hepatitis-B-Virus mit anderen Viren, muss man es in die Gruppe der Viren mit der höchsten spezifischen Infektiösität einordnen. Nahezu jedes Virion, das aus der Zelle entlassen wird, ist infektiös. Diese hohe spezifische Infektiösität ist auf eine effektive Qualitätskontrolle bei der Umhüllung der Nukleokapside rückzuführen. Zentraler Punkt dieser Kontrolle ist die Umhüllung des reifen Nukleokapsids in der späten Phase der Infektion bei der Produktion von HBV-Virionen. Nur vollständig gereiften Nukleokapsiden wird im letzten Schritt der Virusproduktion die Kompetenz vermittelt, am Endoplasmatischen Retikulum (ER) umhüllt zu werden, um anschließend durch zelluläre Exportmechanismen aus der Zelle in den Blutstrom entlassen zu werden (Gerelsaikhan et al., 1996; WeI et al., 1996; Perlmann, 2003). Als grundlegender Schritt für die Umhüllung wird ein direkter Kontakt zwischen reifem Nukleokapsid und den transmembranen Hüllproteinen postuliert.

Die drei HBV-Hüllproteine $\mathrm{S}, \mathrm{M}$ und $\mathrm{L}$ liegen als transmembrane Proteine in der ER-Membran vor, die mehrmals die Membran durchspannen und untereinander Homound Heterodimere bilden (BRUSS et al., 1996). Neben der Beobachtung der unabhängigen Bildung subviraler Partikel ist für die Bildung von Virionen lediglich das große (L) und das kleine (S) Hüllprotein notwendig (BRUSS und GANEM, 1991). Der N-terminale Bereich des L-Proteins befindet sich initial auf der cytosolischen Seite der ER-Membran. Zwei Regionen in Endodomänen der Hüllproteine wurden mittels Mutationsanalysen als Interaktionskandidaten des Umhüllungsprozesses identifiziert: Mutationen in einem linearen Bereich von 22 Aminosäuren zwischen Position 103 und 124 mit alleiniger Präsenz im L-Protein (BRUSS, 1997; LE SEYEC et al., 1999) sowie eine zweite Region zwischen Position 35 und 46 im Bereich des S-Proteins (LÖFFLERMARY et al., 2000), führten zum spezifischen Block der Umhüllung reifer Nukleokapside, erlaubten jedoch weiterhin die Sekretion subviraler Partikel. Es besteht die 
Vorstellung, dass die N-terminale Schleife des großen Hüllproteins als Kontaktpartner einer Protein-Proteininteraktion mit dem Nukleokapsid in Verbindung tritt, um dieses zum Zweck der Umhüllungsreaktion näher an die Membran des ER zu rekrutieren. Die Tatsache, dass lediglich reife Nukleokapside umhüllt werden, verleiht dieser Reaktion einen besonderen Charakter. Die vollendete Reifung des Nukleokapsids muss zu einer konformationellen Änderung der Kapsidoberfläche führen, die es wiederum der Umhüllungsreaktion erlaubt, zwischen reifen und unreifen Nukleokapsiden zu diskriminieren. Die Interaktion beider Bindungspartner muss demnach hochspezifisch sein und einem Schlüssel-Schloss-Prinzip folgen.

Diskutiert werden im Zusammenhang mit der Konformationsänderung des Nukleokapsids nach erfolgreicher Reifung vor allem Veränderungen des argininreichen C-Terminus des Coreproteins, dessen Lokalisation und Phosphorylierungszustand. Zum einen hat der C-Terminus die Aufgabe der Verpackung des RNA-Prägenoms während des Kapsidzusammenbaus sowie auch Funktionen während der DNA-Synthese im Inneren des Kapsids (SCHLICHT et al., 1989; GALlinA et al., 1989; Yu und SUMMERS, 1991; Hatton et al., 1992; NASSAL, 1992a; ZHOU und StANDERING, 1992; BEAMES und LANDFORD, 1993). Zum anderen konnte aber auch gezeigt werden, dass teilweise C-Termini reifer Nukleokapside auch nach außen exponiert sind (SCHLICHT et al., 1989). Es ist auch beobachtet worden, dass im Gegensatz zu intrazellulären Kapsiden sekretierte Virionen überwiegend dephosphorylierte C-Termini besitzen (PUGH et al., 1989; SCHLICHT et al., 1989).

Vorstellbar wäre aber auch, dass nicht der direkte Kontakt des C-Terminus das Reifungssignal über den Phosphorylierungszustand oder der Translokation vermittelt, sondern dass sekundäre Ereignisse, wie Dephosphorylierungen oder Translokalisationen von Bereichen des Kapsids als Reifungssignal, zu einem Rearrangement und einer Demaskierung einzelner für einen Kontakt $\mathrm{zu}$ den Hüllproteinen wichtigen Aminosäuren auf der Kapsidoberfläche führt. Bisher sind Strukturen, die dem reifen Nukleokapsid den Kontakt zu den Hüllproteinen ermöglichen, noch nicht identifiziert worden. 
Die Untersuchungen dieser Arbeit zur Interaktion des Nukleokapsids mit den Hüllproteinen während der Reifung bezogen sich auf den N-terminalen strukturbildenden Teil des Coreproteins bis Aminosäure 140 einschließlich.

Die Grundhypothese, auf der diese Arbeit basierte, war die Postulierung einer direkten Protein-Proteininteraktion der Hüllproteine mit Aminosäuren, die auf der Oberfläche des reifen Kapsids lokalisiert sind.

\subsubsection{Kristallstrukturanalyse des Coreproteins und Auswahl der Kandidaten}

Grundlage der Auswahl der Kandidaten für eine gerichtete Punktmutagenese im Coreprotein war eine umfassende Analyse der Kristallstruktur des Coreproteins als Monomer, Dimer und im Verbund zweier Dimere (WYNNE et al., 1999). Es wurden jene Aminosäuren genauer betrachtet, die im Kapsid oberflächenexponiert vorlagen. Letztendlich können nur oberflächenexponierte Aminosäureseitenketten für eine Interaktion mit den Hüllproteinen zur Verfügung stehen.

Das Coreprotein kann grob in drei verschiedene Bereiche eingeteilt werden, die mehr oder weniger stark kapsidoberflächenexponiert sind: Der N-terminalen Schleife um den Spike, den Spike an sich und der C-terminalen Schleife, die letztendlich ins Kapsidlumen abtaucht.

Der erste Bereich beginnt am N-Terminus des Coreproteins von Aminosäure 1 bis 49 und zieht sich in einer Schleife um den orthogonal ausgerichteten Spike. Zwei $\alpha$-Helices befinden sich in dieser Schleife, wobei die erste Helix von fünf und die zweite von drei Aminosäuren unterbrochen werden. Als Kandidaten waren in diesem Bereich die N-terminal gelegenen zwei Aminosäuren D2 und D4 sowie die Positionen V13, E14, S17, F18, P20, S21, D22, S26, V27, R28, D29, L31 und D32 interessant, deren Aminosäureseitenketten nach außen gerichtet und frei zugänglich waren. Der Bereich zwischen der Helix $\alpha 1 \mathrm{a}$ und $\alpha 1 \mathrm{~b}$ (Position 6 -12) taucht in das Innere des Kapsids ab und war daher nicht von direktem Interesse. Durch Bindungsstudien mit Antikörpern konnte bereits gezeigt werden, dass ein Bereich von Aminosäure 9 bis 20 von außen nicht zugänglich ist (PUSHKO et al., 1994). Ebenso wird der Bereich nach Aspartat 32 
der Helix $\alpha 2 b$ vom N-Terminus des Dimerpartners verdeckt und taucht zudem in das Innere des Kapsids ab, bevor sich die Peptidkette als Spike wieder in Richtung Kapsidoberfläche emporhebt.

Der zweite Bereich definiert den aufsteigenden und absteigenden Ast des Spikes von Aminosäure 50 bis 109. Der Spike selbst besteht im Coreproteindimer aus einem 4-Helix-Bündel (ConwAY et al., 1997). Helix $\alpha 3$ bildet den aufsteigenden Ast, und Helix $\alpha 4 \mathrm{a}$ und $\alpha 4 \mathrm{~b}$ bilden den absteigenden Ast dieser Haarnadelstruktur, die auf der Spitze des Spikes ein kleines Plateau aus jeweils den drei Aminosäuren 77 - 79 bildet. Die Oberfläche des Spikes besteht hauptsächlich aus amphipatischen hydrophoben Aminosäuren, die durch intermolekulare Bindungen ihren Beitrag zur Dimerstabilisierung leisten (WYNNE et al., 1999). Eine Disulfidbrücke fixiert beide Haarnadelstrukturen innerhalb des Spikes an Position C61, die allerdings nicht essentiell für Dimer- und Kapsidbildung ist (NASSAL et al., 1992b; ZHENG et al., 1992; ZLOTNICK et al., 1996) sowie zwei Wasserstoffbrückenbindungen zwischen den Aminosäuren E64 und $\mathrm{K} 96_{2}$ und D78 $18_{1}$ und $77_{2}$ (Indizes geben die Dimerpartner an).

So wie der C-terminale Teil des ersten Bereichs im Inneren des Kapsids aufhört, beginnt der N-Terminus der Helix $\alpha 3$ des aufsteigenden Astes auch im Inneren. Die ersten acht Aminosäuren werden ebenso wie die Helix $\alpha 2 b$ vom N-Terminus des Dimerpartners verdeckt und schieden für eine Mutagenese somit aus. An beiden Helices der Haarnadelstruktur des Spikes waren Seitenketten $\mathrm{zu}$ finden, die in Richtung Kapsidoberfläche gerichtet waren. Für die Helix $\alpha 3$ waren dies die Aminosäuren I59, L60, W62, M66, T67, T70 und G73 und für die Helix $\alpha 4$ des absteigenden Astes die Aminosäuren R82, D83, L84, N87, N90, T91, N92, L95, K96 und R98. Der C-Terminus der Helix $\alpha 4 b$ taucht ab Position 99 wiederum in das Innere des Kapsids ein und wird durch die ringförmige Schleife um den Spike verdeckt. Die Spitze des Spikes wird durch die Aminosäuren N74, N75, L76, E77, D78 und P79 gebildet. Ihre Seitenketten sind alle von außen zugänglich und stellten deshalb nach diesen Kriterien ausnahmslos Kandidaten dar.

Der strukturell dritte Bereich des Coreproteins bildet C-terminal eine Schleife, die auch einer Haarnadelstruktur ähnelt. Sie befindet sich unterhalb der ringförmig um den Spike angeordneten Schleife, etwa im $80^{\circ}$-Winkel in X-Achsenebene zum Spike ab 
Position 110. Diese Haarnadelstruktur beinhaltet N-terminal die Helix $\alpha 5$, und den C-Terminus, der in der Verlängerung als protaminähnliche Schleife in das Lumen des Kapsids abtaucht. Funktionell wird über den Bereich der C-Termini der Interdimerkontakt zu benachbarten Dimeren hergestellt. Die Spitze dieser Schleife eines Dimers interagiert hierbei sowohl mit der C-terminalen Schleife als auch mit Aminosäuren der ringförmigen N-terminalen Schleife des benachbarten Dimers.

Die Aminosäuren 110 bis 117 sind durch die N-terminale ringförmige Schleife komplett verdeckt und schieden für die Mutagenese aus. Ab Position 118 bis Position 140 fanden sich insgesamt 16 Aminosäuren, die ihre Seitenketten nach außen frei zugänglich positioniert haben. Dies waren die Aminosäuren Y118, L119, F122, W125, I126, R127, P129, P130, A131, Y132, R133, P135, N136, A137, I139 und L140. Die Aminosäuren nach Position 140 tauchen bereits in das Innere des Kapsids ab.

\subsubsection{An der Umhüllung beteiligte Aminosäuren}

Alle aufgeführten 52 Aminosäuren wurden einzeln zu Alanin (für A131 und A137 zu Glycin) verändert. Alanin mit einer Methylgruppe und Glycin mit einem Wasserstoff als Seitenkette verhalten sich neutral bezüglich ihrer Seitenkettenaktivität mit anderen Aminosäuren in einer Protein-Proteinwechselwirkung. So sollte der Phänotyp einer Mutante auf den Verlust der Seitenkettenaktivität an dieser Stelle rückschließen lassen. Nach Herstellung durch PCR und Verifizierung durch Sequenzierung wurden die Coremutanten auf ihre Umhüllungskompetenz hin getestet.

Insgesamt zeigten 11 Coremutanten den gesuchten Phänotyp: DNA-haltige Nukleokapside wurden gebildet, die Sekretion von Virionen ins Medium aber war blockiert.

Der Verlust der Umhüllungsreaktion einer Mutante kann unterschiedliche Ursachen haben. Zum einen kann dies die Ursache des Verlusts einer direkten Interaktionsstelle sein, die in Kontakt mit den Hüllproteinen tritt. Zum anderen wären aber auch andere Ursachen für den Verlust der Umhüllungskompetenz denkbar. Da letztendlich noch nicht bekannt ist, was das Reifungssignal reifer Nukleokapside ist, könnte beispielsweise durch Punktmutation auch dieses beschädigt worden sein. Sollte das 
Reifungssignal beispielsweise die Präsentation eines zuvor verdeckten Epitops auf der Oberfläche des Kapsids sein, so könnte auch durch Punktmutation nicht nur die Eigenschaft des Epitops selbst, sondern auch indirekt beispielsweise die Konformation benachbarter Bereiche verändert sein, die eine Präsentation des Epitops verhindert. Es muss auch in Erwägung gezogen werden, dass möglicherweise ein durch die Mutationen hervorgerufener Bindungsverlust bisher noch nicht bekannter dritter zellulärer Faktoren, die beispielsweise an der Rekrutierung des Nukleokapsids zur ER-Membran beteiligt sein könnten, für den Phänotyp dieser Mutanten verantwortlich sein könnten.

Betrachtet man die Lokalisation der Mutationen dieses Phänotyps, so fällt auf, dass sie nicht über das gesamte Protein verstreut, sondern in zwei räumlichen Klustern auftreten. sechs der elf Mutanten befinden sich in der C-terminalen Haarnadelschleife des dritten oben beschriebenen Bereichs des Coreproteins und sind sowohl in der Primärsequenz, vor allem aber in der Tertiärstruktur unmittelbar benachbart. Die Mutanten der Aminosäuren F122, I126 und R127 befinden sich auf der Helix $\alpha 5$, ihre WTSeitenketten waren direkt nach oben gerichtet. Die drei anderen in diesem Bereich der Primärsequenz lokalisierten Mutanten der Aminosäuren N136, A137 und I139 liegen direkt benachbart auf gleicher Höhe des rückführenden Strangs der C-terminalen Haarnadelschleife. N136 und A137 waren ursprünglich zu den Seiten gerichtet, während die Seitenkette von I139 nach oben zeigte. Bereits in früheren Versuchen der Arbeitsgruppe wurden bei Mutageneseexperimenten zwei Mutanten mit gleichem Phänotyp gefunden. Eine Deletionsmutante R133 - P135, bei der Prolin 134 fehlte sowie eine Insertionsmutante S141-L140, die zwei Aminosäuren inseriert hatte, bildeten zelluläre Nukleokapside, aber sekretierten keine Virionen mehr (KOSCHEL et al., 1999). Die Interpretation dieser beiden Mutanten muss sicherlich weiter gefasst werden als der Verlust einer Seitenkettenaktivität. Neben dem Funktionsverlust der Deletion kommt es sicherlich auch zu Verschiebungen der Positionen der nachfolgenden Aminosäuren durch Verkürzung oder Verlängerung des Proteins, so dass bei beiden Mutanten auch von einem sekundären Funktionsverlust anderer Seitenketten ausgegangen werden kann.

Bei näherer Betrachtung der Tertiärstruktur müssen zusätzlich zwei weitere Coremutanten unmittelbar mit in das erste Kluster eingeordnet werden. Die Mutanten 
der N-terminal gelegenen Aminosäuren S17 und F18 zeigten ebenfalls den umhüllungsinkompetenten Phänotyp. Diese sind auf der ringförmig um den Spike angeordneten Schleife lokalisiert, direkt benachbart oberhalb des eben beschriebenen Klusters der sechs C-terminalen Aminosäuren diesen Phänotyps. Die Seitenketten von S17 und F18 weisen seitlich vom Spike weg in die Richtung der schräg unter ihnen liegenden sechs C-terminalen Aminosäuren. Die unmittelbare Nähe der beiden Aminosäuren zu dem zuvor beschriebenen Kluster wird durch eine Wasserstoffbrückenbindung zwischen F18 mit R127 deutlich unterstrichen. Von der Seite betrachtet ergibt sich somit eine Treppenebene aus drei Stufen. S17 und F18 befinden sich auf der obersten Stufe auf der ringförmigen Schleife um den Spike, auf der mittleren Stufe darunter auf Helix $\alpha 5$ befinden sich F122, I126 und R127 und auf der untersten Stufe N136, A137 und I139. Die Assemblierung der Coreproteindimere findet kreisförmig um 5-fache und 6-fache Symmetrieachsen statt (CROWTHER et al., 1994). Die C-Termini sind hierbei zur Symmetrieachse hin gerichtet, stellen die Interdimerkontakte sicher und bilden im Fall der 6-fachen Symmetrie eine Kapsidpore. Betrachtet man die Lokalisation des C-terminalen Klusters, so fällt eine deutliche Konzentrierung dieser Kluster um die Kapsidpore auf.

Ein zweites Kluster ergibt sich durch die Coremutanten der Positionen L95, K96 und L60. Betrachtet man diese Positionen im Dimer, so fällt eine ringförmige Anordnung um den Spike an dessen Basis auf. L60 befindet sich hierbei auf dem aufsteigenden Ast der Helix $\alpha 3$ und liegt unmittelbar benachbart zu den Aminosäuren L95 und K96 der Helix $\alpha 4$ des absteigenden Astes des Dimerpartners. Interessanterweise wurden für diesen Bereich auch eine natürlich vorkommende Mutation beschrieben. Während die in dieser Arbeit charakterisierte Mutante L60A keine Virionen mehr sekretierte, konnte bei einer natürlich auftretenden Mutanten L60V eine signifikante Reduzierung an sekretierten Virionen verzeichnet werden. Durch Transkomplementationsversuche konnte dieser Effekt alleine auf die Veränderung des Coreproteins rückgeschlossen werden (LE POGAM et al., 2000).

Es ist auffällig, dass die in der Primärsequenz z.T. weit voneinander entfernten Aminosäuren mit Umhüllungsfunktion bei Betrachtung der Tertiär- und Quartärstruktur sich räumlich so nahe sind, so z.B. die Position 60 mit 95/96 oder Positionen 17/18 mit den Positionen 122/126/127 sowie 136/137/139. Beide Kluster sind unweit voneinander 
entfernt und auf jene Bereiche beschränkt, die die bodennahe Struktur des Dimers ausmachen.

Die strukturelle Oberfläche dieser Kluster im Dimer zeigten bei genauerer Betrachtung zwei Furchen. Eine Furche zieht sich entlang der Interdimerkontaktstelle in Richtung Kapsidpore und betrifft das erste C-terminale Kluster der acht beschriebenen Aminosäuren. Die zweite Furche zieht sich parallel dazu um die Basis des Spikes herum. Die Tatsache der Klusterbildung der Positionen dieses Phänotyps $(\mathrm{K}+\mathrm{V}-)$ bestärkt die Vermutung, dass diese Aminosäureseitenketten tatsächlich Kontakt zu den Hüllproteinen während der Umhüllung aufbauen. Hierbei ist nicht auszuschließen, dass diese Seitenketten auch gleichzeitig Bestandteil des Epitops sind, welches möglicherweise als Reifungssignal auf reifen Nukleokapsiden präsentiert wird. Vorstellbar wäre, dass Teile der N-terminalen Schleife des großen Hüllproteins, welche als Interaktionspartner vermutet werden (BRUSS, 1997; LE SEYEC et al., 1999), zwischen den Spikes auf den Boden des Kapsids abtauchen und mit den benannten Bereichen während der Umhüllung interagieren. Möglicherweise tauchen Schleifen der Hüllproteine genau in diese Furchen $a b$ und kontaktieren die dort beschriebenen Aminosäuren.

\subsubsection{Die Spitze des Spikes ist nicht an der Umhüllung beteiligt}

An der äußersten Peripherie des Nukleokapsids befinden sich die Spikes und deren Spitzen. Jedes Coreproteinhomodimer formt einen dieser aus der kugelförmigen Kapsidstruktur herausragenden Spitzen; bei dem aus 240 Coreproteinen zusammengesetzten $\mathrm{T}=4$ Modell ergibt sich eine Anzahl von 120 Spikes pro Kapsid.

Die dominanten Epitope $\mathrm{HBe} 1$ und $\mathrm{HBc}$, die in infizierten Leberzellen eine starke Immunantwort hervorrufen, befinden sich auf der Spitze des Spikes um Position 80 (SALFELD et al., 1989; SÄLlBERG et al., 1991). Es konnte zudem gezeigt werden, dass Kapside sehr gut als Träger fremder Epitope fungieren können. Insertionen bis 46 Aminosäuren zwischen den Aminosäuren 78 und 79 werden toleriert und führen 
ohne signifikante Beeinträchtigung dennoch zu stabiler Partikelbildung (BORISOvA et al., 1993).

In vitro Bindungsversuche zeigten, dass kurze aus einer Bibliothek selektionierte Peptide in der Lage sind, die Bindung der Hüllproteine am Nukleokapsid zu inhibieren (DYSON und MURAY, 1995). Elektronenmikroskopisch konnte später gezeigt werden, dass die Bindungen dieser Peptide an der Spitze des Spikes stattfanden. (BöTTCHER et al., 1998) Diese Experimente führten ursprünglich $\mathrm{zu}$ der Annahme, dass das Nukleokapsid während der Umhüllung Kontakt über die Spitzen der Spikes zu den Hüllproteinen aufnimmt.

In dieser Arbeit wurden insgesamt 23 Seitenketten des Spikes zu Alanin mutiert. Hierunter befanden sich auch die Aminosäuren, die die Spitze des Spikes bilden. Das Plateau des Spikes bilden die Aminosäuren E77, D78 und P79. Als benachbarte Positionen wurden zusätzlich die Aminosäuren G73, N74, N75 und L76 nach Alaninsubstitution auf Umhüllungskompetenz getestet. Bei keiner dieser Substitutionen wurde ein umhüllungsinkompetenter Phänotyp beobachtet. Alle Mutationen, die auf der Spitze des Spikes lokalisiert waren, zeigten keine Beeinträchtigung in der Bildung von Virionen mit Ausnahme der Alaninsubstitution an Position D78. Hier kam es zum Verlust der Bildung von Kapsiden. Im Strukturmodell zeigt D78 eine intramolekulare Wasserstoffbrückenbindung zu E77. Der Verlust dieser Wasserstoffbrückenbindung hätte diesen Phänotyp erklären können, jedoch zeigten weitere Versuche mit dieser Mutante, dass im Western-Blot nach PEG-Fällung transfizierter Zelllysate sowohl Kapside nachweisbar waren, als auch virale DNA durch Southern-Blot-Analyse nach Immunpräzipitation von Kapsiden nachgewiesen werden konnte (siehe auch 5.1.4). Es muss davon ausgegangen werden, dass die Mutation der Position 78 eventuell ein Defekt im Reifungssignal führt, so dass zwar reife Nukleokapside gebildet, jedoch nicht aus der Zelle ausgeschleust werden.

Neben dem Phänomen der Toleranz von Insertionen um Position A80 des Coreproteins hinsichtlich Partikelbildung (BORISOVA et al., 1993), konnten in der Arbeitsgruppe bereits für die Deletionsmutante P79-S81 die stabile Bildung von Kapsiden sowie keine Beeinträchtigung in der Sekretion von Virionen aufgezeigt werden (KOSCHEL et al., 1999). In einem weiteren Versuch wurden daraufhin zwei Dreifachmutanten 
hergestellt, die jeweils Alaninsubstitutionen an den Positionen N74, N75 und E77 sowie N75, E77 und P79 trugen. Hierdurch wurde erreicht, dass die gesamte Spitze des Spikes bezüglich Seitenkettenaktivität durch zweimal drei Alanine quasi neutralisiert wurde. Die Tatsache, dass sogar beide Dreifachmutanten noch in der Lage waren, Virionen zu sekretieren, bestätigte die Hypothese, dass die Spitze des Spikes für eine Hüllproteininteraktion zur Virionenbildung nicht notwendig ist.

\subsubsection{An der Partikelbildung beteiligte Aminosäuren}

13 der 52 durch die endogene Polymerase-Reaktion getesteten Coremutanten zeigten keine zytoplasmatischen Nukleokapside an.

Dieser Nachweis bedient sich der Tatsache, dass in Kapsiden und Virionen das Genom des Virus als partiell doppelsträngige DNA kovalent gebunden an die Viruspolymerase vorliegt. Auch nach Auflösung der Virushülle mit einem milden Detergenz bleibt ihre Aktivität erhalten. Der negative Nachweis kann sich somit nur auf das Fehlen replikationsfähiger Nukleokapside beziehen. Für ein positives Signal durfte eine Mutation keinen Effekt auf die Genomreifung haben. In den Mutanten musste ein partiell doppelsträngiges DNA-Genom vorliegen, in welches das radioaktiv markierte Nukleotid eingebaut werden konnte.

Es konnte nicht ausgeschlossen werden, dass eine Mutation auf der Oberfläche des Kapsids zu Beeinträchtigungen in der Prägenomverpackung oder Genomreifung führte, was sich auf das Signal in diesem Nachweis auswirken würde. Auch wenn der Sinn und Mechanismus des Synthesestopps der nicht vollständigen reversen Transkription des viralen Prägenoms noch nicht gänzlich verstanden ist, könnte ein Zusammenhang mit der Nukleotidversorgung des Kapsidlumens bestehen. Es wäre vorstellbar, dass Alaninsubstitutionen gerade im Bereich der Kapsidpore Veränderungen der Nukleotidversorgung des Kapsidlumens hervorrufen. Beispielsweise hätte eine Verengung oder Erweiterung der Kapsidporen möglicherweise eine Fehlversorgung des Kapsidlumens mit Nukleotiden zur Folge, gemessen am natürlichen Nukleotidgehalt des Kapsids. Möglicherweise ist gerade die richtige Konzentration an Nukleotiden für die lediglich 
partielle reverse Transkription des Prägenoms verantwortlich, so dass beispielsweise eine Weitung der Kapsidpore zu einer vollständigen reversen Transkription des Genoms und zu einem ausbleibenden Signal in der EPR führen würde.

Um die 13 EPR-negativen Coremutanten näher zu charakterisieren, wurden nachfolgend Untersuchungen angestellt, die die einzelnen Schritte bis hin zum DNA-haltigen Nukleokapsid nachweisen sollten. Im ersten Schritt wurde eine Western-Blot-Analyse nach PEG-Fällung zum Nachweis von partikulärem HBcAg durchgeführt (4.1.5.1). Die stärksten Signale wurden hier von den Mutanten D4, D29 und D78 generiert. Bemerkenswert war, dass die Mutanten D29 und D78 im elektrischen Feld des Agarosegels langsamer liefen, als Wildtyp-Kapside. Wahrscheinlich führte der Austausch der geladenen Aminosäure Aspartat durch das ungeladene Alanin vor allem auf der Spitze des Spikes zu einer derartigen Veränderung des Laufverhaltens. D78 und D29 zeigten das stärkste Signal im Immunblot und waren vergleichbar mit dem Signal des Wildtyps von ca. 5 bis $10 \mathrm{ng}$. Die anschließend durchgeführte Southern-BlotAnalyse nach Immunpräzipitation von Kapsiden mit einem polyklonalen anti-HBcAntikörper (4.1.5.2) zeigte, dass lediglich diese drei Mutanten D4, D29 und D78, die bereits im Western-Blot die stärksten Signale generierten, auch hier als einzige Coremutanten Signale verzeichneten. Verglichen mit dem Wildtyp befand sich jedoch deutlich weniger DNA in den Kapsiden. Dies könnte bedeuten, dass diese drei Mutanten möglicherweise Beeinträchtigungen in der Verpackung prägenomischer DNA beziehungsweise in der Genomreifung hatten. Der sehr geringe DNA-Gehalt der Kapside führte somit wahrscheinlich auch zu einem negativen Signal im Nachweis durch die EPR (4.1.3).

Die Mutanten P20, P129 und Y132 zeigten nur im Immunblot noch ganz schwache Signale unter $500 \mathrm{pg}$ Coreprotein. Während das Signal von P20 noch als distinkte Bande zu erkennen war, zeigten die anderen beiden Mutanten lediglich schmierartige Signale über einen breiten Bereich der Spur. Das geringe Signal der Mutante P20 zeigte, dass diese Mutante nicht mehr in der Lage war, ausreichend Kapside zu assemblieren. Unklar bleibt, ob die Mutation dem Coreprotein schon als Monomer oder Dimer Instabilität verleiht oder erst die Assemblierung zum Kapsid gestört gewesen ist. Jedoch besitzt die Position von P20 keine unmittelbare Nähe zum benachbarten Dimer, so dass eine direkte Beteiligung am Interdimerkontakt unwahrscheinlich ist. Anders hingegen 
sind die C-terminal lokalisierten Mutationen zu bewerten. Bemerkenswert ist, dass der überwiegende Anteil EPR-negativer Mutationen sich am C-Terminus des Coreproteins befindet. Die Mutanten Y118, W125, P130, R133 und L140 zeigten überhaupt kein Signal mehr im Immunblot nach PEG-Fällung (4.1.5.1). Alaninsubstitution an diesen Positionen führte offenbar zum Verlust der Kapsidassemblierung.

Im Gegensatz $\mathrm{zu}$ der in dieser Arbeit charakterisierten Mutante P130A, die die Fähigkeit zur Kapsidassemblierung verloren hatte, ist eine natürlich vorkommende Coremutante P130T noch in der Lage, Virionen zu bilden (YUANG und SHIH, 2000). Bemerkenswert ist auch, dass die Mutation P130T offenbar in der Lage ist, den Phänotyp einer weiteren natürlich vorkommenden Coremutante I97L, die unreife Virionen sekretiert, zu kompensieren (YUANG und SHIH, 2000).

Verschiedene Coremutanten, die aus einer Zufallsmutagenese selektioniert wurden, wurden bezüglich Kapsidassemblierung getestet. Für eine Deletionsmutante R133-P135 und eine Insertionsmutante S141-L140 konnte eine ungestörte Kapsidassemblierung nachgewiesen werden (KosCHEL et al., 1999). Dies lässt vermuten, dass offenbar nicht die Position der Mutationen an sich, sondern vielmehr die Funktion der Seitenkette an benannter Stelle einen Effekt auf die Kapsidassemblierung hat.

Die schwachen schmierenden Signale der Mutanten P129 und Y132 könnten bedeuten, dass die wenigen Kapside, die gebildet wurden, hochgradig instabil waren und sehr schnell wieder zerfielen. Eine Zufallsmutagenese mit kurzen Deletionen oder Insertionen zeigte, dass die meisten Mutationen N-terminal im Coreprotein auftraten. Bis auf eine Deletionsmutante R133 - P135 und eine Insertionsmutante S141 - L140 führten solche Mutationen C-terminal nach Position 80 nicht mehr zu assemblierten Kapsiden (KosCHEL et al., 1999).

Bereits 1995 konnte auch die Arbeitsgruppe Beames zeigen, dass 2 von 10 hergestellten Insertionsmutanten keine Kapside mehr assemblieren. Insertionen von drei Aminosäuren an Position I126 - R127 und von zwei Aminosäuren an Position A131 - Y132 führten zum Verlust der Kapsidbildung (BEAMES und LANFORD, 1995). 
Die durchgeführten Versuche, die durch die Literatur bestätigt werden, lassen somit den Schluss zu, dass der C-Terminus nicht nur an der Umhüllung des reifen Nukleokapsids beteiligt ist, sondern auch Funktionen bei der Assemblierung des Kapsids trägt.

\subsubsection{Grenzen der Interpretation}

Die in dieser Arbeit vorgestellten Ergebnisse basieren auf einer Phänotyp-GenotypBeurteilung. Hierbei wurde der Phänotyp einer Coremutante auf den Verlust der Seitenkettenaktivität an definierter Stelle bezogen, die insgesamt einmal pro Coreprotein, zweimal pro Coreproteindimer und 240 mal in einem Kapsid mit $\mathrm{T}=4$ Symmetrie vorkam. Die Veränderung jeder einzelnen Mutation führte bisweilen zu so deutlichen Konsequenzen, dass in 13 von 52 Fällen keine reifen Nukleokapside mehr gebildet wurden. Man muss allerdings annehmen, dass die Interaktion zwischen Hüllprotein und Kapsid über mehrere Aminosäuren sowohl seitens der Hüllproteine als auch seitens des Kapsids stattfindet, wie ja auch die große Anzahl umhüllungsinkompetenter Coremutanten bestätigt. Die Versuche erlauben zwar eine Aussage über eine Beteiligung einer Seitenkette an der Umhüllungsreaktion, sofern die Mutante als umhüllungsinkompetent identifiziert wurde, sie erlauben aber keine Aussagen über evtl. Mitbeteiligungen anderer Aminosäuren, deren Coremutanten als Wildtyp oder EPRnegativ eingestuft wurden. Es konnten mit diesem System somit wahrscheinlich längst nicht alle Aminosäuren identifiziert werden, die an einem Kontakt zu den Hüllproteinen während der Umhüllung beteiligt sein können. Die hier identifizierten Aminosäuren, die während der Umhüllung einen Kontakt zu den Hüllproteinen aufbauen, haben sicherlich die stärksten Bindungen, deren Verlust zum umhüllungsinkompetenten Phänotyp führt. Möglicherweise sind aber noch viel mehr Seitenketten an Kontakten beteiligt, die entweder schwächer sind, so dass eine alleinige Substitution keinen Effekt für einen veränderten Phänotyp hat, oder eine Substitution führt gleichzeitig zum Verlust der Bildung reifer Nukleokapside, weshalb sie nicht als solche erkannt werden konnte.

Des weiteren muss erwähnt werden, dass die Aminosäurekandidaten lediglich unter der Betrachtung einer direkten Interaktionsmöglichkeit mit den Hüllproteinen ausgewählt 
wurden. Sekundäre Effekte, die durch Substitution einer Aminosäure, insbesondere durch räumliche Verschiebungen auftreten können, sind nur schwer vorauszusehen und wurden bei der Auswahl der Kandidaten nicht berücksichtigt. Ein gutes Beispiel hierfür ist eine der häufigsten natürlich vorkommenden und gut charakterisierten Mutationen. Dies betrifft die Position 97, im Subtyp ayw handelt es sich um die Mutation I97L, im Subtyp adr um F97I (YUAN et al., 1999a; YUAN et al., 1999b; YUANG und SHIH, 2000; Le Pogam und Shih, 2002; SuK et al., 2002). Die benachbarten Positionen K95 und L96 waren in diesem Projekt interessante Kandidaten, da ihre Seitenketten an die Oberfläche des Kapsids nach außen zeigten. Sie zeigten beide einen umhüllungsinkompetenten Phänotyp, dem ein Funktionsverlust der Seitenkette zugeschrieben wurde. I97 (ayw) hingegen befindet sich im Inneren des 4-Helixbündels. Der Phänotyp wird als unreifer Sekretionsphänotyp beschrieben, der interessanterweise neben Virionen mit reifer partiell doppelsträngiger DNA offenbar auch Virionen mit unreifer einzelsträngiger DNA aufweist. Veränderungen, die durch diese Mutation insbesondere strukturell auf der Oberfläche des Kapsids hinsichtlich des Reifungssignals verursacht werden, können lediglich spekuliert werden. 


\subsection{Ansatz zur Infektion etablierter Leberzellkulturen mit HBV}

Viele Versuche der Hepatitis-B-Forschung unterliegen einer eingeschränkten Interpretation oder sind gar nicht erst durchführbar. Die Handhabung des menschlichen HBV in seiner natürlichen Wirtssituation gestaltet sich als äußerst aufwändig. Neben einer hohen Speziesspezifität besitzt das Virus auch eine Zelltypspezifität. Die Infektiösität ist auf primäre Hepatozyten des Menschen und hominider Primaten, wie Schimpansen und Tupaias beschränkt (ACS et al., 1987; WALTER et al., 1996).

Neben Tiermodellen HBV-verwandter Hepadnaviren, DHBV oder dem WHV nutzt die Erforschung der Molekularbiologie des humanen HBV fast ausschließlich Zellkulturen. Etablierte Leberzellkultursysteme, wie humane HuH7- oder HepG2-Zellen lassen sich mit viraler DNA enthaltenden Vektoren transfizieren oder auch transduzieren. Infektionen dieser Zelllinien mit HBV-Virionen hingegen sind nicht möglich. Erfolgreiche Infektionen, bei denen HepG2-Zellen mit HBV infiziert wurden (BCHINI et al., 1990), lassen sich nicht reproduzieren. Die in vitro Infektion mit HBV-Virionen blieb bislang primären Hepatozyten vorenthalten, die aus frischen Lebern gewonnen wurden. Die Arbeitsgruppe Gripon berichtete 1988 erstmals von der erfolgreichen Infektion menschlicher primärer Hepatozyten unter Verwendung von DMSO (GRIPON et al., 1988). Der Aufwand jedoch ist enorm groß. Zum einen ist die Disponibilität primärer humaner Hepatozyten äußerst beschränkt und zum anderen ist die Sensibilität primärer Zellen gegenüber einer HBV-Infektion nur bis 4 Tage nach Inkulturnahme vorhanden (TUTTLEMAN et al., 1986) und steht somit für nur wenige Versuche zur Verfügung. Es könnte z.B. sein, dass im Zuge der Ausdifferenzierung der primären Zellen durch Inkulturnahme das als HBV-Rezeptor genutzte Protein verloren geht.

Viele Ergebnisse des heutigen Wissensstandes der HBV-Forschung basieren auf Versuchen, die den HBV-verwandten Tiermodellen entstammen. Ein beliebtes Tiermodell stellt vor allem die Ente mit dem DHBV dar. Infektionsstudien mit primären Entenhepatozyten (PDH), aber auch im Tier selbst, sind aufgrund der kostengünstigen Haltung und einfachen Handhabung der Tiere erleichtert. Die ersten Infektionsversuche von PDHs gehen bereits in das Jahr 1986 zurück (TUTTLEMANN et al., 1986). Aber nicht 
alle Ergebnisse können uneingeschränkt auf das HBV-System übertragen werden, da es mitunter deutliche Unterschiede gibt, was beispielsweise Persistenz oder Pathogenität der beiden Virenarten anbelangt.

Als favorisierte Hypothese für den Verlust der Infizierbarkeit in Kultur genommener Hepatozyten gilt der Verlust des Rezeptors bzw. einer Rezeptorkomponente. Im DHBV-Modell wurde die Carboxypeptidase D (gp180) als ein Protein identifiziert, welches Infektiösität vermittelt (BREINER et al., 1998; ENG et al., 1998; ISHIKAWA et al., 1998). Sie gilt als Kandidat zumindest für eine DHBV-Rezeptorkomponente. In menschlichen Hepatomazellen vermittelt die Expression dieses Proteins zwar die Bindung und Aufnahme fluoreszenzmarkierter Virionen, führt jedoch nicht zu einer erfolgreichen Infektion der Zellen. (BREINER et al., 1998). Das Protein, welches vom HBV in humanen Leberzellen als Rezeptor verwendet wird, ist bisher nicht bekannt.

In Zellkulturen etablierte Transfektions- und Transduktionstechniken virale DNA enthaltender Vektoren stellen bisher die einzigen Möglichkeiten dar, HBV-Virionen in Zellkulturen zu produzieren und zu studieren. Jedoch erlauben diese Techniken nur einen eingeschränkten Blick vor allem in die frühen Prozesse des Vermehrungszyklus. Aufgrund der schlechten Dosisregulierung befindet sich nach Transfektion einer kompetenten Zelle immer so viel virale DNA in der Zelle, dass das Virus gleich mit späten Prozessen der Virusvermehrung beginnt. Für Untersuchungen der frühen Phase der Replikation des HBV wäre es vorteilhaft, für dieses Virus ein einfach zu handhabendes und reproduzierbares Infektionssystem zu entwickeln. So könnten die frühen Prozesse, solche wie Retransport des reifen Nukleokapsids zum Zellkern und Import des viralen Genoms in vivo, untersucht werden.

Die im ersten Teil der Arbeit beschriebenen Coremutanten wurden nach besonderen Merkmalen ausgewählt. Kandidaten waren solche Aminosäuren, deren Seitenketten eine besondere Exposition zur Kapsidoberfläche aufwiesen, um mit möglichst hoher Wahrscheinlichkeit solche Aminosäuren zu untersuchen, die einen Kontakt zu den außerhalb des Kapsids befindlichen Hüllproteinen etablieren konnten. Es wurde anschließend das Verhalten jeder einzelnen Coremutante hinsichtlich ihrer Umhüllungskompetenz untersucht. Neben der Untersuchung dieses Prozesses, der in der späten Phase der Infektion stattfindet, eignen sich die bereits hergestellten Coremutanten auch 
für die Untersuchung eines weiteren Prozesses, der vor allem in der frühen Phase der Infektion stattfindet. Bevor es in einer infizierten Zelle zur Produktion von Virionen kommt, muss ein bestimmter Grenzwert an viralen Genomkopien im Zellkern vorliegen. Das sich bildende reife Nukleokapsid wird somit nicht am ER umhüllt, sondern wird zunächst zurück zum Zellkern transportiert. Das Coreprotein besitzt hierfür ein C-terminal lokalisiertes Kernlokalisationssignal (NLS) (YEH et al., 1990), welches im phosphorylierten Zustand nach außen gerichtet eine Rekrutierung des Proteins in den Zellkern durch Kerntransportproteine wie Importin $\alpha$ und $\beta$ vermittelt (KANN et al., 1999). Dort angekommen, gelangt es durch die Kernpore in den Zellkern, zerfällt und entlässt die virale DNA in den Kern (PANTÉ und KANN, 2002)

Hierbei tritt das Nukleokapsid mit der Struktur des nuclear baskets in Kontakt. Es scheint eine Art Regulation dafür $\mathrm{zu}$ sorgen, dass lediglich reife Nukleokapside disassemblieren können und Genom sowie Coreproteine ins Karyoplasma entlassen (RABE et al., 2003). Möglicherweise treten hierbei auch Aminosäureseitenketten auf der Oberfläche in Kontakt mit Strukturen des nuclear basket. Von besonderem Interesse wäre $\mathrm{zu}$ untersuchen, ob die bereits hergestellten Coremutanten, die nach ähnlichen Gesichts-punkten ausgewählt wurden, auch eine Kartierung von Seitenketten zulassen, die für die Disassemblierung des Nukleokapsids und das Entlassen des viralen Genoms von Bedeutung sind. Es müsste hierfür ein System entwickelt werden, das die frühe Phase der HBV-Infektion in Hepatozyten sicherstellt.

Primäres Ziel war die Etablierung eines Infektionssystems für humane Hepatozytenkulturen mit dem HBV. Die Motivation dieses Projekts stützte sich auf die Hypothese, dass der Verlust der Infizierbarkeit humaner Hepatozyten mit dem Verlust einer Rezeptorvariante einhergeht. Möglicherweise muss das Virion lediglich an die Oberfläche der Zelle gebunden werden, um eine erfolgreiche Infektion der Zelle zu etablieren. Vielleicht könnte die Bindung des Virions auf die Zelloberfläche einen Endozytosemechanismus initiieren, so dass das Virion durch ein Endosom in die Zelle gelangt. Die Mechanismen der natürlichen Infektion des HBV sind noch ungeklärt, offensichtlich kommt es zur Fusion der Hülle mit der Zytoplasmamembran, und das Nukleokapsid wird in das Zytosol entlassen (QIAO et al., 1994). Andere virale Infektionssysteme, wie das Influenza-Virus oder das HIV (human immunodeficiency virus), führen auf ähnliche Weise zu einer erfolgreichen Infektion. Das HIV beispiels- 
weise infiziert eine CD4-positive Zelle, indem das Virus mit dem äußeren Teil des Glycoproteinkomplexes neben Korezeptorkomponenten an den CD4-Rezeptor bindet und die Hüllmembran des Virus mit der Zytoplasmamembran verschmilzt. Das Influenza-Virus, ein Vertreter aus der Familie der Orthomyxoviridae, wird nach Bindung an Oberflächenproteine zunächst in Endosomen in die Zelle aufgenommen. Dort kommt es dann nach Ansäuerung des Endosomens durch fusogene Aktivität des HA-Virus-Proteins zur Verschmelzung der Endosomenmembran mit der Virushülle, so dass anschließend das Nukleokapsid frei im Zytosol vorliegt und zum Zellkern transportiert werden kann. Um einen derartigen Weg der Infektion für das HBV zu testen, sollte eine einfache Imitation des HBV-Rezeptors hergestellt werden, welche in der Lage ist, HBV-Virionen an die Oberfläche einer zu infizierenden Zelle zu binden.

\subsubsection{Klonierung von MA18/7 und Herstellung des Rezeptorimitats}

Der künstliche Rezeptor musste vor allem zwei Kriterien genügen: Zum einen benötigt er eine hochaffine Bindungsdomäne für das HBV und zum anderen muss er auf der Zelloberfläche präsentiert werden, um das Virus auch erreichen zu können. Die Idee war, als Bindungsdomäne den monoklonalen Antikörper MA18/7 zu verwenden und eine Fusion mit einer Transmembrandomäne der B-Zell-Rezeptorform zu fusionieren. MA18/7 ging aus einer Immunisierung von fünf Mäusen mit aufgereinigten HBVPartikeln hervor (HEERMAN et al., 1984). Die Antigenität dieses Antikörpers ist auf die PräS1-Region des großen Hüllproteins gerichtet (SOMINSKAYA et al, 1992). Durch Präinkubation von Virionen ist MA18/7 in der Lage, eine Infektion zu unterbinden (PonTISSO et al., 1989).

Der Antikörper lag zu Beginn der Arbeit als Kryokultur einer Hybridomzelllinie vor, wie sie von der Arbeitsgruppe Gerlich 1984 hergestellt wurde. Die Zellen wurden in Kultur genommen und auf ihre Produktion des MA18/7-Antikörpers hin getestet. Mittels Polyacrylamid-Gel und Western-Blot konnten beide Ketten des Antikörpers spezifisch nachgewiesen werden (Daten nicht gezeigt). Die Zellen dienten dann als Ausgangsmaterial einer cDNA-Synthese mit anschließender PCR. Die cDNA-Synthese 
erfolgte unspezifisch über ein Poly-Thymin-Oligonukleotid, wodurch alle mit einem Poly-Adenin-Schwanz versehenen Gene gefischt werden konnten. Die anschließende spezifische PCR wurde mit einem speziell für das Amplifizieren von Immunglobulinen des Isotyps $\operatorname{IgG}_{1}$ Kappa entwickelten degenerierten Oligonukleotidsatz durchgeführt. Die Identifizierung der schweren Kette gestaltete sich als problemlos. Als leichte Kette wurde zunächst ein Produkt kloniert, welches zwar nach Sequenzierung und nach Abgleich mit der NCBI-Datenbank eine leichte Kette eines Antikörpers identifizieren ließ, sich aber nach ersten fehlgeschlagenen Expressionsversuchen als eine bereits beschriebene aberrante Kette der Hybridomzellinie herausstellte (CARROLL et al., 1988). Die eingesetzten degenerierten Primer basierten auf der hohen Homologie der

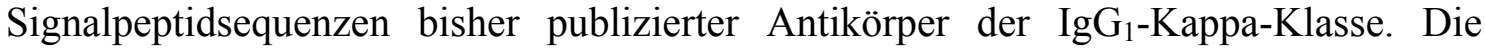
Klonierungsprodukte zeigten deshalb fehlende Nukleotide am 5'-Ende beider klonierter Ketten, die für ein funktionelles Protein mit Signalpeptid wiederhergestellt werden mussten. In der publizierten Originalsequenz von MA18/7 fehlten leider die Sequenzen der Signalpeptide. Ein Vergleich der in der NCBI-Datenbank publizierten $\operatorname{IgG}_{1}$-KappaAntikörper untereinander zeigte weitläufige Übereinstimmungen der Signalpeptide auf Proteinebene, so dass sich die Wiederherstellung der Signalpeptide einfach gestaltete. Es wurden N-terminal die jeweils fehlenden elf Aminosäuren im Gen durch PCR wiederhergestellt.

MA18/7 ist ein Immunglobulin des $\operatorname{IgG}_{1}$-Isotyps. Die leichte Kette ist eine KappaKette. Jede der fünf Immunglobulinisotypen (IgG, IgM, IgD, IgA und IgE) kann als sezernierte Form eines Antikörpers oder als transmembrane B-Zell-Rezeptorform vorliegen. In B-Zellen kommt es hierbei durch alternatives Splicen der schweren Kette $\mathrm{zu}$ einer C-terminalen Fusion einer hydrophoben Transmembrandomäne und einer kurzen zytosolischen Domäne (WALL und KUEHL, 1983). Wie bei den sezernierten Antikörpern kommt es auch bei den Membranformen aller Immunglobulin-Isotypen nach der Translation in die ER-Membran zur Ausbildung der klassischen Antikörperstruktur, bestehend aus zwei schweren und zwei leichten Ketten. Die Transmembrandomänen der Immunglobuline formen bereits im ER Heterodimere mit zwei zusätzlichen akzessorischen Proteinen Ig- $\alpha$ und $\mathrm{Ig}-\beta$, die für die meisten Isoformen für eine anschließende Oberflächenpräsentation notwendig sind (VENKITARAMAN et al., 1991). Die einzige Ausnahme bildet die membrane Form des IgD, welches auch ohne 
die akzessorischen Proteine Ig- $\alpha$ und Ig- $\beta$ in der Form eines Glycosyl-Phosphatidylinositol-verknüpften Proteins auf der Zelloberfläche erscheint (WIENANDS und RETH, 1992). Zur Oberflächenpräsentation des MA18/7-Antikörpers bot sich deshalb eine Fusion der Membrandomäne eines Immunglobulin-D-Isotyps an, da eine Koexpression der Ig- $\alpha$ - und Ig- $\beta$-Proteine noch aufwändiger gewesen wäre. Die Amplifizierung erfolgte durch Oligonukleotidsequenzen, die anhand der in der NCBI-Datenbank publizierten IgD-Transmembransequenzen publiziert sind. Nach erfolgreicher Klonierung wurde die 70 Aminosäuren umfassende Transmembrandomäne C-terminal an die schwere Kette des MA18/7-Antikörpers mittels PCR durch überlappende Oligonukleotide fusioniert. Sequenzanalysen zeigten auch, dass beim alternativen Splicen zur Herstellung der transmembranen Variante des IgD-Antikörpers mit dem Stopkodon zusätzlich die terminale Aminosäure Lysin entfernt wird. Dies fand auch Berücksichtigung bei der Fusion der Transmembrandomäne. Eine sekretorische Variante wurde mit dem terminalen Lysin und anschließendem Stopkodon hergestellt.

\subsubsection{Produktion und Oberflächenpräsentation des Rezeptorimitats}

Nach Herstellung der schweren und leichten Ketten wurde anschließend getestet, ob sich alle Konstrukte von MA18/7 in Zellkultur exprimieren lassen. Erste Versuche der Expressionen in einem eukaryotischen Expressionsvektor pCDNA3 waren ohne Erfolg (Daten nicht gezeigt). Es folgte eine Umklonierung der Ketten in das Plasmid pSBX24H unter Austausch des kleinen Hüllproteins (S). Für diese daraufhin in COS7Zellen getesteten Konstrukte pSV-LIgGHC9IgDTM und pSV-KappaLC8d konnte eine erfolgreiche Expression gezeigt werden. Die parallel hergestellte sekretorische Variante pSV-LIgGHC9* ließ sich weder im Medium noch im Zelllysat nachweisen. Da sich die sekretorische von der transmembranen Variante der schweren Kette nachweislich lediglich im C-Terminus unterschied, musste davon ausgegangen werden, dass die gewählte Konstruktion des C-Terminus die stabile Expression verhinderte. Von weiteren Versuchen zur Expression der sekretorischen Variante der schweren Kette wurde abgesehen, da die sekretorische Form des Proteins für das Projekt nicht notwendig war. 
Die Expression der transmembranen Variante der schweren Kette und der leichten Kette konnte sowohl einzeln als auch zusammen als Kotransfektion nachgewiesen werden (Abb. 24 auf Seite 106). Erwartungsgemäß konnte eine Expression der schweren Kette als Signal von ca. $50-55 \mathrm{kD}$ lediglich in den Zelllysaten aufgezeigt werden, was auf eine erfolgreiche Funktion der Transmembrandomäne hindeutete. Die leichte Kette war als Bande von ca. $28 \mathrm{kD} \mathrm{zu}$ erkennen und zeigte sich sowohl in den Proben nach Immunpräzipitation aus den Zelllysaten als auch aus den Medien. Die Fähigkeit zur Sekretion der leichten Kette zeigte, dass durch die Wiederherstellung des Signalpeptids letztendlich auch die Funktion dieser Domäne wiederhergestellt werden konnte. Vergleicht man die Intensität der Banden aus dem Zelllysat mit der der Medien, so fällt auf, dass man bereits eine Abhängigkeit der Sekretion der leichten Kette von der Präsenz der schweren Kette erkennen kann. Zeigt die einzelne Transfektion der leichten Kette noch ein deutlich schwächeres Signal im Zelllysat und ein kräftigeres Signal im Medium, so lässt die Kotransfektion beider Ketten ein deutlich stärkeres Signal der leichten Kette im Zelllysat und ein etwas geringeres Signal im Medium erkennen. Dies bedeutet, dass der überwiegende Anteil der exprimierten leichten Kette aufgrund des Signalpeptids ins Medium sekretiert wird. Bei Kotransfektion mit der membranständigen schweren Kette jedoch wird ein größerer Teil des Proteins in bzw. an den Zellen zurückgehalten. Dieses Zurückhalten der leichten Kette durch Koexpression der schweren Kette ließ vermuten, dass sich tatsächlich eine funktionelle Antikörperstruktur aus membranständiger schwerer und leichter Kette gebildet hatte.

Durch nachfolgende Immunfluoreszenzversuche konnte auch eine Oberflächenpräsentation des MA18/7-Antikörpers auf HuH7- und COS7-Zellen bestätigt werden. Hierbei wurden nach Kotransfektion beider Ketten zum einen permeabilisierte Zellen und zum anderen nichtpermeabilisierte Zellen mit dem anti-Maus-Cy2-markierten Konjugat markiert. Die Färbungen der permeabilisierten Zellen zeigte eine erfolgreiche Produktion von MA18/7. Die nichtpermeabilisierten Zellen konnten von dem Konjugat lediglich von außen erreicht werden, wie auch der Kontrollversuch sicherstellte. Die Färbungen der Zellmembranen dieser Zellen zeigten eindeutig eine Membranlokalisation des MA18/7-Antikörpers mit einer nach außen gerichteten Orientierung. Das heißt, die Signalpeptide beider Ketten sowie die Transmembrandomäne erfüllen 
ihre Funktionen, der Antikörper scheint richtig zu assemblieren und befindet sich membranlokalisiert auf der Außenseite der Zellmembran.

\subsubsection{Bindung und Aufnahme von HBV-Virionen}

Nachdem die Expression und Lokalisation des MA18/7-Antikörpers bestätigt wurde, sollte versucht werden, die Funktionalität des Antikörpers auf der Zelloberfläche nachzuweisen. Dies geschah durch Bindungsversuche mit HBV-Filamenten und Virionen. In einem ersten Experiment wurde versucht, optisch mittels Immunfluoreszenz die Bindung von HBsAg nachzuweisen. Hierfür wurden MA18/7-kotransfizierte Zellen nach Fixierung zunächst mit einem hochtitrigen HBV-Patientenserum inkubiert. Die möglicherweise gebundenen Filamente und Virionen sollten anschließend mit einem Anti-HBs-Antikörper inkubiert werden, der wiederum das Antigen für das verwendete Cy3-markierte Konjugat darstellte. Die Ergebnisse nach konfokaler Mikroskopie sind leider nicht so deutlich gewesen, wie die zuvor beschriebenen Immunfluoreszenzen des Nachweises zur Lokalisation des Antikörpers. Im Vergleich zur Negativkontrolle konnten nur spärliche Signale verzeichnet werden, die eine eindeutige Interpretation dieses Versuchs nicht zuließen.

Als weiterer Versuch wurde ein PCR-Nachweis nach Inkubation MA18/7-kotransfizierter Zellen mit Virionen eines hochtitrigen Patientenserums durchgeführt. Hier zeigte sich, dass tatsächlich die Expression des MA18/7-Antikörpers im Vergleich zur mocktransfizierten Kontrolle eine spezifische Bindung von HBV-Virionen vermitteln konnte. Die unspezifische Bindung von HBV-Virionen an die mock-transfizierten Negativkontrollen konnte bis zu einer Verdünnung von $10^{-2}$ (HuH7) bzw. 10 ${ }^{-3}$ (COS7) festgelegt werden. Bei einer Verdünnung von $10^{-4}$ und $10^{-5}$ war die Probe deutlich negativ. Die Proben der MA18/7-transfizierten Zellen wurden bis Verdünnungen von $10^{-5}$ nahezu unverändert stark nachgewiesen, was mindestens eine 100 bis 1000-fach stärkere Bindung, vermittelt durch MA18/7-Expression, bedeutet. Die im Vergleich zu den höheren Verdünnungsstufen schwachen Signale der $10^{-2}$-Verdünnungen muss auf den hohen Gesamt-DNA-Gehalt der Proben rückzuführen sein, welche zu suboptimalen 
Bedingungen der PCR-Nachweisreaktion führten. Durch diesen Versuch konnte eindeutig gezeigt werden, dass HBV-Virionen MA18/7-vermittelt auf der Zelloberfläche spezifisch binden.

\subsubsection{Infektionsversuch}

Eigentliches Ziel dieses Projekts war die MA18/7-vermittelte Infektion einer Hepatoblastomzelllinie, wie HuH7 oder HepG2, mit HBV. Der Erfolg einer Infektion wurde über die diagnostischen Marker HBsAg und $\mathrm{HBeAg}$ verfolgt, die bei einer Virusproduktion ins Medium sezerniert werden. In keinem der beschriebenen Versuchsansätze konnte über einen Zeitraum von 10 Tagen nach Viruskontakt einer der beiden charakteristischen Marker einer erfolgreichen HBV-Infektion beobachtet werden.

Hierfür können unterschiedliche Ursachen verantwortlich sein. Möglicherweise wird das Virus zwar auf der Oberfläche gebunden, es kommt jedoch nicht zu einer Aufnahme des Virus. Vielleicht konnte aber auch die Ursprungsmotivation, das Virus in die Zelle $\mathrm{zu}$ bekommen, tatsächlich umgesetzt werden. Versuche hierzu lieferten keine eindeutigen Ergebnisse (Daten nicht gezeigt). Das gebundene HBV-Virion könnte beispielsweise in einem Endosom eingeschlossen in der Zelle vorliegen, gelangt aber nicht aus diesem Kompartiment als Nukleokapsid ins Zytosol. Endosomen werden in ihrem Verlauf durch die Zelle angesäuert. Dies könnte auch zu einer Zerstörung oder Beschädigung des Virions führen. Selbst wenn das Virion den Weg in das Zytosol gefunden hat, müssten auch alle anderen Schritte funktionieren, die letztendlich zu einem Import des HBV-Genoms in den Zellkern führen.

Ein durch MA18/7 vermitteltes in das Zytosol vorgedrungene Virion muss also noch in der Lage sein, alle Funktionen eines reifen Nukleokapsids zu erfüllen. Kritische Schritte sind die Präsentation des Kernlokalisationssignals und der Disassemblierungsprozess im nuclear basket. Man kann beispielsweise bei transgenen Mäusen, die ein HBV-Genom tragen und Viren produzieren, keine Produktion von ccc-DNA im Zellkern finden (GUIDOTTI et al., 1994). Offenbar kommt es auch hier nicht zu einem Import von Nukleokapsiden in den Zellkern. 


\section{ZUSAMMENFASSUNG}

Es wurde von der Arbeitshypothese ausgegangen, dass die Umhüllung des cytosolischen HBV-Nukleokapsids durch dessen direkte Interaktion mit transmembranen Hüllproteinen bewirkt wird. Um Interaktionsdomänen auf dem Kapsid zu kartieren, wurden 52 einzelne Alanin-Substitutionen im Coreprotein hergestellt, die einen Großteil der Kapsidoberfläche abdecken. Alle Coremutanten wurden hinsichtlich Kapsidbildung, Genomsynthese und Umhüllungskompetenz getestet. Erwartungsgemäß hatte der überwiegende Anteil der Mutationen (28) einen Wildtyp-Phänotyp. Bei elf Mutanten zeigte sich der gesuchte Phänotyp: Sie waren zwar noch in der Lage, cytoplasmatische DNA-haltige Nukleokapside zu bilden, wurden jedoch nicht mehr als Bestandteil von Virionen ins Medium sezerniert. 13 Mutationen verhinderten oder reduzierten sehr stark die Bildung detektierbarer Nukleokapside. Die elf umhüllungsdefizienten Mutationen waren in zwei Klustern auf der Oberfläche des Nukleokapsids lokalisiert. Diese Regionen stellen Kandidaten für die gesuchten Interaktionsdomänen dar.

Für den Versuch, eine HBV-infizierbare Leberzelllinie zu generieren, wurden cDNAs für den monoklonalen Antikörper MA18/7 aus einer Hybridomzelllinie durch mRNAIsolierung und reverser Transkription kloniert und die schwere Kette mit einer Sequenz für die IgD-Transmembrandomäne fusioniert. Nach Transfektion der transmembranen schweren und der leichten Kette in einem geeigneten Expressionsvektor wurde gezeigt, dass MA18/7 in COS7- und HuH7-Zellen exprimiert wird, dass der Antikörper in der Zytoplasmamembran lokalisiert ist, dass er nach außen gerichtet und in der Lage war, HBV-Virionen auf der Zelloberfläche zu binden. Eine erfolgreiche Infektion konnte durch Bestimmung von $\mathrm{HBsAg}$ und $\mathrm{HBeAg}$ im Zellkulturüberstand über einen Zeitraum von zehn Tagen nach Virusinkubation nicht beobachtet werden. 


\section{LITERATURVERZEICHNIS}

Acs, G., Sells, M.A., Purcell, R.H., Price, P., Engle, R., Shapiro, M. und H. Popper (1987) "Hepatitis B virus produced by transfected HepG2 cells causes hepatitis in chimpanzees" Proc. Natl. Acad. Sci. USA 84: 4641-4644

Addison, W.R., K.A. Walters, W.W.S. Wong, J.S. Wilson, D. Madej, L.D.Jewell und D.L.J. Tyrrell (2002) "Half-life of the duck hepatitis B virus covalently closed circular DNA pool in vivo following inhibition of viral replication" J. Virol. 76: 6356-6363

Aden, D.P., Fogel, A., Plotkin, S., Damjanov, I. und B.B. Knowless (1979) "Controlled synthesis of HBsAg in a differentiated liver carcinoma-derived cell line" Nature 282: 615-618

Bartenschlager, R., Junker-Niepmann, M. und H. Schaller (1990) "The P gene product of hepatitis B virus is required as a structural component for genomic RNA encapsidation" J. Virol. 64: 5342-5332

Bchini, R., Capel, F., Dauguet, C., Dubanchet, S. und M.A. Petit (1990) "In vitro infection of human hepatoma (HepG2) cells with hepatitis B virus" J. Virol. 64: $3025-3032$

Beames, B. und R.E. Lanford (1995) "Insertions within the hepatitis B virus capsid protein influence capsid formation and RNA encapsidation." J. Virol. 69: 6833-8

Beasley, R.P., Hwang, L.Y., Lin, C.C. und C.S. Chien (1981) "Hepatocellular carcinom and hepatitis B virus. A prospective study of 22707 men in Taiwan" Lancet 2: 1129-1133

Birnbaum, F. und M. Nassal (1990) "Hepatitis B virus nucleocapsid assembly: primary structure requirements in the core protein" J. Virol. 64: 3319-3330

Birnboim, C. und P. Doly (1979) "A rapid alkaline extraction procedur for screening recombinant plasmid DNA" Nucl. Acids. Res. 7: 1513-1515 
Blum, H.E., Haase, A.T., Harris, J.D., Walker, D. und G.N. Vyas (1984) “Asymmetric replication of hepatitis B virus DNA in human liver: demonstration of cytoplasmic minus-strand DNA by dot blot analysis and in situ hybridization" Virology 139: 87-96

Blum, H.E., Zhang, Z.S., Galun, E., Weizsäcker, F., Garner, B., Liang, T.J. und J.R. Wands (1992) "Hepatitis B virus X protein is not central to the viral life cycle in vitro" J. Virol. 66: 1223-1227

Blumberg, B.S., Alter, H.J., Visnich, S. (1965) "A "new" antigen in leukemia sera" JAMA 191, 541

Böttcher, B., Wynne, S.A. und R.A. Crowther (1997) "Determination of the fold of the core protein of hepatitis B virus by electron cryomicroscopy" Nature 386: 88-91

Böttcher, B., Tsuji, N., Takahashi, H., Dyson, M.R., Zhao, S., Crowther, R.A. und K. Murray (1998) "Peptides that block hepatitis B virus assembly: analysis by cryomicroscopy, mutagenesis and transfection" EMBO J. 17: 6839-6845

Borisova, G., Arya, B., Dislers, A., Borschukova, O., Tsibinogin, V., Skrastina, D., Eldarov, M.A., Pumpens P., Skryabin, K.G. und E. Grens (1993) "Hybrid hepatitis B virus nucleocapsid bearing an immuno-dominant region from hepatitis B virus surface antigen" J. Virol. 67: 3696-3701

Breiner K. M., Urban S. und H. Schaller (1998) "Carboxypeptidase D (gp180), a Golgi resistant protein, functions in the attachment and entry of avian hepatitis B viruses" J. Virol. 72: 8098-8104

Bruss, V. und D. Ganem (1991) "The role of envelope protein in hepatitis B virus assembly" Proc. Natl. Acad. Sci. USA 88: 1059-1063

Bruss V., L. Xuanyoung, R. Thomssen und W.H. Gerlich (1994) "Post-translational alterations in transmembrane topology of the hepatitis B virus large envelope protein" EMBO J. 13: 2273-2279

Bruss V., E. Gerhardt, K. Vieluf und G. Wunderlich (1996) "Functions of the large hepatitis B virus surface protein in viral particle morphogenesis" Intervirology 39: $23-31$ 
Bruss, V. (1997) "A short linear sequenz in the pre-S domain of the large hepatitis B virus envelope protein required for virion formation" J. Virol. 71: 9350-9357

Burnette, W.N. (1981) ““Western Blotting”: Elektrophoretic transfer of proteins from sodium dodecyl sulfate-polyacrylamide gels to unmodified nitrocellulose and radiographic detection with antibody and radioiodinated protein" Anal. Biochem. 112: 195-203

Carroll W. L., Mendel E. und S. Levy (1988) "Hybridoma fusion cell lines contain an aberant kappa transcript" Mol. Immun. 25: 911-995

Chang, L.J., Hirsch, R.C., Ganem, D. und H.E. Varmus (1990) "Effects of insertional and point mutations on the functions of the duck hepatitis B virus polymerase" J. Virol. 64: $5553-5558$

Cohen, B.J. und J.E. Richmond (1982) "Electron microscopy of hepatitis B core antigen synthesized in E. coli" Nature 296: 677-678

Conway, J.F., Cheng, N., Zlotnik, A., Wingfield, P.T., Stahl, S.J. und A.C. Steven (1997) "Visualization of a 4-helix bundle in the hepatitis B virus capsid by cryoelectron microscopy" Nature 386: 91-94

Crowther, R.A., Kiselev, N.A., Böttcher, J.A., Berriman, J.A., Borisova, G.P., Ose, V. und P. Pumpens (1994) "Three-dimensional structure of hepatitis B virus core particles determined by electron cryomicroscopy" Cell 77: 943-950

Dyson M.R. und K. Murray (1995) "Selection of peptide inhibitors of interactions involved in complex protein assemblies: association of the core and surface antigens of hepatitis B virus" Proc. Natl. Acad. Sci. USA 92: 2194-2198

Eble B. E., Lingappa V. R. und D. Ganem, (1986) "Hepatitis B surface antigen: an unusual secreted protein initially synthesized as a transmembrane polypeptide" Mol. Cell. Biol. 6: 1454.

Eble B. E., MacRae, D.R., Lingappa V. R. und D. Ganem, (1987) "Multiple topogenic sequences determin the transmembrane orientation of hepatitis B surface antigen" Mol. Cell. Biol 7: 2591-3601 
Eble B. E., Lingappa V. R. und D. Ganem, (1990) "The N-terminal (preS2) domain of hepatitis B virus surface glycoprotein is translocated across membranes by downstream signal sequences" J. Virol. 64: 1414-1419

Eng F. J., Novikova E. G., Kuroki K., Ganem D. und L.D. Fricker (1998) “gp180, a protein that binds duck hepatits B virus particles, has metallocarboxypeptidase D like enzymatic activity" J. Biol. Chem. 273: 8382-8388

Ganem, D. und H.E. Varmus (1987) "The molecular biology of the hepatitis B viruses" Ann. Rev. Biochem. 56: 761-766

Gallina A., Bonelli, G., Zentilin, I., Rindi, G., Muttini, M. und G. Milanesi (1989) "A recombinant hepatitis B core antigen polypeptide with the protamine-like domain deleted self-assembles into capsid particles but fails to bind nucleic acids" J. Virol. 63: $4645-4652$

Gerelsaikhan, T., Tavis, J.E. und V. Bruss (1996) "Hepatitis B virus nucleocapsid envelopment does not occur without genomic DNA synthesis" J. Virol. 70: 4269-4274

Gerlich, W.H. und W.S. Robinson (1980) "Hepatitis B virus contains protein attached to the 5'-terminus of its complete DNA strand" Cell 21: 801-809

Gluzmann, Y. (1981) "SV40 transformed simian cells support the replication of early SV40 mutants" Cell 23: 175-182

Gripon, P., Diot, C., Theze, N., Fourel, O., Loreal, O., Brechot, C. und C. GuguenGuillouzo (1988) "Hepatitis B virus infection of adult human hepatocytes cultured in the presence of dimethyl sulfoxid" J. Virol. 62: 4136-4143

Gripon, P., C. Diot und C. Guguen-Guillouzo (1993) "Reproducible high level infection of cultured adult human hepatocytes by hepatitis B virus: effect of polyethylene glycol on adsorption and penetration" Virology 192: 534-540

Guidotti, L.G., Martinez, V., Loh, Y.T., Rogler, C.E. und F.V. Chisari (1994) "Hepatitis B virus nucleocapsid particles do not cross the hepatocyte nuclear membrane in transgenic mice" J. Virol. 68: 5469-5475

Hanahan, D. (1983) "Studies of transformation of Escherichia coli with plasmids" J. Mol. Biol. 166: 557-580 
Hatton, T., Zhou, S. und D.N. Standring (1992) "RNA- and DNA-binding activities in hepatitis B virus capsid protein: a model for their roles in viral replication" J. Virol. 66: $5232-5241$

Heermann, K.H., Goldmann, U., Schwartz, W., Seyffarth, T., Baumgarten, H. und W.H. Gerlich (1984) "Large surface proteins of hepatitis B virus containing the pre-S sequence" J. Virol 52: 396-402

Howe, A. und D. Tyrell (1996) "Duck hepatitis B polymerase acts as a suppressor of core protein translation" J. Virol. 70: 5035-5042

Huang, M.J. und J. Summers (1991) "Infection initiated by the RNA pregenome of a DNA virus" J. Virol. 65: 5435-5439

Hruska, J.F., Clayton, D.A., Rubenstein, J.L.R. und W.S. Robinson (1977) "Structure of hepatitis B Dane particle DNA before and after the Dane particle DNA polymerase reaction" J. Virol. 21: 666-672.

Ishikawa T., Murakami K., Kido Y., Ohnishi S., Yazaki Y., Harada F und K. Kuroki (1998) "Cloning functional expression, and chromosomal localization of the human and mouse gp180 carboxypeptidase D like enzyme" Gene 215: 361-370

Junker-Niepmann, M., Bartenschlager, R. und H. Schaller (1990) “A short cis-acting sequence is required for hepatitis $\mathrm{B}$ virus pregenome encapsidation and sufficient for packaging of foreign RNA" EMBO J. 9: 3389-3396

Kann, M. und W.H. Gerlich (1994) "Effect of core-protein phosphorylation by protein kinase $\mathrm{C}$ on encapsidation of RNA within core particles of hepatitis B virus" J. Virol. 68: $7993-8000$

Kann, M., Sodeik, B., Vlachou, A., Gerlich, W.H. und A. Helenius (1999) "Phosphorylation-dependent binding of hepatitis B virus core particles to the nuclear pore complex" J. Cell. Biol. 145: 45-55

Kaplan, P.M., Greenman, R.L., Gerin, J.L., Purcell, R.H. und W.S. Robinson (1973) "DNA polymerase associated with human hepatitis B antigen" J. Virol. 12: 995-1005

Kekule, A.S., Lauer, U., Weiss, L., Luber, B. und P.H. Hofschneider (1993) "Hepatitis B virus transactivator HBx uses a tumour promotor signalling pathway" Nature 361: $742-745$ 
Kenney, J.M., von Bonsdorff, C-H., Nassal, M. und S.D. Fuller (1995) "Conformational flexibility and evolutionary conservation in the hepatitis B virus core structure" Structure 3: 1009-1019

Köck, J. und H.J. Schlicht (1993) "Analysis of the earliest steps of hepadnavirus replication: genome repair after infectious entry into hepatocytes does not depend on viral polymerase activity" J. Virol. 67: 4867-4874

König, S., Beterams, G. und M. Nassal (1998) "Mapping of homologous interaction sites in the hepatitis B virus core protein" J. Virol. 72: 4997-5005

Koschel, M., Thomssen, R. und V. Bruss (1999) "Extensive mutagenesis of the hepatitis B virus core gene and mapping of mutations that allow capsid formation" J. Virol. 73: $2153-2160$

Koschel, M., Oed, D., Gerelsaikhan, T., Thomssen, R. und V. Bruss (2000) "Hepatitis B virus core gene mutations which block nucleocapsid envelopment" J. Virol. 74: 1-7

Kozak, M. (1986) "Point mutations define a sequence flanking the AUG initiator codon that modulates translation by eukaryotic ribosomes" Cell 44: 283-392

Laemmli, U.K. (1970) "Cleavage of structural proteins during assembly of the head of bacteriophage T4" Nature 227: 680-685

Lanford, R.E., Chavez, D., Brasky, K.M., Burns III, R.B. und R. Rico-Hesse (1998) "Isolation of a hepadnavirus from the woolly monkey, a New World primate" Proc. Natl. Acad. Sci. USA 95: 5757-5761

Lanford, R.E. und L. Notvall (1990) "Expression of hepatitis B virus core and precore antigens in insect cells and characterization of a core-associated kinase activity" Virology 176: 222-233

Lenhoff, R.J. und J. Summers (1994) "Coordinate regulation of replication and virus assembly by the large envelope protein of an avian hepadnavirus" J. Virol. 68: $4565-4571$

Le Pogam, S., Yuan, T.T., Sahu, G.K., Chatterjee, S. und C. Shih (2000) "Low-level secretion of human hepatitis B virus virions caused by two independent, naturally occuring mutations (P5T and L60V) in the capsid protein” J. Virol. 74: 9099-9105 
Le Pogam, S. und C. Shih (2002) "Influence of a putative intermolecular interaction between core and the preS1 domain of the large envelope protein on hepatitis B virus secretion" J. Virol. 76: 6510-6517

Le Seyec, J., Chouteau, P., Cannie, I., Guguen-Guillouzo, C. und P. Gripon (1999) "Infection process of the hepatitis B virus depends on the presence of a defined sequence in the pre-S1 domain" J. Virol. 73: 2052-2057

Liébecq, C. (1978) "Biochemical nomenclature and related documents. International Union for Biochemistry" London: The Biochemical Society

Lien, J.-M., Aldrich, C.E. und W.S. Mason (1986) "Evidence that the capped oligoribonucleotide is the primer for duck hepatitis B virus plus-strand DNA synthesis" J. Virol. 57: 229-236

Lien, J.-M., Petcu, D.J., Aldrich, C.E. und W.S. Mason (1987) "Initiation and termination of duck hepatitis B virus DNA synthesis during virus maturation" J. Virol. 61: $3832-3840$

Loeb, D.D., Hirsch, R.C. und D. Ganem (1991) "Sequence-independent RNA cleavages generate the primer for plus-strand synthesis of hepatitis B viruses: implications for other reverse transcribing elements" EMBO J. 10: 3533-3540

Löffler-Mary, H., Dumortier, J., Klentsch-Zimmer, C. und R. Prange (2000) "Hepatitis $\mathrm{B}$ virus assembly is sensitive to changes in the cytosolic S loop of the envelope proteins" Virology 270: 358-367

Marion, P.L., Oshiro, L.S., Regnery, D.C., Scullard, G.H. und W.S. Robinson (1980) "A virus in Beechey ground squirrels that is related to hepatitis B virus of humans" Proc. Natl. Acad. Sci. USA 77: 2941-2945

Mason, W.S., Seal, G. und J. Summers (1980) "Virus of Pekin ducks with structural and biological relatedness to human hepatitis B virus.“ J. Virol. 36: 829-836

McAleer W.J., Buynak E.B., Maigetter R.Z., Wapler D.E., Miller W.J. und M.R. Hillerman (1984) "Human hepatitis B vaccine from recombinant yeast" Nature 307: $178-180$ 
Nakabayashi, H., Taketa, K., Miyano, K., Yamane, T. und J. Sato. (1982) "Growth of human hepatoma cell lines with differentiated functions in chemically defined medium" Cancer Res. 42: 3858-3863

Nassal, M., Junker-Niepmann, M. und H. Schaller (1990) "Translation inactivation of RNA function: discrimination against a subset of genomic transcripts during HBV nucleocapsid assembly" Cell 63: 1357-1363

Nassal., M. (1992a) "The arginine rich domain of the hepatitis B virus core protein is required for pregenome encapsidation and productive viral positive-strand DNA synthesis but not for virus assembly" J. Virol. 66: 4107-4116

Nassal, M. (1992b) "Conserved cysteines of the hepatitis B virus core protein are not required for assembly of replication-competent core particles nor for their envelopment" Virology 190: 499-505

Panté N. und M. Kann (2002) "Nuclear pore complex is able to transport macromolecules with diameters of 39 nm" Mol Biol Cell 13: 425-434

Perlman, D. und J. Hu (2003) "Duck hepatitis B virus secretion requires a doublestranded DNA genome" J. Virol. 77: 2287-2294

Peterson, D.L. (1981) "Isolation and characterization of the major protein and glycoprotein of hepatitis B surface antigen" J. Biol. Chem. 256: 6975-6983

Petit, M.A. und J. Pillot (1985) "HBc and HBe antigenicity and DNA binding affinity of major core protein P22 in hepatitis B virus core particles isolated from the cytoplasm of human liver cells" J. Virol. 53: 543-551

Pontisso, P., Ruvoletto, M.G., Gerlich, W.H., Heermann, K.H., Bardini, R. und A. Alberti (1989) "Identification of an attachment site for human liver plasma membranes on hepatitis B virus particles" Virology 173: 522-530

Pugh, J.C., Zweidler, A. und J. Summers (1989) "Characterization of the major duck hepatitis B virus core particle protein” J. Virol. 63: 1371-1376 
Pushko, P., Sälberg, M., Borisova, G., Ruden, U., Bichko, V., Wahren, B., Pumpens, P. und L. Magnius (1994) "Identification of hepatitis B virus core protein regions exposed or internalized at the surface of HBsAg particles by scanning with monoclonal antibodies" Virology 202: 912-920

Qiao M., Macnaughton T.B. und E.J. Gowans (1994) "Adsorption and penetration of hepatitis B virus in an nonpermissive cell line" Virology 201: 356-363

Rabe, B., Vlachou, A., Panté, N., Helenius, A. und M. Kann (2003) "Nuclear import of hepatitis B virus capsids and release of the viral genome" PNAS 100: 9849-9854

Radziwill, G., Tucker, W. und H. Schaller (1990) "Mutational analysis of the hepatitis B virus P gene product: Domain structure and RNaseH activity" J. Virol. 64: 613-620

Robinson, W.S., Clayton, D.A. und R.L. Greenman (1974) "DNA of human hepatitis B virus candidate" J. Virol. 14: 384-391

Rossner, M.T. (1992) "Review: Hepatitis B virus X-gene product: a promiscuous transcriptional activator" J. Med. Virol. 36: 101-117

Saiki, R.K., Scharf, S., Faloona, F., Mullis, K.B., Horn, G.T., Erlich, H.A. und N. Arnheim (1985) "Enzymatic amplification of $\beta$ globin genomic sequences and restriction site analysis for diagnostic of sickle cell anemia" Science 230: 1350-1354

Salfeld, J., Pfaff, E., Noah, M. und H. Schaller (1989) "Antigenic determinants and functional domains in core antigen and e antigen from hepatitis B virus" J. Virol. 63: 798-808

Sällberg, M., Ruden, U., Magnius, L.O., Harthus, H.P., Noah, M. und B. Wahren (1991) "Characterisation of a linear binding site for a monoclonal antibody to hepatitis B core antigen" J. Med. Virol 33: 248-252

Sanger, F., Nicklen, S., Coulson, A.R. (1977) "DNA sequencing with chain-terminating inhibitors" Proc. Natl. Acad. Sci. USA 74: 5463-5467

Sattler, F. und W.F. Robinson (1979) "Hepatitis B viral DNA molecules have cohesive ends" J. Virol. 32: 226-232 
Schaller H und M. Fischer (1991) "Transcriptional control of hepadnavirus gene expression" Curr. Top. Microbiol. Immunol. 168: 21-39

Schlicht H.J. und H. Schaller (1989) "Analysis of hepatitis B virus gene functions in tissue cultures and in vivo" Curr. Top. Microbiol. Immunol. 144: 253-263

Seifer, M., Zhou, S. und D.N. Standring (1993) “A micromolar pool of antigenically distinct precursors is required to initiate cooperative assembly of hepatitis B virus capsids in Xenopus oocytes" J. Virol. 67: 249-257

Sominskaya, I., Pushko, P., Dreilina, D., Kozlovskaya, T. und P. Pumpen (1992) "Determination of the minimal length of preS1 epitope recognized by a monoclonal antibody which inhibits attachment of hepatitis B virus to hepatocytes" Med. Microbiol. Immunol.181: 215-226

Southern, E.M. (1975) "Detection of specific sequences among DNA fragments separated by gel electrophoreses" J. Mol. Biol. 98: 503-517

Sprengel, R., Kaleta, E.F. und H. Will (1988) "Isolation and characterization of a hepatitis B virus endemic in herons" J. Virol. 62: 3832-3839

Stibbe, W. und W.H. Gerlich (1982) "Variable protein composition of hepatitis B surface antigen from different donors" Virology 123: 436-442

Stirk, H.J., Thornton, J.M. und C.R. Howard (1992) “A topological model for hepatitis B surface antigen" Intervirology 33: 148-158

Studier, F.W. (1973) "Analysis of bacteriophage T7 early RNAs and proteins on slab gel” J. Mol. Biol. 79: 237-248

Suk, F.M., Lin, M.H., Newman, M., Pan, S., Chen, S.H., Liu, J.D. und C. Shih (2002) "Replication advantage and host factor-independent phenotypes attributable to a common naturally occuring capsid mutation (I97L) in human hepatitis B virus" J. Virol. 76: 12069-12077

Summers, J. und W.S. Mason (1982) "Replication of the genome of a hepatitis B-like virus by reverse transcription of an RNA intermediate" Cell 29: 403-415 
Summers, J., Smolec, J.M. und R. Snyder (1978) "A virus similar to human hepatitis B virus associated with hepatitis and hepatoma in woodchucks" Proc. Natl. Acad. Sci. USA 75: 4533-4537

Tiollais, P., Charnay, P. und G. Vyas (1981) "Biology of hepatitis B virus" Science 213: 406-411

Tiollais, P., Pourcel, C. und A. Dejean (1985) "The hepatitis B virus" Nature 317: 489-495

Tuttleman, J. S., C. Pourcel and J. Summers (1986) "Formation of the pool of covalently cloesed circular viral DNA in hepadnavirus-infected cells" Cell 47: 451-460

Valenzuela, P., Quiroga, M., Zalvidar, J., Gray, P. und W. Ruttner (1980) "The nucleotide sequence of the hepatitis B viral genome and the identification of the major viral genes" Animal Virus Genetics, Hrsg. Fields, B.N., Jaenisch, R. und C.F. Fox; Academic Press, New York, 57-70

Venkitaraman, A.R., Williams, G.T., Dariavach, P. und M.S. Neuberger (1991) "The B-cell antigen receptor of the five immunoglobulin classes" Nature 352: 777-781

Wall, R. und M. Kuehl (1983) "Biosynthesis and regulation of immunoglobulins" Annu. Rev. Immunol. 1: 393-422

Walter, E., Keist, R., Niederost, B., Pult, I. und H.E. Blume (1996) "Hepatitis B virus infection of tupaia hepatocytes in vitro and in vivo" Hepatology 24: 1-5

Wei, Y., Tavis, J.E. und D. Ganem (1996) "Relationship between viral DNA synthesis and virion envelopment in hepatitis B virus" J. Virol. 70: 6455-6458

Wienands, J., und M. Reth (1992) "Glycosyl-phosphatidylinositol linkage as a mechanism for cell-surface expression of immunoglobulin D" Nature 356: 246-248

Wingfield, P.T., Stahl, S.J., Williams, R.W. und A.C. Steven (1995) "Hepatitis core antigen produced in Escherichia coli: subunit composition, conformational analysis, and in vitro capsid assembly" Biochemistry 34: 4919-4932

Wynne, S.A., Crowther, R.A. und A.G.W. Leslie (1999) "The crystal structure of the human hepatitis B virus capsid" Mol. Cell 3: 771-780 
Yeh, C T., Y. F. Liaw and J. H. Ou (1990) "The argini-rich domain of hepatitis B virus precore and core proteins contains a signal for nuclear transport" J. Virol. 64: $6141-6147$

Yu, M. und J. Summers (1991) "A domain of the hepadnavirus capsid protein is specifically required for DNA maturation and virus assembly" J. Virol. 65: 2511-2517

Yu, M. und J. Summers (1994) "Phosphorylation of the duck hepatitis virus capsid protein associated with conformational changes in the C terminus" J. Virol. 68: 2965-2969

Yuan, T.T.,. Sahu, G.K., Whitehead, W.W., Greenberg, R. und C. Shih (1999a) "The mechanism of an immature secretion phenotype of an highlyfrequent naturally occuring missense mutation at codon 97 of human hepatitis B virus core antigen" J. Virol. 73: $5731-5740$

Yuan, T.T., Tai, P.C. und C. Shih (1999b) "Subtype-independent immature secretion and subtype-dependent deficiency of a highly frequent, naturally occuring mutation of human hepatitis B core antigen" J. Virol. 73: 10122-10128

Yuan, T.T. und C. Shih (2000) "A frequent, naturally occuring mutation (P130T) of human hepatitis B virus core antigen is compensatory for immature secretion phenotype of another frequent variant (I97L)" J. Virol. 74: 4929-4932

Zheng, J., Schödel, F. und D.L. Peterson (1992) "The structure of hepadnaviral core antigens. Identification of free thiols and determination of the disulfide bonding pattern" J. Biol. Chem. 267: 9422-9428

Zhou, S. und D.N. Standring (1991) "Production of hepatitis B virus nucleocapsid like core particles in Xenopus oocytes" J. Virol. 66: 3086-3092

Zhou, S. und D.N. Standering (1992) "Hepatitis B virus capsids are assembled from core protein dimers" Proc. Natl. Acad. Sci. USA 89: 10046-10050

Zlotnick, A., Cheng, N., Stahl, S.J., Conway, J.F., Steven, A.C. und P.T. Wingfield (1997) "Localization of the C terminus of the assembly domain of hepatitis B virus capsid protein: implications for morphogenesis and organization of encapsidated RNA." Proc. Natl. Acad. Sci. USA 94: 9556-9561 


\section{DANKSAGUNGEN}

Herrn Prof. Dr. G. Hunsmann und Herrn Prof. Dr. O. Götze danke ich für die Bereitstellung meines Arbeitsplatzes in der Abteilung Virologie am Hygiene-Institut in Göttingen.

Herrn Prof. Dr. G. Gottschalk danke ich für Betreuung und Übernahme des Erstreferats, für das Korreferat bedanke ich mich bei Herrn PD Dr. H. Kolmar im Fachbereich Biologie der Georg-August-Universität Göttingen.

Mein besonderer Dank gilt Herrn PD Dr. Volker Bruß aus der Abteilung Virologie des Hygiene-Instituts für die Bereitstellung des interessanten Themas, für ein stetiges Interesse und die Unterstützung meiner Arbeit sowie für ein ganz besonderes Arbeitsverhältnis.

Ich danke Prof. Dr. D. Doenecke für die Aufnahme und Unterstützung durch das Graduiertenkolleg 521.

Meinen vielen Kollegen und Mitstreitern der Arbeitsgruppe, besonders Frau A. Koch danke ich für ein außergewöhnlich gutes Arbeitsklima und Hilfsbereitschaft.

Dank gilt auch meinen Eltern und meinen Schwiegereltern für die Unterstützung meiner Ziele und für das Vertrauen, das sie in mich setzen.

Ich danke meiner Frau Sabine, die mit mir am intensivsten die Höhen und Tiefen miterlebt hat, die mich jederzeit mit all Ihren Kräften unterstützt. 


\section{LEBENSLAUF}

Name:

Geburtstag und -ort:

Familienstand:

Staatsangehörigkeit:
Dirk Ponsel

07.09.1975 in Coburg

verheiratet

deutsch
1982-1986

1986-1992

1992-1995

1995-1997

$1997-2000$

Februar 1999

März 1999 bis

Januar 2000
Grundschule Fuldatal-Ihringshausen

Gymnasialzweig der Carl-Schomburg Schule in Kassel

gymnasiale Oberstufe der Goetheschule in Kassel

Grundstudium der Biologie an der Phillips-Universität Marburg und Vordiplom

Hauptstudium der Biologie an der Georg-August Universität Göttingen

mündliche Diplomprüfung im Hauptfach Genetik und den Nebenfächern Mikrobiologie und organische Chemie

Anfertigung der experimentellen Diplomarbeit am Institut für Mikrobiologie und Genetik, Abt. molekulare Genetik bei Herrn.

Prof. Dr. Fritz mit dem Thema „Untersuchungen zur Suppressionseffizienz eines in Escherichia coli exprimierten amber-Suppressor-tRNA/Aminoacyl-tRNA-Synthetasepaares von Saccheromyces cerevisiae“

März 2000 bis

September 2003
Anfertigung der vorliegenden Arbeit mit dem Thema „Kartierung von umhüllungsrelevanten Aminosäureresten auf dem Hepatitis B Virus Kapsid“ am Zentrum für Hygiene und Humangenetik, Abteilung Virologie bei Herrn HD Dr. V. Bruß 